ORNL/TM-12294/V3

OAK RIDGE

NATIONAL

LABORATORY

MARTIN MARIETTA
SCALE-4 Analysis of Pressurized Water Reactor Critical Configurations:

Volume 3 - Surry Unit 1 Cycle 2

S. M. Bowman

O. W. Hermann 
This report has been reproduced directly from the best available copy.

Available to DOE and DOE contractors from the Office of Scientific and Technical Information, P.O. Box 62, Oak Ridge, TN 37831; prices available from (615) 576-8401.

Available to the public from the National Technical Information Service, U.S. Department of Commerce, 5285 Port Royal Rd., Springfield, VA 22161.

This report was prepared as an account of work sponsored by an agency of the United States Government. Neither the United States nor any agency thereof, nor any of their employees, makes any warranty, express or implied, or assumes any legal liability or responsibility for the accuracy, completeness, or usefulness of any information, apparatus, product, or process disclosed, or represents that its use would not infringe privately owned rights. Reference herein to any specific commercial product, process, or service by trade name, trademark, manufacturer, or otherwise, does not necessarily constitute or imply its endorsement, recommendation, or favoring by the United States Government or any agency thereof. The views and opinions of authors expressed herein do not necessarily state or reflect those of the United States Government or any agency thereof. 
Computational Physics and Engineering Division

\title{
SCALE-4 ANALYSIS OF PRESSURIZED WATER REACTOR CRITICAL CONFIGURATIONS: VOLUME 3-SURRY UNIT 1 CYCLE 2
}

\author{
S. M. Bowman \\ O. W. Hermann
}

Date Completed: January 1995

Date Published: March 1995

\begin{abstract}
Prepared under the direction of
Sandia National Laboratories

under Memorandum Purchase Orders 66-0162 and AD-4072

with Oak Ridge National Laboratory
\end{abstract}

Prepared by the

OAK RIDGE NATIONAL LABORATORY

managed by

MARTIN MARIETTA ENERGY SYSTEMS, INC.

for the

U.S. DEPARTMENT OF ENERGY

under contract DE-AC05-84OR21400 



\section{CONTENTS}

Page

LIST OF FIGURES LIST OF TABLES

ABSTRACT

1. INTRODUCTION

2. OVERVIEW OF THE METHODOLOGY

2.1 FUEL ASSEMBLY GROUPS

2.2 DEPLETION CALCULATIONS

2.3 NUCLIDE CONCENTRATIONS FOR REACTOR CRITICALITY CALCULATIONS

2.4 CROSS-SECTION PROCESSING BY CROSS-SECTION SET

2.5 PREPARATION OF THE KENO V.a CORE MODEL .

3. PREPARATION OF THE SURRY 1 CYCLE 2 CORE MODEL $\ldots \ldots \ldots \ldots \ldots \ldots .13$

3.1 CORE DESCRIPTION $\ldots \ldots \ldots \ldots \ldots \ldots \ldots \ldots \ldots \ldots \ldots \ldots \ldots \ldots \ldots$

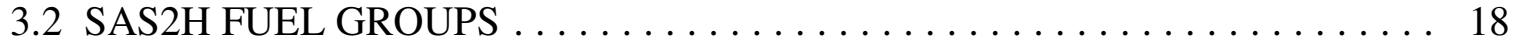

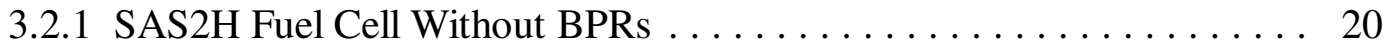

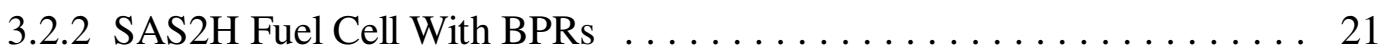

3.3 SIMILAR-BURNUP SUBGROUPING FOR CROSS-SECTION SETS $\ldots \ldots \ldots 25$

3.4 SAS2H DEPLETION CALCULATIONS $\ldots \ldots \ldots \ldots \ldots \ldots \ldots \ldots \ldots .25$

3.5 BURNUP-DEPENDENT INTERPOLATION OF ISOTOPICS $\ldots \ldots \ldots \ldots \ldots 30$

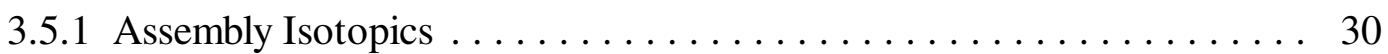

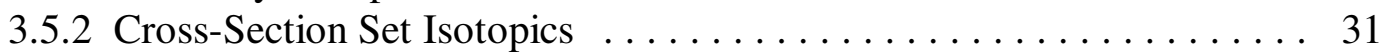

3.6 GENERATION OF CROSS SECTIONS USING CSASN $\ldots \ldots \ldots \ldots \ldots \ldots .31$

3.7 COMBINING CROSS-SECTION SET LIBRARIES USING WAX $\ldots \ldots \ldots \ldots 32$

3.8 VALIDATION OF CROSS-SECTION SET ASSUMPTIONS $\ldots \ldots \ldots \ldots \ldots 32$

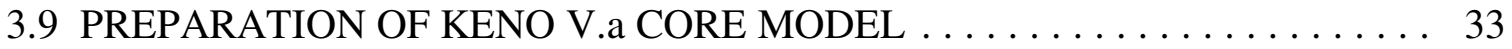

3.9 .1 KENO V.a Mixture Specifications $\ldots \ldots \ldots \ldots \ldots \ldots \ldots \ldots \ldots . \ldots \ldots$

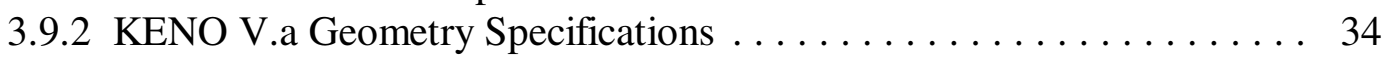

4. RESULTS AND CONCLUSIONS $\ldots \ldots \ldots \ldots \ldots \ldots \ldots \ldots \ldots \ldots \ldots \ldots \ldots \ldots \ldots$

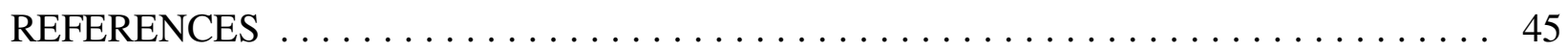

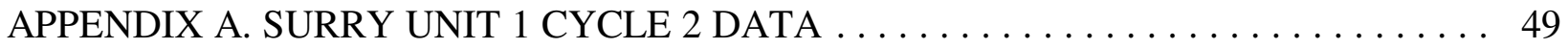

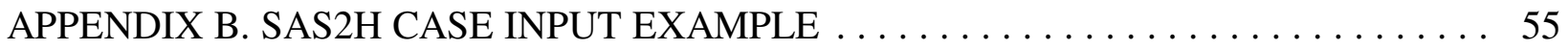

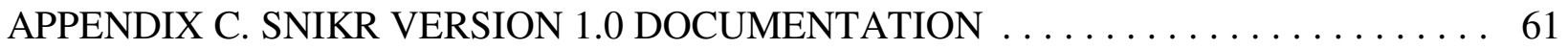

APPENDIX D. KENO V.a BOC MODEL SETUP INPUT EXAMPLES $\ldots \ldots \ldots \ldots \ldots .93$

APPENDIX E. KENO V.a EOC MODEL SETUP INPUT EXAMPLES $\ldots \ldots \ldots \ldots \ldots .129$ 


\section{LIST OF FIGURES}

Figure $\quad \underline{\text { Page }}$

1. Overview of the reactor critical calculation procedure. $\ldots \ldots \ldots \ldots \ldots$

2. SAS2H burnup model of assemblies within a fuel group $\ldots \ldots \ldots \ldots \ldots$

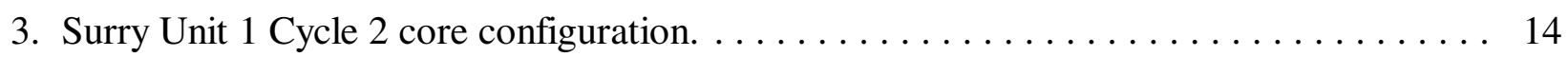

4. Fuel assembly lattice arrangements in Surry Unit 1 Cycle $2 \ldots \ldots \ldots \ldots$

5. Surry Unit 1 Cycle 2 burnable poison loading configuration $\ldots \ldots \ldots \ldots \ldots$

6. Surry Unit 1 eighth-core symmetric configuration $\ldots \ldots \ldots \ldots \ldots \ldots \ldots$

7. Full-core assembly positions and core baffle configuration $\ldots \ldots \ldots \ldots \ldots$

8. KENO V.a unit definitions based on component arrays $\ldots \ldots \ldots \ldots \ldots \ldots$

9. BOC, HZP eighth-core relative fission density distribution $\ldots \ldots \ldots \ldots \ldots \ldots$

10. EOC, HFP eighth-core relative fission density distribution $\ldots \ldots \ldots \ldots \ldots \ldots$

A.1. Surry Unit 1 Cycle 2 core loading pattern $\ldots \ldots \ldots \ldots \ldots \ldots \ldots \ldots$ 


\section{LIST OF TABLES}

\section{$\underline{\text { Table }}$}

Page

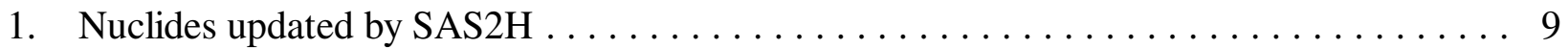

2. Set of fuel nuclides used in KENO V.a calculations $\ldots \ldots \ldots \ldots \ldots \ldots \ldots \ldots \ldots \ldots \ldots 11$

3. Surry Unit 1 Cycle 2 measured critical conditions at BOC and EOC $\ldots \ldots \ldots \ldots \ldots 17$

4. Surry PWR Unit 1 assembly design description $\ldots \ldots \ldots \ldots \ldots \ldots \ldots \ldots \ldots \ldots$

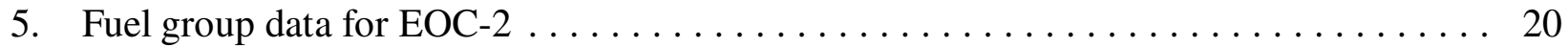

6. Initial uranium isotopic content of fresh fuel $\ldots \ldots \ldots \ldots \ldots \ldots \ldots \ldots \ldots$

7. Light-element masses used in SAS2H calculations $\ldots \ldots \ldots \ldots \ldots \ldots \ldots \ldots \ldots \ldots$

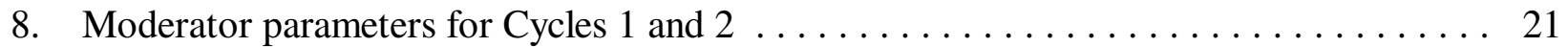

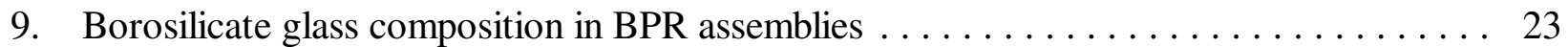

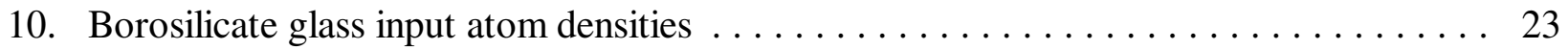

11. Number of BPRs and guide tubes in fuel groups with BPRs . . . . . . . . . . . 24

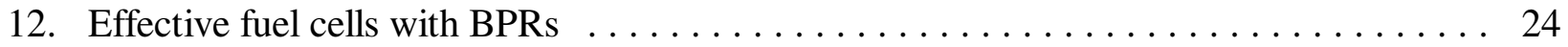

13. Fuel assembly data for eighth-core geometry $\ldots \ldots \ldots \ldots \ldots \ldots \ldots \ldots \ldots$

14. Cross-section sets for one-eighth core assemblies $\ldots \ldots \ldots \ldots \ldots \ldots \ldots \ldots \ldots \ldots \ldots$

15. Cross-section sets for Surry Unit 1 Cycle 2 BOC $\ldots \ldots \ldots \ldots \ldots \ldots \ldots \ldots$

16. Cross-section sets for Surry Unit 1 Cycle 2 EOC $\ldots \ldots \ldots \ldots \ldots \ldots \ldots \ldots \ldots$

17. SAS2H operating history data by fuel group and cycle $\ldots \ldots \ldots \ldots \ldots \ldots \ldots$

18. $\mathrm{k}_{\infty}$ comparison for validation of cross-section methodology $\ldots \ldots \ldots \ldots \ldots \ldots$

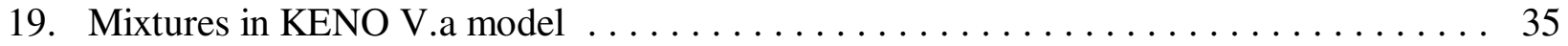

20. Unit numbers used in Surry KENO V.a core model . . . . . . . . . . . . . . . . . 39

21. KENO V.a calculated results for Surry Unit 1 Cycle $2 \ldots \ldots \ldots \ldots \ldots \ldots \ldots \ldots \ldots \ldots$

22. Range of conditions for Surry reactor criticals $\ldots \ldots \ldots \ldots \ldots \ldots \ldots \ldots \ldots \ldots \ldots$

A.1. Fuel assembly burnups at BOC and EOC for Surry Unit 1 Cycle $2 \ldots \ldots \ldots \ldots 2$

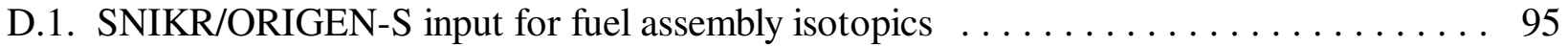

D.2. SNIKR/ORIGEN-S input for cross-section set average isotopics $\ldots \ldots \ldots \ldots \ldots \ldots$. . . . 97

D.3. CSASN input for cross-section sets with important actinides only . . . . . . . . . . . 99

D.4. CSASN input for cross-section set $4 \ldots \ldots \ldots \ldots \ldots \ldots \ldots \ldots \ldots$

D.5. WAX input for cross-section library generation $\ldots \ldots \ldots \ldots \ldots \ldots \ldots \ldots \ldots$

D.6. XSDRNPM input for eighth-core-assembly location $1 \ldots \ldots \ldots \ldots \ldots \ldots$

D.7. CSAS1X input for eighth-core assembly location $1 \ldots \ldots \ldots \ldots$. . . . . . . . . 104

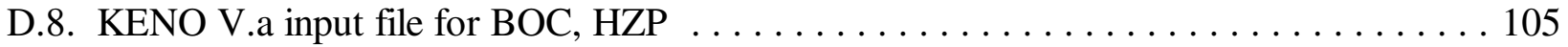

E.1. SNIKR/ORIGEN-S input for fuel assembly isotopics $\ldots \ldots \ldots \ldots \ldots \ldots \ldots \ldots \ldots 131$

E.2. SNIKR/ORIGEN-S input for BP isotopics $\ldots \ldots \ldots \ldots \ldots \ldots \ldots \ldots \ldots \ldots \ldots \ldots$

E.3. CSASN input for cross-section sets with important actinides only . . . . . . . . . 133

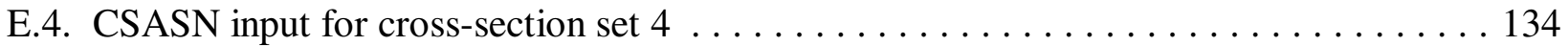

E.5. WAX input for cross-section-library generation $\ldots \ldots \ldots \ldots \ldots \ldots \ldots \ldots \ldots$

E.6. XSDRNPM input for eighth-core-assembly location $9 \ldots \ldots \ldots \ldots \ldots \ldots \ldots$

E.7. CSAS1X input for eighth-core-assembly location $9 \ldots \ldots \ldots \ldots \ldots \ldots \ldots$

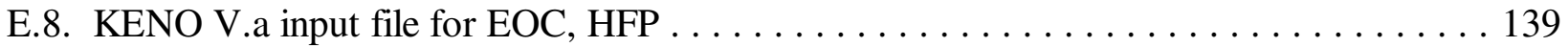




\begin{abstract}
The requirements of ANSI/ANS 8.1 specify that calculational methods for away-from-reactor criticality safety analyses be validated against experimental measurements. If credit for the negative reactivity of the depleted (or spent) fuel isotopics is desired, it is necessary to benchmark computational methods against spent fuel critical configurations. This report summarizes a portion of the ongoing effort to benchmark away-from-reactor criticality analysis methods using selected critical configurations from commercial pressurized-water reactors.

The analysis methodology selected for all the calculations in this report is based on the codes and data provided in the SCALE-4 code system. The isotopic densities for the spent fuel assemblies in the critical configurations were calculated using the SAS2H analytical sequence of the SCALE-4 system. The sources of data and the procedures for deriving SAS2H input parameters are described in detail. The SNIKR code module was used to extract the necessary isotopic densities from the $\mathrm{SAS} 2 \mathrm{H}$ results and to provide the data in the format required by the SCALE criticality analysis modules. The CSASN analytical sequence in SCALE-4 was used to perform resonance processing of the cross sections. The KENO V.a module of SCALE-4 was used to calculate the effective multiplication factor $\left(\mathrm{k}_{\mathrm{eff}}\right)$ of each case. The SCALE-4 27-group burnup library containing ENDF/B-IV (actinides) and ENDF/B-V (fission products) data was used for all the calculations.

This volume of the report documents the SCALE system analysis of two reactor critical configurations for Surry Unit 1 Cycle 2. This unit and cycle were chosen for a previous analysis using a different methodology because detailed isotopics from multidimensional reactor calculations were available from the Virginia Power Company. These data permitted a direct comparison of criticality calculations using the utility-calculated isotopics with those using the isotopics generated by the SCALE-4 SAS2H sequence. These reactor critical benchmarks have been reanalyzed using the methodology described above. The two benchmark critical calculations were the beginning-of-cycle (BOC) startup at hot, zero-power (HZP) and an end-of-cycle (EOC) critical at hot, full-power (HFP) critical conditions. These calculations were used to check for consistency in the calculated results for different burnup, downtime, temperature, xenon, and boron conditions. The $\mathrm{k}_{\text {eff }}$ results were 1.0014 and 1.0113, respectively, with a standard deviation of 0.0005 .
\end{abstract}




\section{INTRODUCTION}

In the past, criticality analysis of pressurized-water-reactor (PWR) fuel in storage or transport has assumed that the fuel is fresh with the maximum allowable initial enrichment. This assumption has led to the design of widely spaced and/or highly poisoned storage and transport arrays. If credit is assumed for fuel burnup, more compact and economical arrays can be designed. Such reliance on the reduced reactivity of spent fuel for criticality control is referred to as "burnup credit." If burnup credit is applied in the design of a cask for use in the transport of spent light-water-reactor (LWR) fuel to a repository, a significant reduction both in the cost of transport and in the risk to the public can be realized ${ }^{1}$ These benefits caused the U.S. Department of Energy (DOE) to initiate a program to investigate the technical issues associated with burnup credit in spent fuel cask design. These efforts have been led by Sandia National Laboratories (SNL) and carried out as part of the Cask Systems Development Program within the Office of Civilian Radioactive Waste Management. This four-volume report documents work performed at Oak Ridge National Laboratory (ORNL) as part of a larger effort to demonstrate an acceptable approach for validating computational tools to be used in burnup credit cask design.

The computational tools of interest for burnup credit cask design are initially those currently used and accepted for spent fuel characterization (prediction of isotopics) and criticality safety (prediction of the effective multiplication factor, $\mathrm{k}_{\mathrm{eff}}$ ) in away-from-reactor (AFR) applications. The criticality analysis tools accepted for fresh fuel cask design have typically been validated per the requirements of the ANSI/ANS-8.1 criticality safety standard2 (i.e., comparison against experimental data). Numerous critical experiments for fresh PWR-type fuel in storage and transport configurations exist and can be used as part of a validation data base. However, there are no critical experiments with burned PWR-type fuel in storage and transport configurations that can be directly used to extend the data base to the realm of burned fuel. Thus, as part of the effort to extend the validation of existing criticality analysis tools to the domain of burned fuel, it was decided to investigate the performance of AFR analysis methods in the prediction of measured reactor critical configurations. Even though elements of a reactor critical analysis do not directly correspond to analyses of spent fuel assemblies in transportation and storage casks (e.g., elevated temperatures in reactor configurations or poison plates in cask designs), comparison against measured critical configurations can be used to validate aspects of spent fuel cask configurations that are not addressed in other experiments (i.e., fission-product interactions and the prediction of time-dependent actinide and fission-product inventories). Reactor critical configurations contain a diverse range of nuclides, including fissile and fertile actinides, fission products, and activation products. Thus, nuclear reactor core criticals can be used to test an analysis methodology's ability to generate accurate burned fuel isotopics and handle the reactivity effects of complex heterogeneous systems containing burned fuel.

This report describes the data and procedures used to predict the multiplication factor for several measured critical core configurations using a select set of AFR analysis codes. The analyses were performed for precise state points at beginning of cycle (BOC) (mixture of fresh and burned fuel) and at measured state points throughout the cycle depletion (all burned fuel). Self-consistency among the reactor criticals in the prediction of $\mathrm{k}_{\text {eff }}$ will allow the determination of the bias of the approach taken in representing the effect of those materials not present in fresh fuel. 
To date, the SCALE code system ${ }^{3}$ developed at ORNL has been the primary computational tool used by DOE to investigate technical issues related to burnup credit ${ }^{4}$ SCALE is a wellestablished code system that has been widely used in AFR applications for spent fuel characterization via the SAS2H/ORIGEN-S analysis sequence 5 and criticality safety analyses via the CSAS/KENO V.a analysis sequence ${ }^{6}$ The isotopic composition of the spent fuel is derived from a SAS2H/ORIGEN-S calculation that simulates two-dimensional (2-D) effects in a one-dimensional(1-D) model of an LWR fuel assembly. The depletion model is a spatially independent point model using cross sections and neutron flux parameters derived from the 1-D fuel assembly model. The KENO V.a Monte Carlo $\operatorname{code}^{7}$ is used to calculate the neutron multiplication factor for complex multidimensional systems. KENO V.a has a large degree of flexibility in its geometrical modeling capabilities which enables spent fuel arrays and container geometries to be modeled in explicit detail. The SCALE-4 27-group burnup library containing ENDF/B-IV (actinides) and ENDF/B-V (fission products) data was used for all calculations.

Early efforts to analyze reactor criticals 8 using the SCALE modules concentrated on using utility-generated isotopic data, although some analyses were performed using isotopics calculated with SAS2H. Based on this initial work, a consistent SCALE-based analysis methodology that simplifies both the data requirements and the calculational procedure was developed. The criteria used to select the reactor critical configurations were (1) applicability to the PWR fuel to be used in burnup credit cask design (e.g., long downtimes for decay of short-lived isotopes, large percentages of burned fuel in the configuration), the need to verify consistency in calculated results for different reactor conditions, and the need to provide a comparison with the results of ref. 5 . Acceptable performance of the SCALE system in the prediction of $\mathrm{k}_{\text {eff }}$ will be judged relative to established SCALE performance for fresh fuel systems; if agreement is seen within the range typical for fresh fuel systems, then it will be concluded that the methodology described herein is valid in terms of its treatment of depletion and decay calculations and fission-product interactions, within the range of application defined by the reactor conditions.

The purpose of this volume of the report is to describe the reanalysis of two reactor critical configurations from Virginia Power's Surry Unit 1 Cycle 2 that were previously analyzed in ref. 8. These cases were originally selected because of the availability of the operating data and the threedimensional (3-D) calculated nuclide density distributions from the utility's reactor physics calculations. The revised methodology was first validated by comparison to three reactor critical configurations from Tennessee Valley Authority's Sequoyah Unit 2 Cycle 3 in Vol. 2 of this report. Differences of approximately 1 to $2.5 \% \Delta \mathrm{k}$ were observed between the results of the original and revised methodologies. To investigate these differences further, the Surry reactor criticals have been reanalyzed using the revised SCALE methodology. The two benchmark critical calculations were the BOC startup at HZP and EOC operation at HFP critical conditions. These calculations were used to check for consistency in the calculated results for different burnup, downtime, temperature, soluble boron, and xenon conditions.

Section 2 of this volume presents an overview of the methodology employed in the reactor critical analyses. Section 3 provides the details of the analysis performed for Surry 1 Cycle 2. The results and conclusions are discussed in Sect. 4. 


\section{OVERVIEW OF THE METHODOLOGY}

An essential part of any analysis validation effort is to use the same codes, input options, and technical approach for the validation study as that used for the application. To this end, a straightforward calculational strategy was established that minimizes the data required to characterize the spent fuel and is appropriate for use by a cask designer performing criticality analysis for spent fuel assemblies.

The methodology applied in reactor critical analyses can be broken into five steps: (1) grouping of fuel assemblies into similar-content groups and similar-burnup subgroups; (2) calculation of burnup-dependent isotopics for each group; (3) interpolation of decay calculations from results of the previous step to obtain both individual assembly and subgroup isotopics; (4) cross-section processing based on subgroup isotopics; and (5) preparation of a KENO V.a model based on the actual core geometry, individual assembly isotopics, and subgroup-evaluated cross sections. The model developed in step 5 is used to calculate the effective multiplication factor, $\mathrm{k}_{\text {eff }}$, for the reactor.

Figure 1 provides a graphical overview of these steps, showing the relationships between the data and codes used in each stage of the calculation. The first step shown in the figure represents the process of collecting assembly information from reactor documentation. Eighth-core symmetry is assumed to reduce the number of unique assemblies models, such that the burnup of each assembly in an eighth-core segment represents the average burnup of all assemblies located in the corresponding symmetric position across the core. Using the reactor information, "groups" of assemblies are identified which are of cognate background (i.e., same initial loading and burn cycles). These assembly groups are then further categorized into "subgroups" consisting of assemblies within a group with similar ( $\pm 2 \mathrm{GWd} / \mathrm{MTU})$ burnups.

The second step shown in the figure involves the calculation of isotopic contents using the decay and depletion steps of the SAS2H calculational sequence of SCALE. Calculations are performed for each assembly group based on the initial fresh fuel content and operating history of the group. Output consists of calculated isotopic contents for each of a number of user-specified timesteps.

In step three, the SNIKR code package (not a part of the SCALE system) is used to interpolate between isotopics for appropriate timesteps in order to obtain the assembly-specific isotopic contents for each assembly to be used in the KENO V.a core model. (SNIKR is a simple tool used to automate the task of extracting, interpolating, and formatting data; however, this process can be performed manually.) SNIKR is also used to calculate the isotopics for the average burnup of each assembly subgroup.

The results of step three are used in step four to create fuel pin models based on the average composition of an assembly subgroup; the CSASN sequence in SCALE is then used to calculate the problem dependent group-weighted cross sections for each subgroup. the SCALE WAX module is then used to combine all subgroup-based cross sections into a single working library, where crosssection identifiers are assigned such that each numeric identifier indicates both a specific isotope and the subgroup upon which it was based. 


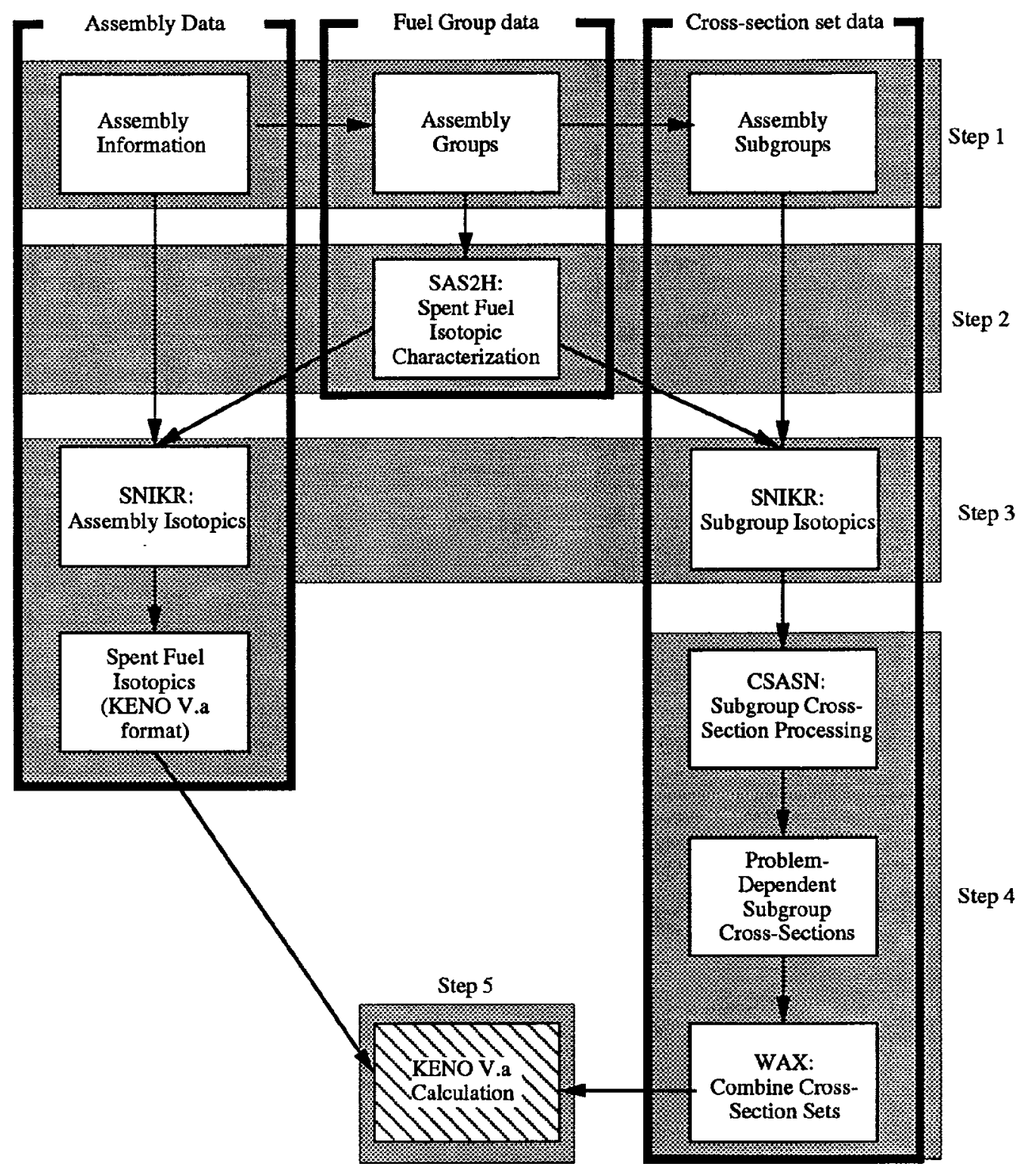

Fig. 1. Overview of the reactor critical calculation procedure. 
Finally, in step five a KENO V.a model is created based on the core geometry, again assuming eighth-core symmetry. Thus, while a full-core model is prepared, each eighth-core segment of the core is identical in composition to the other eighth-core segments. (A full-core model in KENO V.a is more computationally efficient than an eighth-core model with reflective boundary conditions.) Fuel assemblies are assumed to be uniform in composition (all fuel pins are comprised of the same material), and isotopics are obtained from the burnup-specific results obtained in step 3. Assembly isotopes are assigned cross-section identifiers corresponding to the appropriate subgroup-based cross sections derived in step 4. Remaining core information is obtained from the reactor documentation. Calculations are then performed to determine the value of $\mathrm{k}_{\mathrm{eff}}$ for the reactor model and to verify that the solution has converged.

The specifics of each of the steps described above are discussed in detail in each of the following sections.

\subsection{FUEL ASSEMBLY GROUPS}

Since many assemblies in a reactor begin with identical initial compositions and experience simultaneous operating histories, these similar fuel assemblies can be collected effectively into groups, with one depletion calculation performed for each group. It is assumed that at a given burnup, all assemblies within a group have the same isotopic content. If the isotopic content of a group is known as a function of burnup, then one can interpolate to obtain the specific isotopics for a given assembly burnup. This interpolation is discussed further in Sect. 2.3.

A minimum granularity for grouping is to collect fuel assemblies by reactor fuel batch. In the nomenclature generally applied by commercial PWR core designers, a fuel batch is typically comprised of a single enrichment fuel, all loaded at the same time, and all residing in-core for the same fuel cycles. Three fuel batches (i.e., enrichments) are usually present in the first operating cycle of a reactor. These batches are typically designated by the numbers 1, 2, and 3. Prior to each subsequent cycle of operation, one new batch of fuel is usually added and some of the depleted fuel assemblies are removed. Each new batch of fuel is assigned a number unique to that reactor. If the new fuel assemblies to be loaded consist of more than one enrichment, they may be assigned as a "split batch" using the same number with a different letter appended to each enrichment. For example, if two enrichments were to be added to Cycle 2, the fuel assemblies of one enrichment would be designated as batch 4A, and those of the other enrichment would be designated as batch 4B. Hence, if a given batch of assemblies has experienced identical operating periods, downtimes, and roughly the same power history, the batch meets the minimum requirements for a calculational fuel group. However, within a given fuel batch, additional fuel groups (i.e., separate depletion calculations) may be required when absorber materials [i.e., burnable poison rods (BPRs) or control rods] are present in certain assemblies within the fuel batch.

As discussed, within a fuel group it is possible to interpolate between a series of burnups to determine the isotopic concentrations corresponding to a specific burnup. This interpolation procedure can be used to calculate the contents of each individual assembly. Based on these assembly isotopics, it is possible to generate a content-specific cross-section set for each assembly. However, since nuclide cross sections vary slowly with burnup (after the initial startup of approximately $150 \mathrm{MWd} / \mathrm{MTU})$, the analysis methodology can be accurately simplified by preparing problem- 
dependent cross sections for a set of similar assemblies with similar burnups. Unfortunately, due to specific power variations related to the assembly locations in the core, it is possible to have a relatively wide range of burnups within a single fuel group. Thus it may be necessary to divide fuel groups into subgroups or cross-section sets based on burnup such that all assemblies included in a cross-section set are within a limited burnup range; the number of cross-section sets will depend on the range of burnups contained in the fuel group. Calculations reported in Sect. 3.8 of this report indicate that cross-section sets with burnup ranges of no more than $2 \mathrm{GWd} / \mathrm{MTU}$ can be adequately represented by the average burnup value within the cross-section set.

\subsection{DEPLETION CALCULATIONS}

Depletion calculations were performed using the SAS2 $\mathrm{H}^{5}$ sequence of the SCALE- 4 code system and the 27-group burnup library. The SAS2H sequence invokes the ORIGEN-S? code to perform depletion and decay calculations. The SAS2H procedure uses a 1-D, two-part spectrum calculation (part 1 is a pin-cell model, part 2 is an assembly model) at selected times in the irradiation history to generate burnup-dependent cross sections based on the given design and operating parameters. At the end of each burnup step, cross sections for default and any user-specified isotopes are reevaluated based on the new isotopic composition. The purpose of these calculations is to predict the isotopic content of each fuel group as a function of its operating history. For fuel groups comprised of fresh (unburned) fuel at the time of the critical measurements, SAS2H calculations are not necessary; the isotopic content is based on that of the fresh fuel specifications.

Although it is necessary to model the presence of BPRs for the cycle for which the criticality calculation is to be performed, previous studie ${ }^{[1,1]}$ have shown that the history of the assembly with respect to the insertion and removal of BPRs in earlier reactor cycles is small enough to be neglected $(<1 \% \Delta \mathrm{k} / \mathrm{k})$. To model the influence of the BPRs in the cycle of interest, an effective cell is derived. This effective cell conserves the mass of the nuclides comprising the BPRs, guide tube, and fuel rods. In this effective cell, the densities of the isotopes remain unchanged, but the rod diameters of the glass and stainless steel in the BPRs are modified appropriately for the 1-D assembly model required by SAS2H.

Since within a fuel group it is assumed that isotopic content is a function only of burnup, it is possible to calculate the content of the fuel at a given burnup by interpolation between SAS2H/ORIGEN-S isotopics provided at each burnup step. The manner of interpolation is discussed in the following subsection. SAS2H provides the capability to obtain the isotopic composition of a fuel at specified burnup intervals given the initial composition of the fuel, clad, and moderator, design parameters of the fuel rod and lattice, and power history. In order to provide sufficient points for interpolation, the burnup history was divided into equal intervals of no more than $5 \mathrm{GWd} / \mathrm{MTU}$. (This interval should not be confused with the 2-GWd/MTU interval used to establish assembly subgroups. The 5-GWd/MTU interval represents an interpolation range over which isotopic concentrations are assumed to vary smoothly.) The fuel groups were depleted at least 1.2 times the maximum burnup $\left(\mathrm{B}_{\max }\right)$ of the fuel group. Note that it is generally sufficient to calculate burnups out to the maximum burnup in a group, as this will bound all burnups in the group. A value of $1.2 * \mathrm{~B}_{\max }$ was used to allow for the capability of modeling axial burnup variations where volume-averaged center region burnups 
may be up to 1.2 times larger than the assembly average. However, axial burnup variations are not included in the models presented in this report.

To make it possible to interpolate between burnup steps and to account for downtime between cycles, a simplification is made in the burnup model. Since the burnup actually accumulated during each cycle varies for each fuel assembly in a group, the downtime was split and applied at the end of each burnup interval. This practice ensures that the spent fuel isotopics for all fuel assemblies contain the impact of the reactor cycle downtime when interpolation on burnup is performed. The ratio of uptime to downtime for each operating cycle was used to determine the downtime for each burnup interval. Average values for specific power were computed from the fuel group average burnups and the total uptime for the cycle. The average soluble boron concentrations were based on boron letdown curves for each operating cycle. Isotopics for assembly-specific burnups may then be obtained via interpolation between calculated isotopics at the end of each burnup interval (prior to downtime). This approach is illustrated in Fig. 2. The top portion of the picture shows the "actual" burnup histories for two hypothetical assemblies in a fuel group. Note that in this example the number of cycles and downtimes are the same, but that burnup in each assembly is different within each cycle. The lower portion of the figure demonstrates how the burnup of each assembly is represented in a SAS2H depletion, using a single calculation to represent the entire fuel group. Each cycle is broken down into multiple burnup intervals, each followed by a downtime (for the first two cycles). The final cycle is calculated with a sufficient number of burnup intervals to exceed the maximum burnup (31 MWd/MTU in assembly A of Fig. 2) by $20 \%$. The isotopics are then available at fixed time intervals, from which interpolation can be performed for assembly-specific burnups. Note that the burnup in each of the first two cycles is selected to represent average cycle burnups for the group. Any downtime immediately before the reactor critical conditions was not included in the SAS2H depletion, but was explicitly modeled as described in Sect. 2.3.

As discussed earlier, group-weighted cross sections are calculated as a function of burnup within the SAS2H sequence using flux weighting performed by XSDRNPM for each specified burnup step. Cross sections are updated for a default set of isotopes built into the SAS2H sequence, plus any additional nuclides specified by the user. Table 1 shows the default set plus 44 additional actinides and fission products specified for reactor depletion cases. Also included is oxygen, which is present in significant quanties in $\mathrm{UO}_{2}$ fuel. These nuclides represent a combination of the most important nuclides for burnup credit calculations and for reactor physics calculations. The selection of burnup credit nuclides is based availability of experimentally measured isotopic concentrations and on sensitivity studies performed for a large number of nuclides under various spent fuel transportation/storage conditions, as described in ref. 12. The reactor physics nuclides are additional isotopes that are not important in a transportation sense, but have been determined to be important for depletion, decay, and criticality calculations under reactor operating conditions (e.g., ${ }^{135}$ Xe builds in rapidly during reactor operation, but decays away with a 9.1-h half-life, and is therefore unimportant in five-year-cooled spent fuel). These nuclides were identified in earlier work. 10,13

Any additional cross sections required for depletion calculations are obtained from the more than 1000 nuclides available within the ORIGEN-S 1-group LWR library and are adjusted with burnup using the ORIGEN-S spectral parameters (THERM, RES, and FAST) ${ }^{9}$ calculated using fluxes calculated by XSDRNPM. The ORIGEN-S 1-group LWR library available in SCALE-4 has been 


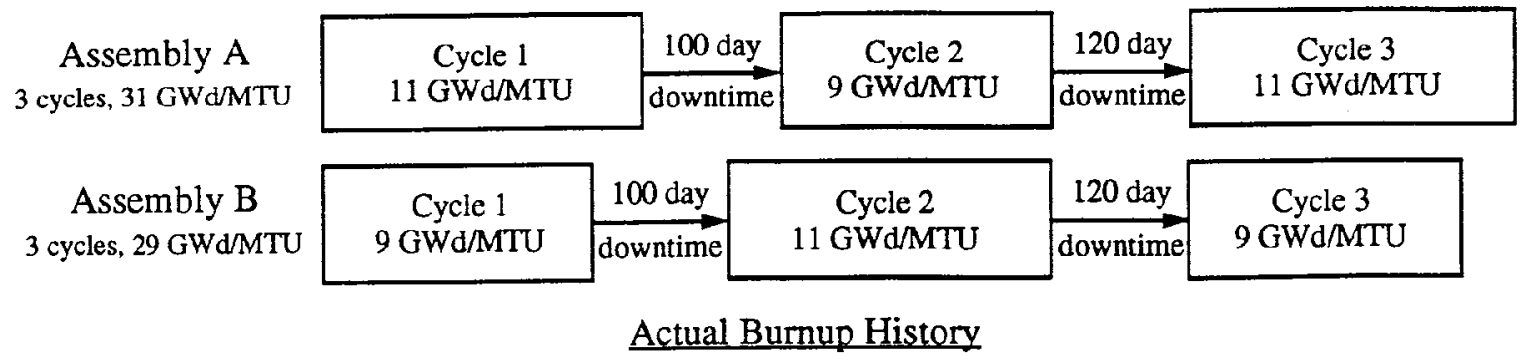

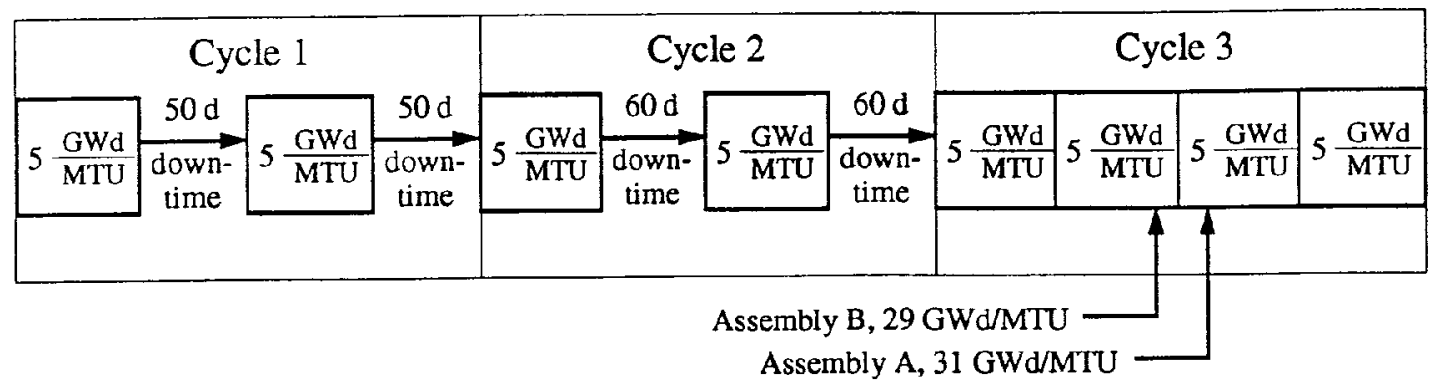

Fig. 2. SAS2H burnup model of assemblies within a fuel group. 
Table 1. Nuclides updated by SAS2H

\begin{tabular}{lllll}
\hline${ }^{234} \mathrm{U}^{a}$ & ${ }^{243} \mathrm{Am}^{a}$ & ${ }^{94} \mathrm{Nb}$ & ${ }^{132} \mathrm{Xe}$ & ${ }^{145} \mathrm{Nd}$ \\
${ }^{235} \mathrm{U}^{a}$ & ${ }^{242} \mathrm{Cm}^{a}$ & ${ }^{16} \mathrm{O}^{b}$ & ${ }^{135} \mathrm{Xe}^{a}$ & ${ }^{147} \mathrm{Nd}$ \\
${ }^{236} \mathrm{U}^{a}$ & ${ }^{243} \mathrm{Cm}^{a}$ & ${ }^{99} \mathrm{Tc}$ & ${ }^{136} \mathrm{Xe}$ & ${ }^{147} \mathrm{Pm}$ \\
${ }^{238} \mathrm{U}^{a}$ & ${ }^{244} \mathrm{Cm}^{a}$ & ${ }^{101} \mathrm{Ru}$ & ${ }^{133} \mathrm{Cs}^{a}$ & ${ }^{148} \mathrm{Pm}$ \\
${ }^{23} \mathrm{~Np}^{a}$ & ${ }^{83} \mathrm{Kr}$ & ${ }^{106} \mathrm{Ru}$ & ${ }^{134} \mathrm{Cs}^{{ }^{147} \mathrm{Sm}}$ \\
${ }^{238} \mathrm{Pu}^{a}$ & ${ }^{85} \mathrm{Kr}$ & ${ }^{103} \mathrm{Rh}$ & ${ }^{135} \mathrm{Cs}$ & ${ }^{149} \mathrm{Sm}$ \\
${ }^{239} \mathrm{Pu}^{a}$ & ${ }^{90} \mathrm{Sr}$ & ${ }^{105} \mathrm{Rh}$ & ${ }^{137} \mathrm{Cs}$ & ${ }^{150} \mathrm{Sm}$ \\
${ }^{241} \mathrm{Pu}^{a}$ & ${ }^{89} \mathrm{Y}$ & ${ }^{105} \mathrm{Pd}$ & ${ }^{136} \mathrm{Ba}$ & ${ }^{151} \mathrm{Sm}$ \\
${ }^{24} \mathrm{Mo}$ & ${ }^{108} \mathrm{Pd}$ & ${ }^{139} \mathrm{La}$ & ${ }^{152} \mathrm{Sm}$ \\
${ }^{241} \mathrm{Am}^{a}$ & ${ }^{93} \mathrm{Zr}$ & ${ }^{109} \mathrm{Ag}$ & ${ }^{144} \mathrm{Ce}$ & ${ }^{153} \mathrm{Eu}$ \\
${ }^{242 m} \mathrm{Am}^{a}$ & ${ }^{124} \mathrm{Zr}$ & ${ }^{131} \mathrm{Xb}$ & ${ }^{141} \mathrm{Pr}$ & ${ }^{154} \mathrm{Eu}$ \\
& & & ${ }^{143} \mathrm{Pr}$ & ${ }^{155} \mathrm{Eu}$ \\
\hline
\end{tabular}

${ }^{a}$ Automatically updated by SAS2H.

${ }^{b}$ Not an actinide or fission product, but present in $\mathrm{UO}_{2}$ fuel.

updated to use cross sections from the SCALE-4 27-group burnup library for all 193 nuclides in that library, by extracting 1-group cross sections from the output of a low-burnup LWR-type fuel model using all burnup library nuclides as input.

Note that ORIGEN-S tracks all decay chains and does not account for the loss of volatile isotopes; however, this fact is not felt to have a significant effect on isotopic calculations.

\subsection{NUCLIDE CONCENTRATIONS FOR REACTOR CRITICALITY CALCULATIONS}

As has been indicated in previous sections, the isotopic content may be determined for each assembly or cross-section set by interpolating between burnups for which SAS2H/ ORIGEN-S depletion calculations have been performed, based on the final burnup of the fuel. The nuclide concentrations output at this point then represents a composition prior to shutdown or discharge. For a criticality condition obtained after the shutdown of the last cycle, it is necessary to perform decay calculations to account for the change in composition caused by radioactive decay during the downtime prior to criticality.

The actual number densities used in the criticality calculations are derived from the SAS2H calculation for a given fuel batch using a newly developed interface module, SAS2H Nuclide Inventories for KENO Runs (SNIKR). This module was developed to enable the user to interpolate number densities from a SAS2H calculation as a function of burnup and to perform the necessary decay calculations to model cooling time for use in spent fuel critical calculations. SNIKR has not been incorporated into SCALE at this time. Thus, input descriptions and code listings have been included in Appendix C. 
The current version of SNIKR has been written to be executed as a sequence of computational routines. In the first phase, SNIKR1, burnup-dependent nuclide inventories are read from a dataset produced from a SAS2H calculation. SNIKR1 uses a Lagrangian interpolation scheme to calculate nuclide concentrations for a specified burnup. In the Lagrangian interpolation scheme, a polynomial of degree 1 less than the number of data points to be fit is used to represent the number density for each nuclide as a function of burnup. Comparisons have been made against results using nuclide concentrations calculated directly from SAS2H for a specified burnup to examine the effect of the interpolation procedure on pin-cell $\mathrm{k}_{\infty}$ (i.e., 1-D infinite-lattice calculation) values. The results of these comparisons indicated agreement to within $0.1 \% \Delta \mathrm{k}$ in the $\mathrm{k}_{\infty}$ values calculated using isotopics derived from the two methods.

SNIKR1 then sets up the input needed to decay these burnup-specific isotopics to the requested cooling time using the ORIGEN-S point-depletion code. The second phase of SNIKR executes the ORIGEN-S module in the SCALE code system. Phase three, SNIKR3, reads the number densities produced by ORIGEN-S for the requested cooling time and extracts the nuclides to be used in the depleted fuel for the burnup credit criticality analysis. Number densities for these nuclides are then written to output files in the SCALE standard composition input format and the KENO V.a mixing table data format for use in CSASN and KENO V.a calculations, respectively. Typically, the term "SNIKR" is used to refer to the three-step sequence of calculations described above.

SNIKR extracts concentrations for the set of nuclides specified by the user. The set of nuclides selected for the reactor critical benchmark calculations consists of the 48 nuclides listed in Table 2. These nuclides are a subset of those in Table 1, with the exception of ${ }^{103} \mathrm{Ru},{ }^{135} \mathrm{I},{ }^{148} \mathrm{Nd}$, and

${ }^{149} \mathrm{Pm}$. The cross sections of these four nuclides are small enough or change slowly enough with burnup that omitting them from the cross-section update in SAS2H has a negligible effect and are therefore not needed in the SAS2H calculation. In addition to the 25 nuclides selected for use in burnup credit analysis in ref. 4, the list in Table 2 includes the other nuclides discussed in an earlier burnup credit feasibility study, ${ }^{1}$ together with nuclides modeled explicitly in the burnup credit work of refs. 10 and 13.

\subsection{CROSS-SECTION PROCESSING BY CROSS-SECTION SET}

The $\mathrm{CSASN}^{6}$ sequence of the SCALE system is used to compute problem-dependent fuel pin cross sections based on the isotopic content and geometry of a lattice fuel cell. Based on a 1-D fuel pin model, CSASN invokes BONAMI-S ${ }^{14}$ to perform resonance shielding calculations using Bondarenko factors, followed by NITAWL-II $^{15}$ calculations to perform resolved resonance range cross-section processing using the Nordheim Integral Treatment.

CSASN cross-section processing is applied only to cross-section set-averaged nuclide concentrations. As discussed earlier in Sect. 2.1, effective cross sections are not strongly coupled to burnup; hence it is sufficient to compute cross sections for the average burnup of a cross-section set, provided the range of burnups in the cross-section set is not too large (less than $2 \mathrm{GWd} / \mathrm{MTU}$ ). Nuclide concentrations for use in the CSASN calculation are provided in the SCALE standard composition format in the output from the SNIKR cross-section set calculations. 
Table 2. Set of fuel nuclides used in KENO V.a calculations

\begin{tabular}{ccc}
\hline${ }^{234} \mathrm{U}^{a}$ & ${ }^{83} \mathrm{Kr}^{d}$ & ${ }^{141} \mathrm{Pr}^{b}$ \\
${ }^{235} \mathrm{U}^{a}$ & ${ }^{93} \mathrm{Zr}^{b}$ & ${ }^{143} \mathrm{Nd}^{a}$ \\
${ }^{236} \mathrm{U}^{a}$ & ${ }^{95} \mathrm{Mo}^{a}$ & ${ }^{145} \mathrm{Nd}^{a}$ \\
${ }^{238} \mathrm{U}^{a}$ & ${ }^{99} \mathrm{Tc}^{a}$ & ${ }^{147} \mathrm{Nd}^{c}$ \\
${ }^{237} \mathrm{~Np}^{b}$ & ${ }^{101} \mathrm{Ru}^{b}$ & ${ }^{148} \mathrm{Nd}^{c}$ \\
${ }^{238} \mathrm{Pu}^{a}$ & ${ }^{103} \mathrm{Ru}^{c}$ & ${ }^{147} \mathrm{Pm}^{b}$ \\
${ }^{239} \mathrm{Pu}^{a}$ & ${ }^{103} \mathrm{Rh}^{a}$ & ${ }^{148} \mathrm{Pm}^{c}$ \\
${ }^{240} \mathrm{Pu}^{a}$ & ${ }^{105} \mathrm{Rh}^{c}$ & ${ }^{149} \mathrm{Pm}^{c}$ \\
${ }^{241} \mathrm{Pu}^{a}$ & ${ }^{105} \mathrm{Pd}^{b}$ & ${ }^{147} \mathrm{Sm}^{a}$ \\
${ }^{242} \mathrm{Pu}^{a}$ & ${ }^{108} \mathrm{Pd}^{b}$ & ${ }^{149} \mathrm{Sm}^{a}$ \\
${ }^{241} \mathrm{Am}^{a}$ & ${ }^{109} \mathrm{Ag}^{b}$ & ${ }^{150} \mathrm{Sm}^{a}$ \\
${ }^{243} \mathrm{Am}^{b}$ & ${ }^{135} \mathrm{I}^{c}$ & ${ }^{151} \mathrm{Sm}^{a}$ \\
${ }^{244} \mathrm{Cm}^{b}$ & ${ }^{131} \mathrm{Xe}^{d}$ & ${ }^{152} \mathrm{Sm}^{a}$ \\
$\mathrm{O}^{a}$ & ${ }^{135} \mathrm{Xe}^{c}$ & ${ }^{153} \mathrm{Eu}^{a}$ \\
& ${ }^{133} \mathrm{Cs}^{a}$ & ${ }^{154} \mathrm{Eu}^{b}$ \\
& ${ }^{134} \mathrm{Cs}^{d}$ & ${ }^{155} \mathrm{Eu}^{b}$ \\
\hline
\end{tabular}

${ }^{a}$ The 25 nuclides to be used in burnup credit analysis (ref. 4).

${ }^{b}$ Additional burnup credit nuclides from ref. 1 .

${ }^{c}$ Additional reactor physics nuclides from Virginia Power's PDQ calculations (ref. 10).

${ }^{d}$ Additional reactor physics nuclides from Yankee Atomic's

CASMO-3/SIMULATE-3 calculations (ref. 13).

Because fission-product nuclides represent only a small fraction of the total number density of the fuel, fission-product cross sections are relatively insensitive to the varying isotopic content and need only be calculated for one cross-section set. This situation is also true of many fuel activation products and minor actinides; however, cross sections for seven actinides are known to have a more significant burnup dependence. These isotopes, referred to as the "seven burnup-dependent actinides," are ${ }^{234} \mathrm{U},{ }^{235} \mathrm{U},{ }^{236} \mathrm{U},{ }^{238} \mathrm{U},{ }^{239} \mathrm{Pu},{ }^{240} \mathrm{Pu}$, and ${ }^{241} \mathrm{Pu}$. CSASN cross-section set fuel pin models include the appropriate SNIKR-computed concentrations for each of these isotopes; the remaining nuclides are included only in the highest burnup cross-section set. The highest burnup is chosen because it will result in the lowest resonance absorption, and therefore results in a higher and more conservative $\mathrm{k}_{\text {eff }}$; however, the effect is extremely small $(<0.1 \% \Delta \mathrm{k} / \mathrm{k})$.

Once cross sections are computed for each cross-section set, the SCALE utility module $\mathrm{WAX}^{16}$ is used to combine all CSASN cross-section set working libraries into a single working library for subsequent use by KENO V.a. All cross sections from the highest burnup cross-section set (containing all fission and activation isotopes) are copied into the combined library. For each of the 
remaining cross-section set libraries, only the seven burnup-dependent actinides are copied. In addition, for each of the seven burnup-dependent actinides in each cross-section set, the cross-section ID number is modified by prefixing the cross-section set number to the cross-section ID so that the KENO V.a core model can reference the appropriate cross section for each cross-section set. The cross sections with modified ID numbers are then copied into the combined library.

\subsection{PREPARATION OF THE KENO V.a CORE MODEL}

The geometry of the core model is based on the technical specifications of the core geometry; the detailed mechanics of the geometry model are discussed later. Using one-eighth core symmetry, it is possible to build a full-core model using a relatively small number of unique assemblies. For each assembly type, nuclide concentrations are obtained from assembly-specific SNIKR output in KENO V.a mixing table format; thus unique mixture data are available for each assembly type in the model. Within each set of mixing table data, the nuclide ID number of each of the seven burnupdependent actinides is prefixed by the cross-section set number that represents that assembly (this step can be done automatically by SNIKR) so that the effective cross sections computed for the

corresponding cross-section set are utilized. These cross sections are located in the working library prepared as described in the previous subsection. 


\section{PREPARATION OF THE SURRY 1 CYCLE 2 CORE MODEL}

The previous section has given an overview of the technical procedure used in setting up the Surry 1 Cycle 2 reactor critical calculations to provide a broad overview of the entire process before concentrating on the details. This section describes the Surry 1 Cycle 2 core, then details the specifics of each step used to set up a model for this core, based on the geometry, contents, and operating history of the core. Rather than follow the five steps used previously to outline the procedure, this section will describe each distinct aspect of the process, as illustrated by the individual boxes in Fig. 1.

Discussion of the KENO V.a criticality calculation results will be provided in Sect. 4 of this report.

\subsection{CORE DESCRIPTION}

The Surry 1 Cycle 2 core consisted of 157 Westinghouse fuel assemblies, each comprised of a $15 \times 15$ lattice containing 204 fuel rods, 20 control rod guide tubes, and one instrument tube. The core configuration is shown in Fig. 3, where each square represents an assembly position. At-power reactivity control is maintained using four control banks and two shutdown banks of full-length AgIn-Cd control rod clusters, 28 BPR clusters containing a total of 320 fresh and 48 depleted BPRs, and soluble boron. Within each assembly, the lattice positions of guide tubes and/or BPRs are located as illustrated in Fig. 4. The loading of the BPR clusters in Cycle 2 is shown in Fig. 5. Design and operating data were obtained from ref. 17.

The critical conditions modeled in this report are based on HZP conditions at BOC-2 and HFP conditions at EOC-2. The downtime between Cycles 1 and 2 was 99 days (0.271 years).

In the HZP critical at BOC and the HFP critical at EOC the control rod position for each is at or near all rods out (ARO). The ARO condition is advantageous because it reduces the complexity of the calculational model. Partially inserted control rods would require additional axial regions in the KENO V.a model, and the control rods consist of very strong localized neutron absorber materials (silver, indium, cadmium). The advantages of the HZP case are that the temperature is uniform and there is no xenon. In the HFP case, the temperature and xenon distributions are not uniform throughout the core but are a function of the relative power produced by each fuel assembly. Since this information was not available, uniform temperature and xenon distributions were assumed in the HFP KENO V.a model. The critical conditions are given in Table 3.

For BOC-2, six fuel batches were present in the core. Fuel batches $1 \mathrm{~A}$ and 2 were manufactured with 1.9 and $2.6 \mathrm{wt} \%{ }^{235} \mathrm{U}$, respectively. Both batches were initially loaded in Cycle 1. Batch 4 was split into four batches-4A, 4B, 4C, and 4X-with initial enrichments of 1.9, 2.6, 3.3, and $1.9 \mathrm{wt} \%{ }^{235} \mathrm{U}$, respectively. Batches $4 \mathrm{~A}, 4 \mathrm{~B}, 4 \mathrm{C}$, and $4 \mathrm{X}$ were initially loaded in Cycle 2. A fullcore loading map and assembly burnup data for Cycle 2 are included in Appendix A. Table 4 provides a physical description of the significant aspects of the fuel design for all assemblies. 
B Burnable Poison Rod Cluster

(i) Control Rod Cluster

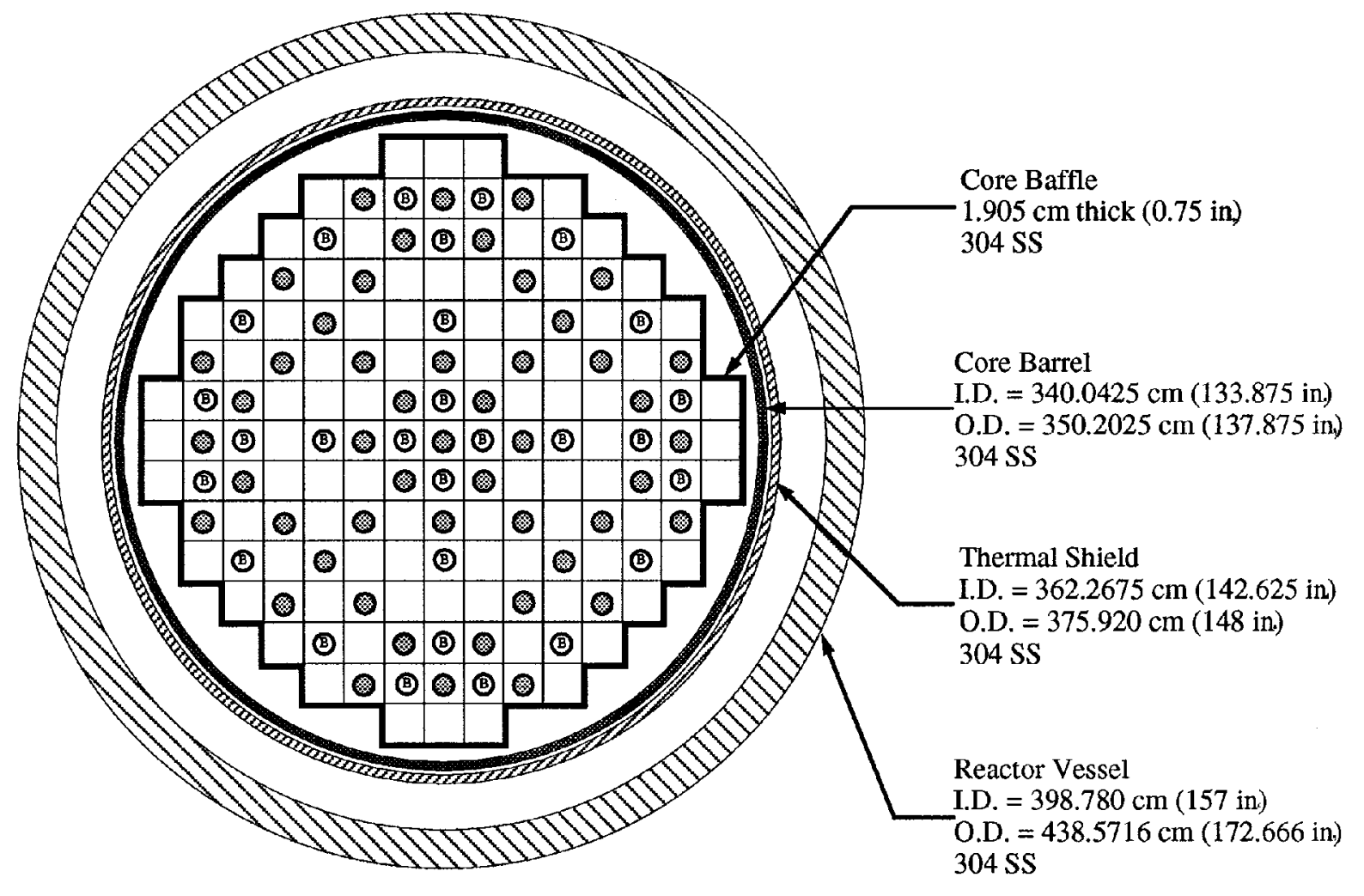

Fig. 3. Surry Unit 1 Cycle 2 core configuration. 
ORNL-DWG 93M-9883

囚 BURNABLE POISON (BP) ROD

$\square$ GUIDE TUBE

d INSTRUMENT TUBE

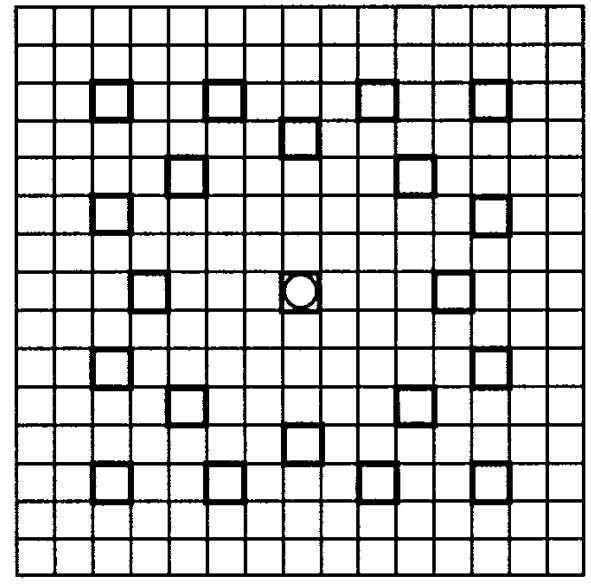

NO BP'S

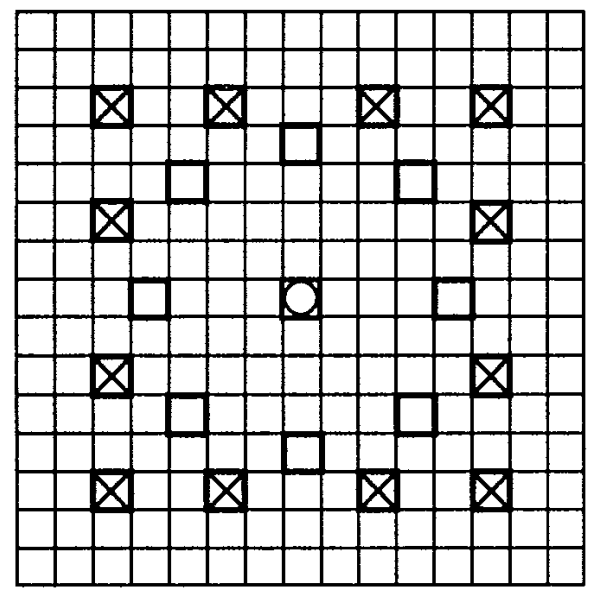

$12 \mathrm{BP}$ 'S

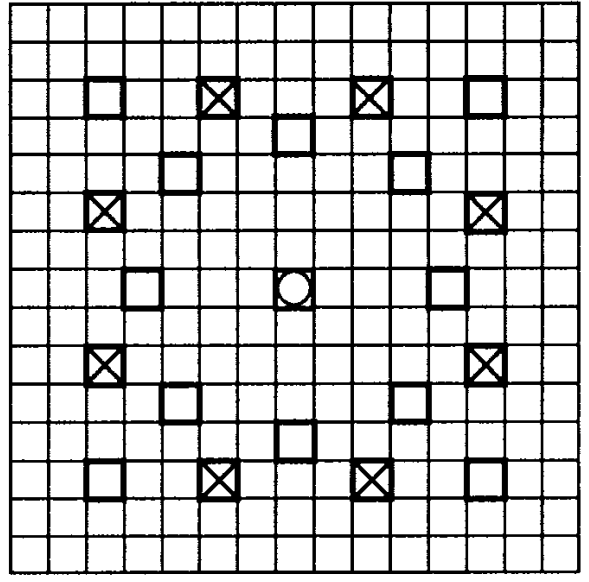

8 BP'S

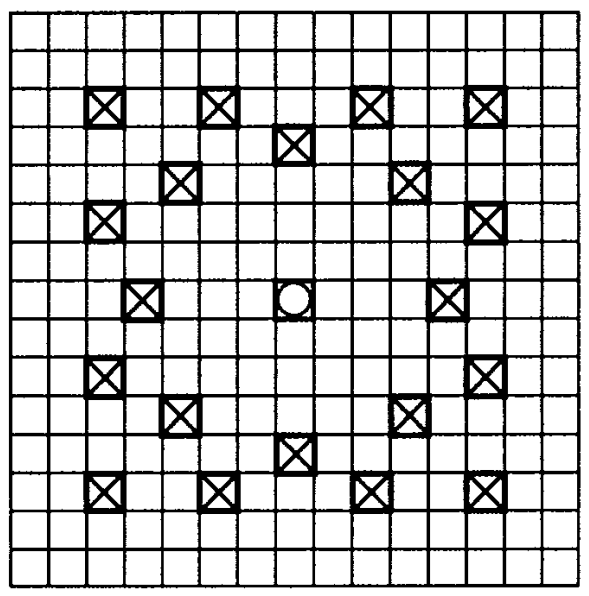

$20 \mathrm{BP}$ 'S

Fig. 4. Fuel assembly lattice arrangements in Surry Unit 1 Cycle 2. 


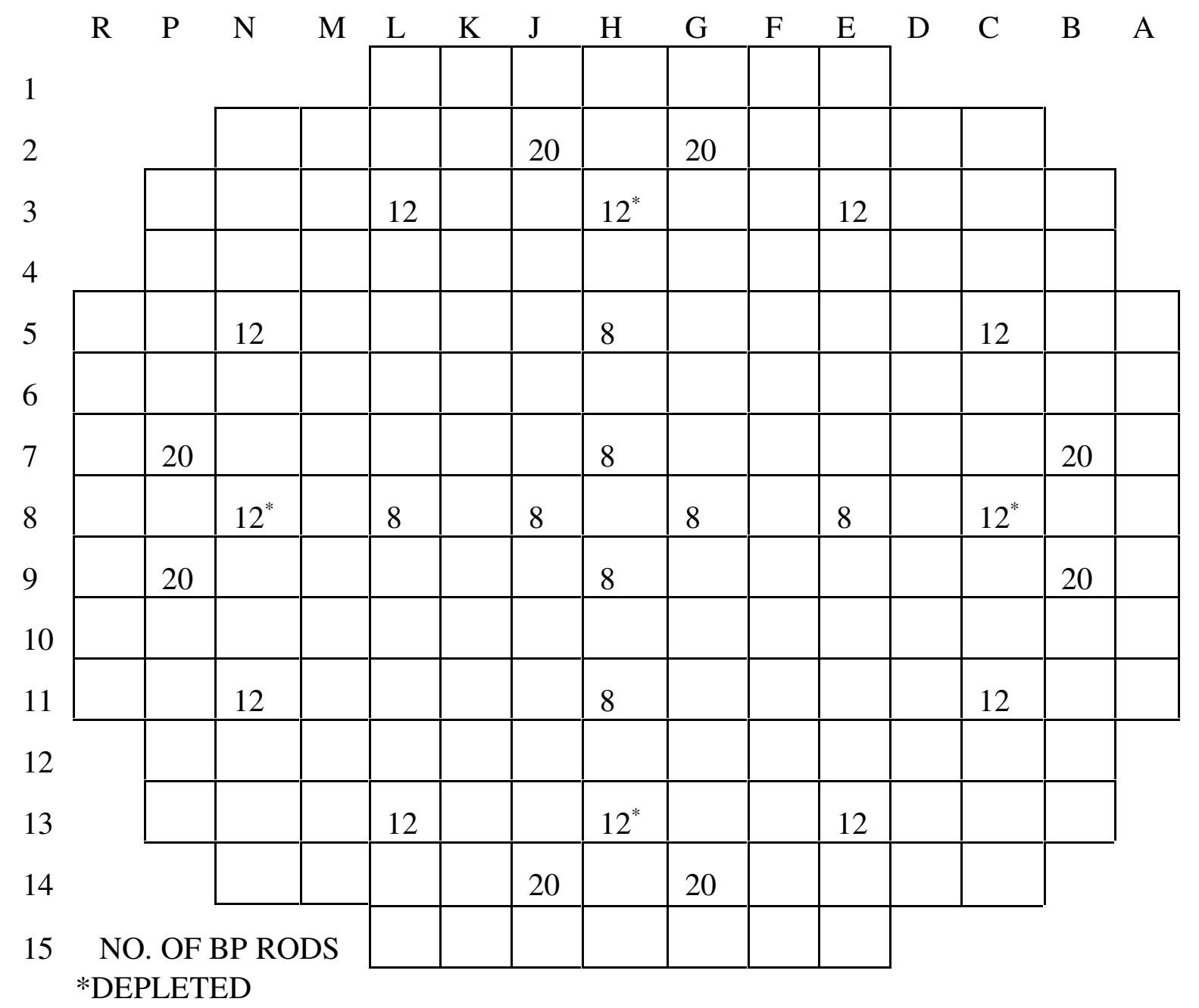

\section{BP RODS \\ 24 FRESH BP CLUSTERS \\ 4 DEPLETED BP CLUSTERS}

Fig. 5. Surry Unit 1 Cycle 2 burnable poison loading configuration. 
Table 3. Surry Unit 1 Cycle 2 measured critical conditions at BOC and EOC

\begin{tabular}{ccccc}
\hline $\begin{array}{c}\text { Time in } \\
\text { cycle }\end{array}$ & $\begin{array}{c}\text { Cycle burnup } \\
(\mathrm{MWd} / \mathrm{MTU})\end{array}$ & Power & $\begin{array}{c}\text { Critical boron } \\
(\mathrm{ppm})\end{array}$ & $\begin{array}{c}\text { Average temp. } \\
(\mathrm{K})\end{array}$ \\
\hline BOC & 0 & HZP & 1030 & 559 \\
& & & & \\
MOC & 6915 & HFP & 123 & 569 \\
\hline
\end{tabular}

Table 4. Surry PWR Unit 1 assembly design description

\begin{tabular}{ll}
\hline Parameter & Data \\
\hline Assembly general data & \\
Number of assemblies & 157 \\
Reactor core heat output, MWt & 2441 \\
Designer & Westinghouse \\
Lattice & $15 \times 15$ \\
Number of fuel rods & 204 \\
Number of guide tubes & 20 \\
Number of instrument tubes & 1 \\
Lattice pitch, cm (in.) & $21.50364(8.466)$ \\
& \\
Fuel rod data & $\mathrm{UO}{ }_{2}$ \\
Type fuel pellet & $1.43002(0.563)$ \\
Rod pitch, cm (in.) & $1.07188(0.422)$ \\
Rod OD, cm (in.) & $0.94844(0.3734)$ \\
Rod ID, cm (in.) & $0.92939(0.3659)$ \\
Pellet diameter, cm (in.) & $365.8(144)$ \\
Active fuel length, cm (in.) & $910(1178)^{a}($ ref. 17$)$ \\
Effective fuel temperature, K $\left({ }^{\circ} \mathrm{F}\right)$ & $595(611)^{a}$ \\
Clad temperature, K ( $\left.{ }^{\circ} \mathrm{F}\right)$ & Zircaloy-4 \\
Clad material & \\
& \\
Guide tube data & $1.3040(0.5134)$ \\
ID, cm (in.) & $1.3802(0.5434)$ \\
OD, cm (in.) & Zircaloy-4 \\
Tube material &
\end{tabular}

${ }^{a}$ Average HFP value. 
To simplify and reduce the volume of input in the KENO V.a model, eighth-core symmetry was assumed in the isotopic input. This assumption reduces the number of unique fuel assemblies to 26 (Fig. 6). The loading pattern for Surry Unit 1 Cycle 2 (Fig. A.1) is eighth-core symmetric.

The assembly burnups were averaged from Table A.1 for BOC and EOC based on the eighthcore symmetry shown in Fig. 6. Assembly burnups listed throughout the remainder of this report are eighth-core average values.

\subsection{SAS2H FUEL GROUPS}

Assemblies of a given fuel batch are generally relocated within the core between cycles, resulting in a more evenly distributed burnup among assemblies because all fuel assemblies in a batch were loaded in the core during the same operating cycles. Because all fuel assemblies in a batch are loaded in the core during the same operating cycles, each assembly in a batch experiences the same operating (uptime/downtime) history. Thus, a starting point for the process of grouping similarcontent assemblies is to begin with fuel batches. As indicated in Fig. 1, assembly group information was used in the preparation of SAS2H input for depletion calculations. For BOC-2, the Surry 1 core was comprised of six fuel batches. Batch $4 \mathrm{X}$, a special test batch of two $17 \times 17$ fuel assemblies, were included with Batch 4A, which was identical in enrichment and symmetrically loaded. Because BPR clusters were loaded in certain assemblies in batches $4 \mathrm{~B}$ and $4 \mathrm{C}$, additional subdivision of these batches was necessary. Each of these two batches were divided into two fuel groups. Batch 4B was divided into 4BB which had burned, or depleted, BPRs and 4BF, which was loaded with fresh BPRs. Batch $4 \mathrm{C}$ was divided into $4 \mathrm{CF}$ and $4 \mathrm{CN}$ for fuel assemblies with fresh BPR clusters and for fuel assemblies with no BPR clusters, respectively. The differences between the 1-D fuel cell model for these two types of fuel groups are discussed in Sects. 3.2.1 and 3.2.2. Each fuel group was modeled as a single unit in a SAS2H depletion calculation over the range of burnups represented by the assemblies in the group. Table 5 provides relevant information about each fuel group.

The initial uranium content of each group was determined from the initial ${ }^{235} \mathrm{U}$ enrichment of the associated fuel batch. The following empirical relationship was used to determine relative isotopic content: $\frac{18}{18}$

$$
\begin{aligned}
& \mathrm{w}_{234}=0.007731\left(\mathrm{w}_{235}\right)^{1.0837}, \\
& \mathrm{w}_{236}=0.0046 \mathrm{w}_{235}, \\
& \mathrm{w}_{238}=100-\mathrm{w}_{234}-\mathrm{w}_{235}-\mathrm{w}_{236},
\end{aligned}
$$

where $w$ is the weight percentage of the given uranium isotope. Using this formulation, the fresh fuel isotopics for all enrichments were computed. The results are given in Table 6.

In addition to the heavy-metal fuel material, light elements are also present in the fuel assembly in the fuel clad and grid. Elements whose masses are typically found to be in excess of $0.5 \mathrm{~g} / \mathrm{kgU}$, plus $\mathrm{Mn}$ and $\mathrm{Co}$, are shown in Table 7, along with their estimated masses. These masses are required by SAS2H. They are not used in the neutronics model, but are applied in determining the $(n, \gamma)$ fraction of energy per fission. 
ORNL-DWG 93M-10021

$\begin{array}{lllllllllllllll}R & P & N & M & L & K & J & H & G & F & E & D & C & B & A\end{array}$

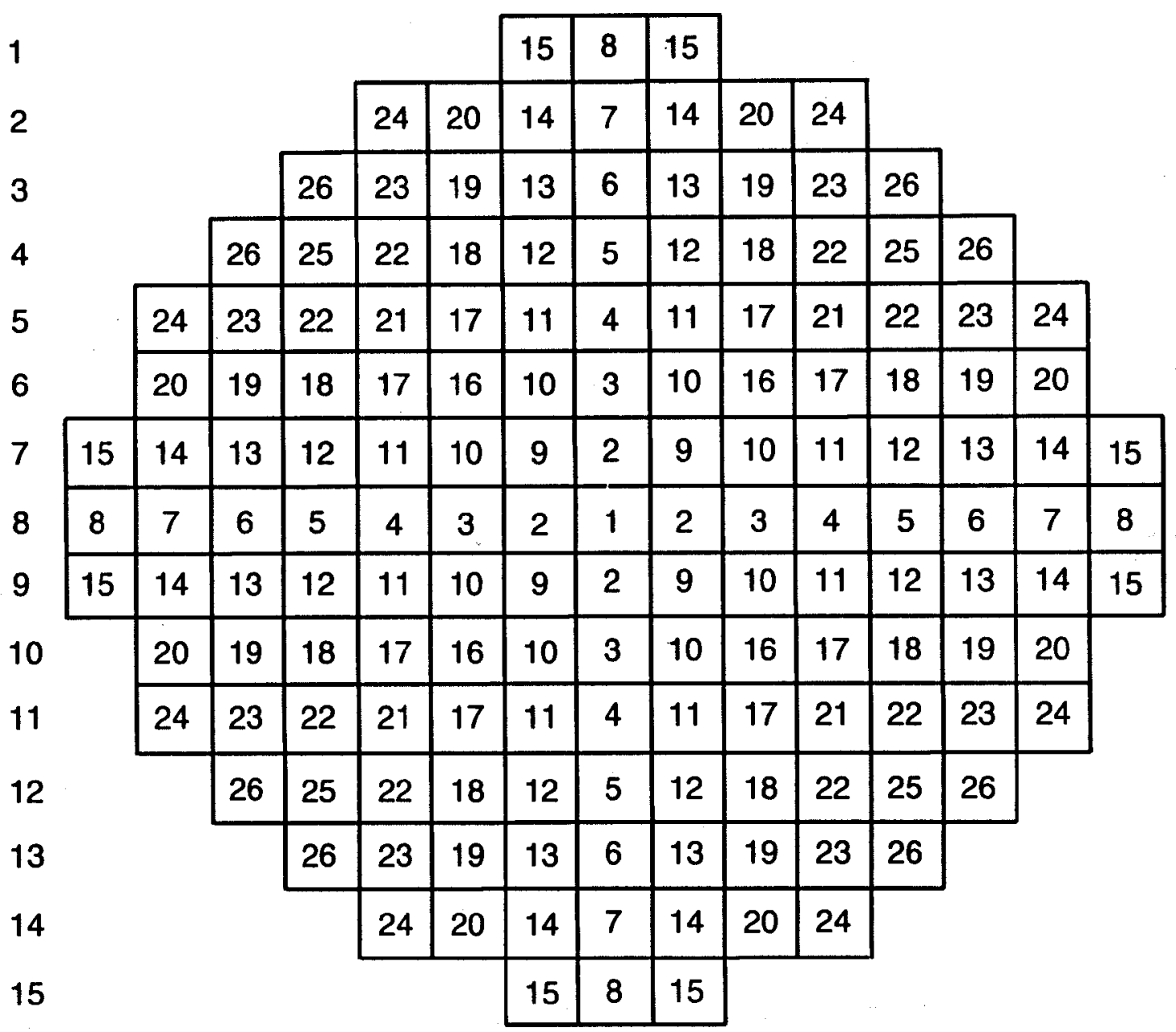

Fig. 6. Surry Unit 1 eighth-core symmetric configuration. 
Table 5. Fuel group data for EOC-2

\begin{tabular}{|c|c|c|c|c|c|c|c|c|}
\hline $\begin{array}{l}\text { SAS2H } \\
\text { fuel } \\
\text { group }\end{array}$ & $\begin{array}{l}\text { Surry-1 } \\
\text { fuel } \\
\text { batch }\end{array}$ & $\begin{array}{c}\text { No. } \\
\text { of } \\
\text { assemblies }\end{array}$ & $\begin{array}{l}\text { Contain } \\
\text { BPRs in } \\
\text { Cycle 2 }\end{array}$ & $\begin{array}{l}\text { Cycles } \\
\text { in-core }\end{array}$ & $\begin{array}{c}\text { Av. B/U } \\
\text { (MWd/MTU) }\end{array}$ & $\begin{array}{c}\text { Min. B/U } \\
\text { (MWd/MTU) }\end{array}$ & $\begin{array}{c}\text { Max. B/U } \\
\text { (MWd/MTU) }\end{array}$ & $\begin{array}{l}\text { Enrichment } \\
\text { (wt \%) }\end{array}$ \\
\hline $1 \mathrm{~A} 2$ & $1 \mathrm{~A} 2$ & 21 & No & 1,2 & 19,792 & 18,501 & 22,094 & 1.868 \\
\hline 2 & 2 & 52 & No & 1,2 & 22,584 & 21,427 & 24,144 & 2.573 \\
\hline $4 \mathrm{~A}$ & $4 A \& 4 X$ & 20 & No & 2 & 7,644 & 6,883 & 8,070 & 1.860 \\
\hline $4 \mathrm{BB}$ & 4B & 4 & Depleted & 2 & 8,428 & 8,428 & 8,428 & 2.610 \\
\hline $4 \mathrm{BF}$ & $4 \mathrm{~B}$ & 8 & Fresh & 2 & 8,506 & 8,372 & 8,639 & 2.610 \\
\hline $4 \mathrm{CN}$ & $4 \mathrm{C}$ & 36 & No & 2 & 6,047 & 5,100 & 7,334 & 3.330 \\
\hline $4 \mathrm{CF}$ & $4 \mathrm{C}$ & 16 & Fresh & 2 & 6,958 & 6,487 & 7,429 & 3.330 \\
\hline
\end{tabular}

Table 6. Initial uranium isotopic content of fresh fuel

\begin{tabular}{ccccc} 
& \multicolumn{4}{c}{ Initial U isotopes, wt \% } \\
\cline { 2 - 5 } $\begin{array}{c}\text { Fuel } \\
\text { batch }\end{array}$ & ${ }^{234} \mathrm{U}$ & ${ }^{235} \mathrm{U}$ & ${ }^{236} \mathrm{U}$ & ${ }^{238} \mathrm{U}$ \\
\hline & & & & \\
1A2 & 0.015 & 1.868 & 0.009 & 98.108 \\
2 & 0.022 & 2.573 & 0.012 & 97.393 \\
4A & 0.015 & 1.860 & 0.009 & 98.116 \\
4B & 0.022 & 2.610 & 0.012 & 97.356 \\
4C & 0.028 & 3.330 & 0.015 & 96.627 \\
\hline
\end{tabular}

Each SAS2H calculation also requires specification of the temperature of each material for use in cross-section Doppler broadening corrections. However, since material and, therefore, thermal properties change with exposure, and because an assembly's peak temperature is a function of its linear heat rate, the average temperature in the fuel (and to a lesser extent the average clad temperature) will change with burnup and location. The only thermal data available were average fuel, clad, and moderator temperatures, as given in Table 4. The operating conditions varied from Cycle 1 to 2. Burnup-averaged values of moderator temperature, pressure, and density for each cycle are listed in Table 8.

\subsubsection{SAS2H Fuel Cell Without BPRs}

The SAS2H fuel cell model input for the four fuel groups without BPR clusters was relatively simple. Requirements included the dimensions of the fuel rod, clad, control-rod guide tube, and lattice pitch and the number of lattice positions in each fuel assembly that are not occupied by fuel rods (i.e., control rod guide tubes or instrumentation tubes). From this basic information included in Table 4, SAS2H constructed a 1-D effective assembly model consisting of a guide tube surrounded by a fuel/moderator region with a volume proportional to the fuel/guide tube volume ratio in the 
Table 7. Light-element masses used in SAS2H calculations

\begin{tabular}{cc} 
Element & $\begin{array}{c}\text { Weight } \\
(\mathrm{g} / \mathrm{kgU})\end{array}$ \\
\hline $\mathrm{O}$ & 135.0 \\
$\mathrm{Cr}$ & 5.9 \\
$\mathrm{Mn}$ & 0.33 \\
$\mathrm{Fe}$ & 12.9 \\
$\mathrm{Co}$ & 0.075 \\
$\mathrm{Ni}$ & 9.9 \\
$\mathrm{Zr}$ & 221.0 \\
$\mathrm{Nb}$ & 0.71 \\
$\mathrm{Sn}$ & 3.6 \\
\hline
\end{tabular}

Table 8. Moderator parameters for Cycles 1 and 2

\begin{tabular}{lcc}
\hline Parameter & Cycle 1 & Cycle 2 \\
\hline Pressure, psia & 2090 & 2250 \\
Temperature, ${ }^{\circ} \mathrm{F}$ & 564.8 & 567 \\
Temperature, $\mathrm{K}$ & 569 & 570 \\
${\text { Density, } \mathrm{g} / \mathrm{cm}^{3}}^{3}$ & 0.7331 & 0.7327 \\
\hline
\end{tabular}

assembly. Cross sections for the fuel region are obtained from a pin cell calculation. More details of this default SAS2H assembly model can be found in ref. 5.

\subsubsection{SAS2H Fuel Cell With BPRs}

For the three fuel groups with BPR clusters (fuel groups 4BB, 4BF, and 4CF), an effective fuel cell was derived to incorporate the BPR cell together with the guide tube cell in SAS2H. In the effective cell, the densities of the isotopes or elements remained unchanged from their actual densities, but rod diameters of the glass and stainless steel in the BPRs were reduced to account for their absence in the guide tube positions. The method of deriving the effective cell was such that the various material total masses were conserved.

The composition of the borosilicate glass as modeled is listed in Table 9. The value for $\mathrm{B}_{2} \mathrm{O}_{3}$ was obtained from Vol. 2 of this report. All other data for typical borosilicate glass were obtained from ref. 19. These data and atomic weights of the elements and isotopic abundance values ${ }^{20}$ were applied in deriving the atomic densities of the borosilicate glass in Table 10. The glass density, $2.23 \mathrm{~g} / \mathrm{cm}^{3}$, was also obtained from ref. 19 . 
The number of BPR assemblies in fuel groups $4 \mathrm{BB}, 4 \mathrm{BF}$, and $4 \mathrm{CF}$ and the number of assemblies having specific combinations of BPRs and guide tubes are shown in Table 11. The total number of BPRs and guide tubes for each group is also given in the table. Applying these totals and the dimensions of the BPRs, guide tubes, and lattice pitch, a set of effective unit cell dimensions were computed. The radius bounding each material was calculated from the outer to inner zone boundary for each average material volume. For example, the water moderator average volume $\bar{V}_{w}$ for fuel group $4 \mathrm{BB}$ is

$$
\bar{V}_{w}=(48)\left(V_{T}-V_{G T}-V_{B P}\right) / 80+(32)\left(V_{T}-V_{G T}\right) / 80,
$$

where

$$
\begin{aligned}
V_{T} & =\text { total cell volume }=(\text { pitch })^{2} \times(\text { length }) \\
V_{G T} & =\text { guide tube volume }(\text { same as outer tube in BPR cell }), \\
V_{B P} & =\text { BP rod total volume }
\end{aligned}
$$

Then the inner radius of the water or the effective radius of the BP rod is

$$
R_{B P}=\sqrt{\left(V_{T}-\bar{V}_{w}-V_{G T}\right) /(\pi L)},
$$

where $L$ is the active fuel length used in computing the volumes. The guide tube dimensions remain the same because they are identical in both types of cells. Each average volume, $V_{\text {ave }}$, within the effective BP rod is calculated from the corresponding actual BP rod dimensions (and totals for group 4BB from Table 11):

$$
V_{\text {ave }}=(48 \pi L)\left(B^{2}-A^{2}\right) / 80,
$$

where

$A=$ the material's inner radius in an actual BP rod,

$B=$ the same material zone's outer radius.

Using the prior calculation of the effective outer radius, $B_{e}$, the effective inner radius, $A_{e}$ is

$$
A_{e}=\sqrt{B_{e}^{2}-V_{a v e} /(\pi L)} .
$$

Equations (1) and (2) are used repeatedly for each material zone for the entire effective cell determination. Applying the above procedure, the effective cell mockup dimensions for the fuel groups with BPRs were computed as listed in Table 12. The densities listed in the table were used only in computing material mass for verification of data. 
Table 9. Borosilicate glass composition in BPR assemblies

\begin{tabular}{lc}
\hline Compound & Weight fraction \\
\hline $\mathrm{SiO}_{2}$ & 0.805 \\
$\mathrm{~B}_{2} \mathrm{O}_{3}$ & 0.125 \\
$\mathrm{Na}_{2} \mathrm{O}$ & 0.038 \\
$\mathrm{~K}_{2} \mathrm{O}$ & 0.004 \\
$\mathrm{Al}_{2} \mathrm{O}_{3}$ & 0.022 \\
\hline
\end{tabular}

Table 10. Borosilicate glass input atom densities ${ }^{a}$

\begin{tabular}{|c|c|c|c|}
\hline Element & Isotope & Weight fraction & $\begin{array}{l}\text { Density } \\
(\text { atoms/barn`cm) }\end{array}$ \\
\hline $\mathrm{O}$ & & 0.5358 & 0.04497 \\
\hline $\mathrm{Na}$ & & 0.0282 & 0.00165 \\
\hline $\mathrm{Al}$ & & 0.0116 & 0.00058 \\
\hline $\mathrm{Si}$ & & 0.3763 & 0.01799 \\
\hline $\mathrm{K}$ & & 0.0033 & 0.00011 \\
\hline B & & 0.03882 & \\
\hline & ${ }^{10} \mathrm{~B}$ & & $9.595 \mathrm{E}-4^{b}$ \\
\hline & ${ }^{10} \mathrm{~B}$ (depleted) & & $2.380 \mathrm{E}-5$ \\
\hline & ${ }^{11} \mathrm{~B}$ & & $3.863 \mathrm{E}-3$ \\
\hline Total & & 0.99402 & \\
\hline
\end{tabular}


Table 11. Number of BPRs and guide tubes in fuel groups with BPRs

\begin{tabular}{|c|c|c|c|c|c|c|c|}
\hline \multirow[b]{2}{*}{$\begin{array}{l}\text { Fuel } \\
\text { group }\end{array}$} & \multirow[b]{2}{*}{$\begin{array}{l}\text { Fuel } \\
\text { batch }\end{array}$} & \multirow[b]{2}{*}{$\begin{array}{c}\text { Number } \\
\text { of } \\
\text { assemblies }\end{array}$} & \multicolumn{2}{|c|}{ Number/assembly } & \multicolumn{3}{|c|}{ Total number } \\
\hline & & & BP rods & $\begin{array}{l}\text { Guide } \\
\text { tubes }\end{array}$ & BP rods & $\begin{array}{l}\text { Guide } \\
\text { tubes }\end{array}$ & $\begin{array}{l}\text { Nonfuel }^{a} \\
\text { locations }\end{array}$ \\
\hline $4 \mathrm{BB}$ & $4 B$ & 4 & 12 & 8 & 48 & 32 & 80 \\
\hline $4 \mathrm{BF}$ & $4 B$ & 8 & 8 & 12 & 64 & 96 & 160 \\
\hline $4 \mathrm{CF}$ & $4 \mathrm{C}$ & 8 & 12 & 8 & 96 & 64 & 160 \\
\hline $4 \mathrm{CF}$ & $4 \mathrm{C}$ & 8 & 20 & 0 & 160 & 0 & 160 \\
\hline $\begin{array}{c}4 \mathrm{CF} \\
\text { (Total) }\end{array}$ & & 16 & & & 256 & 64 & 320 \\
\hline
\end{tabular}

${ }^{a}$ Excluding instrument tube.

Table 12. Effective fuel cells with BPRs

\begin{tabular}{|c|c|c|c|c|c|c|}
\hline \multirow[b]{2}{*}{ Zone } & \multirow[b]{2}{*}{ Material } & \multirow[b]{2}{*}{$\begin{array}{l}\text { Density } \\
\left(\mathrm{g} / \mathrm{cm}^{3}\right)\end{array}$} & \multirow[b]{2}{*}{$\begin{array}{l}\text { SAS2H } \\
\text { Mixture } \\
\text { number }\end{array}$} & \multicolumn{3}{|c|}{ Radius in cell, $\mathrm{cm}$} \\
\hline & & & & $\begin{array}{l}\text { Fuel group } \\
\text { 4BB }\end{array}$ & $\begin{array}{l}\text { Fuel group } \\
4 \mathrm{BF}\end{array}$ & $\begin{array}{c}\text { Fuel group } \\
4 \mathrm{CF}\end{array}$ \\
\hline 1 & Air & $1.22 \mathrm{E}-3^{a}$ & 7 & 0.21457 & 0.17519 & 0.24776 \\
\hline 2 & SS-304 & 7.92 & 5 & 0.22705 & 0.18538 & 0.26217 \\
\hline 3 & Air & $1.22 \mathrm{E}-3$ & 7 & 0.23329 & 0.19048 & 0.26938 \\
\hline 4 & Glass & 2.23 & 6 & 0.38017 & 0.31041 & 0.43898 \\
\hline 5 & Air & $1.22 \mathrm{E}-3$ & 7 & 0.38449 & 0.31394 & 0.44397 \\
\hline 6 & SS-304 & 7.92 & 5 & 0.42001 & 0.34294 & 0.48499 \\
\hline 7 & Mod & 0.7149 & 3 & 0.65202 & 0.65202 & 0.65202 \\
\hline 8 & $\mathrm{Zr}-4$ & 6.44 & 2 & 0.69012 & 0.69012 & 0.69012 \\
\hline 9 & Mod & 0.7149 & 3 & 0.80680 & 0.80680 & 0.80680 \\
\hline 10 & Fuel & 10.3682 & 500 & 2.64088 & 2.64088 & 2.64088 \\
\hline
\end{tabular}

${ }^{a}$ Read as $1.22 \times 10^{-3}$. 
The total material masses of the actual BP rods plus that of the guide tubes were compared with the effective cell total masses. The data were used to verify the cell dimensions. In all cases identical weights were computed for the same materials, verifying that the effective cells conserve mass.

\subsection{SIMILAR-BURNUP SUBGROUPING FOR CROSS-SECTION SETS}

Although the assemblies of a given fuel group are identical in terms of initial composition, time in core, and operating history, there may be a relatively broad range of burnups within a fuel group. Even though effective cross sections are felt to be insensitive to minor variations in burnups, it is necessary to set a maximum range of burnups for which an average burnup is an acceptable approximation in determining cross sections. As demonstrated in Sect. 3.8, a range of no more than $2 \mathrm{GWd} / \mathrm{MTU}$ has been found to be acceptable; this value was used in subdividing fuel groups into similar-burnup cross-section sets. As shown in Fig. 1, cross-section set information is provided to SNIKR for subsequent use in setting up CSASN calculations. CSASN is used to compute effective cross sections for each cross-section set. Since cross sections had to be calculated at BOC-2 and EOC-2, fuel groups had to be subdivided into cross-section sets at both burnups.

To determine cross-section sets for each fuel group, the fuel assembly burnups in each group were sorted and divided into subgroups where the minimum to maximum burnup range was no larger than $2 \mathrm{GWd}$ /MTU. Eighth-core averaged assembly burnups are given in Table 13, along with fuel batch, SAS2H fuel group, and cross-section set information. The cross-section set groupings are shown in Table 14. Tables 15 and 16 show the cross-section sets at BOC and EOC, with the actual burnup ranges for assemblies within each cross-section set, along with the mean average burnup of all assemblies in each cross-section set. Note that except for group 4CN, no subgrouping was necessary for the fuel groups that were fresh fuel when loaded at BOC-2.

\subsection{SAS2H DEPLETION CALCULATIONS}

SAS2H depletion calculations were required for all fuel groups since all fuel assemblies loaded at the EOC-2 case consisted of spent fuel. In the standard composition section of the SAS2H input for each fuel group, the initial uranium isotopic contents for the $\mathrm{UO}_{2}$ fuel were as given in Table 6. Although not initially present in the fuel, the additional 44 nuclides from Table 1 were included at an atom density of $1 \times 10^{-20}\left({ }^{135} \mathrm{Xe}\right.$ was specified with an initial density on the order of its equilibrium concentration, since it quickly reaches this equilibrium concentration shortly after startup), indicating to SAS2H that cross sections for these isotopes should be updated at the end of each burn cycle, as discussed previously in Sect. 2.2. The remainder of the fuel pin cell was described

as Zircaloy clad in water with temperature and geometry data, as specified in Table 4 . The active fuel length was divided by the total weight of heavy metal in the assembly. This modification gives results in units of burnup per MTU rather than burnup per assembly. Since SAS2H uses a 1-D assembly cell model, the fuel length is arbitrary and may be used as a conversion factor. 
Table 13. Fuel assembly data for eighth-core geometry

\begin{tabular}{|c|c|c|c|c|c|c|}
\hline \multirow{2}{*}{$\begin{array}{c}\text { Eighth-core } \\
\text { location }\end{array}$} & \multirow{2}{*}{$\begin{array}{l}\text { Surry } \\
\text { fuel batch }\end{array}$} & \multirow{2}{*}{$\begin{array}{l}\text { SAS2H } \\
\text { fuel group }\end{array}$} & \multicolumn{2}{|c|}{ Cross-section set } & \multicolumn{2}{|c|}{$\begin{array}{c}\text { Average burnup } \\
\text { (MWd/MTU) }\end{array}$} \\
\hline & & & $\mathrm{BOC}$ & MOC & $\mathrm{BOC}$ & $\mathrm{MOC}$ \\
\hline 1 & $1 \mathrm{~A} 2$ & $1 \mathrm{~A} 2$ & 2 & 2 & 15,316 & 22,094 \\
\hline 2 & $4 \mathrm{~B}$ & $4 \mathrm{BF}$ & 7 & 7 & 0 & 8,639 \\
\hline 3 & $1 \mathrm{~A} 2$ & $1 \mathrm{~A} 2$ & 1 & 1 & 12,535 & 19,597 \\
\hline 4 & $4 \mathrm{~B}$ & $4 \mathrm{BG}$ & 7 & 7 & 0 & 8,373 \\
\hline 5 & 2 & 2 & 4 & 4 & 15,224 & 22,670 \\
\hline 6 & $4 \mathrm{~B}$ & $4 \mathrm{BB}$ & 6 & 6 & 0 & 8,428 \\
\hline 7 & $1 \mathrm{~A} 2$ & $1 \mathrm{~A} 2$ & 2 & 1 & 14,764 & 20,407 \\
\hline 8 & $4 \mathrm{C}$ & $4 \mathrm{CN}$ & 8 & 9 & 0 & 6,398 \\
\hline 9 & 2 & 2 & 4 & 4 & 16,280 & 24,144 \\
\hline 10 & $4 \mathrm{~A}$ & $4 \mathrm{~A}$ & 5 & 5 & 0 & 8,070 \\
\hline 11 & 2 & 2 & 3 & 3 & 14,128 & 21,879 \\
\hline 12 & 2 & 2 & 4 & 4 & 15,831 & 22,793 \\
\hline 13 & 2 & 2 & 3 & 3 & 14,371 & 21,427 \\
\hline 14 & $4 C$ & $4 \mathrm{CF}$ & 9 & 10 & 0 & 6,487 \\
\hline 15 & $4 \mathrm{C}$ & $4 \mathrm{CN}$ & 8 & 8 & 0 & 5,100 \\
\hline 16 & $1 \mathrm{~A} 2$ & $1 \mathrm{~A} 2$ & 1 & 1 & 11,553 & 18,501 \\
\hline 17 & $4 \mathrm{~A}$ & $4 \mathrm{~A}$ & 5 & 5 & 0 & 7,599 \\
\hline 18 & 2 & 2 & 4 & 4 & 15,787 & 22,535 \\
\hline 19 & $1 \mathrm{~A} 2$ & $1 \mathrm{~A} 2$ & 2 & 1 & 14,187 & 19,939 \\
\hline 20 & $4 \mathrm{C}$ & $4 \mathrm{CN}$ & 8 & 9 & 0 & 7,334 \\
\hline 21 & 2 & 2 & 4 & 4 & 16,587 & 23,534 \\
\hline 22 & 2 & 2 & 4 & 4 & 16,298 & 22,989 \\
\hline 23 & $4 \mathrm{C}$ & $4 \mathrm{CF}$ & 9 & 10 & 0 & 7,429 \\
\hline 24 & $4 \mathrm{C}$ & $4 \mathrm{CN}$ & 8 & 8 & 0 & 5,508 \\
\hline 25 & $4 \mathrm{~A}$ & $4 \mathrm{~A}$ & 5 & 5 & 0 & 6,883 \\
\hline 26 & $4 \mathrm{C}$ & $4 \mathrm{CN}$ & 8 & 8 & 0 & 6,072 \\
\hline
\end{tabular}


Table 14. Cross-section sets for one-eighth core assemblies

\begin{tabular}{|c|c|c|c|c|c|}
\hline \multicolumn{3}{|c|}{ BOC } & \multicolumn{3}{|c|}{ EOC } \\
\hline $\begin{array}{c}\text { Cross-section } \\
\text { set No. }\end{array}$ & $\begin{array}{c}\text { Assembly } \\
\text { No. }\end{array}$ & $\begin{array}{c}\text { Burnup } \\
(\mathrm{MWd} / \mathrm{MTU})\end{array}$ & $\begin{array}{c}\text { Cross-section } \\
\text { set No. }\end{array}$ & $\begin{array}{c}\text { Assembly } \\
\text { No. }\end{array}$ & $\begin{array}{c}\text { Burnup } \\
\text { (MWd/MTU) }\end{array}$ \\
\hline \multirow[t]{4}{*}{1} & 3 & 12,535 & \multirow[t]{3}{*}{1} & 3 & 19,597 \\
\hline & 16 & 11,553 & & 7 & 20,407 \\
\hline & Average & 12,044 & & 16 & 18,501 \\
\hline & & & \multirow{5}{*}{2} & 19 & 19,939 \\
\hline \multirow[t]{4}{*}{2} & 1 & 15,316 & & \multirow[t]{2}{*}{ Average } & \multirow[t]{2}{*}{19,677} \\
\hline & 7 & 14,764 & & & \\
\hline & 19 & 14,187 & & 1 & 22,094 \\
\hline & Average & 14,451 & & Average & 22,094 \\
\hline \multirow[t]{3}{*}{3} & 11 & 14,128 & \multirow[t]{3}{*}{3} & 11 & 21,879 \\
\hline & 13 & 14,371 & & 13 & 21,427 \\
\hline & Average & 14,249 & & Average & 21,653 \\
\hline \multirow[t]{7}{*}{4} & 5 & 15,224 & \multirow[t]{7}{*}{4} & 5 & 22,670 \\
\hline & 9 & 16,280 & & 9 & 24,144 \\
\hline & 12 & 15,831 & & 12 & 22,793 \\
\hline & 18 & 15,787 & & 18 & 22,535 \\
\hline & 21 & 16,587 & & 21 & 23,534 \\
\hline & 22 & 16,298 & & 22 & 22,989 \\
\hline & Average & 15,991 & & Average & 22,998 \\
\hline \multirow[t]{4}{*}{5} & 10 & 0 & \multirow[t]{4}{*}{5} & 10 & 8,070 \\
\hline & 17 & 0 & & 17 & 7,599 \\
\hline & 25 & 0 & & 25 & 6,883 \\
\hline & Average & 0 & & Average & 7,644 \\
\hline \multirow[t]{2}{*}{6} & 6 & 0 & \multirow[t]{2}{*}{6} & 6 & 8,428 \\
\hline & Average & 0 & & Average & 8,428 \\
\hline \multirow[t]{3}{*}{7} & 2 & 0 & \multirow[t]{3}{*}{7} & 2 & 8,639 \\
\hline & 4 & 0 & & 4 & 8,373 \\
\hline & Average & 0 & & Average & 8,506 \\
\hline \multirow[t]{7}{*}{8} & 14 & 0 & \multirow[t]{4}{*}{8} & 14 & 6,487 \\
\hline & 15 & 0 & & 23 & 7,429 \\
\hline & 23 & 0 & & Average & 6,958 \\
\hline & 24 & 0 & & & \\
\hline & 26 & 0 & \multirow[t]{3}{*}{9} & 15 & 5,100 \\
\hline & Average & 0 & & 24 & 5,508 \\
\hline & & & & 26 & 6,072 \\
\hline \multirow[t]{5}{*}{9} & 8 & 0 & \multirow{5}{*}{10} & Average & 5,560 \\
\hline & 20 & 0 & & & \\
\hline & Average & 0 & & 8 & 6,398 \\
\hline & & & & 20 & 7,334 \\
\hline & & & & Average & 7,022 \\
\hline
\end{tabular}


Table 15. Cross-section sets for Surry Unit 1 Cycle 2 BOC

\begin{tabular}{clclccc}
$\begin{array}{c}\text { Cross-section } \\
\text { set No. }\end{array}$ & $\begin{array}{c}\text { SAS2H } \\
\text { fuel } \\
\text { group }\end{array}$ & Enrichment & $\begin{array}{c}\text { Burnable } \\
\text { poison rods } \\
\text { (BPR) }\end{array}$ & $\begin{array}{c}\text { Average } \\
\text { burnup }\end{array}$ & $\begin{array}{c}\text { Burnup } \\
\text { range }\end{array}$ & $\begin{array}{c}\text { No. of } \\
\text { assemblies }\end{array}$ \\
\hline 1 & $1 \mathrm{~A} 2$ & 1.87 & None & 12,044 & $11,553-12,535$ & 2 \\
2 & $1 \mathrm{~A} 2$ & 1.87 & None & 14,451 & $14,187-15,316$ & 3 \\
3 & 2 & 2.57 & None & 14,249 & $14,128-14,371$ & 2 \\
4 & 2 & 2.57 & None & 15,991 & $15,224-16,587$ & 6 \\
5 & 4A & 1.86 & None & 0 & 0 & 3 \\
6 & 4BB & 2.61 & Depleted & 0 & 0 & 1 \\
7 & 4BF & 2.61 & Fresh & 0 & 0 & 2 \\
8 & 4CN & 3.33 & None & 0 & 0 & 5 \\
9 & 4CF & 3.33 & Fresh & 0 & 0 & 2 \\
\hline
\end{tabular}

Table 16. Cross-section sets for Surry Unit 1 Cycle 2 EOC

\begin{tabular}{clclccc}
\hline $\begin{array}{c}\text { Cross-section } \\
\text { set No. }\end{array}$ & $\begin{array}{c}\text { SAS2H } \\
\text { fuel } \\
\text { group }\end{array}$ & Enrichment & $\begin{array}{c}\text { Burnable } \\
\text { poison rods } \\
\text { (BPR) }\end{array}$ & $\begin{array}{c}\text { Average } \\
\text { burnup }\end{array}$ & $\begin{array}{c}\text { Burnup } \\
\text { range }\end{array}$ & $\begin{array}{c}\text { No. of } \\
\text { assemblies }\end{array}$ \\
\hline 1 & $1 \mathrm{~A} 2$ & 1.87 & None & 19,677 & $18,501-20,407$ & 4 \\
2 & $1 \mathrm{~A} 2$ & 1.87 & None & 22,094 & 22,094 & 1 \\
3 & 2 & 2.57 & None & 21,653 & $21,427-21,879$ & 2 \\
4 & 2 & 2.57 & None & 22,998 & $22,535-24,144$ & 6 \\
5 & $4 \mathrm{~A}$ & 1.86 & None & 7,644 & $6,883-8,070$ & 3 \\
6 & $4 \mathrm{BB}$ & 2.61 & Depleted & 8,428 & 8,428 & 1 \\
7 & 4BF & 2.61 & Fresh & 8,506 & $8,372-8,639$ & 2 \\
8 & $4 \mathrm{CN}$ & 3.33 & None & 5,560 & $5,100-6,072$ & 3 \\
9 & $4 \mathrm{CN}$ & 3.33 & None & 7,022 & $6,398-7,334$ & 2 \\
10 & 4CF & 3.33 & Fresh & 6,958 & $6,487-7,429$ & 2 \\
\hline
\end{tabular}

Table 17 gives the power history data used for each SAS2H fuel group. Note that a constant burnup per interval was used for each fuel group; this constant spacing is required by SNIKR when interpolating from SAS2H/ORIGEN output. Shorter burnup intervals were used for the fresh fuel loaded in Cycle 2 (batches 4A, 4B, 4C, and 4X) to have a sufficient number of data points for SNIKR to interpolate. The number of intervals for each group was chosen so that the maximum assembly burnup was exceeded by at least $20 \%$. The average specific power for each fuel group was calculated by dividing the group average burnup by the total uptime for each cycle that the fuel was in the core. Calendar days were used for Cycle 1, whereas the effective full-power days (EFPD) were used for Cycle 2. The average power in Cycle 1, during which the reactor operated at reduced power, was appropriate. However, it should be more accurate to apply EFPD during Cycle 2 because the reactor was operating at or near full power most of the cycle (including the end of cycle), and concentrations of some of the short-lived isotopes produced by neutron capture tend to be proportional to the final power. Since the EOC-2 critical is at HFP, equilibrium conditions, these short-lived isotopes are 


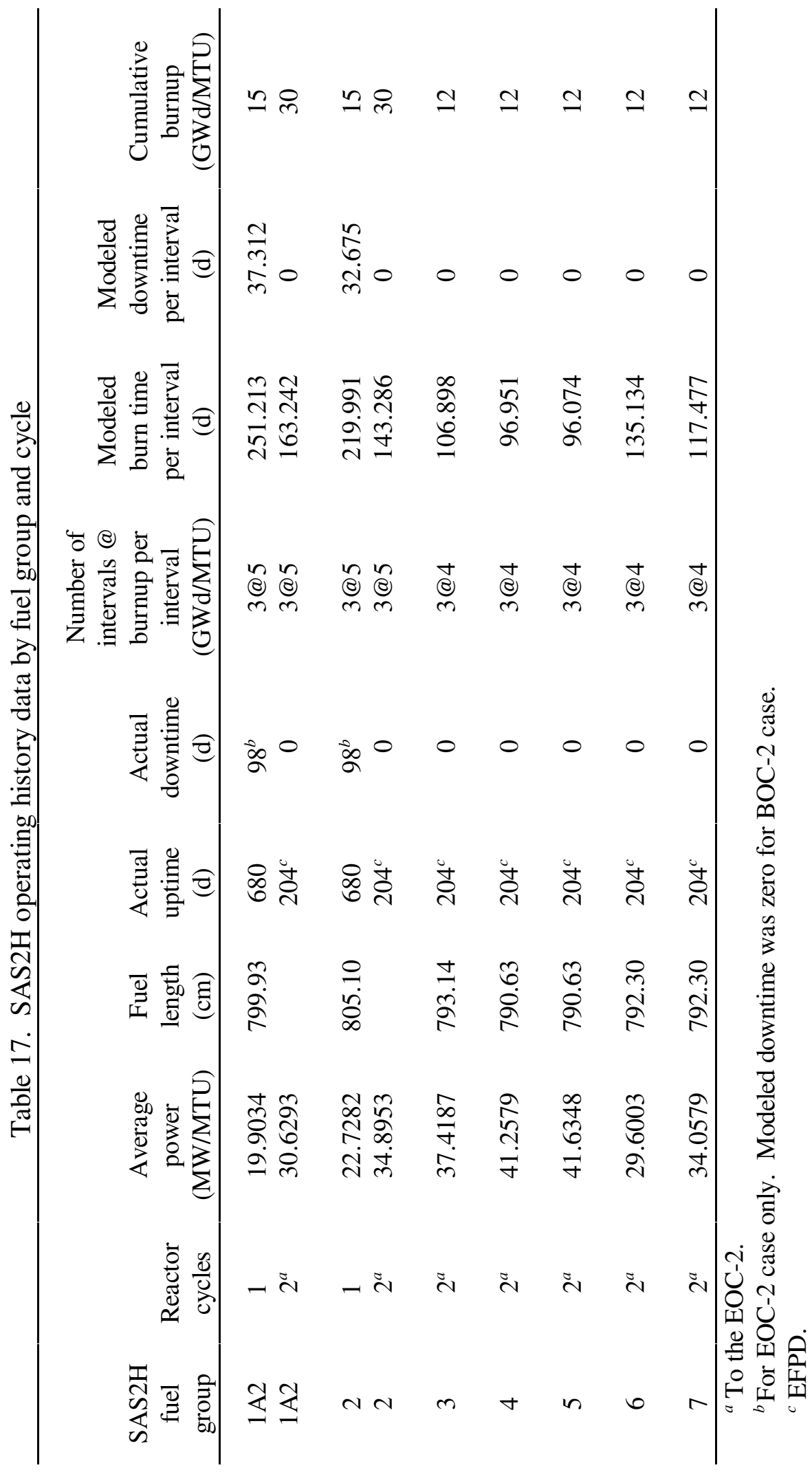


important. As explained previously in Sect. 2.2, the ratio of uptime to downtime for Cycle 1 was used to determine the length of downtime following each burnup interval for the fuel in the first cycle. No downtime was applied for any of the fuel groups during Cycle 2, since the EOC-2 case occurs at HFP equilibrium conditions with no prior downtime.

A copy of the SAS2H input for fuel group 4BF is included in Appendix B. With the exception of the uranium isotopics, the burnup steps, and the BPR data, inputs for the other fuel group calculations were identical.

\subsection{BURNUP-DEPENDENT INTERPOLATION OF ISOTOPICS}

The atom density output files from each of the previous SAS2H calculations contain isotopic concentrations for the associated fuel group at each burnup step. Using the appropriate group output, SNIKR1 was used to interpolate between burnup intervals to estimate the isotopic concentration corresponding to the burnup of each assembly and cross-section set in the Surry 1 models at BOC-2 and EOC-2. This step was the only one necessary for the EOC-2 case, since it occurred at HFP, equilibrium conditions. For the BOC-2 case, SNIKR1 then used these isotopics (which represented nuclide concentrations at the end of the depletion prior to the critical condition at BOC-2) and prepared an ORIGEN-S decay calculation to obtain the concentration of the isotopes after the appropriate downtime of 0.271 years prior to the BOC-2 startup. After ORIGEN-S was executed, SNIKR3 read the ORIGEN-S output and prepared isotopic concentration tables in both SCALE standard composition input format and KENO mixing table format, for the selected set of isotopes listed previously in Table 2.

The SNIKR sequence consists of three codes, as previously described in Sect. 2.3, and requires two files. The first file is a SNIKR input file describing the calculation to be performed for a specific assembly or cross-section set; the second is the SAS2H output file containing the atom density data for the appropriate fuel group. SNIKR calculations are automated in a manner similar to SCALE calculational sequences such that the multistep calling of the individual code packages is transparent to the user. Appendix C lists a user input guide for SNIKR Version 1.0, which was used in these analyses, and FORTRAN listings of SNIKR1 and SNIKR3. The SAS2H and SNIKR calculations were performed on the ORNL IBM/MVS 3090 mainframe computer using SCALE-4.1.

Slightly different approaches are taken between preparation of assembly isotopics and crosssection set isotopics as the results are used in different applications. The following subsections describe each of the two methods.

\subsubsection{Assembly Isotopics}

In the KENO V.a model of Surry Unit 1 Cycle 2 eighth-core averaged assembly isotopics calculations are used to provide the nuclide concentrations for each assembly position. The assembly isotopics are based on the average burnup for the assembly, and all fuel rods within the assembly are assumed to possess the same isotopic composition. Hence, material numbers for each fuel rod in a given assembly are identical and correspond to a specific KENO V.a mixture number. This mixture is defined based on results of SNIKR calculations for the burnup of the corresponding assembly. In the Surry KENO V.a model, mixture numbers 101 through 126 correspond to SNIKR calculations 
for assemblies 1 through 26, respectively. Eighth-core averaged assembly burnups are given in Table 13, along with fuel group and cross-section set information.

Sample SNIKR input files for BOC and EOC are listed in Tables D.1 and E.1, respectively. As discussed earlier in Sect. 2.4, cross-section-set-dependent cross sections are required only for the seven burnup-dependent actinides. SNIKR places the cross-section ID modifier in front of the default cross-section ID for each of these isotopes (e.g., ${ }^{238} \mathrm{U}$, with ID No. 92238, would be described as 292238 for all assemblies located in cross-section set 2). Burnable poison isotopics were similarly generated for each of the five eighth-core fuel assembly locations where BPRs were present in Cycle 2. A sample input file is listed in Table E.2.

The SNIKR output file consists of three sections: a summary of the input and coarsely formatted ORIGEN-S results, isotopic concentrations in SCALE standard composition input format, and isotopic concentrations in KENO V.a mixing table input format. For each assembly calculation, only the latter was of interest; this section was copied and placed directly into KENO V.a input to describe the isotopic composition for the burnup of a specific assembly. A sample SNIKR output is listed in Appendix C.

\subsubsection{Cross-Section Set Isotopics}

Burnup-dependent cross sections were required for the seven burnup-dependent actinides. As was previously mentioned, cross-section set calculations were performed with CSASN to obtain the cross sections for these actinides for each cross-section set based on the average burnup groupings shown in Table 13; these groupings were selected based on the burnup range criterion of $2 \mathrm{GWd} / \mathrm{MTU}$ discussed earlier. SNIKR calculations were required for all cross-section sets, except the fresh fuel sets 5 through 9 at BOC. The seven burnup-dependent actinides were needed for each set of burned fuel at BOC and EOC. In addition, cross-section set 4 also included the other actinides and fission products in the fuel mixture, along with the moderator and structural materials. The microscopic cross-section calculations for cross-section sets 6, 7, 9 (BOC), and 10 (EOC) included the BP nuclides. A sample SNIKR input file is shown in Table D.2.

The SNIKR output file is the same format as was produced for the assembly calculations; however, the region of output data which was of interest was different. The isotopic concentrations in SCALE standard composition input format were copied to a CSASN input file.

\subsection{GENERATION OF CROSS SECTIONS USING CSASN}

Problem-dependent cross-section libraries were produced using the CSASN sequence of SCALE; the details of this process were described in Sect. 2.4. For each cross-section set, a CSASN input deck containing cross-section set average isotopics was created. Because the physical geometries of all fuel pins were identical, input specifications differed only in the isotopic compositions specified for each set. All cases were set up to use the SCALE ENDF/B-IV and ENDF/B-V based 27-group 27BURNUPLIB cross-section library. All calculations were LATTICECELL-type, with fuel in a Zircaloy clad; dimensions are specified in Table 4. A boratedwater moderator was specified, with the appropriate boron concentration as specified in Table 3. For $\mathrm{HZP}$, all components were specified with a temperature of $559 \mathrm{~K}\left(547^{\circ} \mathrm{F}\right)$, corresponding to $\mathrm{HZP}$ 
conditions. For HFP, appropriate temperatures from Tables 4 and 8 were specified for each component. The example input for HZP and HFP, respectively, are shown in Tables D.3 and E.3. Isotopic concentrations were obtained from the earlier SNIKR cross-section set calculations. If only the seven burnup-dependent actinides were required, except for set 4 , all other actinides and fission products were deleted from the fuel mixture specifications for these cases. Cross-section sets 5 through 9, comprised only of fresh fuel at BOC, HZP, were specified using the fresh isotopic compositions given in Table 6 for that case. The microscopic cross-section calculations for crosssection set 4 also included the other actinides and fission products in the fuel mixture, along with mixtures for the moderator and structural materials. Cross-section set 4 was selected for these calculations because its spent fuel isotopics represented the highest average burnup (16,587 MWd/MTU at BOC and 22,998 MWd/MTU at EOC). The example input for cross-section set 4 is included as Tables D.4 and E.4. The microscopic cross-section calculations for cross-section sets 6, 7, and 9 (BOC) and 10 (EOC) included the BPR nuclides. CSASN calculations were then performed, with the resulting microscopic working format cross-section library saved for each crosssection set.

\subsection{COMBINING CROSS-SECTION SET LIBRARIES USING WAX}

The WAX program ${ }^{16}$ was used to combine the individual working format libraries (one per cross-section set) into a single library for BOC-2 and another for EOC-2 to be used in the KENO V.a core calculations. For cross-section set 4 , selected to include the fission products and additional actinides, WAX copied all cross sections into the combined library. For the cross-section sets selected for the BPR cross sections, WAX copied those cross sections in addition to the seven burnup-dependent actinides. For the remaining cross-section sets, WAX copied only the cross sections for the seven burnup-dependent actinides. For each of these actinides, the cross-section ID was modified by adding the cross-section set number as a prefix, to be consistent with the numbering scheme used in the SNIKR-produced KENO V.a mixing-table-format isotopics for each assembly. Sample WAX input listings are provided in Tables D.5 and E.5. All CSASN and WAX calculations were performed with SCALE-4.1 on the ORNL IBM mainframe.

\subsection{VALIDATION OF CROSS-SECTION SET ASSUMPTIONS}

The methodology of cross-section generation employing cross-section sets resulted in each fuel assembly in the KENO V.a full-core model being modeled with microscopic cross sections generated with isotopics based on the average burnup for a cross-section set (i.e., a subgroup of fuel). In order to validate this methodology, the highest burnup assemblies in cross-section sets 2 (BOC) and 4 (EOC) were analyzed by executing an XSDRNPM $^{21}$ eigenvalue calculation in stand-alone mode and via the ${\operatorname{CSAS} 1 X^{6}}^{6}$ sequence (BONAMI, NITAWL-II, XSDRNPM). The stand-alone calculations utilized the working format libraries created by WAX that were based on cross-section set averaged isotopics. The CSAS1X calculations generated and used problem-specific microscopic cross sections based on the calculated assembly isotopics. Cross-section sets 2 and 4 were selected for the validation because they represented the highest burnup sets with the largest spans in burnup for their 
respective enrichments. Individual assembly locations 1 and 9 were selected because they represented the maximum burnup, and, hence, the maximum difference in isotopics from the average, for their respective cross-section sets. These cases should give the poorest agreement since the change in microscopic cross sections should be greatest at higher burnups and for the largest difference in assembly-to-average burnup. The results of these cases are compared in Table 18, which shows a maximum difference of $0.035 \% \Delta \mathrm{k} / \mathrm{k}$ due to the use of the cross sections at subgroup-averaged conditions. Input files are included in Tables D.6 and D.7 and E.6 and E.7.

\subsection{PREPARATION OF KENO V.a CORE MODEL}

The KENO V.a model used to determine $\mathrm{k}_{\text {eff }}$ for the Surry 1 BOC- 2 and EOC- 2 cores consists of four parts. The first section of input contains code parameter specifications. The only significant aspect of this section is the use of 1003 generations of 1000 neutrons per generation; hence, the calculation was based on one million histories (three generations were skipped by KENO V.a). Parameter specifications are followed by mixture specifications, geometry specifications, and plotting specifications. The plotting specifications are unimportant in the criticality calculation and were simply used in debugging and verifying geometry input. The following subsections describe the details of the material and geometry specifications for this model.

\subsubsection{KENO V.a Mixture Specifications}

In describing the composition of a fuel assembly, it has been assumed that all fuel rods in the assembly are identical and may be represented by the assembly-averaged burnup. No attempt was made to account for burnup asymmetries within an assembly, as this information was not readily available and should have little effect on the computed solution. Thus, only a single fuel rod description is necessary to describe all fuel rods in a given assembly. In addition, in this model, axial power distributions are ignored, and assemblies are represented by a model that assumes a constant (average) power distribution along the length of the assembly. Thus the composition of fuel in an assembly is uniform and is represented by a single material specification. Based on the results of an axial end effects study,,$_{22}^{22}$ this assumption has a minor effect $(<0.1 \% \Delta \mathrm{k} / \mathrm{k})$ that is probably conservative for the average burnup in these models. Because it is possible to take advantage of the one-eighth core symmetry of the core, only 26 assemblies are required to represent all 157 assembly positions in the core. Hence, only 26 material mixtures are necessary for the full-core model. These come from the 26 assembly calculations performed earlier using SNIKR for mixtures 101 through 126. The portions of the SNIKR output copied into the KENO V.a input represent complete mixture specifications for each of the 26 materials.

Material specifications were also required for all remaining materials (i.e., clad, borated water, and BPR materials). Concentrations for each isotope were obtained from the output of the CSASN cross-section calculations. Mixture numbers 11 through 15 were used for the burnable poison materials. A unique mixture number was assigned the BPR in each eighth-core fuel assembly that contained BPRs. This designation was necessary for the EOC-2 case where the BPRs were partially depleted and varied with assembly burnup. Table 19 lists all materials included in the core model by

mixture number. 
Table 18. $\mathrm{k}_{\infty}$ comparison for validation of cross-section methodology

\begin{tabular}{|c|c|c|c|c|c|}
\hline \multirow[b]{2}{*}{ Burnup } & \multirow[b]{2}{*}{ Power } & \multirow{2}{*}{$\begin{array}{l}\text { Eighth- } \\
\text { core } \\
\text { assembly } \\
\text { location }\end{array}$} & \multicolumn{2}{|c|}{$\mathrm{k}_{\infty}$} & \multirow[b]{2}{*}{$\%$ Difference } \\
\hline & & & $\begin{array}{l}\text { XSDRNPM } \\
\text { stand-alone }\end{array}$ & $\begin{array}{l}\text { CSAS1X } \\
\text { sequence }\end{array}$ & \\
\hline $\mathrm{BOC}$ & $\mathrm{HZP}$ & 1 & 0.913483 & 0.913159 & 0.035 \\
\hline $\mathrm{EOC}$ & HFP & 9 & 0.953601 & 0.953760 & -0.017 \\
\hline
\end{tabular}

\subsubsection{KENO V.a Geometry Specifications}

A fuel rod was defined for each of the 26 one-eighth core fuel assemblies based on the dimensions given in Table 4. Identical dimensions were used for all rod definitions. Fuel rods were assigned to Unit numbers 101 to 126, respectively; the fuel region of each rod was linked to its corresponding material number (e.g., fuel rod 101 used material 101 for the fuel region). All rods were specified with a void gap and Zircaloy clad, centered in a water cuboid. Fuel rods and enclosing cuboids were modeled as having a length equal to that of the active fuel length of the rod (i.e., fuel assembly top and bottom structures were neglected). A 50/50 mixture of borated $\mathrm{H}_{2} \mathrm{O}$ and stainless steel was used as a top and bottom reflector (25-cm-thick) to account for structural materials above and below the active fuel region.

Unit 161, representing a control rod guide tube, was created using the dimensions in Table 4, with water inside the tube and centered within a water cuboid. Burnable poison rods were created as Units 162 through 166. Each BPR was put inside a control rod guide tube.

A $17 \times 17$ array was then defined for each of the 26 fuel assemblies, which were assigned Unit numbers 1 through 26 corresponding to their eighth-core location. The 204 fuel rod locations in each assembly were filled with the fuel rod containing the assembly average isotopics. The remaining array locations were appropriately filled with guide tubes or BPRs according to the full-core BPR loading configuration in Fig. 5 and the fuel assembly lattice arrangements in Fig. 4. Each array was surrounded by a thin layer of moderator to obtain an assembly lattice spacing of $21.50364 \mathrm{~cm}$ (8.466 in.).

The core baffle surrounding the outermost assemblies was created as a composite of several smaller segments, comprised of four different cuboid shapes. Units 41 to 46 were used to define these shapes. Figure 7 illustrates the use of these six unit types in modeling the core baffle. The figure also shows assembly position numbers for the full core, based on one-eighth core symmetry and the numbering scheme shown in Fig. 6. Using these position numbers, arrays of assemblies and core baffle segments were used to define larger units, to minimize the number of KENO V.a "holes" placed in the global unit. Figure 8 illustrates the grouping of assemblies used. Global Unit 70 contained the core barrel, thermal shield, and reactor vessel. All other units were placed within Unit 70 using KENO V.a "holes." Note that core baffle components drawn in black in the figure represent 
Table 19. Mixtures in KENO V.a model

\begin{tabular}{cl}
$\begin{array}{c}\text { Mixture } \\
\text { No. }\end{array}$ & \multicolumn{1}{c}{ Description } \\
\hline 1 & Clad \\
2 & Stainless steel (BP clad, baffle) \\
3 & Borated moderator \\
4 & $50 \%$ borated moderator, 50\% stainless steel (top and bottom reflector) \\
5 & Stainless steel (core barrel) \\
6 & Borated moderator (outside core barrel) \\
7 & Stainless steel (thermal shield) \\
8 & Borated moderator (outside thermal shield) \\
9 & Stainless steel (reactor vessel) \\
$11-15$ & Burnable poison, assemblies 2, 4, 6, 14, 23 \\
$101-126$ & Fuel, assemblies 1-26 \\
\hline
\end{tabular}




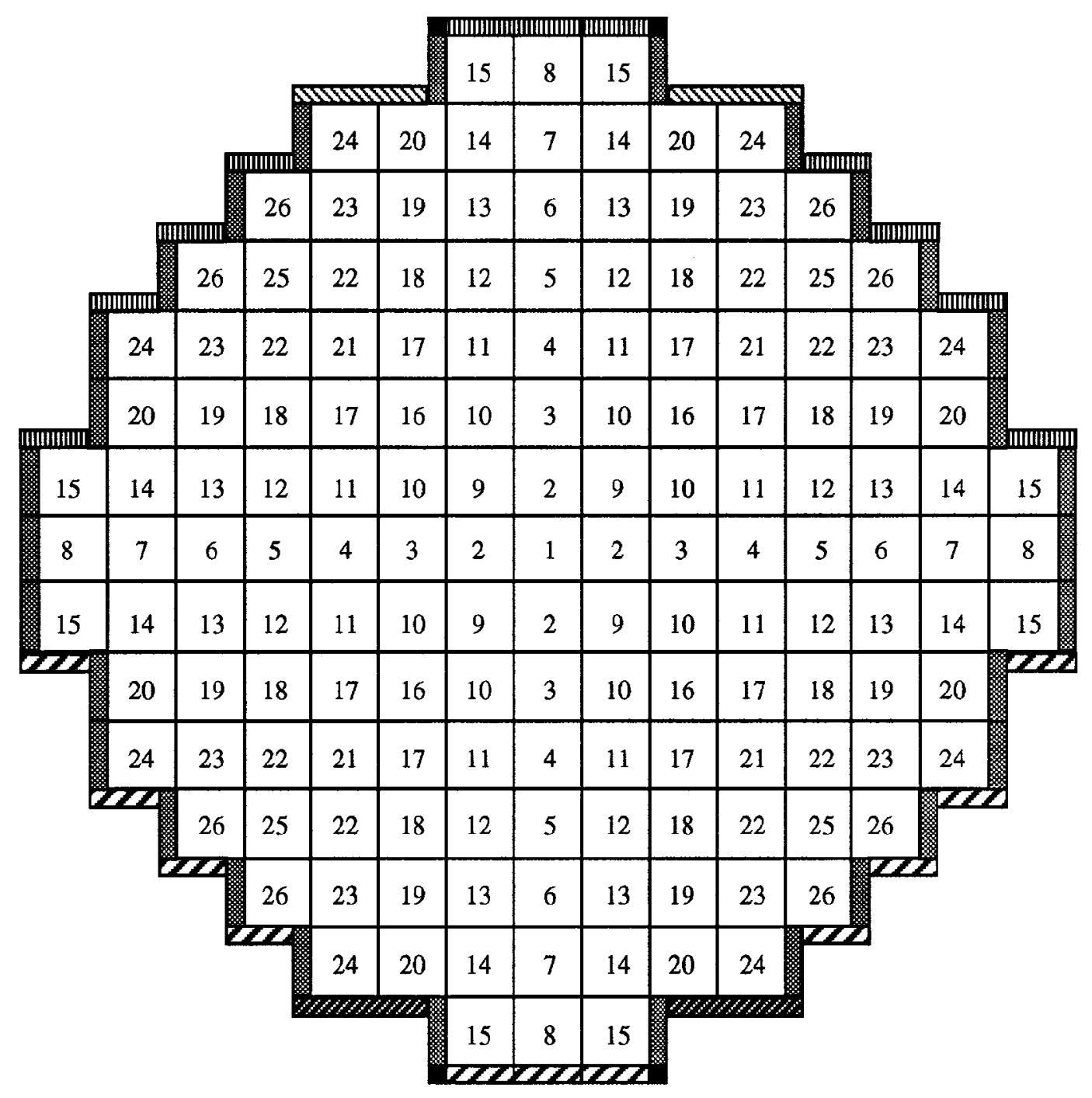

Corner Baffle Segment (Unit 41)

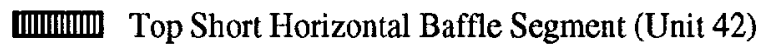

Vertical Baffle Segment (Unit 43)

Top Long Horizontal Baffle Segment (Unit 44)

WOA Bottom Short Horizontal Baffle Segment (Unit 45)

W2Z2 Bottom Long Horizontal Baffle Segment (Unit 46)

Fig. 7. Full-core assembly positions and core baffle configuration. 


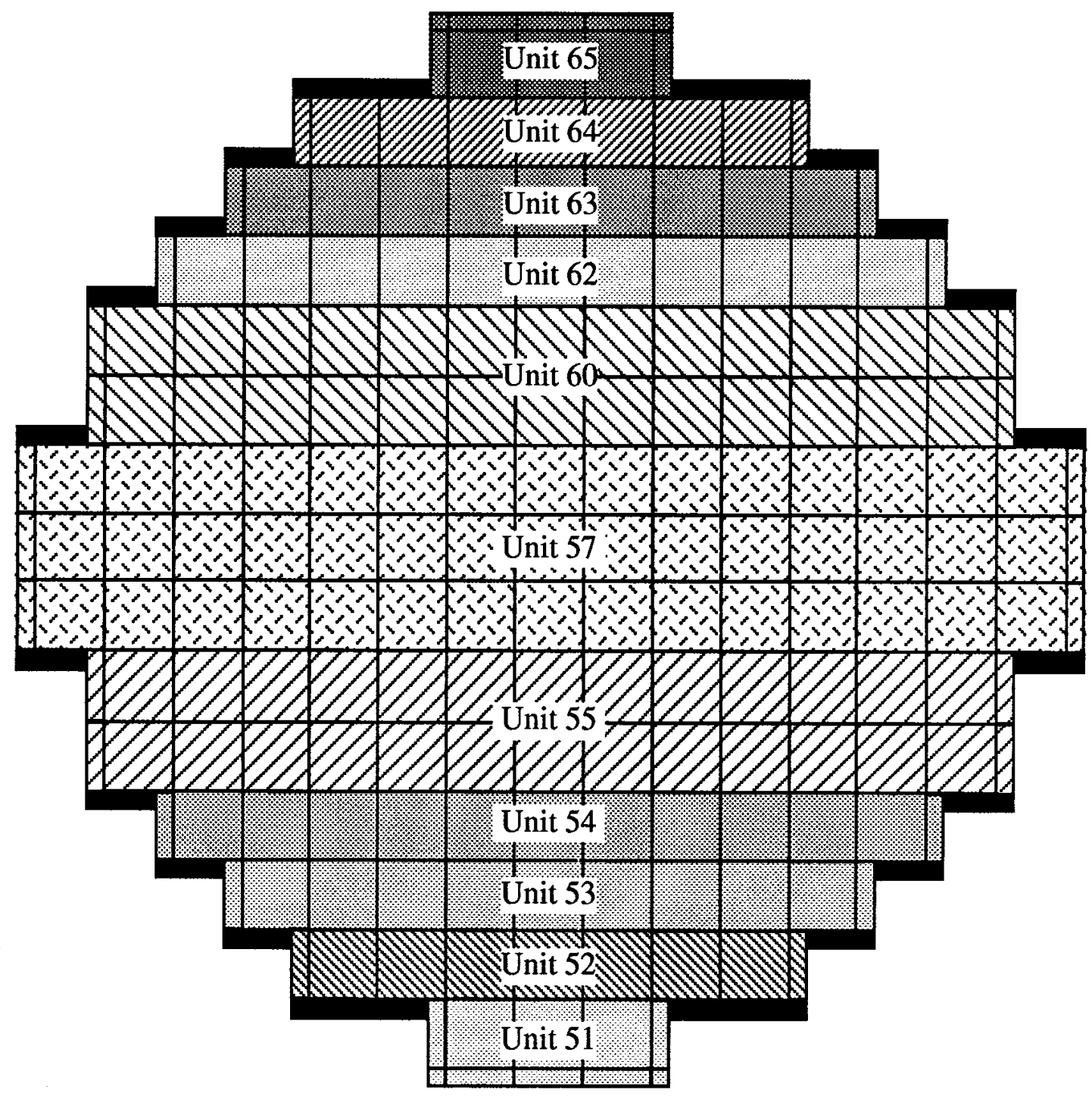

Fig. 8. KENO V.a unit definitions based on component arrays. 
individual components not included in these arrays and were entered as individual holes in the global array. Unit number assignments used in the model are given in Table 20.

This discussion completes the geometric description of the core. As a reference, a listing of the entire KENO V.a input for the BOC-2 HZP case and the EOC-2 HFP case are included in Tables D.8 and E.8, respectively. All KENO V.a calculations were performed with SCALE-4.2 on an IBM RS-6000 workstation after the cross-section libraries created with WAX had been transferred from the ORNL IBM mainframe. 
Table 20. Unit numbers used in Surry KENO V.a core model

\begin{tabular}{ll}
\hline Unit & \\
No. & \\
\hline $1-26$ & Fuel assemblies for positions 1 to 26 , respectively \\
41 & $1.905 \times 1.905 \mathrm{~cm}$ (corner) segment of core baffle \\
42 & $21.50364 \times 1.905 \mathrm{~cm}$ (horizontal) segment of core baffle \\
43 & $1.905 \times 21.50364 \mathrm{~cm}$ (vertical) segment of core baffle \\
44 & $43.00728 \times 1.905 \mathrm{~cm}$ (horizontal) segment of core baffle \\
45 & $21.50364 \times 1.905 \mathrm{~cm}$ (horizontal) segment of core baffle \\
46 & $43.00728 \times 1.905 \mathrm{~cm}$ (horizontal) segment of core baffle \\
51 & "Bottom" of baffle + row 1 of assemblies + vertical baffle ends \\
52 & Row 2 of assemblies + vertical baffle ends \\
53 & Row 3 of assemblies + vertical baffle ends \\
54 & Row 4 of assemblies + vertical baffle ends \\
55 & Rows 5 and 6 of assemblies + vertical baffle ends \\
57 & Rows $7-9$ of assemblies + vertical baffle ends \\
60 & Rows 10 and 11 of assemblies + vertical baffle ends \\
62 & Row 12 of assemblies + vertical baffle ends \\
63 & Row 13 of assemblies + vertical baffle ends \\
64 & Row 14 of assemblies + vertical baffle ends \\
65 & Row 15 of assemblies + vertical baffle ends + "top" of baffle \\
$70($ GLOBAL $)$ & Reactor vessel + thermal shield + core barrel + vertical baffle ends \\
$101-126$ & Fuel rods for assemblies $1-6$, respectively \\
161 & Water-filled control rod guide tube \\
$162-166$ & BPRs in control rod guide tubes \\
&
\end{tabular}




\section{RESULTS AND CONCLUSIONS}

The KENO V.a criticality calculations for the Surry 1 Cycle 2 BOC and EOC models described in this report yielded values for $\mathrm{k}_{\text {eff }}$ from 1.0014 to 1.0113, as shown in Table 21. These results cover different burnup, power, xenon, and temperature conditions. The range of conditions for these reactor criticals are listed in Table 22. The results are based on 1000 generations of 1000 neutrons per generation, for a total of $1 \times 10^{6}$ histories. Included in Table 21 is the average fission group reported by SCALE, which represents the average neutron energy at which fission occurs. Numerical experiments with a different starting random number and different starting source shape and location indicate that these solutions are well converged and adequate source sampling achieved (see ref. 7 for a discussion of what constitutes convergence).

The EOC case contains all spent fuel, but the fuel has experienced no cooling time. Therefore, short-lived fission products are present in this reactor critical that are not present in any of the other criticals. Since the nuclides modeled in the reactor critical calculations are primarily longlived actinides and fission products, with the exception of ${ }^{135} \mathrm{I}$ and ${ }^{135} \mathrm{Xe}$, there may be some important short-lived nuclides omitted in the KENO V.a model that account for the higher calculated $\mathrm{k}_{\text {eff }}$ value for this critical. Another important factor is that the critical boron concentration for the EOC case is not well documented or characterized. The uncertainty of this measured value may also contribute to the higher calculated value.

The results in Table 21 were based on $\mathrm{P}_{3}$ scattering; however, a test case using (default) $\mathrm{P}_{1}$ scattering showed no significant change (within $0.1 \%$ ) in $\mathrm{k}_{\text {eff. }}$. This result is as would be expected, since angular fluxes throughout a reactor core would be expected to be relatively uniform except near the outer boundary of the core.

Relative fission density distributions (normalized to the core-average value) computed by KENO V.a are shown in Figs. 9 and 10 for a one-eighth core average. These distributions may be interpreted as relative power densities and show the approximate shape expected for an operating PWR core, indicating no major anomalies in the core assembly model. The use of uniform temperature and xenon distributions for the HFP case causes the KENO V.a distributions to be less uniform over the inner-core regions due to the lack of xenon and temperature feedback mechanisms. Note that even though $\mathrm{k}_{\text {eff }}$, a total system parameter, is considered to be well converged, individual assembly fission distributions are based on substantially fewer histories, especially in outer-core regions, and therefore are subject to significantly higher uncertainties.

These $\mathrm{k}_{\text {eff }}$ results are approximately $2 \% \Delta \mathrm{k} / \mathrm{k}$ greater than those reported for the Surry and North Anna reactor critical benchmark calculation $\$$ performed with the original SCALE scoping calculations. Differences in the earlier analyses that have been identified and their probable order of importance are use of a lumped fission product to account for all nuclides not explicitly modeled, fewer fuel batches and cross-section sets, fewer neutrons per generation and fewer total neutron histories, and use of an earlier version of SAS2H.

The consistency in results for the revised methodology and its straightforward procedure for calculating isotopics provide a high level of confidence in these results. The complexity in the isotopic calculational procedure of the initial methodology, the use of lumped fission products, and 
Table 21. KENO V.a calculated results for Surry Unit 1 Cycle 2

\begin{tabular}{lccccc}
\hline Burnup & Power & $\begin{array}{c}\text { Boron } \\
(\mathrm{ppm})\end{array}$ & $\mathrm{k}_{\text {eff }}$ & $\begin{array}{c}\text { Average energy } \\
\text { group where } \\
\text { fission occurs }\end{array}$ & $\begin{array}{c}\text { Neutron } \\
\text { histories }\end{array}$ \\
\hline BOC & HZP & 1030 & $1.0014 \pm 0.0005$ & $21.0183 \pm 0.0036$ & $1,000,000$ \\
& & 123 & $1.0113 \pm 0.0005$ & $20.9735 \pm 0.0035$ & $1,000,000$ \\
\hline \multicolumn{2}{l}{ EOC } & HFP & 123 The energy range for group 20 is 0.8 to $0.4 \mathrm{eV}$.
\end{tabular}

Table 22. Range of conditions for Surry reactor criticals

\begin{tabular}{lccccc}
\hline Case & $\begin{array}{c}\text { Core avg. } \\
\text { burnup } \\
(\mathrm{MWd} / \mathrm{MTU})\end{array}$ & $\begin{array}{c}\text { Power } \\
(\mathrm{MW})\end{array}$ & $\begin{array}{c}\text { Mod. } \\
\text { temp. } \\
(\mathrm{K})\end{array}$ & $\begin{array}{c}\text { Fuel } \\
\text { temp. } \\
(\mathrm{K})\end{array}$ & $\begin{array}{c}\text { Xenon } \\
\text { worth } \\
(\% \Delta \mathrm{k} / \mathrm{k})\end{array}$ \\
\hline BOC,HZP & 6,929 & 0 & 559 & 559 & 0 \\
EOC,HFP & 13,845 & 2441 & 569 & 910 & 2.82 \\
\hline
\end{tabular}


ORNL-DWG 94M-4801

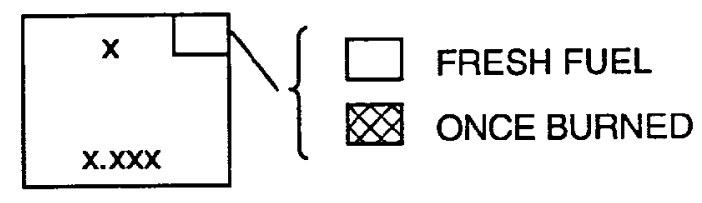

1/8 CORE ASS'Y LOCATION

RELATIVE FISSION DENSITY

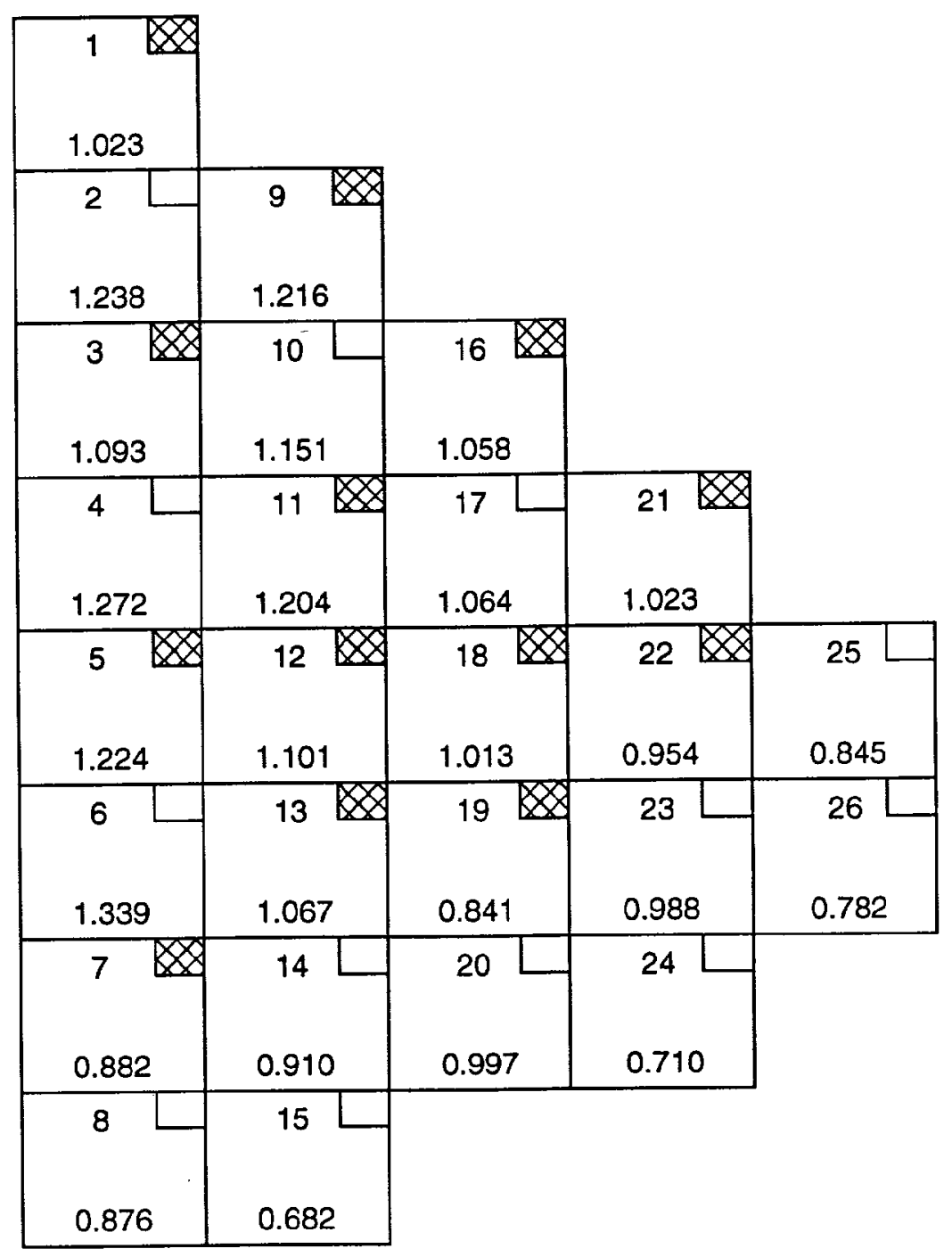

Fig. 9. BOC, HZP eighth-core relative fission density distribution. 
ORNL-DWG 94M-4802

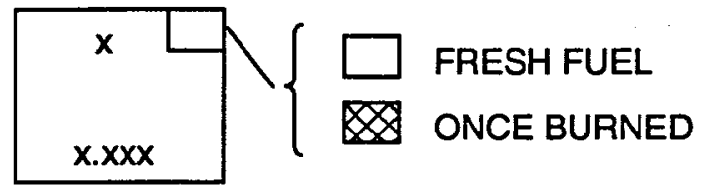

1/8 CORE ASS'Y LOCATION

RELATIVE FISSION DENSITY

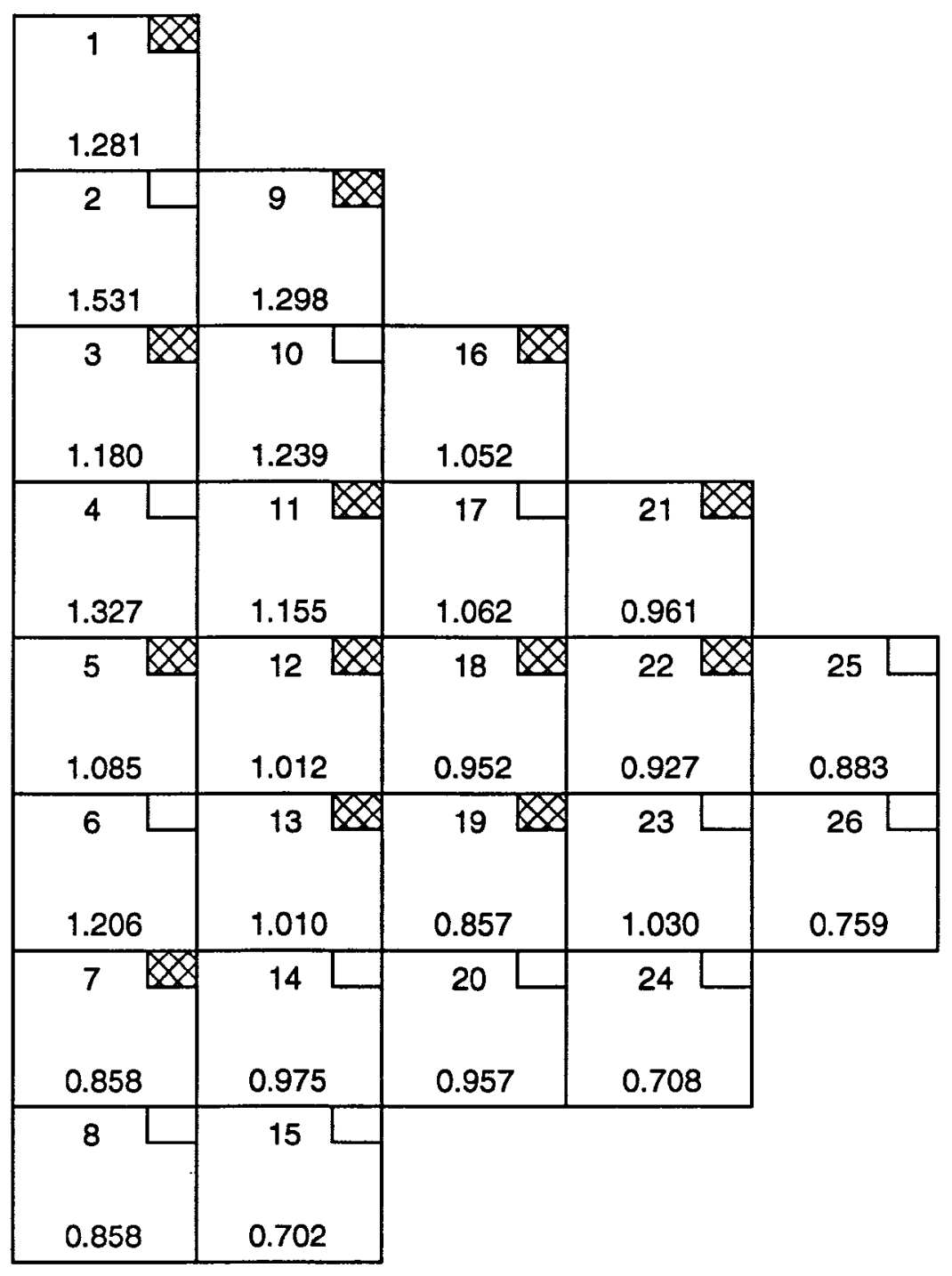

Fig. 10. EOC, HFP eighth-core relative fission density distribution. 
the inability to reproduce results caused by the loss of data from the earlier work reduces our confidence in the original calculations.

The results of these calculations demonstrate that even with a relatively simple core model and eighth-core and assembly-averaged burnups, it is possible to closely predict, in a best-estimate fashion, the critical condition after a long decay period for a lattice primarily comprised of spent fuel assemblies. Results are also consistent with SCALE validation calculations performed based on experiments using mixed-oxide fuel rods in square lattice configurations 23 Hence one may conclude that the methodology applied in performing these reactor critical calculations is valid for performing criticality safety analyses for systems with spent fuel. 


\section{REFERENCES}

1. T. L. Sanders and R. M. Westfall, "Feasibility and Incentives for Burnup Credit in Spent Fuel Transport Casks," Nucl. Sci. Eng. 104 (1990).

2. "American National Standard for Nuclear Criticality Safety in Operations with Fissionable Materials Outside Reactors," ANSI/ANS-8.1-1983.

3. SCALE: A Modular Code System for Performing Standardized Computer Analyses for Licensing Evaluation, NUREG/CR-0200, Rev. 4 (ORNL/NUREG/CSD-2/R4), Vols. I, II, and III (draft November 1993). Available from Radiation Shielding Information Center as CCC545 .

4. M. C. Brady and T. L. Sanders, "A Validated Methodology for Evaluating Burnup Credit in Spent Fuel Casks," Proc. of International Conference on Nuclear Criticality Safety, Christ Church, Oxford, United Kingdom, September 9-31, 1991.

5. O. W. Hermann and C. V. Parks, "SAS2H: A Coupled One-Dimensional Depletion and Shielding Analysis Code," Sect. S2 of SCALE: A Modular Code System for Performing Standardized Computer Analyses for Licensing Evaluation, NUREG/CR-0200, Rev. 5 (ORNL/NUREG/CSD-2/R5), Vols. 1, 2 and 3 (draft November 1993). Available from Radiation Shielding Information Center as CCC-545.

6. N. F. Landers and L. M. Petrie, "CSAS4: An Enhanced Criticality Safety Analysis Module with an Optimum Pitch Search Option," Sect. C4 of SCALE: A Modular Code System for Performing Standardized Computer Analyses for Licensing Evaluation, NUREG/CR-0200, Rev. 5 (ORNL/NUREG/CSD-2/R5), Vols. 1, 2 and 3 (draft November 1993). Available from Radiation Shielding Information Center as CCC-545.

7. L. M. Petrie and N. F. Landers, "KENO V.a: An Improved Monte Carlo Criticality Program with Supergrouping," Sect. F11 of SCALE: A Modular Code System for Performing Standardized Computer Analyses for Licensing Evaluation, NUREG/CR-0200, Rev. 4 (ORNL/NUREG/CSD-2/R4), Vols. I, II, and III (draft November 1993). Available from Radiation Shielding Information Center as CCC-545.

8. J.-P. Renier and C. V. Parks, "Reactor Critical Calculations for Validation of Burnup Credit Analysis Methods," Trans. Am. Nucl. Soc. 62, 308 (1990). 
9. O. W. Hermann and R. M. Westfall, "ORIGEN-S: A SCALE System Module to Calculate Fuel Depletion, Actinide Transmutation, Fission Product Buildup and Decay, and Associated Radiation Source Terms," Sect. F7 of SCALE: A Modular Code System for Performing Standardized Computer Analyses for Licensing Evaluation, NUREG/CR-0200, Rev. 5 (ORNL/NUREG/CSD-2/R5), Vols. 1, 2 and 3 (draft November 1993). Available from Radiation Shielding Information Center as CCC-545.

10. B. H. Wakeman and S. A. Ahmed, Evaluation of Burnup Creditfor Dry Storage Casks, EPRI NP-6494, Electric Power Research Institute (August 1989).

11. O. W. Hermann and M. C. Brady, Comparisons of SAS2H and CASMO-3 Benchmark $k_{\infty}$ Calculations for Reactor Fuel With and Without Burnable Poisons, ORNL/TM-12490, Martin Marietta Energy Systems, Inc., Oak Ridge Natl. Lab. (to be published).

12. B. L. Broadhead et al., Investigation of Nuclide Importance to Functional Requirements Related to Transport and Long-Term Storage of LWR Spent Fuel, ORNL/TM-12742, Martin Marietta Energy Systems, Inc., Oak Ridge Natl. Lab. (in press).

13. D. G. Napolitano and D. G. Adli, Burnup Credit Criticality Analysis Using Advanced Nodal Techniques, Yankee Atomic Electric Co., March 1992.

14. N. M. Greene, "BONAMI-S: Resonance Self-Shielding by the Bondarenko Method," Sect. F1 of SCALE: A Modular Code System for Performing Standardized Computer Analyses for Licensing Evaluation, NUREG/CR-0200, Rev. 5 (ORNL/NUREG/CSD-2/R5), Vols. 1, 2 and 3 (draft November 1993). Available from Radiation Shielding Information Center as CCC-545.

15. N. M. Greene, L. M. Petrie, and R. M. Westfall, "NITAWL-II: SCALE System Module for Performing Resonance Shielding and Working Library Production," Sect. F2 of SCALE: A Modular Code System for Performing Standardized Computer Analyses for Licensing Evaluation, NUREG/CR-0200, Rev. 5 (ORNL/NUREG/ CSD-2/R5), Vols. 1, 2 and 3 (draft November 1993). Available from Radiation Shielding Information Center as CCC-545.

16. N. M. Greene, "User's Guide for Utility Modules," Sect. M15 of SCALE: A Modular Code System for Performing Standardized Computer Analyses for Licensing Evaluation, NUREG/CR-0200, Rev. 5 (ORNL/NUREG/ CSD-2/R5), Vols. 1, 2 and 3 (draft November 1993). Available from Radiation Shielding Information Center as CCC-545.

17. R. W. Carlson, Reactor Core Physics Design and Operating Data for Cycles 1, 2, and 3 of Surry Unit 1 PWR Power Plant, NP-79-2-LD, Georgia Institute of Technology, March 1979. 
18. O. W. Hermann, J-P. Renier, and C. V. Parks, Technical Support for a Proposed Decay Heat Guide Using SAS2H/ORIGEN-S Data, NUREG/CR-5625, ORNL/CSD-130, Martin Marietta Energy Systems, Inc., Oak Ridge Natl. Lab. (to be published).

19. G. W. Morey, The Properties of Glass, 2nd ed., Reinhold, New York, 1954.

20. F. W. Walker, J. R. Parrington, and F. Feiner (revisors of edition), Nuclides and Isotopes, 14th ed., General Electric Co., San Jose, California, 1989.

21. N. M. Greene and L. M. Petrie, "XSDRNPM-S: A One-Dimensional Discrete-Ordinates Code for Transport Analysis," Sect. F3 of SCALE: A Modular Code System for Performing Standardized Computer Analyses for Licensing Evaluation, NUREG/CR-0200, Rev. 4 (ORNL/NUREG/CSD-2/R4), Vols. I, II, and III (draft November 1993). Available from Radiation Shielding Information Center as CCC-545.

22. S. E. Turner, "An Uncertainty Analysis-Axial Burnup Distribution Effects," Proc. Workshop Use of Burnup Credit in Spent Fuel Transport Casks, Washington, D.C., February 21-22, 1988, T. L. Sanders, Ed., SAND89-0018, TTC-0884, UC-820, Sandia National Laboratories, October 1989.

23. S. M. Bowman and M. D. DeHart, "Validation of SCALE-4 for Burnup Credit Applications," Accepted for publication in Nuclear Technology. 


\section{APPENDIX A}

\section{SURRY UNIT 1 CYCLE 2 DATA}

The initial core loading pattern of Cycle 2 is shown in Fig. A.1. The initial and final burnup distributions in the core for Cycle 2 are listed in Table A.1. The assemblies are grouped in the table into the eighth-core symmetric sets as loaded in Cycle 2. 
ORNL-DWG 94M-6380

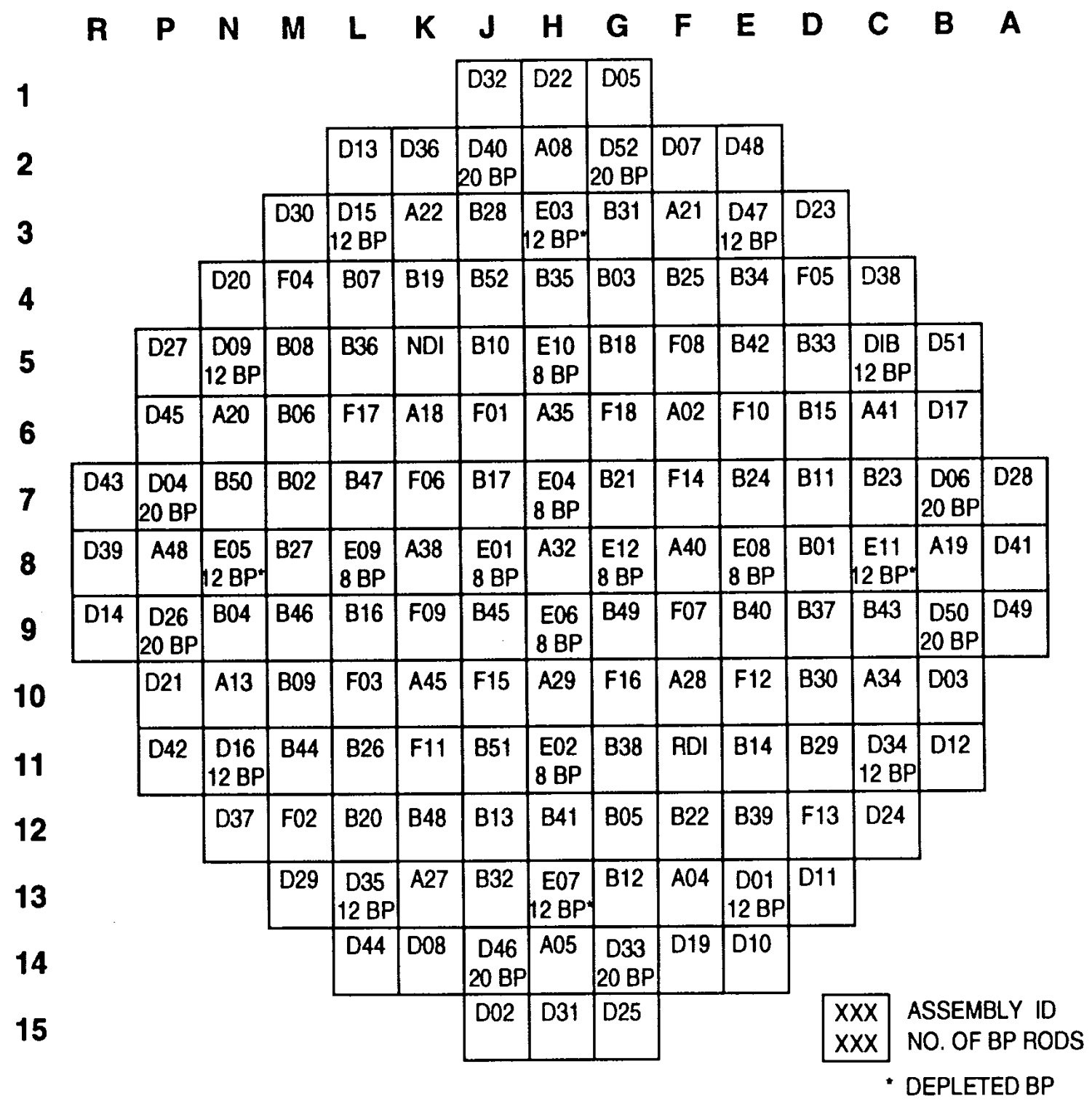

Fig. A.1. Surry Unit 1 Cycle 2 core loading pattern. 
Table A.1. Fuel assembly burnups at BOC and EOC for Surry Unit 1 Cycle 2

\begin{tabular}{|c|c|c|c|c|c|c|c|}
\hline \multirow{2}{*}{$\begin{array}{c}\text { Assembly } \\
\text { ID } \\
\end{array}$} & \multirow[b]{2}{*}{ Batch } & \multicolumn{2}{|c|}{$\begin{array}{c}\text { Burnup } \\
(\mathrm{MWd} / \mathrm{MTU}) \\
\end{array}$} & \multirow{2}{*}{$\begin{array}{c}\text { Assembly } \\
\text { ID } \\
\end{array}$} & \multirow[b]{2}{*}{ Batch } & \multicolumn{2}{|c|}{$\begin{array}{c}\text { Burnup } \\
\text { (MWd/MTU) }\end{array}$} \\
\hline & & $\mathrm{BOC}$ & $\mathrm{EOC}$ & & & $\mathrm{BOC}$ & EOC \\
\hline A02 & $1 \mathrm{~A} 2$ & 11475 & 18471 & B04 & 2 & 14439 & 21474 \\
\hline A18 & $1 \mathrm{~A} 2$ & 11512 & 18439 & B12 & 2 & 14347 & 21435 \\
\hline A28 & $1 \mathrm{~A} 2$ & 11539 & 18403 & B23 & 2 & 13891 & 21066 \\
\hline \multirow[t]{2}{*}{ A45 } & $1 \mathrm{~A} 2$ & 11686 & 18690 & B28 & 2 & 14578 & 21571 \\
\hline & & & & B31 & 2 & 14479 & 21412 \\
\hline A29 & $1 \mathrm{~A} 2$ & 12431 & 19389 & B32 & 2 & 14462 & 21634 \\
\hline A35 & $1 \mathrm{~A} 2$ & 12348 & 19417 & B43 & 2 & 14467 & 21542 \\
\hline A38 & $1 \mathrm{~A} 2$ & 12779 & 19859 & B50 & 2 & 14302 & 21285 \\
\hline \multirow[t]{2}{*}{ A40 } & $1 \mathrm{~A} 2$ & 12582 & 19722 & & & & \\
\hline & & & & B02 & 2 & 15479 & 22472 \\
\hline A04 & $1 \mathrm{~A} 2$ & 14084 & 19806 & B03 & 2 & 15972 & 22922 \\
\hline A13 & $1 \mathrm{~A} 2$ & 14098 & 19821 & B05 & 2 & 15833 & 22725 \\
\hline A20 & $1 \mathrm{~A} 2$ & 14119 & 19821 & B11 & 2 & 15870 & 22932 \\
\hline A21 & $1 \mathrm{~A} 2$ & 14317 & 20026 & B13 & 2 & 15849 & 22847 \\
\hline A22 & $1 \mathrm{~A} 2$ & 14402 & 20191 & B37 & 2 & 15749 & 22668 \\
\hline A27 & $1 \mathrm{~A} 2$ & 14182 & 19971 & B46 & 2 & 16039 & 23043 \\
\hline A34 & $1 \mathrm{~A} 2$ & 14222 & 19941 & B52 & 2 & 15855 & 22732 \\
\hline \multirow[t]{2}{*}{ A41 } & $1 \mathrm{~A} 2$ & 14072 & 19935 & & & & \\
\hline & & & & B06 & 2 & 15842 & 22614 \\
\hline A05 & $1 \mathrm{~A} 2$ & 14439 & 20165 & B09 & 2 & 15857 & 22604 \\
\hline A08 & $1 \mathrm{~A} 2$ & 14688 & 20192 & B15 & 2 & 16094 & 22841 \\
\hline A19 & $1 \mathrm{~A} 2$ & 14997 & 20667 & B19 & 2 & 15708 & 22468 \\
\hline \multirow[t]{2}{*}{ A48 } & $1 \mathrm{~A} 2$ & 14933 & 20602 & B22 & 2 & 15539 & 22245 \\
\hline & & & & B25 & 2 & 15804 & 22635 \\
\hline \multirow[t]{2}{*}{ A32 } & $1 \mathrm{~A} 2$ & 15316 & 22094 & B30 & 2 & 15921 & 22521 \\
\hline & & & & B48 & 2 & 15530 & 22348 \\
\hline B10 & 2 & 14437 & 21981 & & & & \\
\hline B16 & 2 & 13886 & 21697 & B07 & 2 & 16403 & 23111 \\
\hline B18 & 2 & 14150 & 21947 & B08 & 2 & 16255 & 22974 \\
\hline B24 & 2 & 14069 & 21956 & B20 & 2 & 16175 & 22914 \\
\hline B38 & 2 & 14064 & 21759 & B29 & 2 & 16178 & 22848 \\
\hline B40 & 2 & 14175 & 21920 & B33 & 2 & 16439 & 22985 \\
\hline B47 & 2 & 14173 & 21920 & B34 & 2 & 16444 & 23140 \\
\hline \multirow[t]{2}{*}{ B51 } & 2 & 14066 & 21849 & B39 & 2 & 16136 & 22857 \\
\hline & & & & B44 & 2 & 16354 & 23080 \\
\hline
\end{tabular}


Table A.1. (continued)

\begin{tabular}{|c|c|c|c|c|c|c|c|}
\hline \multirow{2}{*}{$\begin{array}{c}\text { Assembly } \\
\text { ID } \\
\end{array}$} & \multirow[b]{2}{*}{ Batch } & \multicolumn{2}{|c|}{$\begin{array}{c}\text { Burnup } \\
\text { (MWd/MTU) }\end{array}$} & \multirow{2}{*}{$\begin{array}{c}\text { Assembly } \\
\text { ID } \\
\end{array}$} & \multirow[b]{2}{*}{ Batch } & \multicolumn{2}{|c|}{$\begin{array}{c}\text { Burnup } \\
\text { (MWd/MTU) }\end{array}$} \\
\hline & & $\mathrm{BOC}$ & EOC & & & BOC & EOC \\
\hline B01 & 2 & 15439 & 22989 & E03 & 4BB & 0 & 8271 \\
\hline B27 & 2 & 15549 & 23032 & E05 & 4BB & 0 & 8492 \\
\hline B35 & 2 & 14992 & 22344 & E07 & $4 \mathrm{BB}$ & 0 & 8349 \\
\hline B41 & 2 & 14914 & 22315 & E11 & $4 \mathrm{BB}$ & 0 & 8602 \\
\hline B14 & 2 & 16522 & 23426 & E02 & $4 \mathrm{BF}$ & 0 & 8329 \\
\hline B26 & 2 & 16610 & 23550 & E08 & $4 \mathrm{BF}$ & 0 & 8499 \\
\hline B36 & 2 & 16634 & 23636 & E09 & $4 \mathrm{BF}$ & 0 & 8413 \\
\hline B42 & 2 & 16582 & 23525 & E10 & $4 \mathrm{BF}$ & 0 & 8249 \\
\hline B17 & 2 & 16315 & 24286 & E01 & $4 \mathrm{BF}$ & 0 & 8734 \\
\hline B21 & 2 & 16426 & 24344 & E04 & $4 \mathrm{BF}$ & 0 & 8695 \\
\hline B45 & 2 & 16413 & 24258 & E06 & $4 \mathrm{BF}$ & 0 & 8533 \\
\hline B49 & 2 & 15965 & 23686 & E12 & $4 \mathrm{BF}$ & 0 & 8592 \\
\hline F02 & $4 \mathrm{~A}$ & 0 & 6948 & D02 & $4 \mathrm{CN}$ & 0 & 5203 \\
\hline F04 & $4 \mathrm{~A}$ & 0 & 6850 & D05 & $4 \mathrm{CN}$ & 0 & 4815 \\
\hline F05 & $4 \mathrm{~A}$ & 0 & 6789 & D14 & $4 \mathrm{CN}$ & 0 & 5163 \\
\hline \multirow[t]{2}{*}{ F13 } & $4 \mathrm{~A}$ & 0 & 6945 & D25 & $4 \mathrm{CN}$ & 0 & 5280 \\
\hline & & & & D32 & $4 \mathrm{CN}$ & 0 & 4998 \\
\hline F03 & $4 \mathrm{~A}$ & 0 & 7642 & D43 & $4 \mathrm{CN}$ & 0 & 5163 \\
\hline F08 & $4 \mathrm{~A}$ & 0 & 7671 & D49 & $4 \mathrm{CN}$ & 0 & 5068 \\
\hline F10 & $4 \mathrm{~A}$ & 0 & 7622 & D28 & $4 \mathrm{CN}$ & 0 & 5108 \\
\hline F11 & $4 \mathrm{~A}$ & 0 & 7651 & & & & \\
\hline F12 & $4 \mathrm{~A}$ & 0 & 7492 & D10 & $4 \mathrm{CN}$ & 0 & 5407 \\
\hline F17 & $4 \mathrm{~A}$ & 0 & 7558 & D12 & $4 \mathrm{CN}$ & 0 & 5531 \\
\hline ND1 & $4 X$ & 0 & 7540 & D13 & $4 \mathrm{CN}$ & 0 & 5471 \\
\hline \multirow[t]{2}{*}{ RD1 } & $4 X$ & 0 & 7613 & D27 & $4 \mathrm{CN}$ & 0 & 5483 \\
\hline & & & & D42 & $4 \mathrm{CN}$ & 0 & 5534 \\
\hline F01 & $4 \mathrm{~A}$ & 0 & 8042 & D44 & $4 \mathrm{CN}$ & 0 & 5485 \\
\hline F06 & $4 \mathrm{~A}$ & 0 & 8112 & D48 & $4 \mathrm{CN}$ & 0 & 5377 \\
\hline F07 & $4 \mathrm{~A}$ & 0 & 7948 & D51 & $4 \mathrm{CN}$ & 0 & 5773 \\
\hline F09 & $4 \mathrm{~A}$ & 0 & 8098 & & & & \\
\hline F14 & $4 \mathrm{~A}$ & 0 & 8202 & D22 & $4 \mathrm{CN}$ & 0 & 6155 \\
\hline F15 & $4 \mathrm{~A}$ & 0 & 8093 & D31 & $4 \mathrm{CN}$ & 0 & 6572 \\
\hline F16 & $4 \mathrm{~A}$ & 0 & 7896 & D39 & $4 \mathrm{CN}$ & 0 & 6483 \\
\hline F18 & $4 \mathrm{~A}$ & 0 & 8172 & D41 & $4 \mathrm{CN}$ & 0 & 6380 \\
\hline
\end{tabular}


Table A.1. (continued)

\begin{tabular}{|c|c|c|c|c|c|c|c|}
\hline \multirow{2}{*}{$\begin{array}{c}\text { Assembly } \\
\text { ID }\end{array}$} & \multirow[b]{2}{*}{ Batch } & \multicolumn{2}{|c|}{$\begin{array}{c}\text { Burnup } \\
(\mathrm{MWd} / \mathrm{MTU})\end{array}$} & \multirow{2}{*}{$\begin{array}{c}\text { Assembly } \\
\text { ID }\end{array}$} & \multirow[b]{2}{*}{ Batch } & \multicolumn{2}{|c|}{$\begin{array}{c}\text { Burnup } \\
\text { (MWd/MTU) }\end{array}$} \\
\hline & & BOC & EOC & & & BOC & EOC \\
\hline D11 & $4 \mathrm{CN}$ & 0 & 6107 & D04 & $4 \mathrm{CF}$ & 0 & 6482 \\
\hline D20 & $4 \mathrm{CN}$ & 0 & 6018 & D26 & $4 \mathrm{CF}$ & 0 & 6493 \\
\hline D23 & $4 \mathrm{CN}$ & 0 & 6040 & D40 & $4 \mathrm{CF}$ & 0 & 6350 \\
\hline D24 & $4 \mathrm{CN}$ & 0 & 6068 & D52 & $4 \mathrm{CF}$ & 0 & 6221 \\
\hline D29 & $4 \mathrm{CN}$ & 0 & 6108 & D06 & $4 \mathrm{CF}$ & 0 & 6600 \\
\hline D30 & $4 \mathrm{CN}$ & 0 & 6016 & D33 & $4 \mathrm{CF}$ & 0 & 6706 \\
\hline D37 & $4 \mathrm{CN}$ & 0 & 6172 & D46 & $4 \mathrm{CF}$ & 0 & 6533 \\
\hline D38 & $4 \mathrm{CN}$ & 0 & 6044 & D50 & $4 \mathrm{CF}$ & 0 & 6509 \\
\hline D03 & $4 \mathrm{CN}$ & 0 & 7379 & D01 & $4 \mathrm{CF}$ & 0 & 7410 \\
\hline D07 & $4 \mathrm{CN}$ & 0 & 7046 & D15 & $4 \mathrm{CF}$ & 0 & 7439 \\
\hline D08 & $4 \mathrm{CN}$ & 0 & 7428 & D16 & $4 \mathrm{CF}$ & 0 & 7485 \\
\hline D17 & $4 \mathrm{CN}$ & 0 & 7610 & D18 & $4 \mathrm{CF}$ & 0 & 7433 \\
\hline D19 & $4 \mathrm{CN}$ & 0 & 7464 & D09 & $4 \mathrm{CF}$ & 0 & 7417 \\
\hline D21 & $4 \mathrm{CN}$ & 0 & 7246 & D34 & $4 \mathrm{CF}$ & 0 & 7435 \\
\hline D36 & $4 \mathrm{CN}$ & 0 & 7278 & D35 & $4 \mathrm{CF}$ & 0 & 7419 \\
\hline D45 & $4 \mathrm{CN}$ & 0 & 7219 & D47 & $4 \mathrm{CF}$ & 0 & 7390 \\
\hline
\end{tabular}




\section{APPENDIX B}

\section{SAS2H CASE INPUT EXAMPLE}

This appendix gives an example of one of the nine SAS2H cases. It gives a list of the JCL and data for SAS2H batch 4BF. 


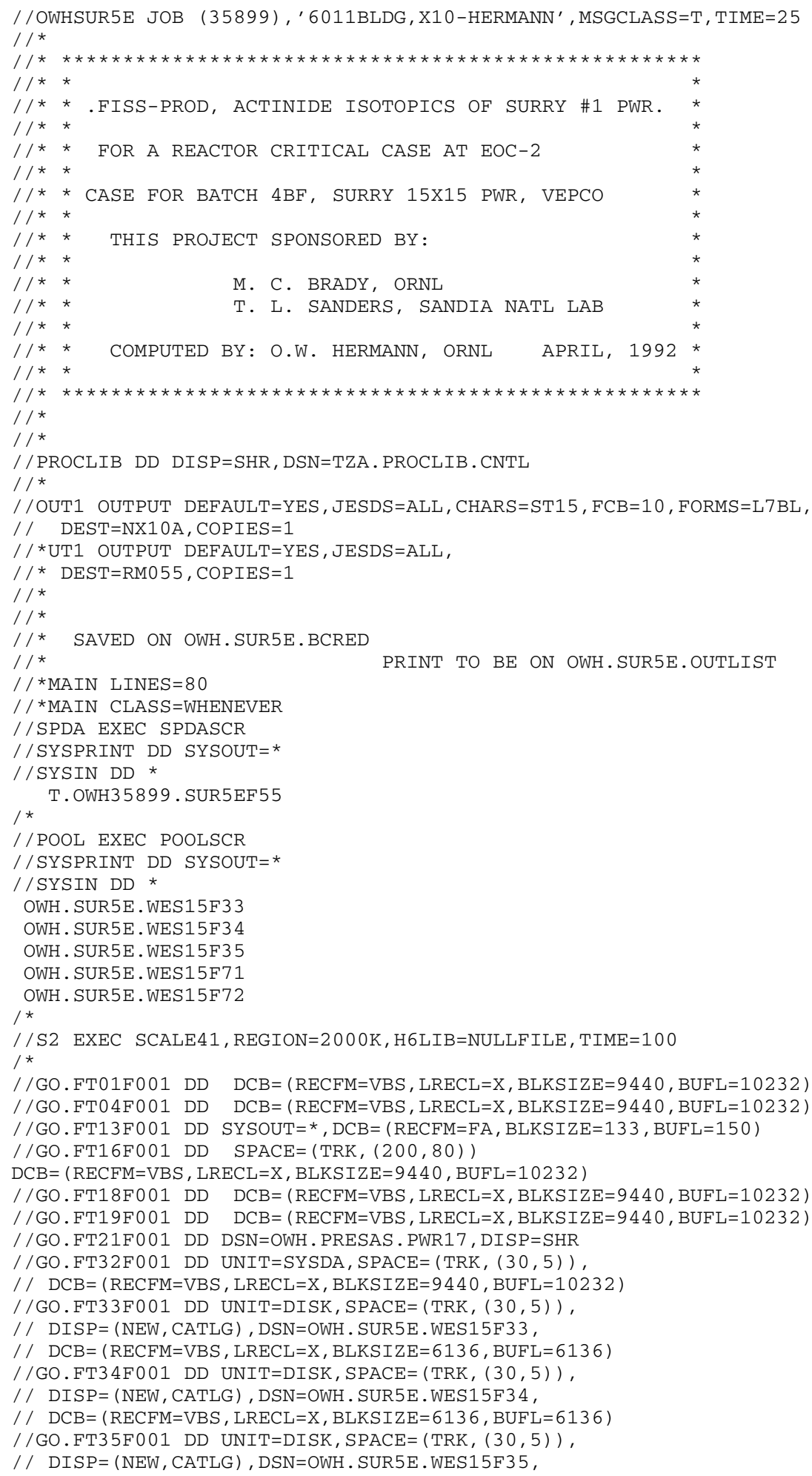




\section{8}

/ / $\mathrm{DCB}=(\mathrm{RECFM}=\mathrm{VBS}, \mathrm{LRECL}=\mathrm{X}, \mathrm{BLKSIZE}=6136, \mathrm{BUFL}=6136)$

//* NOTE ABOVE BLOCKSIZE/BUFL CHANGED TO SCALE DEFAULT.....

//GO.FT70F001 DD SPACE $=($ TRK, $(10,8)), \mathrm{UNIT}=\mathrm{SYSDA}$,

/ / $\mathrm{DCB}=(\mathrm{RECFM}=\mathrm{VBS}, \mathrm{LRECL}=\mathrm{X}, \mathrm{BLKSIZE}=9440, \mathrm{BUFL}=10232)$

//GO.FT71F001 DD UNIT=DISK, SPACE $=($ TRK, $(20,5))$,

// DISP $=(\mathrm{NEW}, \mathrm{CATLG}), \mathrm{DSN}=\mathrm{OWH} . \mathrm{SUR} 5 \mathrm{E} . \mathrm{WES} 15 \mathrm{~F} 71$,

/ / $\mathrm{DCB}=(\mathrm{RECFM}=\mathrm{VBS}, \mathrm{LRECL}=\mathrm{X}, \mathrm{BLKSIZE}=9440, \mathrm{BUFL}=10232)$

//GO.FT72F001 DD UNIT $=$ DISK, $\operatorname{SPACE}=($ TRK, $(10,5))$,

// $\mathrm{DCB}=(\mathrm{RECFM}=\mathrm{FB}, \mathrm{LRECL}=80, \mathrm{BLKSIZE}=6400)$,

// DISP = (NEW, CATLG) , DSN=OWH . SUR5E. WES15F72

//GO.FT74F001 DD UNIT=SYSDA,

// $\operatorname{SPACE}=(800,(2,2), \mathrm{RLSE}), \mathrm{DCB}=(\mathrm{RECFM}=\mathrm{FB}, \mathrm{LRECL}=80, \mathrm{BLKSIZE}=800)$

$/ /$ GO.FT53F001 DD UNIT $=$ SYSDA, SPACE $=($ TRK, $(90,5))$,

/ / $\mathrm{DCB}=(\mathrm{RECFM}=\mathrm{VBS}, \mathrm{LRECL}=\mathrm{X}, \mathrm{BLKSIZE}=3664, \mathrm{BUFL}=4088)$

$/ /$ GO.FT55F001 DD UNIT=SPDA, $\operatorname{SPACE}=(T R K,(2,1))$,

/ / $\mathrm{DCB}=(\mathrm{RECFM}=\mathrm{VBS}, \mathrm{LRECL}=\mathrm{X}, \mathrm{BLKSIZE}=3664, \mathrm{BUFL}=4088)$,

// DISP $=($ NEW, CATLG $), \mathrm{DSN}=\mathrm{T}$. OWH35899. SUR5EF55

//GO.SYSIN DD *

$=$ SAS2 PARM $=$ 'HALT03, SKIPSHIPDATA'

SAS2H: SURRY CRITICAL ISOTOPICS, BATCH 4BF, 4 GWD/MTU INT, X 3 CYCLES 27BURNUPLIB LATTICECELL

MIXTURES OF FUEL-PIN-UNIT-CELL:

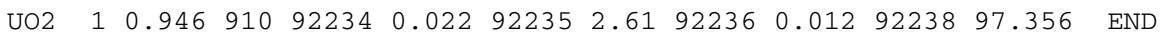

$\begin{array}{llllll}\mathrm{KR}-83 & 1 & 0 & 1-20 & 910 & \mathrm{END}\end{array}$

KR-85 $10 \begin{array}{lllll}1-20 & 910 & \text { END }\end{array}$

SR-90 $10 \begin{array}{lllll}1 & 0 & 1-20 & 910 & \text { END }\end{array}$

$\begin{array}{rlllll}\mathrm{Y}-89 & 1 & 0 & 1-20 & 910 & \mathrm{END}\end{array}$

MO-95 $11001-20 \quad 910$ END

ZR-93 $11001-20 \quad 910 \quad$ END

ZR-94 $10 \begin{array}{lllll} & 1-20 & 910 & \text { END }\end{array}$

$\begin{array}{lllllll}Z R-95 & 1 & 0 & 1-20 & 910 & \text { END }\end{array}$

NB-94 $101-20 \quad 910$ END

$\begin{array}{lllllll}\text { TC-99 } & 1 & 0 & 1-20 & 910 & \text { END }\end{array}$

RH-103 $1001-20 \quad 910$ END

RH-105 $10 \begin{array}{lllll}1 & 0 & 1-20 & 910 & \text { END }\end{array}$

RU-101 $10 \begin{array}{lllll}1-20 & 910 & \text { END }\end{array}$

RU-106 $101-20 \quad 910$ END

$\begin{array}{lllllll}P D-105 & 1 & 0 & 1-20 & 910 & \text { END }\end{array}$

PD-108 $11001-20 \quad 910$ END

AG-109 $1001-20 \quad 910$ END

SB-124 $1001-20 \quad 910$ END

$\begin{array}{llllll}I-135 & 1 & 0 & 1-20 & 910 & \text { END }\end{array}$

$\begin{array}{llllll}\mathrm{XE}-131 & 1 & 0 & 1-20 & 910 & \mathrm{END}\end{array}$

XE-132 $1001-20 \quad 910$ END

$\begin{array}{llllll}\mathrm{XE}-135 & 1 & 0 & 6-9 & 910 & \mathrm{END}\end{array}$

$\begin{array}{lllllll}\mathrm{XE}-136 & 1 & 0 & 1-20 & 910 & \mathrm{END}\end{array}$

CS-134 $1001-20 \quad 910$ END

CS-135 $1001-20 \quad 910$ END

CS-137 $1001-20 \quad 910$ END

BA-136 $1001-20 \quad 910$ END

LA-139 $11001-20 \quad 910$ END

$\begin{array}{llllll}\mathrm{PR}-141 & 1 & 0 & 1-20 & 910 & \text { END }\end{array}$

PR-143 $1001-20 \quad 910$ END

CE-144 $1001-20 \quad 910$ END

ND-143 $11001-20 \quad 910$ END

ND-145 $11001-20 \quad 910$ END

PM-147 $11001-20 \quad 910 \quad$ END

PM-148 $11001-20 \quad 910$ END

$\begin{array}{lllllll}\text { PM-149 } 14 & 0 & 1-20 & 910 & \text { END }\end{array}$

ND-147 $101-20 \quad 910$ END

SM-147 $11001-20 \quad 910 \quad$ END

SM-149 $11001-20 \quad 910$ END

SM-150 $1001-20 \quad 910$ END

SM-151 $11001-20 \quad 910$ END 


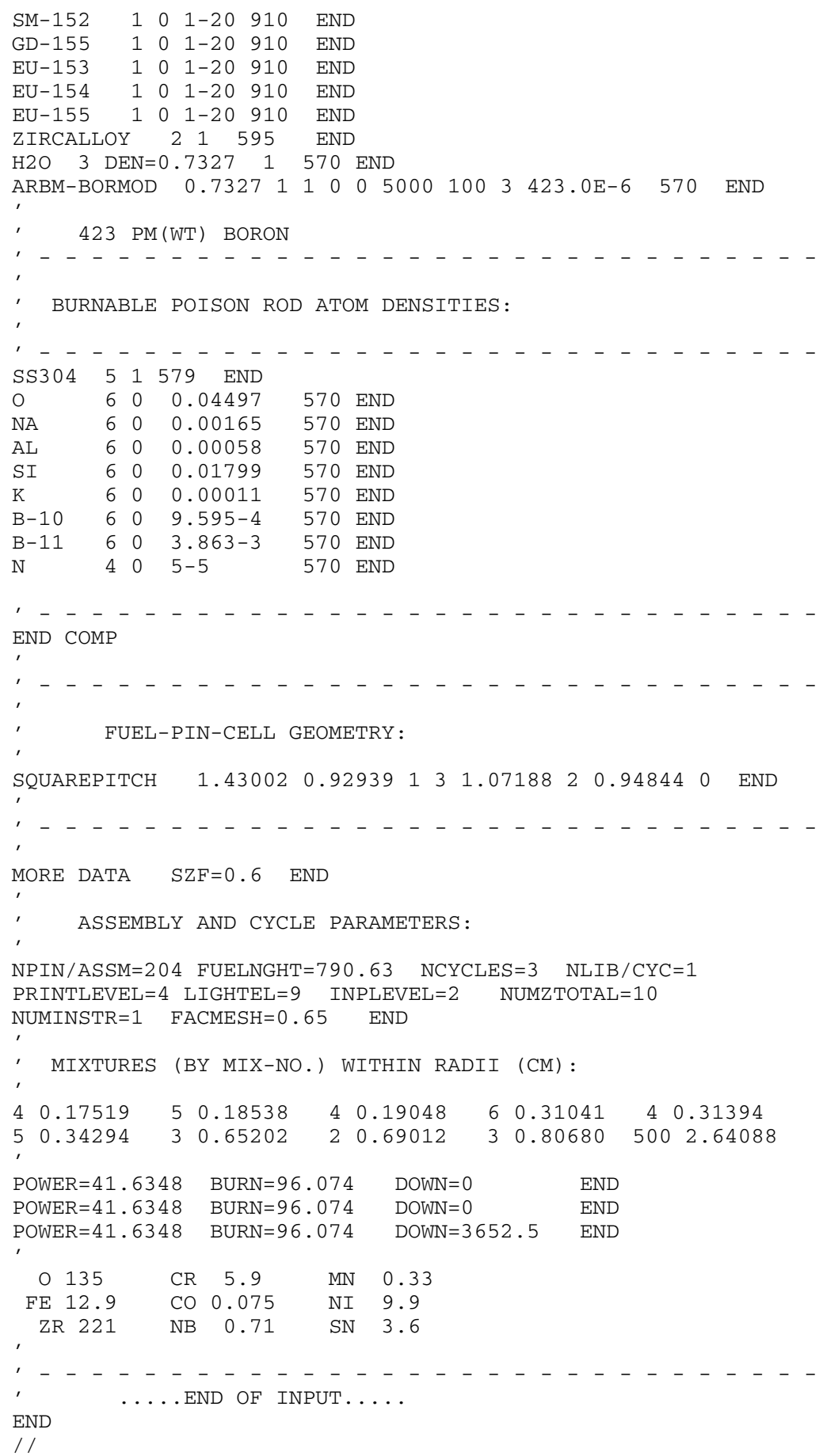




\section{APPENDIX C \\ SNIKR VERSION 1.0 DOCUMENTATION}

This appendix includes a User's Input Guide, FORTRAN Listings, and Sample Output. 


\section{SNIKR VERSION 1.0 USER'S INPUT GUIDE}

Each entry below must begin in column 1. Recommended values are given in parentheses.

Line 1

SNIKR1

Line 2

Title card for SNIKR1 (80-character maximum)

Line 3

READ BURNUP

Line 4

$\mathrm{N} 72=\mathrm{ii}$ (I2 format)

Unit number for SAS2H atom density file (72)

Line $5 \quad$ NOUT=ii (I2 format)

Unit number for SNIKR1 output file (70)

Line $6 \quad$ BURN=xxxxxx.x (F8.1 format)

Desired burnup in MWd/MTU for interpolation

Line $7 \quad$ NCYC=ii (I2 format)

Number of cycles in SAS2H depletion

Line 8

END BURNUP

Line 9

READ DECAY

Line $10 \quad$ NORS=ii (I2 format)

Unit number for ORIGEN-S input file created by SNIKR1 (74)

Line $11 \quad$ N71=ii (I2 format)

Unit number to which ORIGEN-S will write the restart file containing the isotopic data at the requested cooling times. This file will then be read by SNIKR3 (71)

Line 12 COOLTME=xxx.xx (F6.2 format)

Cooling time in years at which isotopics are desired 
Line $13 \quad$ LIGHTEL=ii (I2 format)

Number of light element nuclides for which isotopics are desired. Data will be read after "END DECAY." This option allows the user to extract light element data in addition to actinide and fission-product data and/or to adjust the concentrations of light-element nuclides.

Line 14

END DECAY

If LIGHTEL > 0, enter the following data for each light-element nuclide (free format):

a. Nuclide ID number

b. Atom density of nuclide

c. Option flag

$1=$ replace $\mathrm{SAS} 2 \mathrm{H}$ atom density with value entered above

$2=$ replace $\mathrm{SAS} 2 \mathrm{H}$ atom density only if $\mathrm{SAS} 2 \mathrm{H}$ value is zero

$3=$ add the atom density to the SAS2H value. Using this option and an atom density of zero above will extract data from SAS2H without modification.

Line $15 \quad$ SNIKR3

Line 16 Title card for SNIKR3 (80-character maximum)

Line $17 \quad$ READ MXFUEL

Line $18 \quad$ N71=ii (I2 format)

Unit number from which SNIKR3 will read the ORIGEN-S restart file containing the isotopic data at the requested cooling times (71)

Line $19 \quad$ NICE=ii (I2 format)

Unit number to which SNIKR3 writes the data for input to ICE (75)

Line $20 \quad$ NOUT3=ii (I2 format)

Unit number to which SNIKR3 writes the data in SCALE standard composition and KENO V.a mixing table input formats (73)

Line $21 \quad$ NCOOL=ii (I2 format)

Cooling time step in ORIGEN-S output from which isotopic data are to be extracted

Line $22 \quad$ FISPROD=iii (I3 format)

Actinide and fission-product nuclides for which isotopic data are to be extracted 
$0=25$ burnup credit nuclides from ref. 4

$-1=37$ burnup credit nuclides from ref. 1

$-2=48$ nuclides used in reactor critical calculations (Table 2)

$-3=193$ nuclides (all nuclides in 27-group burnup library)

$\mathrm{N}=$ Read $\mathrm{N}$ nuclides specified by user after "END MXFUEL"

Line 23 MIXF=iiii (I4 format)

Mixture number for SCALE standard composition input

Line 24 IDMOD=ii (I2 format)

Fuel nuclide ID modifier for seven burnup-dependent actinides

Line 25 END MXFUEL

If FISPROD > 0, enter the nuclide IDs here. (Format 10(1X,I5)) 


\section{SNIKR1 FORTRAN Listing}

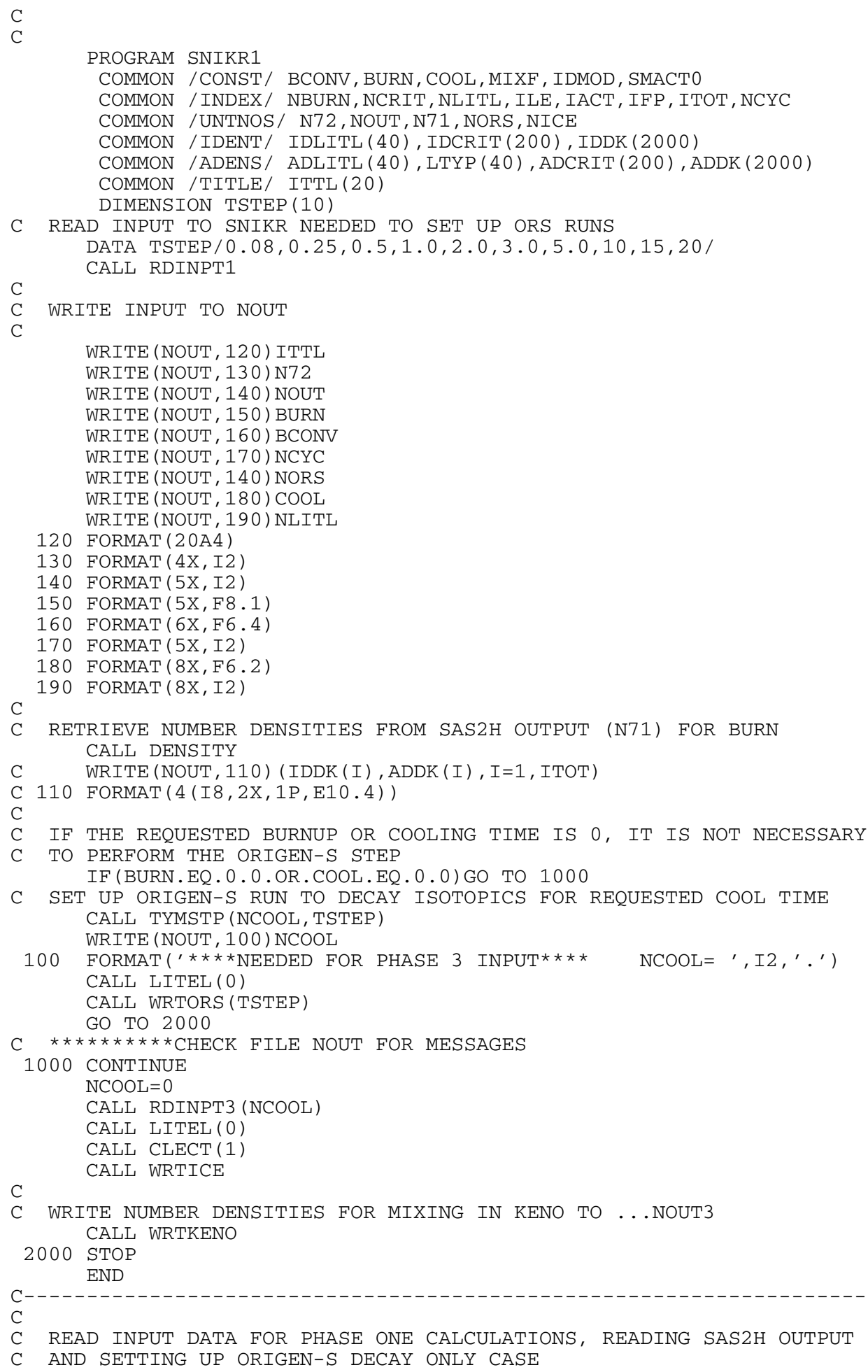




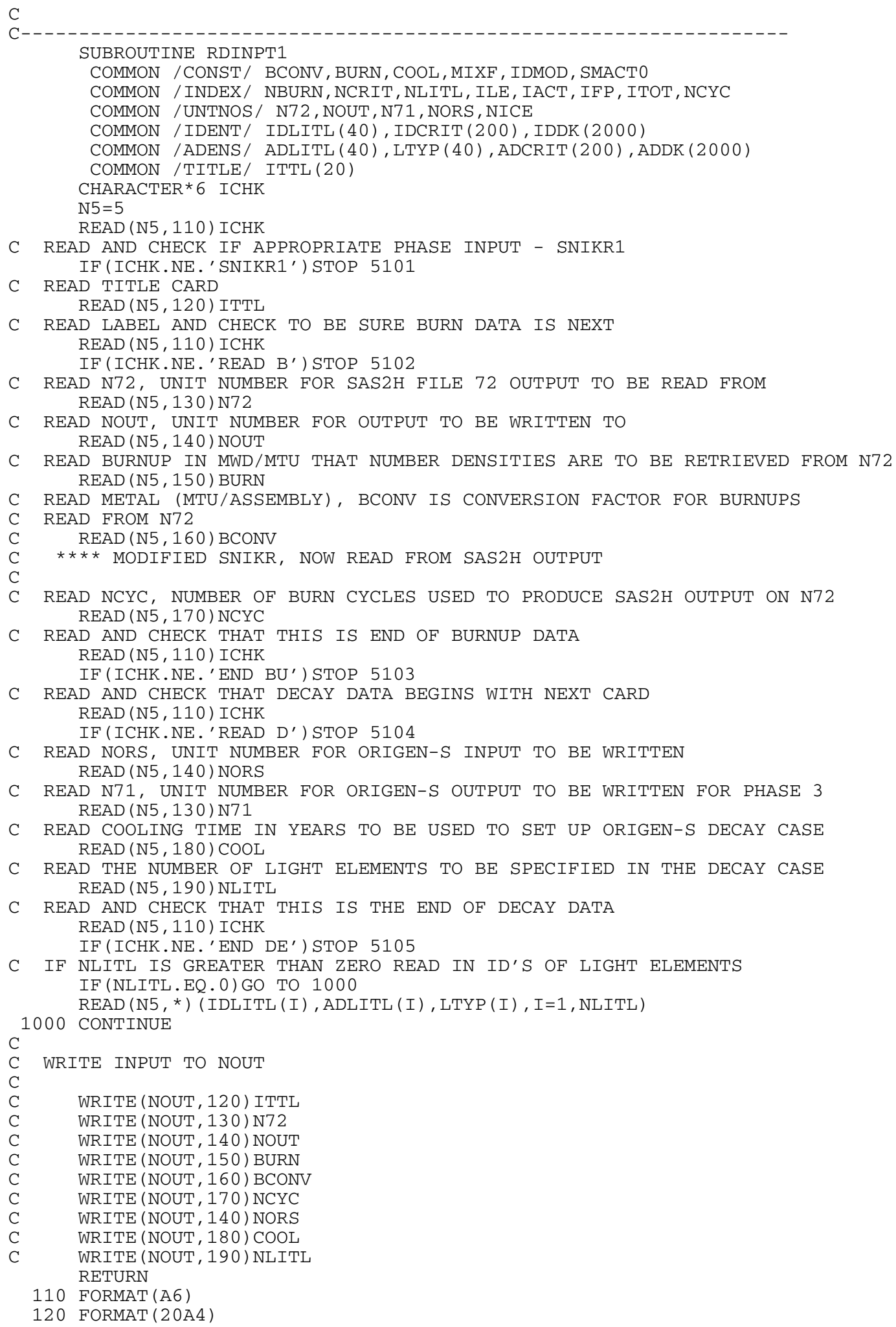




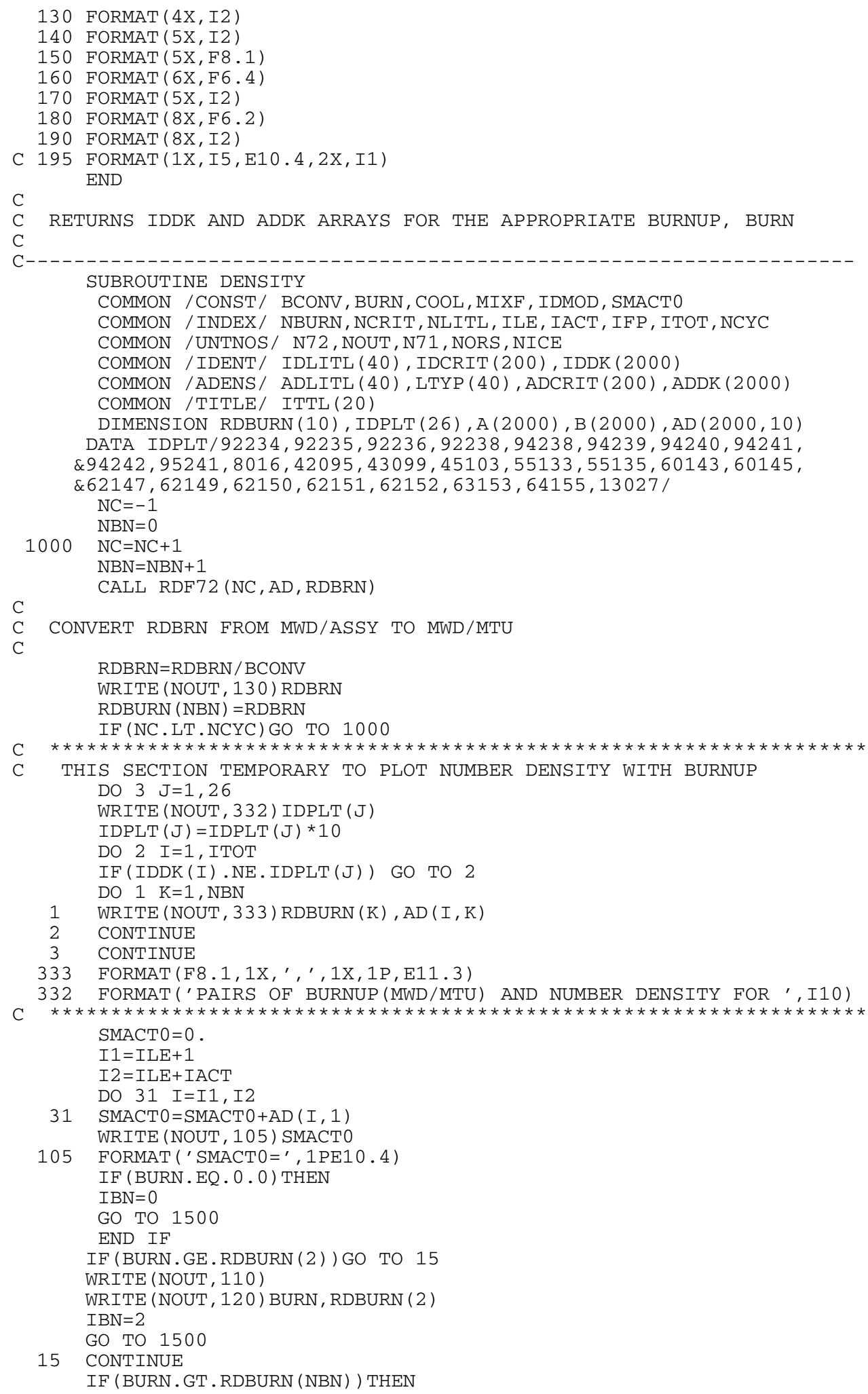




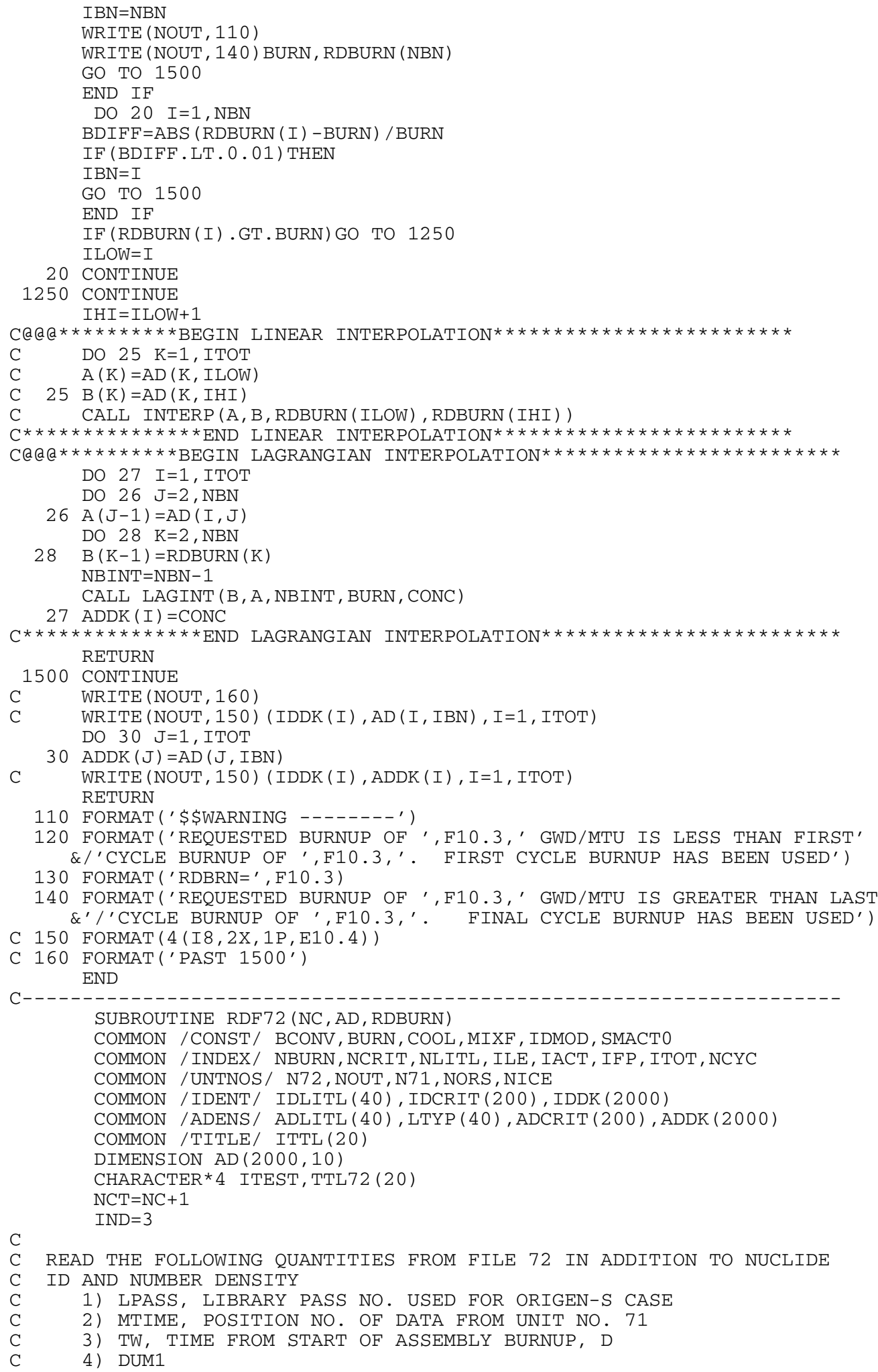


C 5) RDBURN, ACCUMULATED BURNUP AT TW, MWD/ASSEMBLY

C 6) SPWR, SPECIFIC POWER OF CYCLE, KW/KG U

C 7) DUM3

C

8) BCONV, INITIAL METRIC TON U WEIGHT PER ASSEMBLY

READ (N72 , 100 , END=2 000 ) LPASS , MTIME , TW , DUM1 , RDBURN, SPWR, DUM3 , BCONV IF (NCT.EQ.1) WRITE (NOUT, 99)

99 FORMAT (/,

\&/'1) LPASS, LIBRARY PASS NO. USED FOR ORIGEN-S CASE',

$\& / \prime 2)$ MTIME, POSITION NO. OF DATA FROM UNIT NO. 71',

$\& / \prime 3)$ TW, TIME FROM START OF ASSEMBLY BURNUP, D',

$\varepsilon /$ / 4) DUM1',

$\& /, 5)$ RDBURN, ACCUMULATED BURNUP AT TW, MWD/ASSEMBLY',

\&/'6) SPWR, SPECIFIC POWER OF CYCLE, KW/KG U',

$\& / \prime 7)$ DUM3',

\&/'8) BCONV, INITIAL METRIC TON U WEIGHT PER ASSEMBLY')

WRITE (NOUT, 100) LPASS, MTIME, TW, DUM1, RDBURN, SPWR, DUM3 , BCONV

IF ( LPASS . EQ . NCYC) IND=1

IF (LPASS.NE.NC) THEN

WRITE (NOUT, 101) NC, LPASS, NCYC

101 FORMAT ('NC=', I2,' LPASS $=$ ', I2,' $\mathrm{NCYC}=$ ',I2,' MTIME=',I2,' IND=', I2) STOP 7210

END IF

IF (MTIME.NE. IND) THEN

WRITE (NOUT, 101) NC, LPASS, NCYC, MTIME, IND

IF (NC.EQ.NCYC.AND. MTIME.EQ.3) GO TO 5

STOP 7220

END IF

5 CONTINUE

READ (N72, 110) ITOT, ILE, IACT, IFP

$I S U M=I L E+I A C T+I F P$

IF (ISUM.NE.ITOT) STOP 7230

DO $10 \quad I=1,4$

$10 \quad \operatorname{READ}(\mathrm{N} 72,140)$

$\operatorname{READ}(\mathrm{N} 72,120)$ ( IDDK (I), AD ( I , NCT) , I=1, ITOT)

C WRITE (NOUT, 102) NCT, LPASS, NCYC

C 102 FORMAT ('NCT=', I2,' LPASS $=$ ',I2,' NCYC=',I2,' AD ARRAY')

C WRITE (NOUT, 120) (IDDK (I) , AD (I, NCT), I=ILE, ILE+16)

READ (N72, 125) TTL72

WRITE (NOUT, 125) TTL72

C WRITE (NOUT, 160) RDBURN, NCT

1000 READ (N72,130) ITEST

IF (ITEST.NE.'----')GO TO 1000

RETURN

2000 CONTINUE

WRITE (NOUT, 150)

RETURN

100 FORMAT (2I10, 6 (1X, 1P, E9.3))

110 FORMAT (4I10)

120 FORMAT (4 (I8, 2X, 1P , E10.4))

125 FORMAT (20A4)

130 FORMAT (A4)

140 FORMAT ( )

150 FORMAT $(* * * *$ EOF ERROR READING FILE $72 * * * \prime)$

C 160 FORMAT ('RDBURN $(\mathrm{F} 72)=\prime, F 10.3, ' \mathrm{NCT}={ }^{\prime}, \mathrm{I} 2$ )

END

SUBROUTINE LAGINT (X, Y, N, XINT, YOUT)

C THIS SUBROUTINE PERFORMS LAGRANGIAN INTERPOLATION WITHIN A SET OF

$\mathrm{C}(\mathrm{X}, \mathrm{Y})$ PAIRS TO GIVE THE Y VALUE CORRESPONDING TO XINT. THE DEGREE OF

C THE INTERPOLATING POLYNOMIAL IS ONE LESS THAN THE NUMBER OF POINTS

C SUPPLIED. TAKEN FROM GERALD'S "APPLIED NUMERICAL ANALYSIS" PG 181

C PARAMETERS ARE:

$X$ - ARRAY OF VALUES OF THE INDEPENDENT VARIABLE

$\mathrm{Y}$ - ARRAY OF FUNCTION VALUES CORRESPONDING TO $\mathrm{X}$

$\mathrm{N}$ - NUMBER OF POINTS

XINT - THE X-VALUE FOR WHICH ESTIMATE OF Y IS DESIRED

YOUT - THE Y-VALUE RETURNED TO CALLER 


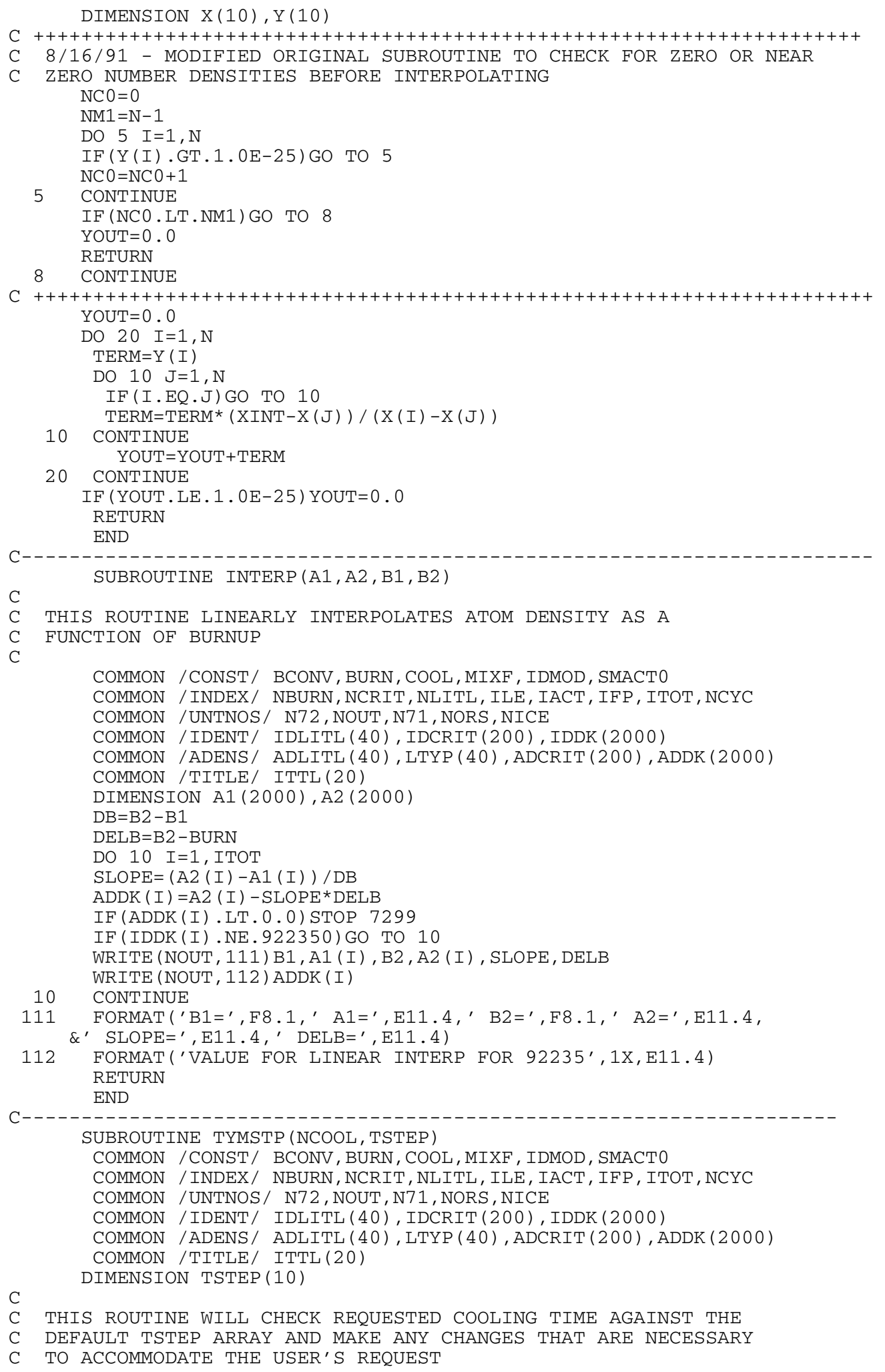




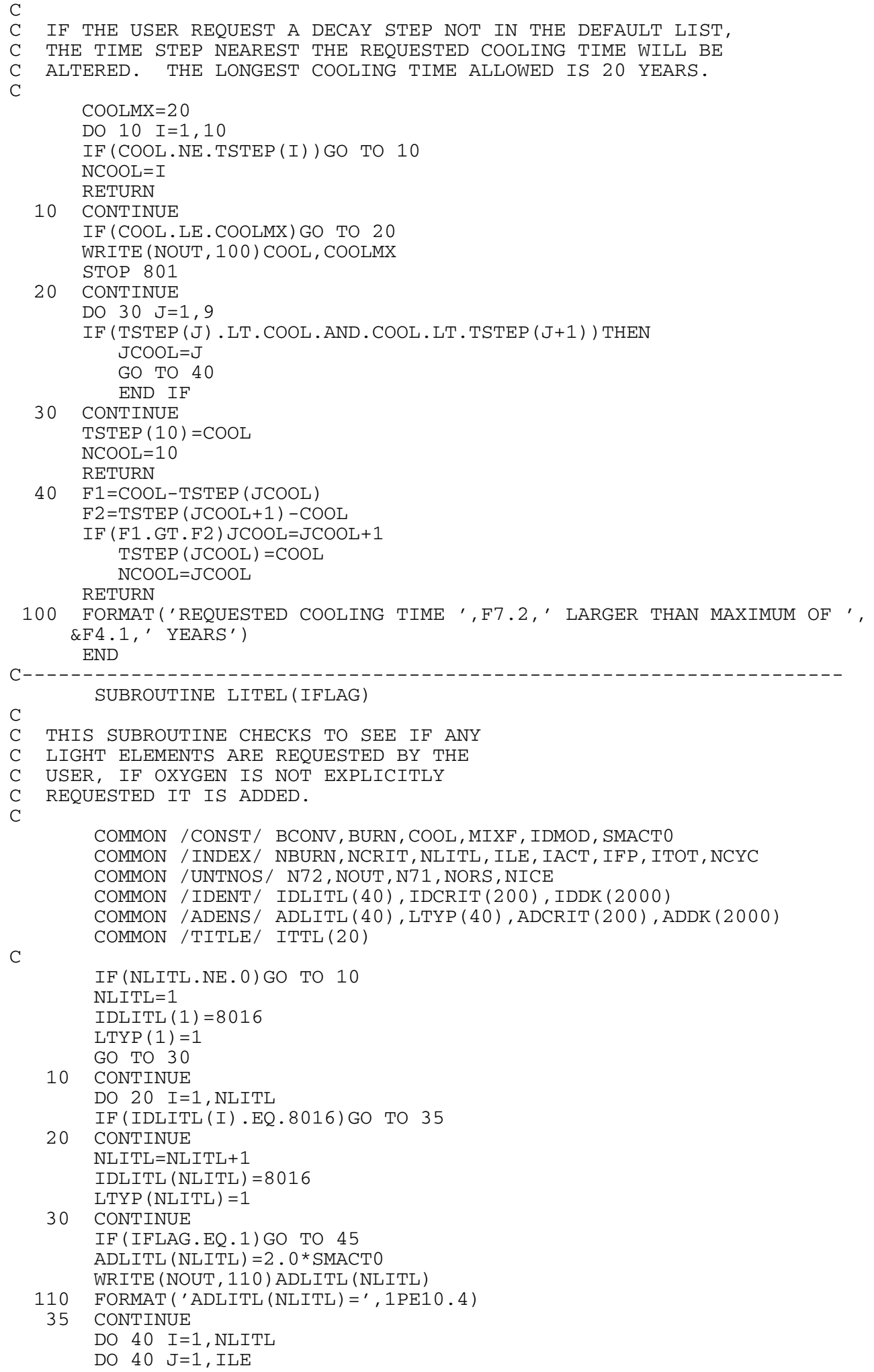




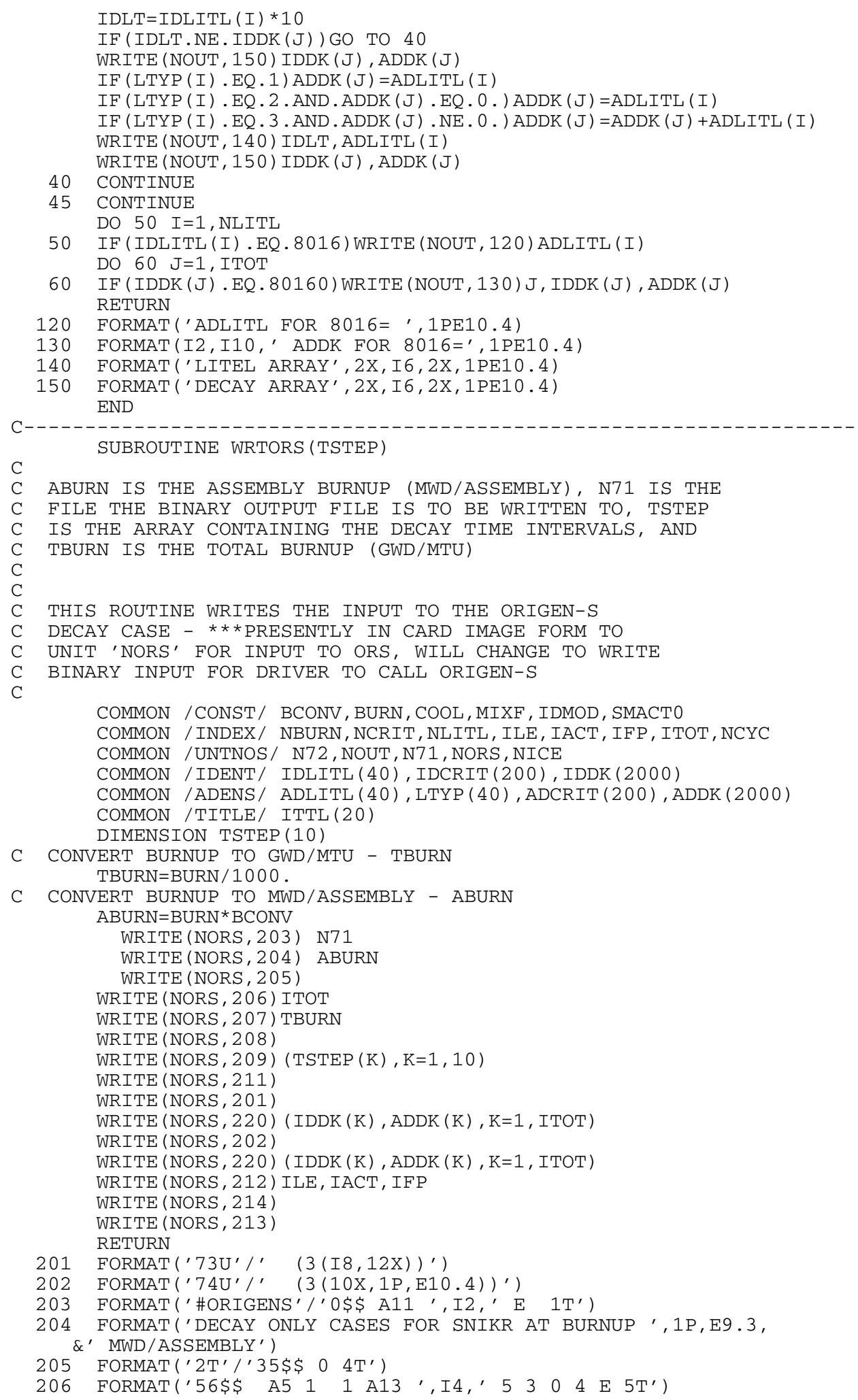




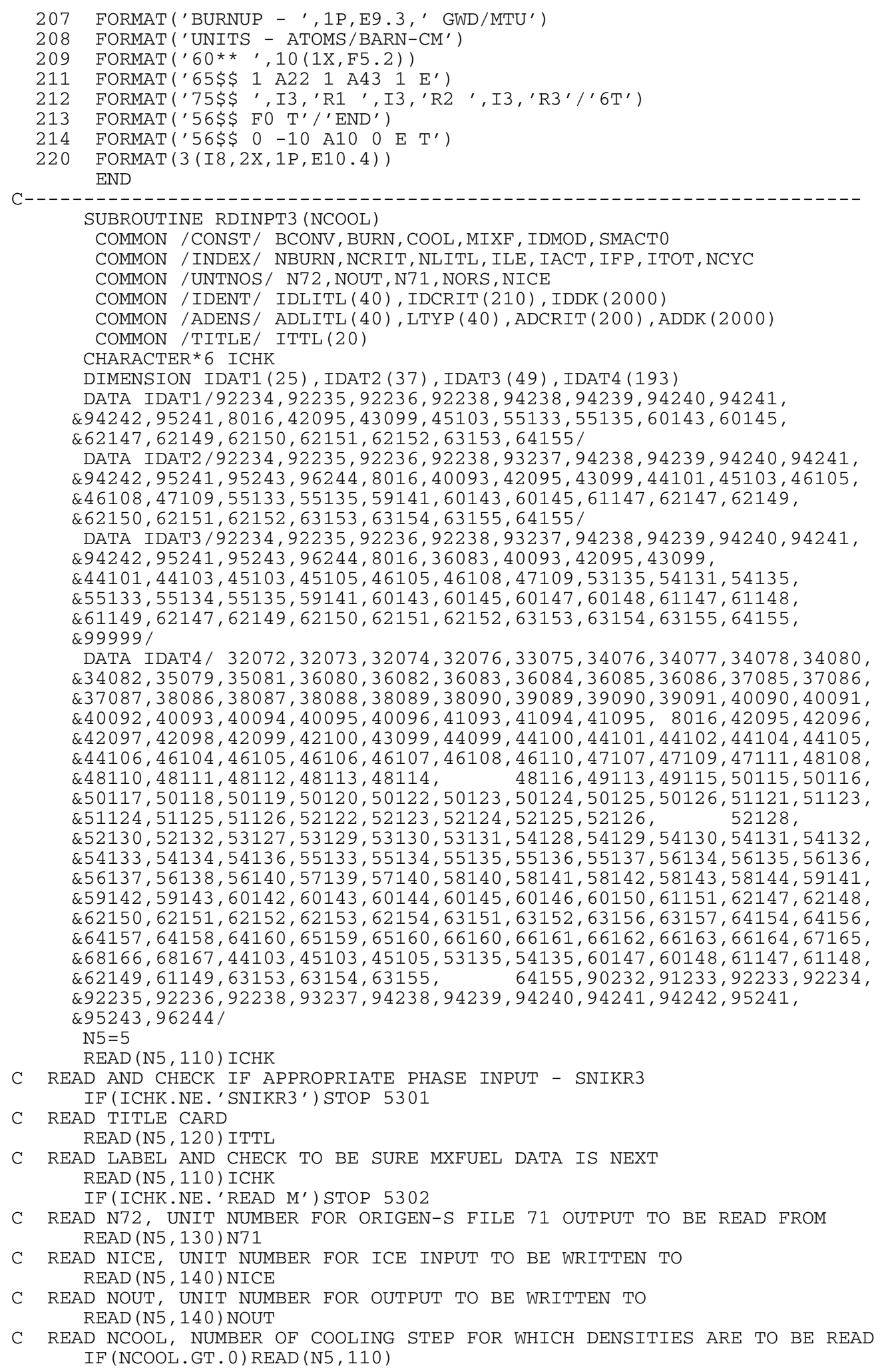


IF (NCOOL. EO. 0) READ (N5, 145) NCOOL

C

C

C

C

C READ FLAG NFIS TO DETERMINE WHICH FUEL NUCLIDES WILL BE USED IN KENO CALCULATIONS :

$=0$ USE TTC713 INTERSECTION WITH SID BIERMAN'S NUCS

$=-1$ USE TTC713

$=-2$ USE TTC713 U SID U VEPCO U CASMO

$=-3$ USE ALL 27BURNUPLIB NUCLIDES

$=N$ READ IN USER'S CHOICE OF NUCLIDES

READ (N5, 150) NFIS

IF (NFIS. EQ. 0 ) THEN

NCRIT $=25$

DO $10 \quad I=1, N C R I T$

$10 \operatorname{IDCRIT}(\mathrm{I})=\operatorname{IDAT} 1(\mathrm{I})$

GO TO 500

END IF

IF (NFIS . EQ . - 1) THEN

NCRIT $=37$

DO $20 I=1$, NCRIT

$20 \operatorname{IDCRIT}(I)=\operatorname{IDAT} 2(I)$

GO TO 500

END IF

IF (NFIS.EQ . - 2) THEN

NCRIT $=49$

DO $21 \quad I=1, N C R I T$

$21 \operatorname{IDCRIT}(\mathrm{I})=\operatorname{IDAT} 3(\mathrm{I})$

GO TO 500

END IF

IF (NFIS . EQ . - 3) THEN

NCRIT $=193$

DO $31 \mathrm{I}=1, \mathrm{NCRIT}$

$31 \operatorname{IDCRIT}(\mathrm{I})=\operatorname{IDAT} 4$ ( I )

GO TO 500

END IF

IF (NFIS . GT . 0) NCRIT=NFIS

500 CONTINUE

C READ MIXTURE NUMBER TO BE USED FOR FUEL OF THIS BURN IN KENO CALCULATIONS $\operatorname{READ}(\mathrm{N} 5,160) \mathrm{MIXF}$

C READ INTEGER MODIFIER FOR FUEL NUCLIDE ID'S FOR USE IN ICE RUN $\operatorname{READ}(\mathrm{N} 5,145)$ IDMOD

C READ AND CHECK THAT THIS IS END OF FUEL MIX DATA $\operatorname{READ}(\mathrm{N} 5,110) \mathrm{ICHK}$ IF ( ICHK. NE. 'END MX') STOP 5303

C IF FISPROD IS GREATER THAN ZERO READ IN ID'S OF ELEMENTS IN FUEL FOR

C CRITICALITY CALCULATIONS

IF (NFIS.LE.0) GO TO 1000

$\operatorname{READ}(\mathrm{N5}, 170)$ ( IDCRIT ( I ) , I=1, NCRIT)

1000 CONTINUE

WRITE INPUT TO NOUT

WRITE (NOUT, 120 ) ITTI

WRITE (NOUT, 130$)$ N71

WRITE (NOUT, 140 ) NICE

WRITE (NOUT, 140 ) NOUT

WRITE (NOUT, 145 ) NCOOL

WRITE (NOUT, 150 ) NFIS

WRITE (NOUT, 160 ) MIXF

WRITE (NOUT, 145 ) IDMOD

WRITE (NOUT, 170) ( IDCRIT ( I ) , I=1, NCRIT)

110 FORMAT (A6)

120 FORMAT (20A4)

130 FORMAT (4X, I2)

140 FORMAT (5X, I2)

145 FORMAT (6X, I2)

150 FORMAT (8X, I3)

160 FORMAT ( 5X, I4)

170 FORMAT (10 (1X, I5))

RETURN 


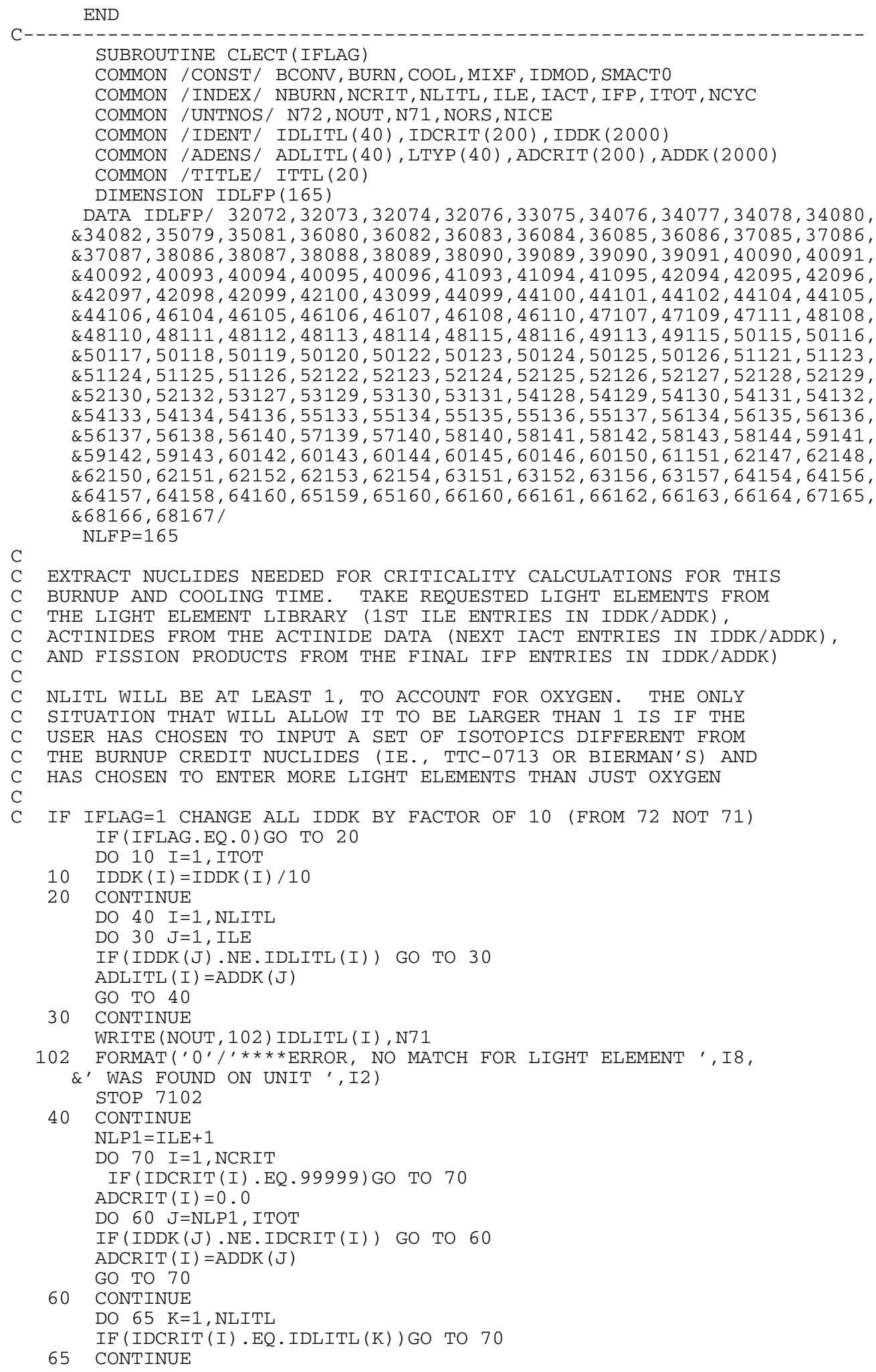




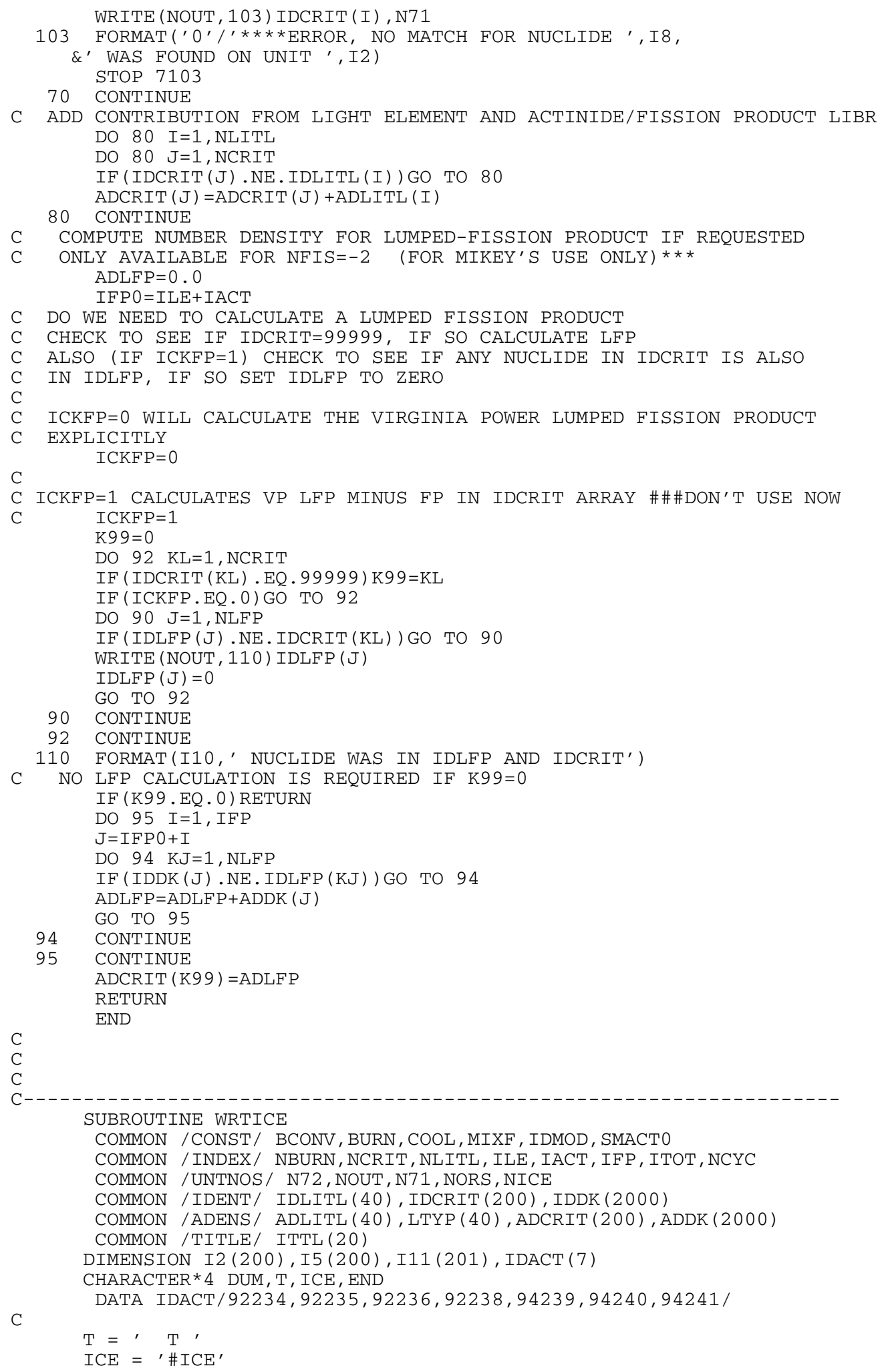




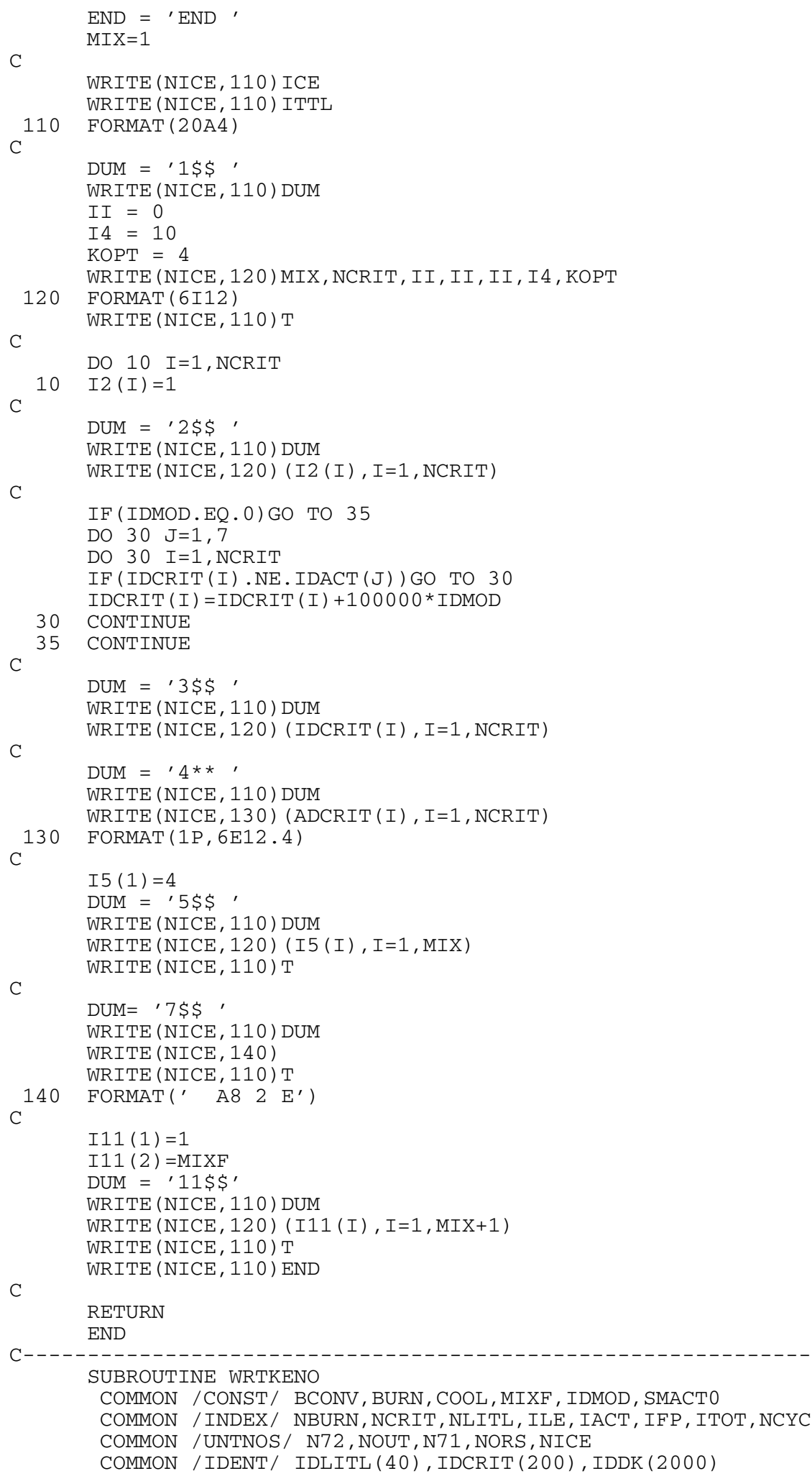




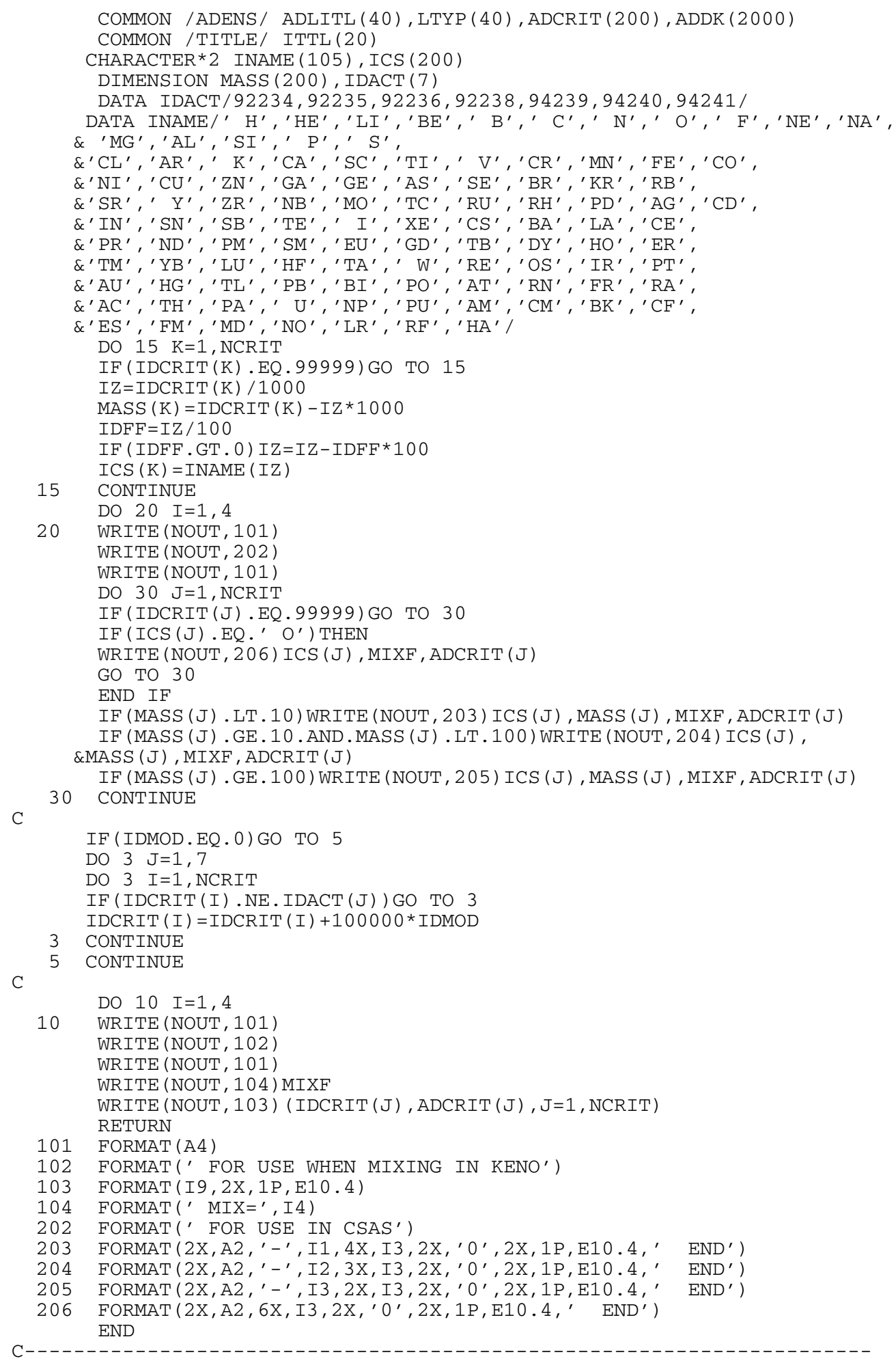




\section{SNIKR3 FORTRAN Listing}

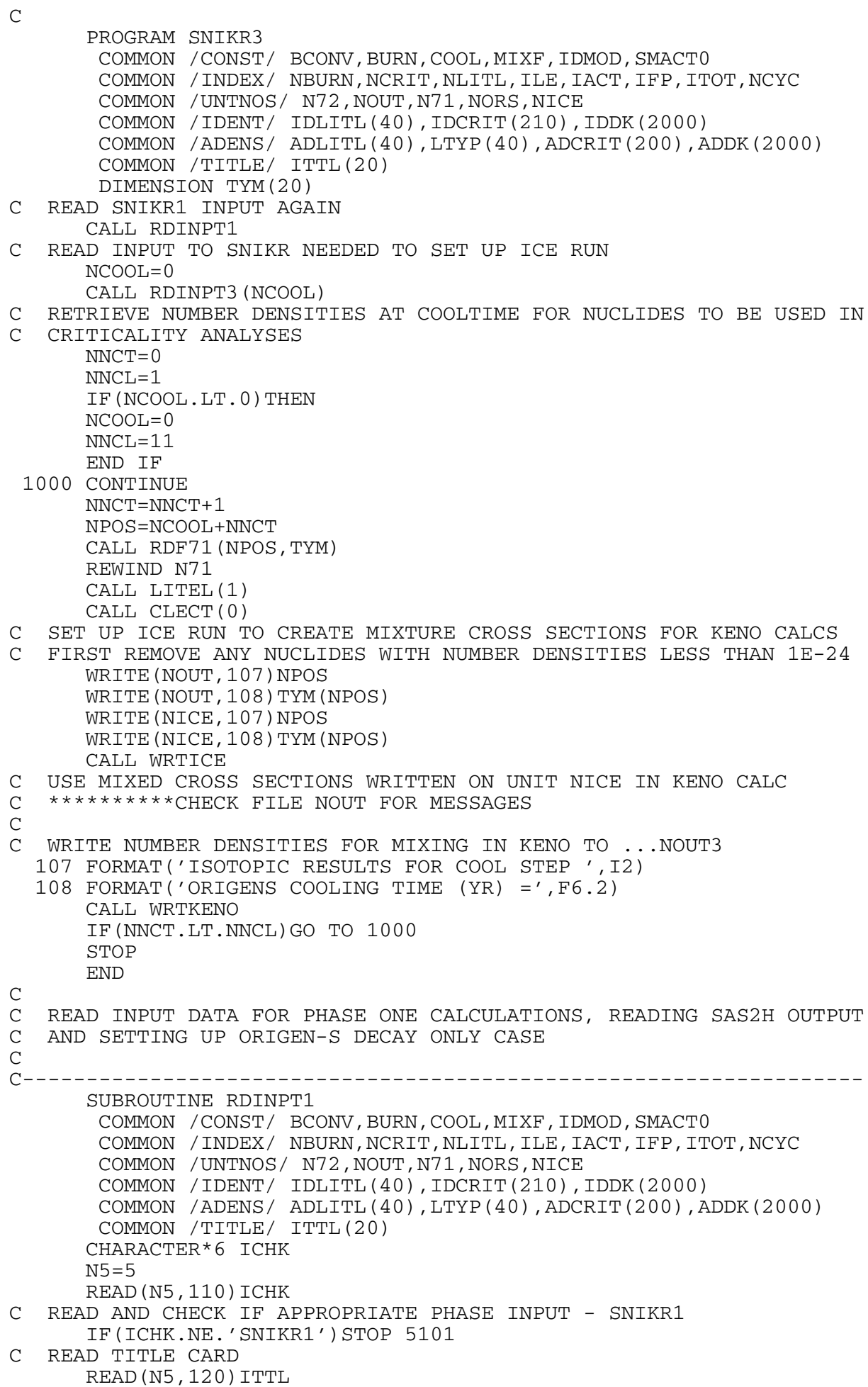


C READ LABEL AND CHECK TO BE SURE BURN DATA IS NEXT $\operatorname{READ}(\mathrm{N} 5,110)$ ICHK IF (ICHK.NE. 'READ B') STOP 5102

C READ N72, UNIT NUMBER FOR SAS2H FILE 72 OUTPUT TO BE READ FROM $\operatorname{READ}(\mathrm{N} 5,130) \mathrm{N} 72$

C READ NOUT, UNIT NUMBER FOR OUTPUT TO BE WRITTEN TO READ (N5, 140$)$ NOUT

C READ BURNUP IN MWD/MTU THAT NUMBER DENSITIES ARE TO BE RETRIEVED FROM N72 READ (N5, 150) BURN

C READ METAL (MTU/ASSEMBLY), BCONV IS CONVERSION FACTOR FOR BURNUPS

C READ FROM N72

C $\quad \operatorname{READ}(\mathrm{N} 5,160) \mathrm{BCONV}$

C $* * * *$ MODIFIED SNIKR, NOW READ FROM SAS2H OUTPUT

C READ NCYC, NUMBER OF BURN CYCLES USED TO PRODUCE SAS2H OUTPUT ON N72 READ (N5, 170) NCYC

C READ AND CHECK THAT THIS IS END OF BURNUP DATA $\operatorname{READ}(\mathrm{N} 5,110)$ ICHK IF (ICHK.NE. 'END BU') STOP 5103

C READ AND CHECK THAT DECAY DATA BEGINS WITH NEXT CARD $\operatorname{READ}(\mathrm{N} 5,110)$ ICHK

IF (ICHK.NE.' READ D') STOP 5104

C READ NORS, UNIT NUMBER FOR ORIGEN-S INPUT TO BE WRITTEN $\operatorname{READ}(\mathrm{N} 5,140)$ NORS

C READ N71, UNIT NUMBER FOR ORIGEN-S INPUT TO BE WRITTEN FOR PHASE 3 $\operatorname{READ}(\mathrm{N} 5,130) \mathrm{N} 71$

C READ COOLING TIME IN YEARS TO BE USED TO SET UP ORIGEN-S DECAY CASE READ (N5, 180 ) COOL

C READ THE NUMBER OF LIGHT ELEMENTS TO BE SPECIFIED IN THE DECAY CASE READ (N5, 190) NLITL

C READ AND CHECK THAT THIS IS THE END OF DECAY DATA $\operatorname{READ}(\mathrm{N} 5,110)$ ICHK IF (ICHK. NE. 'END DE') STOP 5105

C IF NLITL IS GREATER THAN ZERO READ IN ID'S OF LIGHT ELEMENTS IF (NLITL.EQ.0) GO TO 1000 $\operatorname{READ}(N 5,195$ ) (IDLITL ( I ), ADLITL (I) , LTYP (I) , I=1, NLITL)

1000 CONTINUE

$\mathrm{C}$

WRITE INPUT TO NOUT

C WRITE (NOUT, 120)ITTL

C WRITE (NOUT, 130)N72

C WRITE (NOUT, 140) NOUT

C WRITE (NOUT, 150) BURN

C WRITE (NOUT, 160) BCONV

C WRITE (NOUT, 170) NCYC

C WRITE (NOUT, 140) NORS

C WRITE (NOUT, 180) COOI

C WRITE (NOUT, 190) NLITL RETURN

110 FORMAT (A6)

120 FORMAT (20A4)

130 FORMAT ( $4 \mathrm{X}, \mathrm{I} 2)$

140 FORMAT ( $5 \mathrm{X}, \mathrm{I} 2)$

150 FORMAT (5X, F8.1)

160 FORMAT (6X, F6.4)

170 FORMAT (5X, I2)

180 FORMAT ( 8X, F6.2)

190 FORMAT ( 8X, I2)

195 FORMAT (1X, I5 , 1P , E10.4 , 0P , 2X, I1) END

C

C

SUBROUTINE RDINPT3 (NCOOL)

COMMON /CONST/ BCONV, BURN, COOL, MIXF, IDMOD, SMACTO

COMMON / INDEX/ NBURN, NCRIT, NLITL, ILE, IACT, IFP, ITOT, NCYC

COMMON /UNTNOS / N72, NOUT, N71, NORS , NICE 
COMMON /IDENT/ IDLITL (40), IDCRIT(210), IDDK (2000)

COMMON /ADENS/ ADLITL (40), LTYP (40), ADCRIT (200), ADDK (2000)

COMMON /TITLE/ ITTL (20)

CHARACTER * 6 ICHK

DIMENSION IDAT1 (25), IDAT2 (37), IDAT3 (49), IDAT4 (193)

DATA IDAT1/92234,92235,92236,92238,94238,94239,94240,94241, $\& 94242,95241,8016,42095,43099,45103,55133,55135,60143,60145$, $\& 62147,62149,62150,62151,62152,63153,64155 /$

DATA IDAT2/92234,92235,92236,92238,93237,94238,94239,94240,94241, $\& 94242,95241,95243,96244,8016,40093,42095,43099,44101,45103,46105$, $\& 46108,47109,55133,55135,59141,60143,60145,61147,62147,62149$, $\& 62150,62151,62152,63153,63154,63155,64155 /$

DATA IDAT3/92234,92235,92236,92238,93237,94238,94239,94240,94241, $\& 94242,95241,95243,96244,8016,36083,40093,42095,43099$,

$\& 44101,44103,45103,45105,46105,46108,47109,53135,54131,54135$, $\& 55133,55134,55135,59141,60143,60145,60147,60148,61147,61148$ \&61149,62147,62149,62150,62151, 62152,63153,63154,63155, 64155， \&99999/

DATA IDAT4/ 32072,32073,32074,32076,33075,34076,34077,34078,34080, $\& 34082,35079,35081,36080,36082,36083,36084,36085,36086,37085,37086$, $\& 37087,38086,38087,38088,38089,38090,39089,39090,39091,40090,40091$, $\& 40092,40093,40094,40095,40096,41093,41094,41095,8016,42095,42096$ \&42097,42098,42099,42100,43099,44099,44100,44101,44102,44104,44105, $\& 44106,46104,46105,46106,46107,46108,46110,47107,47109,47111,48108$, $\& 48110,48111,48112,48113,48114, \quad 48116,49113,49115,50115,50116$, $\& 50117,50118,50119,50120,50122,50123,50124,50125,50126,51121,51123$, $\& 51124,51125,51126,52122,52123,52124,52125,52126,52128$ $\& 52130,52132,53127,53129,53130,53131,54128,54129,54130,54131,54132$, $\& 54133,54134,54136,55133,55134,55135,55136,55137,56134,56135,56136$, $\& 56137,56138,56140,57139,57140,58140,58141,58142,58143,58144,59141$, $\& 59142,59143,60142,60143,60144,60145,60146,60150,61151,62147,62148$, $\& 62150,62151,62152,62153,62154,63151,63152,63156,63157,64154,64156$, $\& 64157,64158,64160,65159,65160,66160,66161,66162,66163,66164,67165$ $\& 68166,68167,44103,45103,45105,53135,54135,60147,60148,61147,61148$, \&62149,61149,63153,63154,63155, 64155,90232,91233,92233,92234, $\& 92235,92236,92238,93237,94238,94239,94240,94241,94242,95241$, $\& 95243,96244 /$

$\mathrm{N} 5=5$

$\operatorname{READ}(\mathrm{N} 5,110)$ ICHK

C READ AND CHECK IF APPROPRIATE PHASE INPUT - SNIKR3 IF (ICHK.NE. 'SNIKR3') STOP 5301

C READ TITLE CARD READ (N5, 120) ITTL

C READ LABEL AND CHECK TO BE SURE MXFUEL DATA IS NEXT READ (N5, 110) ICHK IF (ICHK.NE. 'READ M') STOP 5302

C READ N72, UNIT NUMBER FOR ORIGEN-S FILE 71 OUTPUT TO BE READ FROM READ (N5, 130) N71

C READ NICE, UNIT NUMBER FOR ICE INPUT TO BE WRITTEN TO READ (N5, 140) NICE

C READ NOUT, UNIT NUMBER FOR OUTPUT TO BE WRITTEN TO READ (N5, 140) NOUT

C READ NCOOL, NUMBER OF COOLING STEP FOR WHICH DENSITIES ARE TO BE READ IF (NCOOL.GT . 0) READ (N5,110)

IF (NCOOL.EQ. 0) READ (N5,145) NCOOL

C READ FLAG NFIS TO DETERMINE WHICH FUEL NUCLIDES WILL BE USED IN

C KENO CALCULATIONS:

C $\quad=0$ USE TTC713 INTERSECTION WITH SID BIERMAN'S NUCS

C $\quad=-1$ USE TTC713

$=-2$ USE TTC713 U SID U VEPCO U CASMO

$=-3$ USE ALL 27BURNUPLIB NUCLIDES

$=\mathrm{N}$ READ IN USER'S CHOICE OF NUCLIDES

READ (N5, 150) NFIS

IF (NFIS.EQ.0) THEN

NCRIT $=25$

DO $10 \quad I=1$, NCRIT

$10 \operatorname{IDCRIT}(\mathrm{I})=\operatorname{IDAT} 1$ ( I )

GO TO 500 


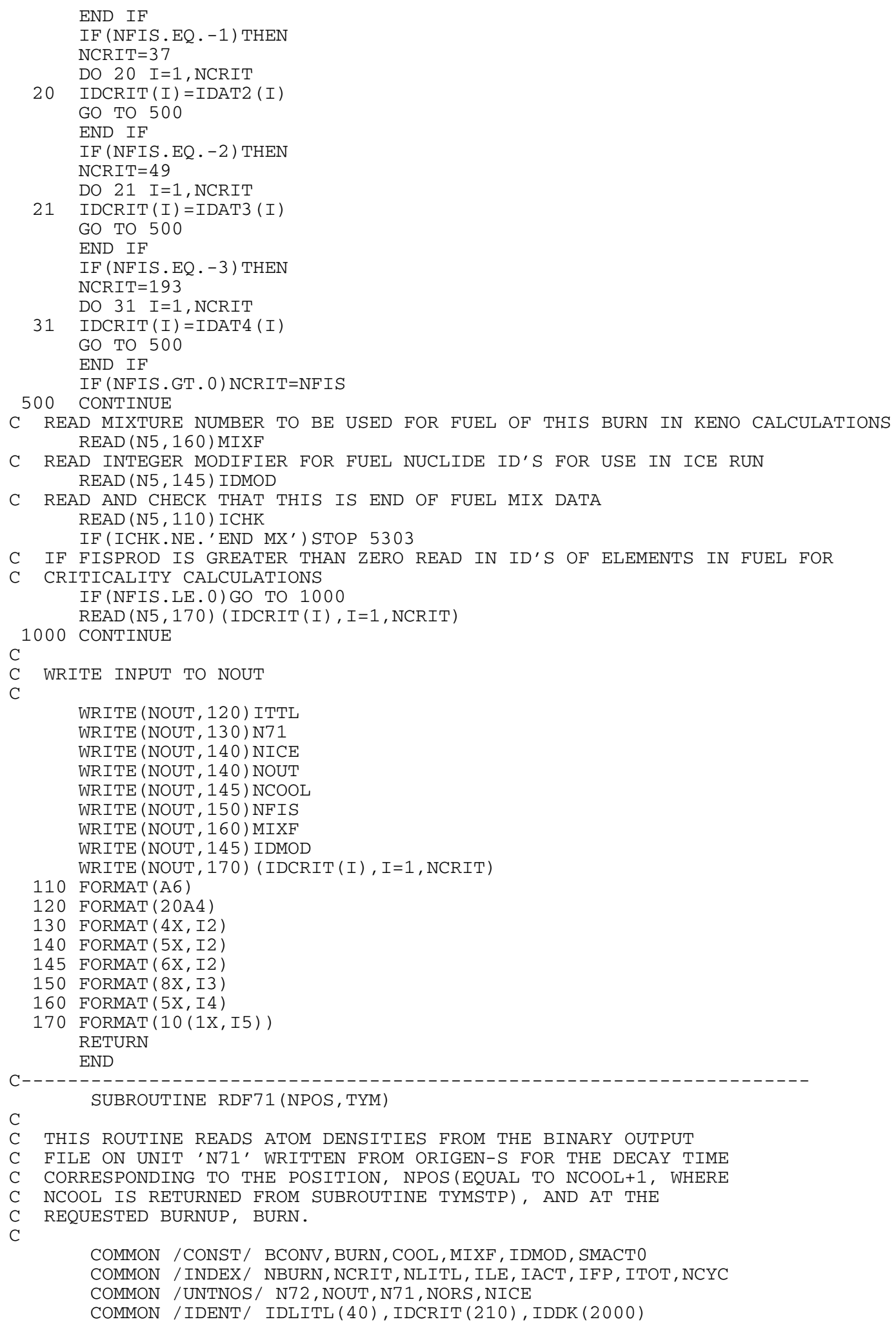


COMMON /ADENS/ ADLITL (40), LTYP (40), ADCRIT (200), ADDK (2000)

COMMON /TITLE/ ITTL (20)

DIMENSION TYM $(20)$

C

C

$\mathrm{C}$

C

C

IDDK AND ADDK ARE ARRAYS CONTAINING THE ID'S AND NUMBER DENSITIES FOR ALL NUCLIDES USED IN THE ORIGEN-S DECAY

CASE. IN THIS ROUTINE THEY ARE USED TO RETRIEVE DATA FROM UNIT N71

FORE IT IS CONDENSED INTO THE ADCRIT ARRAY WHICH WILL CONTAIN NUMBER

TITIE CORRESPONDING TO THE ID'S GIVEN IN IDCRIT. IDCRIT CONTAINS

DENSITIES STORED IN ADCRIT ARE BURNUP DEPENDENT.

FILES NEEDED IN THIS SUBROUTINE SHOULD BE OPENED BY THE MAIN PROGRAM

10 READ (N71, END=100) ITOT, ILE, IACT, IFP, ND1, ND2, NSTEP, $\& \mathrm{~N} 1, \mathrm{~N} 2, \mathrm{~N} 3, \mathrm{~N} 4, \mathrm{~N} 5, \mathrm{~N} 6, \mathrm{~N} 7, \mathrm{~N} 8, \mathrm{~N} 9, \mathrm{~N} 10, \mathrm{~N} 11, \mathrm{~N} 12, \mathrm{~N} 13, \mathrm{~N} 14, \mathrm{~N} 15$,

\&N16 , N17 , N18, N19, N2 0 , N21, N22 , N2 3 , R1 , R2 , R3 , R4 , TYM (NPOS)

WRITE (NOUT, 102 ) ITOT, ILE, IACT, IFP , NSTEP , TYM (NPOS)

IF (NSTEP.EQ.NPOS) THEN

$\operatorname{READ}(\mathrm{N} 71, \mathrm{END}=100) \quad(\mathrm{IDDK}(\mathrm{I}), \mathrm{I}=1, \mathrm{ITOT}),(\mathrm{ADDK}(\mathrm{I}), \mathrm{I}=1, \mathrm{ITOT})$

$15 \operatorname{IDDK}(\mathrm{I})=\operatorname{IDDK}(\mathrm{I}) / 10$

$I A 1=I L E+1$

IA2 $=$ ILE+IACT

WRITE (NOUT, 103 ) ( IDDK ( I ), ADDK ( I ) , I=IA1, IA2)

GO TO 20

ENDIF

READ (N71, END=100) IDUMY

GO TO 10

100 WRITE (NOUT, 101) N71

101 FORMAT ('0', '****ERROR READING UNIT ', I2)

STOP 7101

20 CONTINUE

102 FORMAT ( $5(1 \mathrm{X}, \mathrm{I} 4), \mathrm{F} 6.2)$

103 FORMAT ( 4 (I8, 2X, 1P, E10.4))

RETURN

END

C---- - - - - - - - - - - - - - - - - - - - - - - - - - - - - - - - - - - - - - - - - - - - - - -

C

C THIS SUBROUTINE CHECKS TO SEE IF ANY

C LIGHT ELEMENTS ARE REQUESTED BY THE

C USER, IF OXYGEN IS NOT EXPLICITLY

C REQUESTED IT IS ADDED.

COMMON /CONST/ BCONV, BURN, COOL, MIXF, IDMOD, SMACTO

COMMON / INDEX/ NBURN, NCRIT, NLITL, ILE, IACT, IFP, ITOT, NCYC

COMMON / UNTNOS / N72, NOUT, N71, NORS, NICE

COMMON /IDENT/ IDLITL (40), IDCRIT (210), IDDK (2000)

COMMON /ADENS/ ADLITL (40), LTYP(40), ADCRIT (200), ADDK (2000)

C COMMON /TITLE/ ITTL(20)

IF (NLITL.NE. 0) GO TO 10

NLITL $=1$

$\operatorname{IDLITL~}(1)=8016$

$\operatorname{LTYP}(1)=1$

GO TO 30

10 CONTINUE

DO 20 I=1, NLITL

IF (IDLITL (I).EQ.8016) GO TO 35

20 CONTINUE

NLITL $=$ NLITL +1

IDLITL $($ NLITL $)=8016$

LTYP (NLITL) $=1$

30 CONTINUE

IF (IFLAG.EQ.1) GO TO 45

ADLITL (NLITL) $=2.0$ * SMACTO

WRITE (NOUT, 110 ) ADLITL (NLITL) 


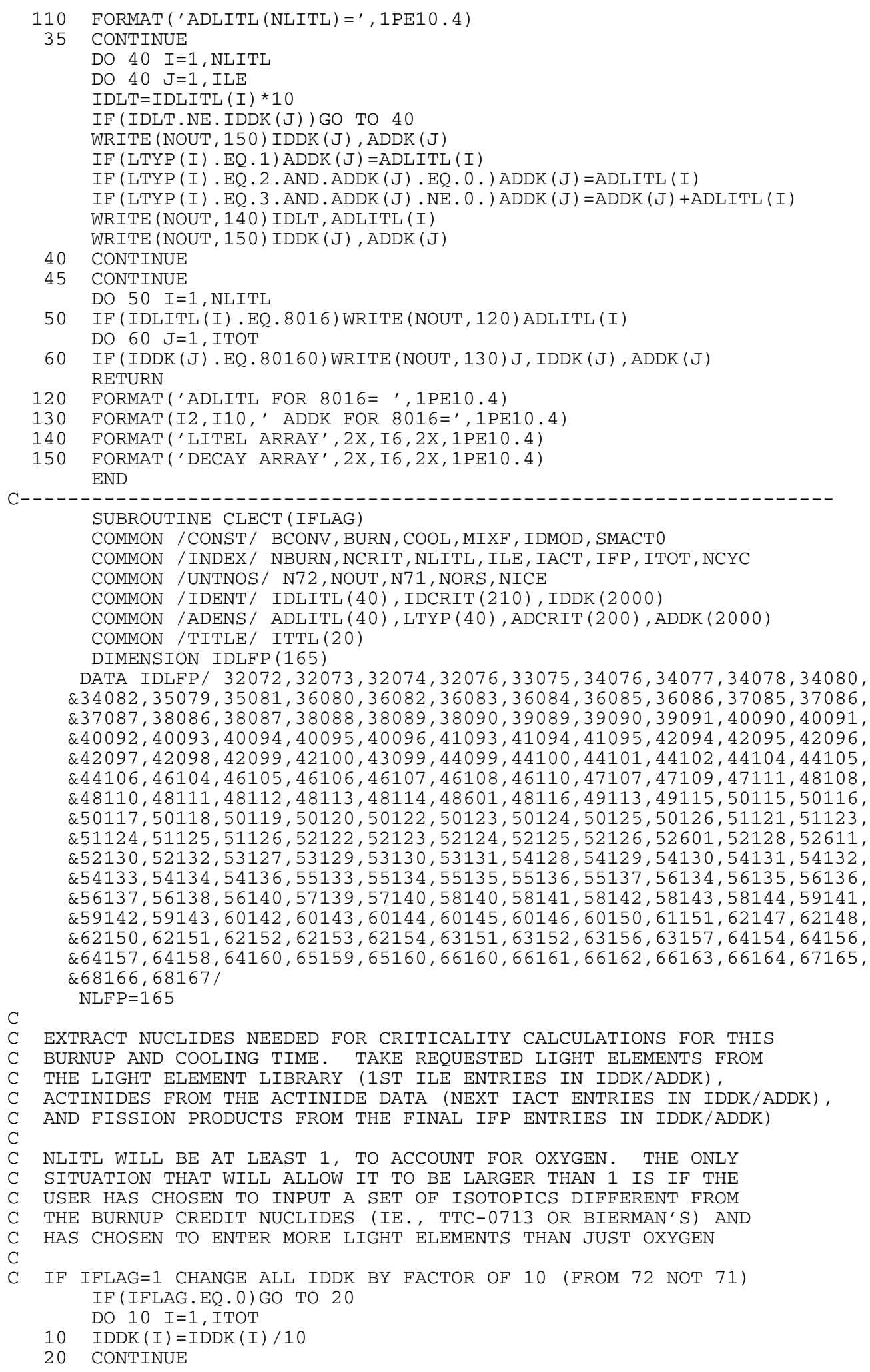




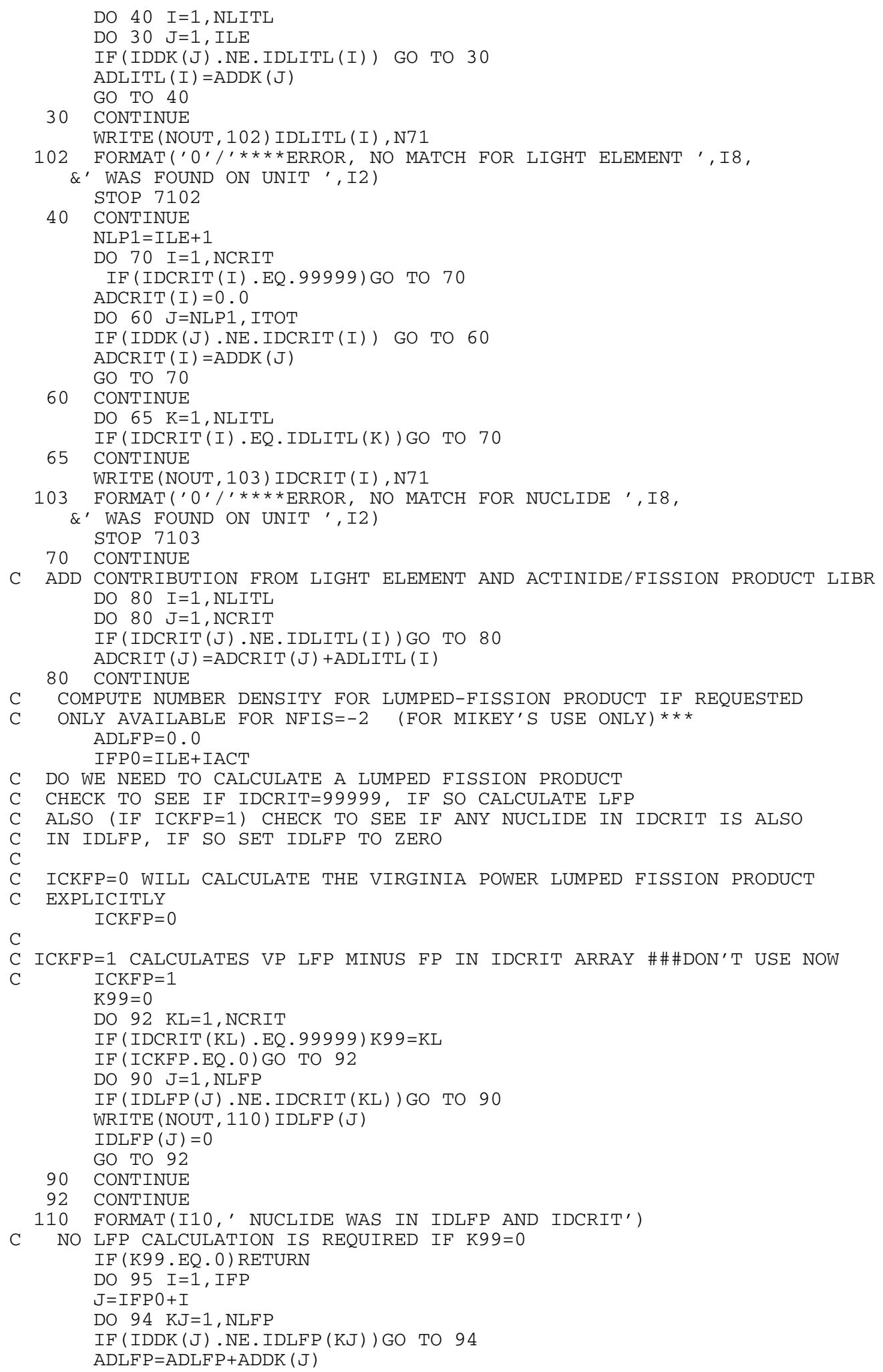




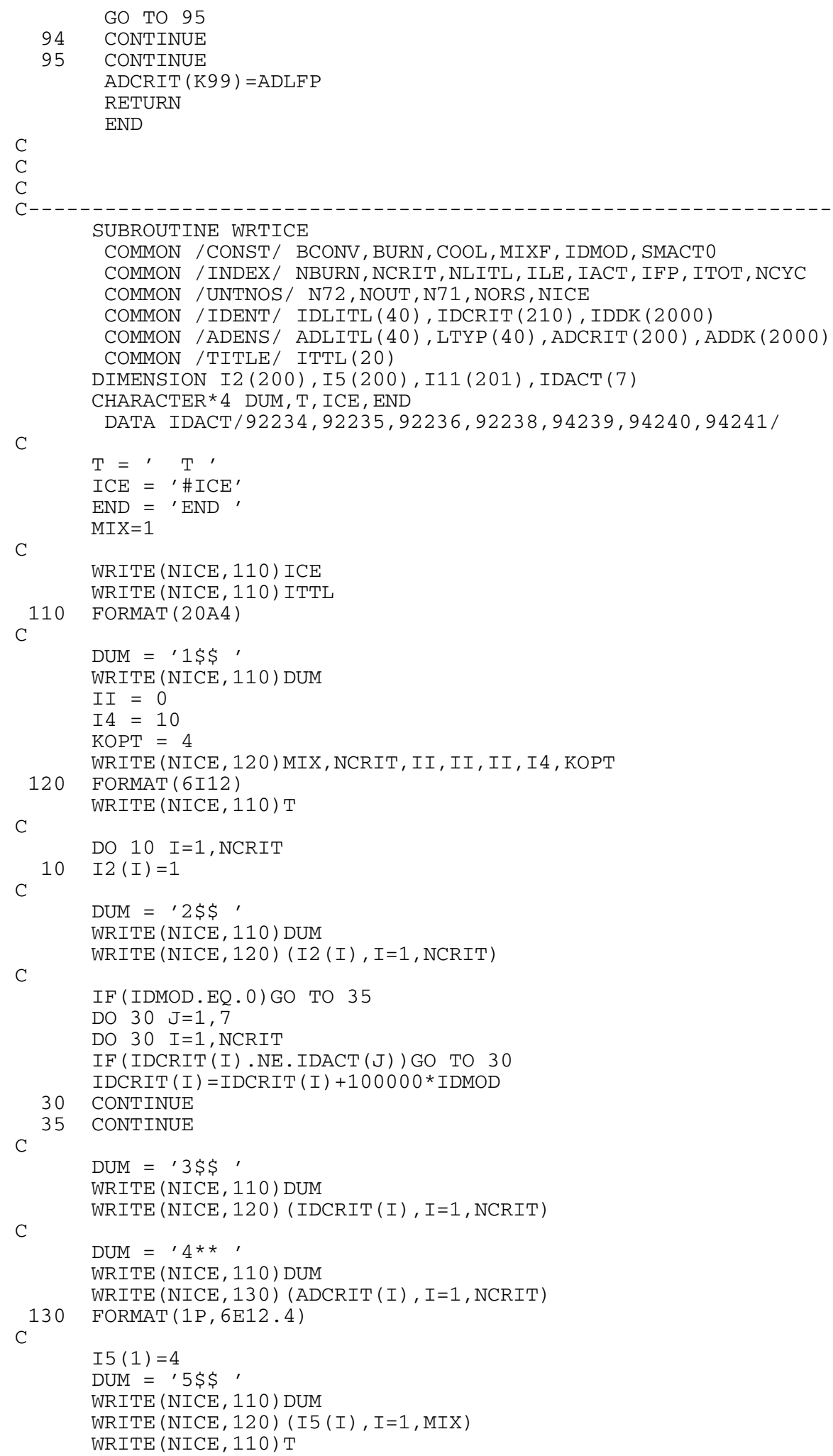


C

$\mathrm{DUM}=, 7 \$ \$$,

WRITE (NICE, 110) DUM

WRITE (NICE, 140)

WRITE (NICE, 110) T

C

A8 $2 \mathrm{E}^{\prime}$ )

$\operatorname{II1}(1)=1$

$\operatorname{I11}(2)=\mathrm{MIXF}$

$\mathrm{DUM}=, 11 \$ \$$

WRITE (NICE, 110) DUM

WRITE (NICE, 120) (I11 (I) , I=1, MIX+1)

WRITE (NICE, 110) T

C

WRITE (NICE, 110) END

RETURN

END

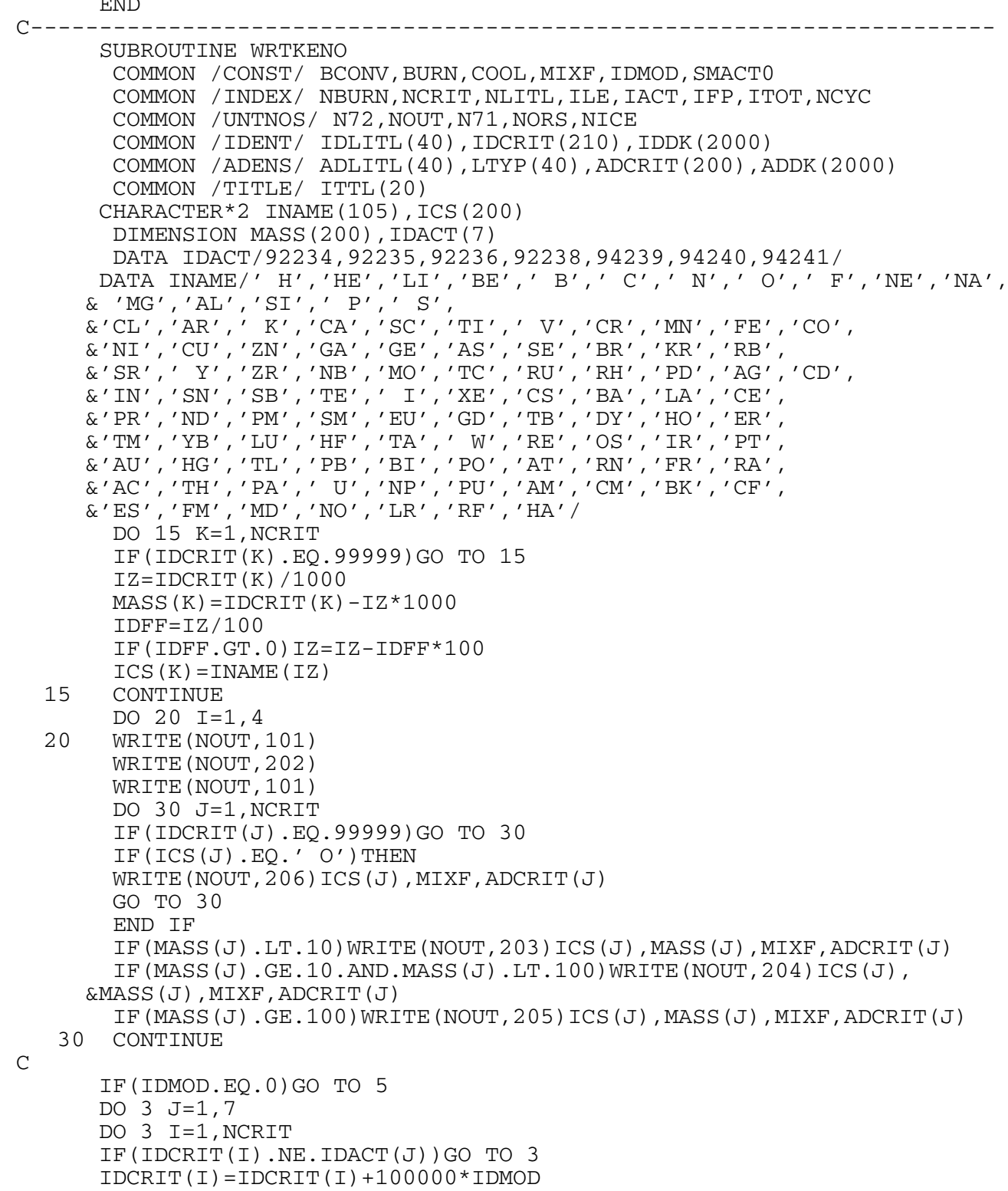




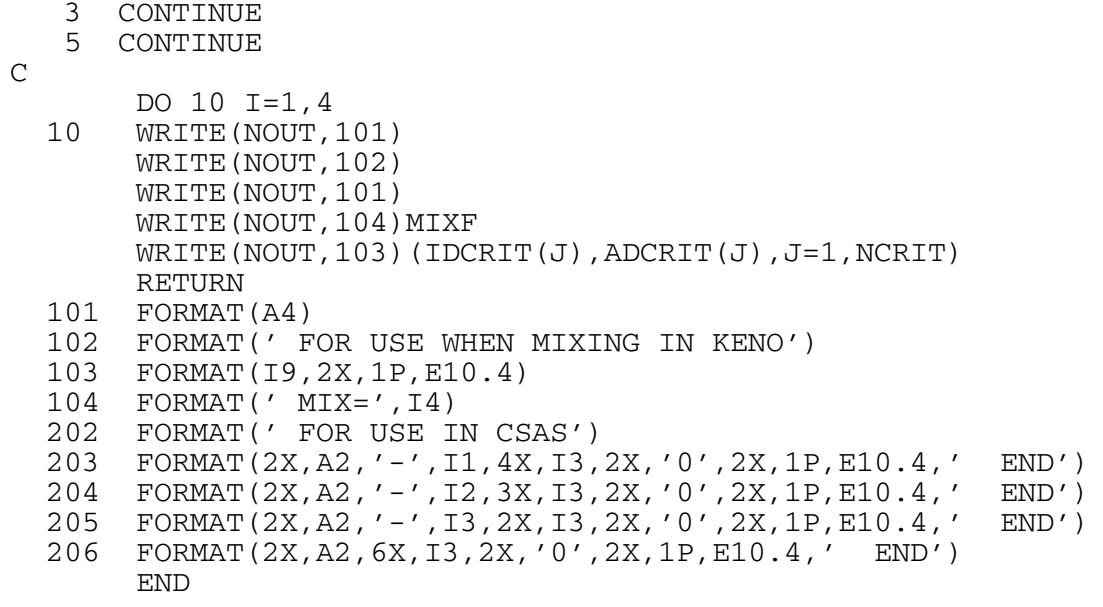




\section{Sample SNIKR Output}

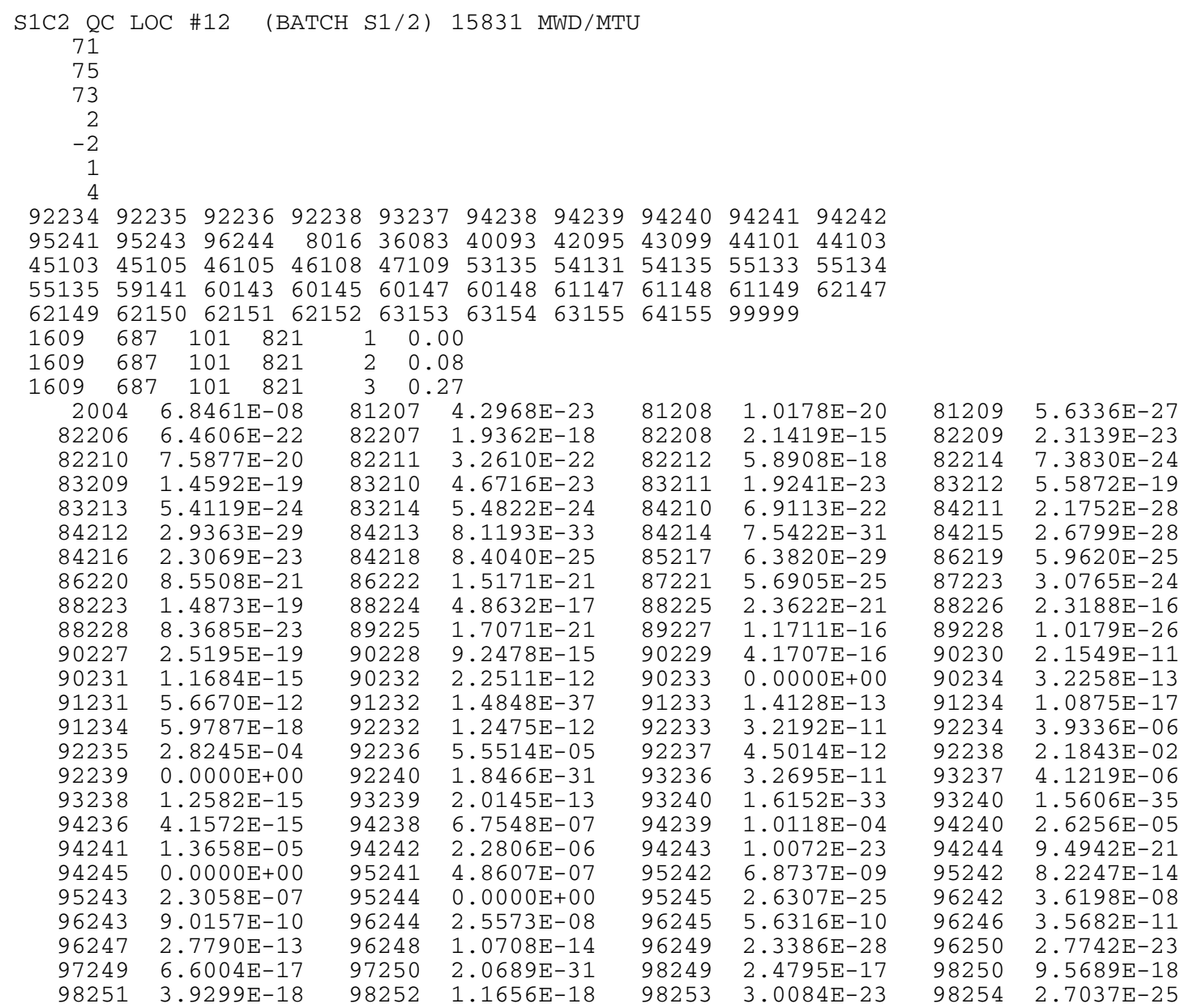

ADLITL FOR $8016=0.0000 \mathrm{E}+00$

ISOTOPIC RESULTS FOR COOL STEP 3

ORIGENS COOLING TIME $(\mathrm{YR})=0.27$

FOR USE IN CSAS

$\begin{array}{ccccc}\mathrm{U}-234 & 1 & 0 & 3.9336 \mathrm{E}-06 & \text { END } \\ \mathrm{U}-235 & 1 & 0 & 2.8245 \mathrm{E}-04 & \text { END } \\ \mathrm{U}-236 & 1 & 0 & 5.5514 \mathrm{E}-05 & \text { END } \\ \mathrm{U}-238 & 1 & 0 & 2.1843 \mathrm{E}-02 & \text { END } \\ \mathrm{NP}-237 & 1 & 0 & 4.1219 \mathrm{E}-06 & \mathrm{END} \\ \mathrm{PU}-238 & 1 & 0 & 6.7548 \mathrm{E}-07 & \mathrm{END} \\ \mathrm{PU}-239 & 1 & 0 & 1.0118 \mathrm{E}-04 & \mathrm{END} \\ \mathrm{PU}-240 & 1 & 0 & 2.6256 \mathrm{E}-05 & \mathrm{END} \\ \mathrm{PU}-241 & 1 & 0 & 1.3658 \mathrm{E}-05 & \mathrm{END} \\ \mathrm{PU}-242 & 1 & 0 & 2.2806 \mathrm{E}-06 & \mathrm{END} \\ \mathrm{AM}-241 & 1 & 0 & 4.8607 \mathrm{E}-07 & \mathrm{END} \\ \mathrm{AM}-243 & 1 & 0 & 2.3058 \mathrm{E}-07 & \text { END } \\ \mathrm{CM}-244 & 1 & 0 & 2.5573 \mathrm{E}-08 & \text { END } \\ \mathrm{O} & 1 & 0 & 4.5425 \mathrm{E}-02 & \mathrm{END} \\ \mathrm{KR}-83 & 1 & 0 & 1.5402 \mathrm{E}-06 & \text { END }\end{array}$




\begin{tabular}{|c|c|c|c|c|}
\hline $\mathrm{ZR}-93$ & 1 & 0 & $2.1149 \mathrm{E}-05$ & END \\
\hline $\mathrm{MO}-95$ & 1 & 0 & $2.0312 \mathrm{E}-05$ & END \\
\hline$\Gamma \mathrm{C}-99$ & 1 & 0 & $2.2028 E-05$ & END \\
\hline RU-101 & 1 & 0 & $1.9971 \mathrm{E}-05$ & EN \\
\hline RU-103 & 1 & 0 & $2.6063 \mathrm{E}-07$ & ENI \\
\hline $2 \mathrm{H}-103$ & 1 & 0 & 1. $3102 \mathrm{E}-05$ & EN \\
\hline RH-105 & 1 & 0 & $2.8445 E-28$ & $\mathrm{EN}$ \\
\hline PD-105 & 1 & 0 & $8.3881 E-06$ & EN \\
\hline PD-108 & 1 & 0 & $2.5766 \mathrm{E}-06$ & EN \\
\hline AG-109 & 1 & 0 & $1.7831 \mathrm{E}-06$ & EN \\
\hline$I-135$ & 1 & 0 & $0.0000 \mathrm{E}+00$ & EN \\
\hline $\mathrm{XE}-131$ & 1 & 0 & $1.0146 \mathrm{E}-05$ & $\mathrm{EN}$ \\
\hline $\mathrm{XE}-135$ & 1 & 0 & $0.0000 \mathrm{E}+00$ & EN \\
\hline$S-133$ & 1 & 0 & $2.4025 E-05$ & EN \\
\hline$C S-134$ & 1 & 0 & $1.1673 \mathrm{E}-06$ & ENI \\
\hline$C S-135$ & 1 & 0 & $8.3186 \mathrm{E}-06$ & EN \\
\hline$P R-141$ & 1 & 0 & $2.0945 E-05$ & EN \\
\hline ND-143 & 1 & 0 & $1.7631 \mathrm{E}-05$ & EN \\
\hline$N D-145$ & 1 & 0 & 1. $3196 \mathrm{E}-05$ & EN \\
\hline ND-147 & 1 & 0 & $3.8702 \mathrm{E}-10$ & EN \\
\hline ND-148 & 1 & 0 & $6.4108 \mathrm{E}-06$ & EN \\
\hline PM-147 & 1 & 0 & $4.4808 E-06$ & EN \\
\hline $\mathrm{PM}-148$ & 1 & 0 & 4. $2081 E-11$ & ENI \\
\hline PM-149 & 1 & 0 & 1. $0986 \mathrm{E}-21$ & EN \\
\hline SM-147 & 1 & 0 & $1.5822 \mathrm{E}-06$ & EN \\
\hline$S M-149$ & 1 & 0 & $9.9207 E-08$ & EN \\
\hline SM-150 & 1 & 0 & $5.1276 \mathrm{E}-06$ & EN \\
\hline SM-151 & 1 & 0 & $3.5356 \mathrm{E}-07$ & $\mathrm{EN}$ \\
\hline SM-152 & 1 & 0 & $2.4213 \mathrm{E}-06$ & EN \\
\hline EU-153 & 1 & 0 & $1.5000 \mathrm{E}-06$ & EN \\
\hline EU-154 & 1 & 0 & $3.4167 E-07$ & EN \\
\hline EU-155 & 1 & 0 & 1. $4913 E-07$ & EN \\
\hline GD-155 & 1 & 0 & $7.0200 \mathrm{E}-09$ & EN \\
\hline
\end{tabular}

FOR USE WHEN MIXING IN KENO

$\begin{array}{rr}\mathrm{MIX}= & \\ 492234 & 3.9336 \mathrm{E}-06 \\ 492235 & 2.8245 \mathrm{E}-04 \\ 492236 & 5.5514 \mathrm{E}-05 \\ 492238 & 2.1843 \mathrm{E}-02 \\ 93237 & 4.1219 \mathrm{E}-06 \\ 94238 & 6.7548 \mathrm{E}-07 \\ 494239 & 1.0118 \mathrm{E}-04 \\ 494240 & 2.6256 \mathrm{E}-05 \\ 494241 & 1.3658 \mathrm{E}-05 \\ 94242 & 2.2806 \mathrm{E}-06 \\ 95241 & 4.8607 \mathrm{E}-07 \\ 95243 & 2.3058 \mathrm{E}-07 \\ 96244 & 2.5573 \mathrm{E}-08 \\ 8016 & 4.5425 \mathrm{E}-02 \\ 36083 & 1.5402 \mathrm{E}-06 \\ 40093 & 2.1149 \mathrm{E}-05 \\ 42095 & 2.0312 \mathrm{E}-05 \\ 43099 & 2.2028 \mathrm{E}-05 \\ 44101 & 1.9971 \mathrm{E}-05 \\ 44103 & 2.6063 \mathrm{E}-07 \\ 45103 & 1.3102 \mathrm{E}-05 \\ 45105 & 2.8445 \mathrm{E}-28 \\ 46105 & 8.3881 \mathrm{E}-06 \\ 46108 & 2.5766 \mathrm{E}-06 \\ 47109 & 1.7831 \mathrm{E}-06 \\ 53135 & 0.0000 \mathrm{E}+00 \\ 54131 & 1.0146 \mathrm{E}-05 \\ 54135 & 0.0000 \mathrm{E}+00\end{array}$




$\begin{array}{ll}55133 & 2.4025 \mathrm{E}-05 \\ 55134 & 1.1673 \mathrm{E}-06 \\ 55135 & 8.3186 \mathrm{E}-06 \\ 59141 & 2.0945 \mathrm{E}-05 \\ 60143 & 1.7631 \mathrm{E}-05 \\ 60145 & 1.3196 \mathrm{E}-05 \\ 60147 & 3.8702 \mathrm{E}-10 \\ 60148 & 6.4108 \mathrm{E}-06 \\ 61147 & 4.4808 \mathrm{E}-06 \\ 61148 & 4.2081 \mathrm{E}-11 \\ 61149 & 1.0986 \mathrm{E}-21 \\ 62147 & 1.5822 \mathrm{E}-06 \\ 62149 & 9.9207 \mathrm{E}-08 \\ 62150 & 5.1276 \mathrm{E}-06 \\ 62151 & 3.5356 \mathrm{E}-07 \\ 62152 & 2.4213 \mathrm{E}-06 \\ 63153 & 1.5000 \mathrm{E}-06 \\ 63154 & 3.4167 \mathrm{E}-07 \\ 63155 & 1.4913 \mathrm{E}-07 \\ 64155 & 7.0200 \mathrm{E}-09 \\ 99999 & 7.3267 \mathrm{E}-04\end{array}$




\section{APPENDIX D}

\section{KENO V.a BOC MODEL SETUP INPUT EXAMPLES}

This appendix gives examples of the input for the different calculational steps for setting up the Surry Unit 1 Cycle 2 KENO V.a model for BOC (HZP). 
Table D.1. SNIKR/ORIGEN-S input for fuel assembly isotopics

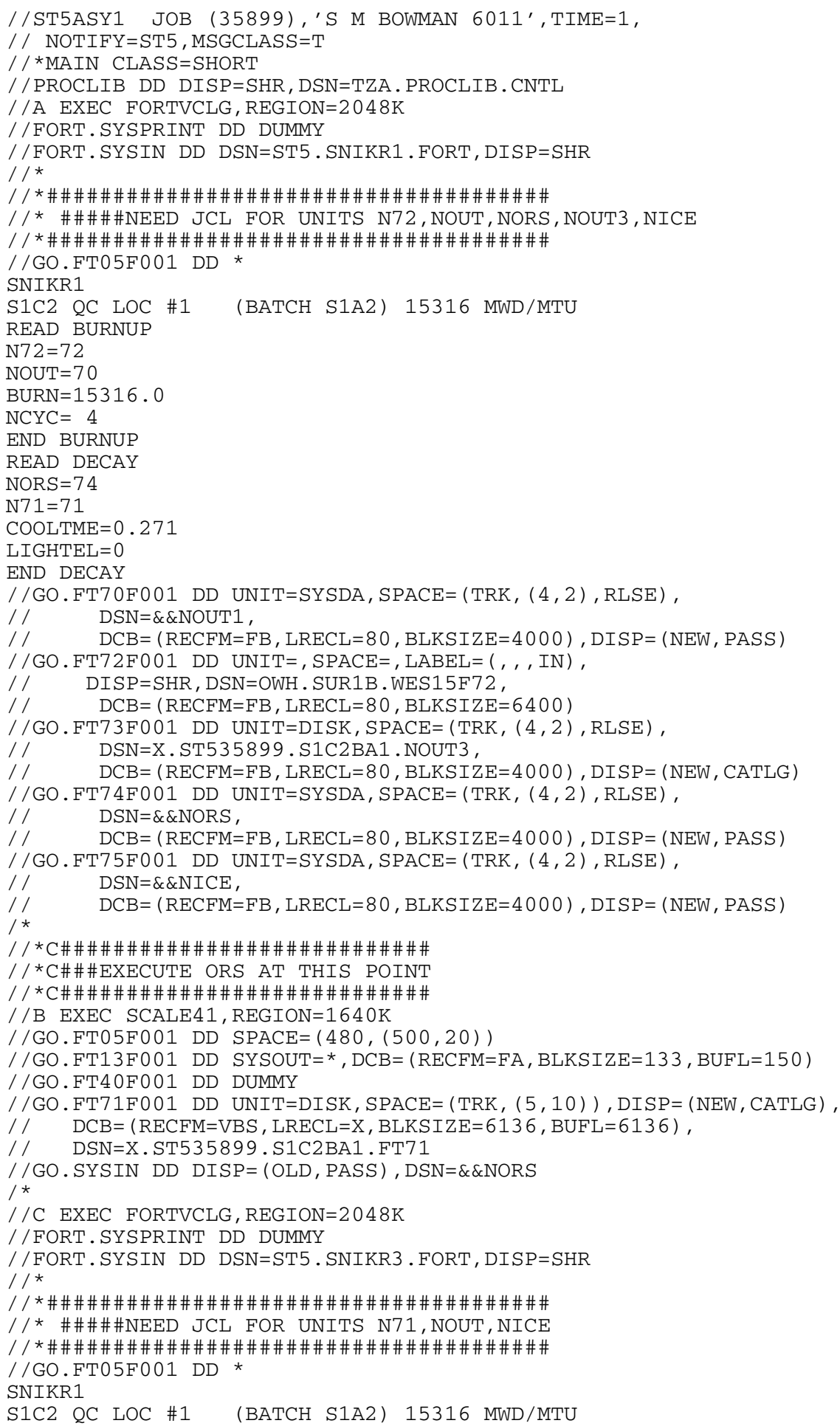


Table D.1. (continued)

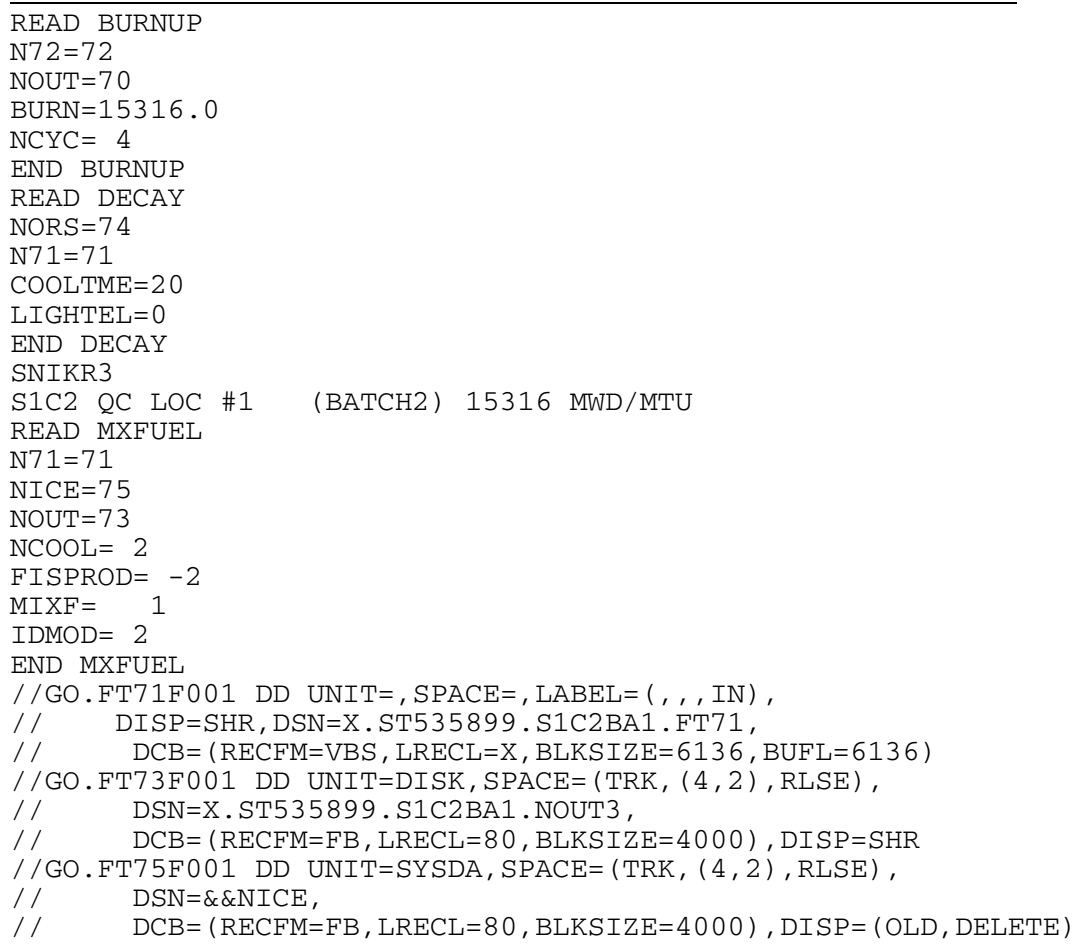




\section{Table D.2. SNIKR/ORIGEN-S input for cross-section} set average isotopics

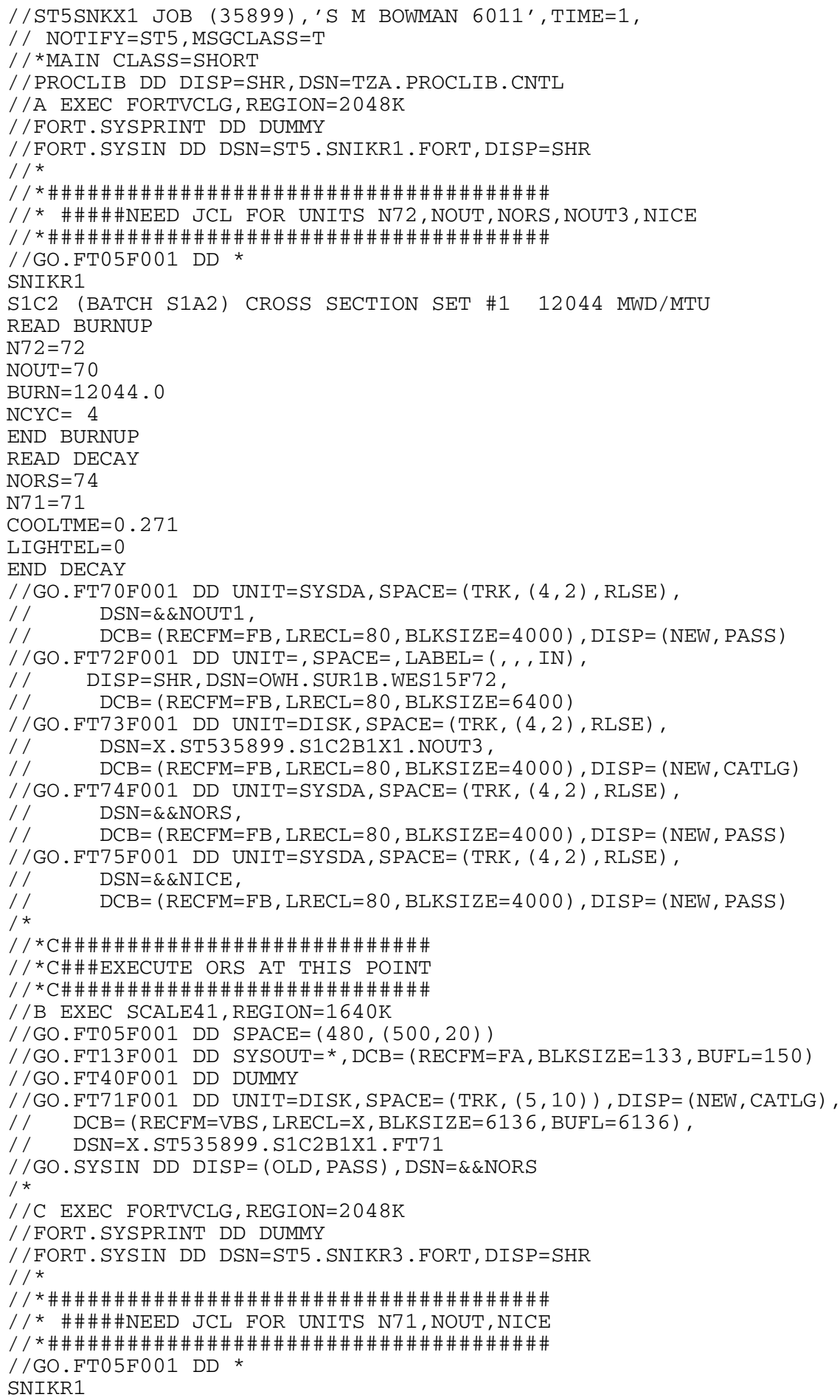




\section{8}

Table D.2. (continued)

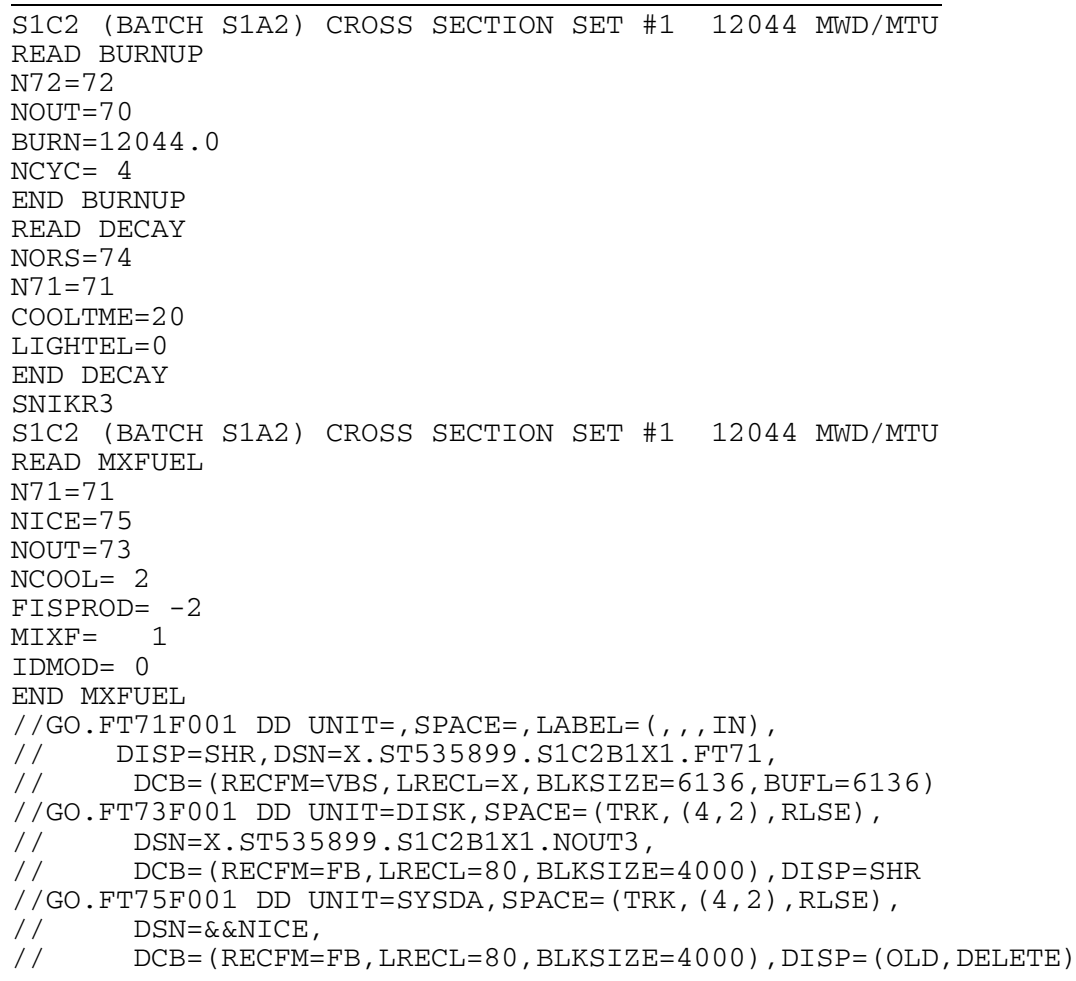


Table D.3. CSASN input for cross-section sets with important actinides only

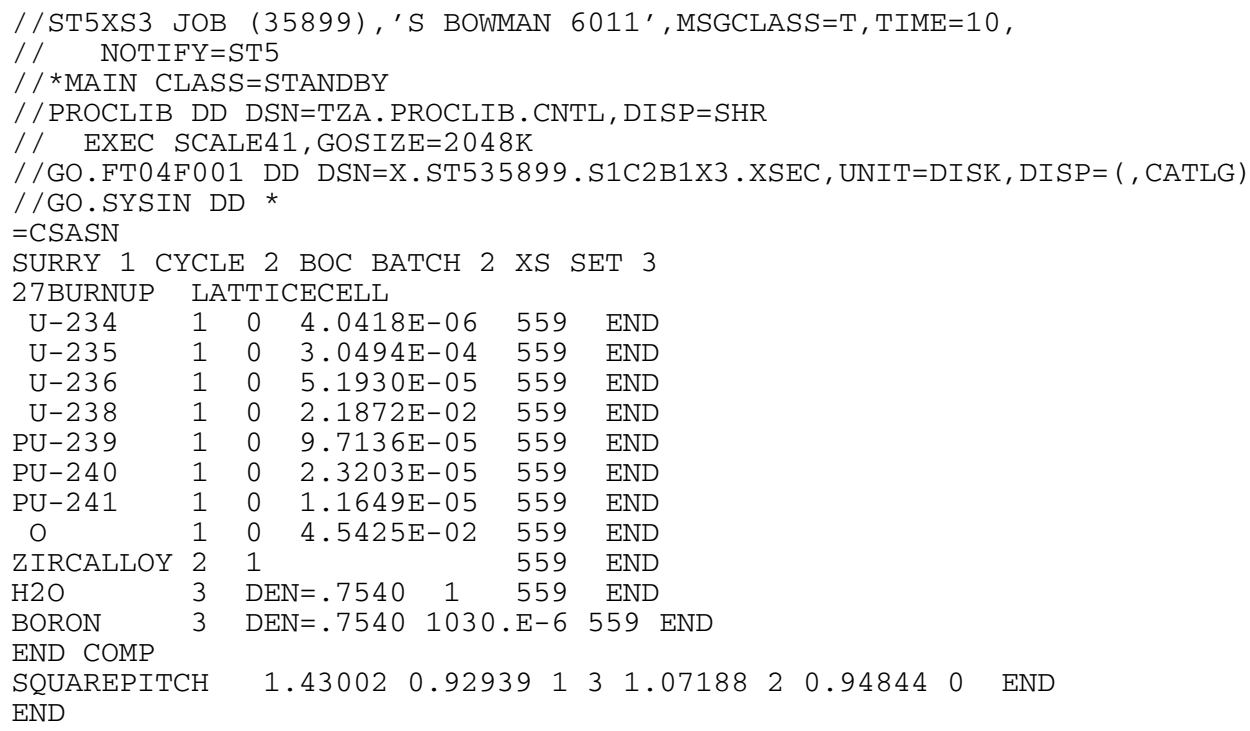


Table D.4. CSASN input for cross-section set 4

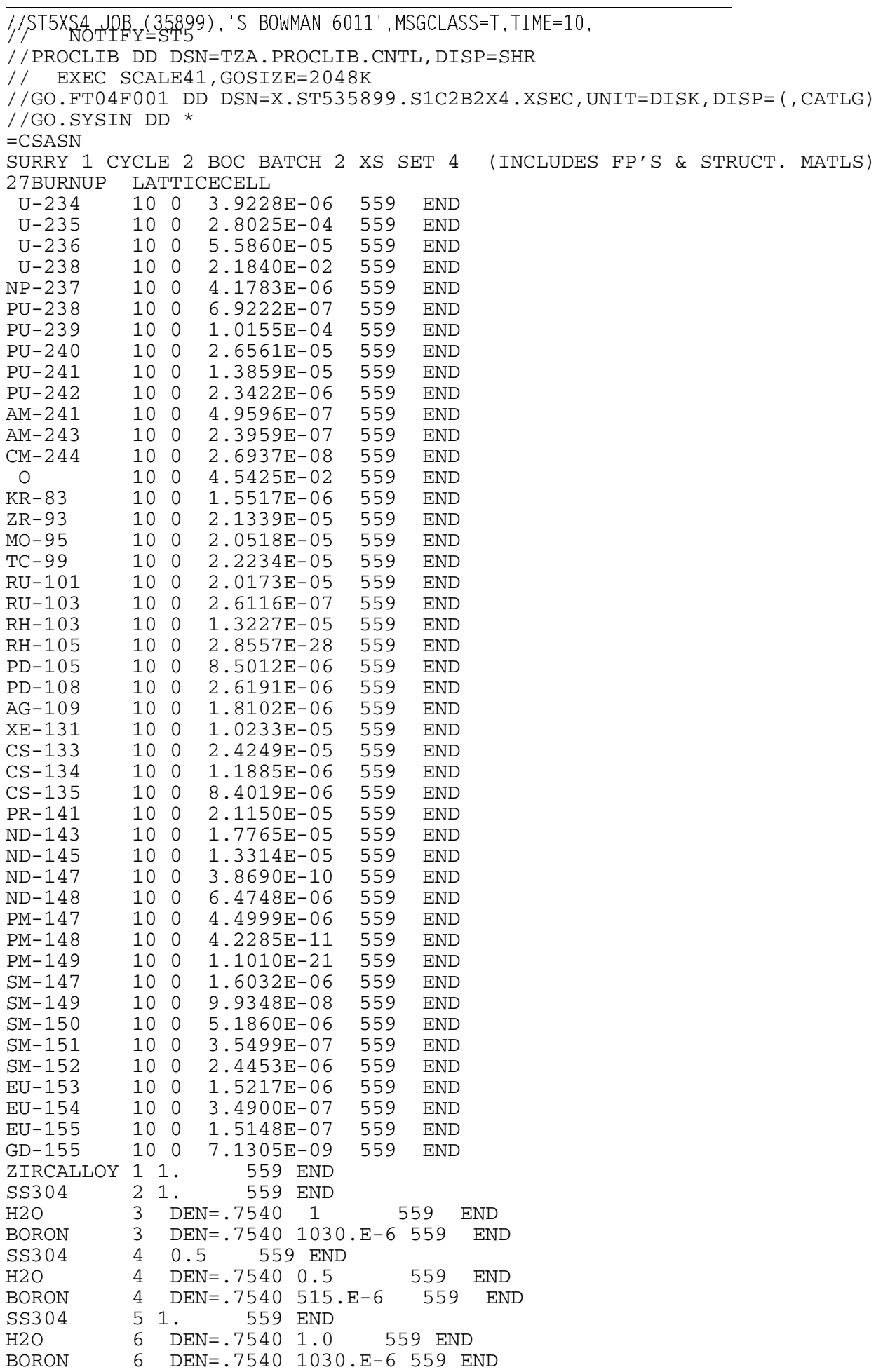


101

Table D.4 (continued)

\begin{tabular}{|c|c|c|c|c|c|}
\hline SS304 & 7 & 559 & END & & \\
\hline $\mathrm{H} 2 \mathrm{O}$ & 8 & $\mathrm{DEN}=.7540$ & 1.0 & 559 END & \\
\hline BORON & 8 & $\mathrm{DEN}=.7540$ & $1030 . E-6$ & 559 END & \\
\hline SS304 & 9 & 559 & END & & \\
\hline $\begin{array}{l}\text { END } \\
\text { SQUAREPITC } \\
\text { END }\end{array}$ & & 1.43002 & 0.9293910 & $\begin{array}{llllll}3 & 1.07188 & 1 & 0.94844 & 0\end{array}$ & END \\
\hline
\end{tabular}


Table D.5. WAX input for cross-section library generation

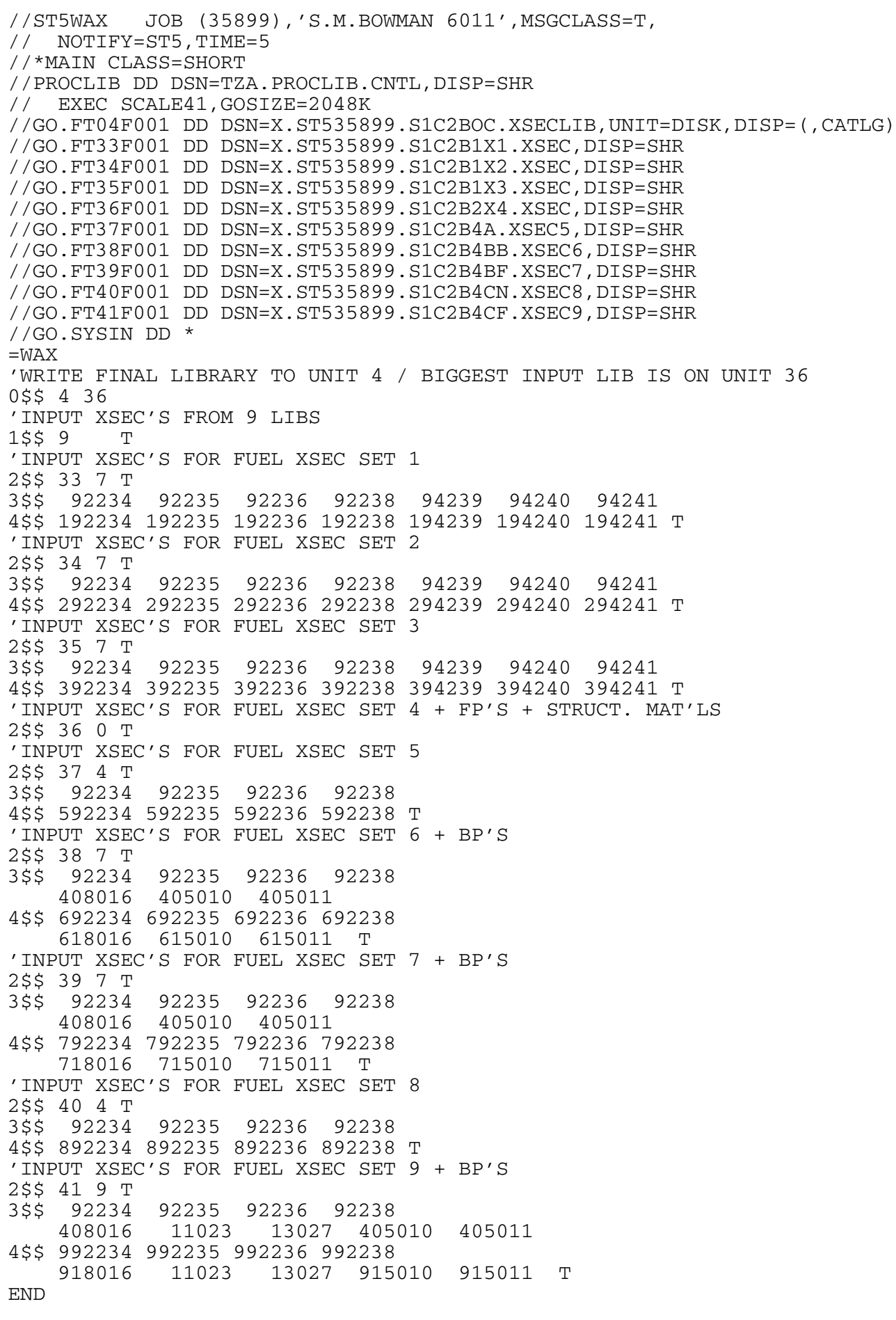


Table D.6. XSDRNPM input for eighth-core assembly location 1

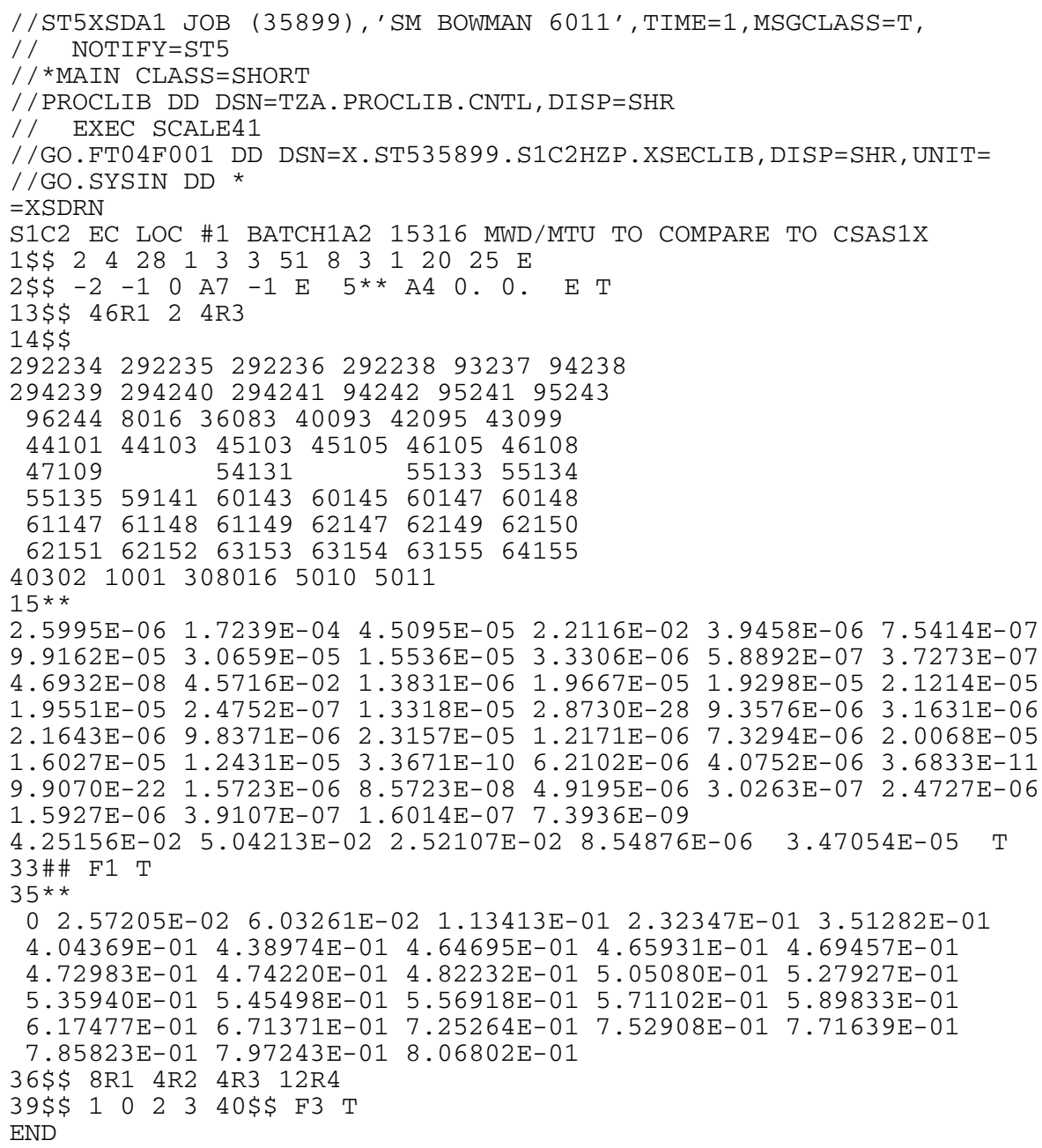


Table D.7. CSAS1X input for eighth-core assembly location 1

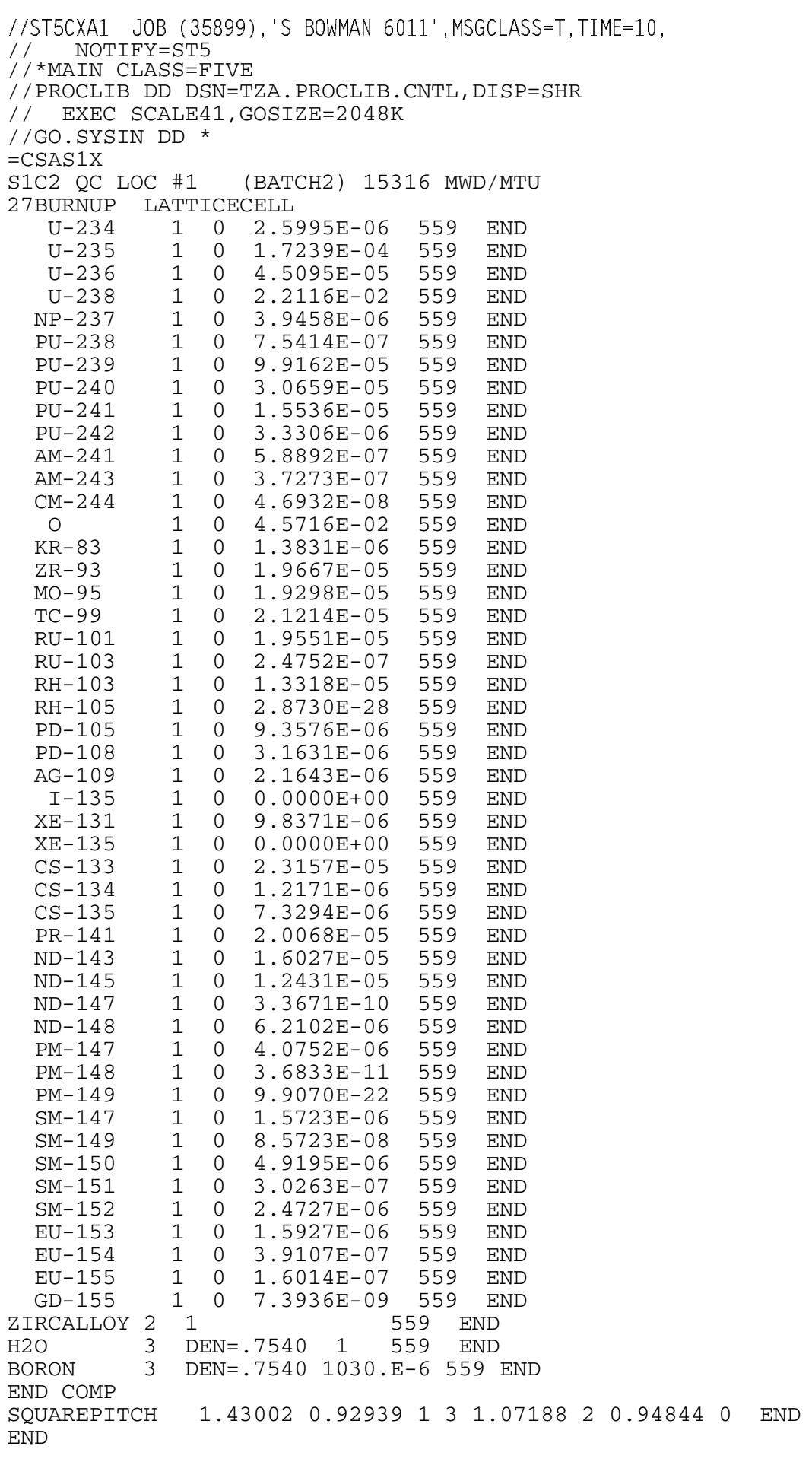


Table D.8. KENO V.a input file for BOC, HZP

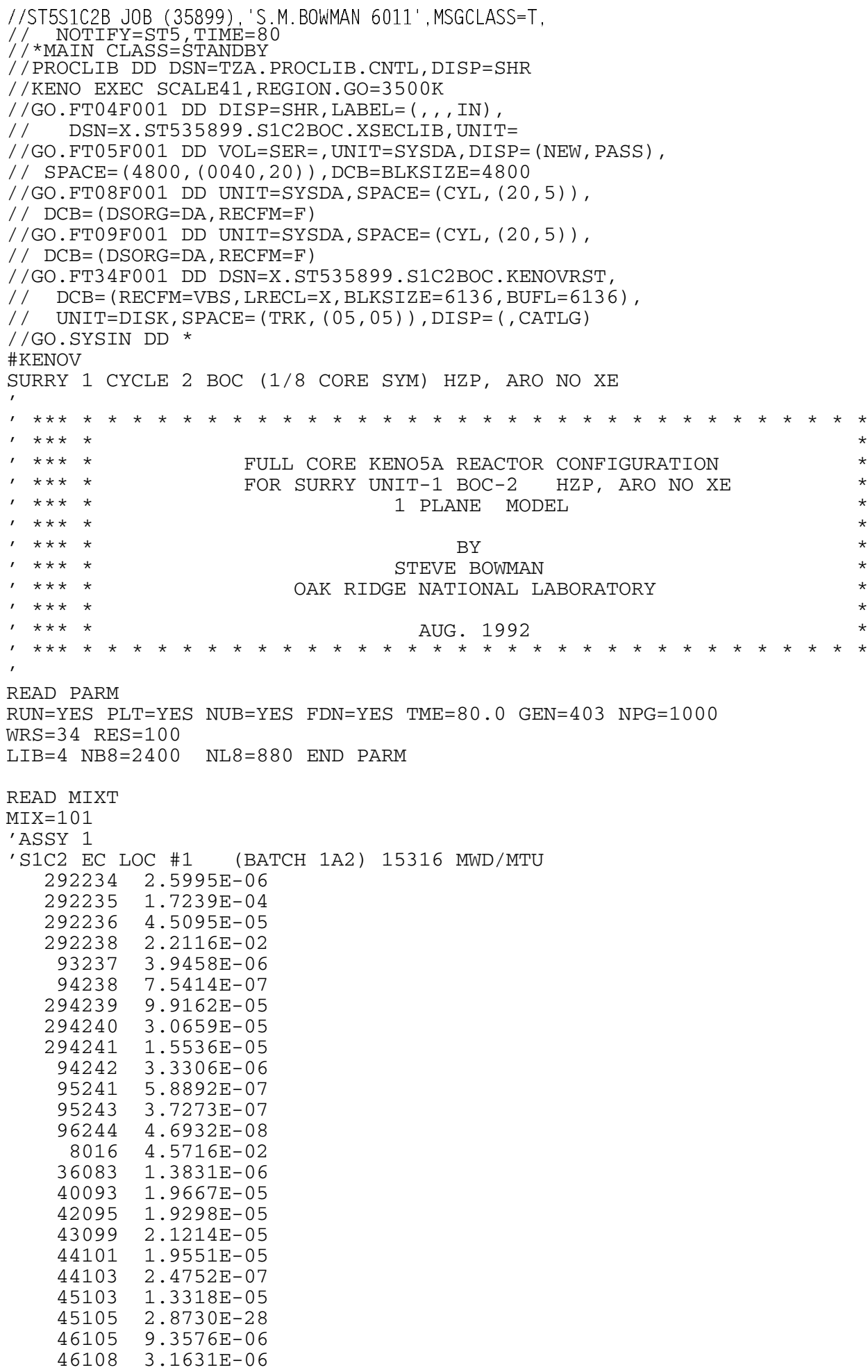


106

Table D.8. (continued)

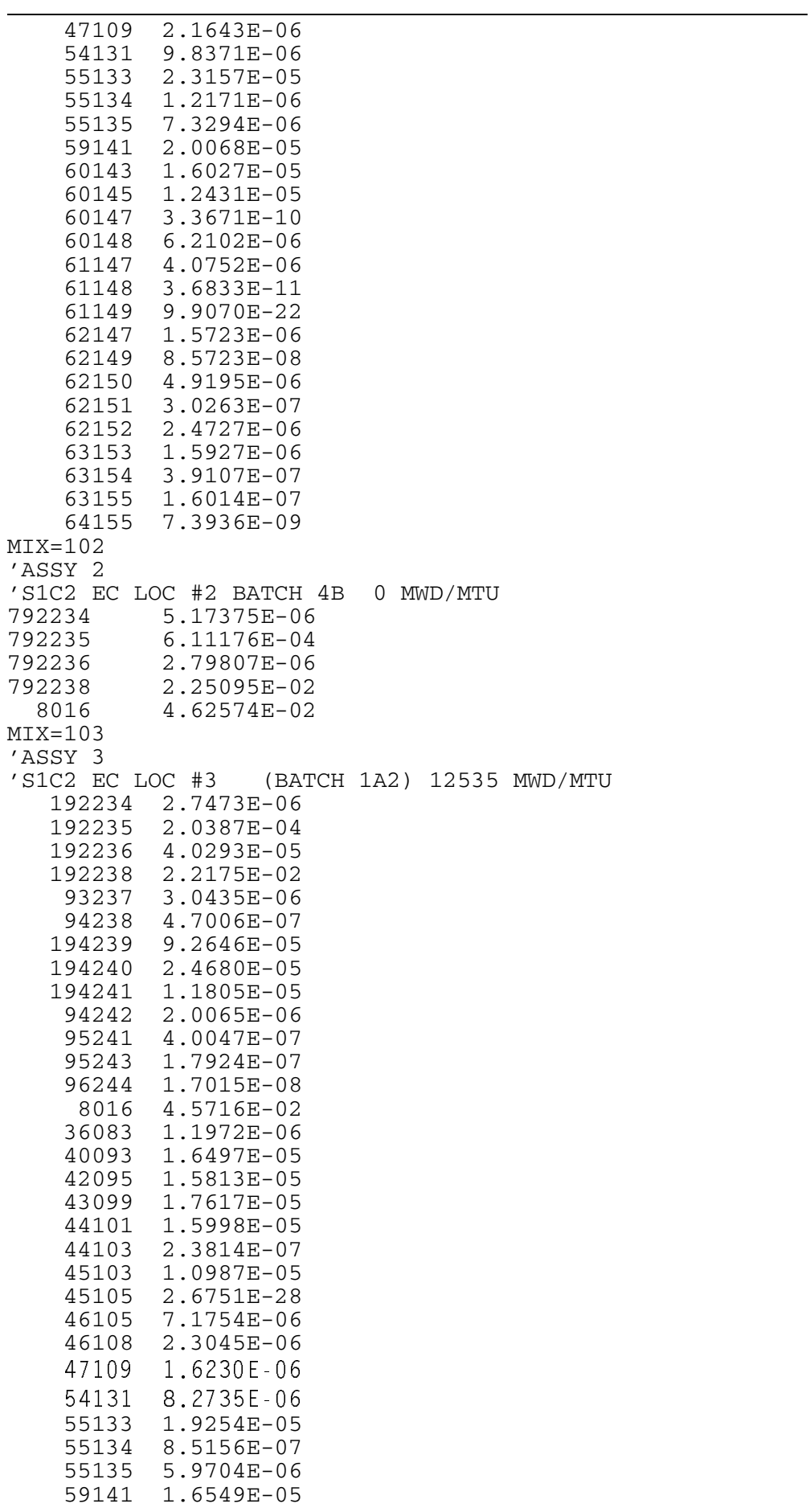


Table D.8. (continued)

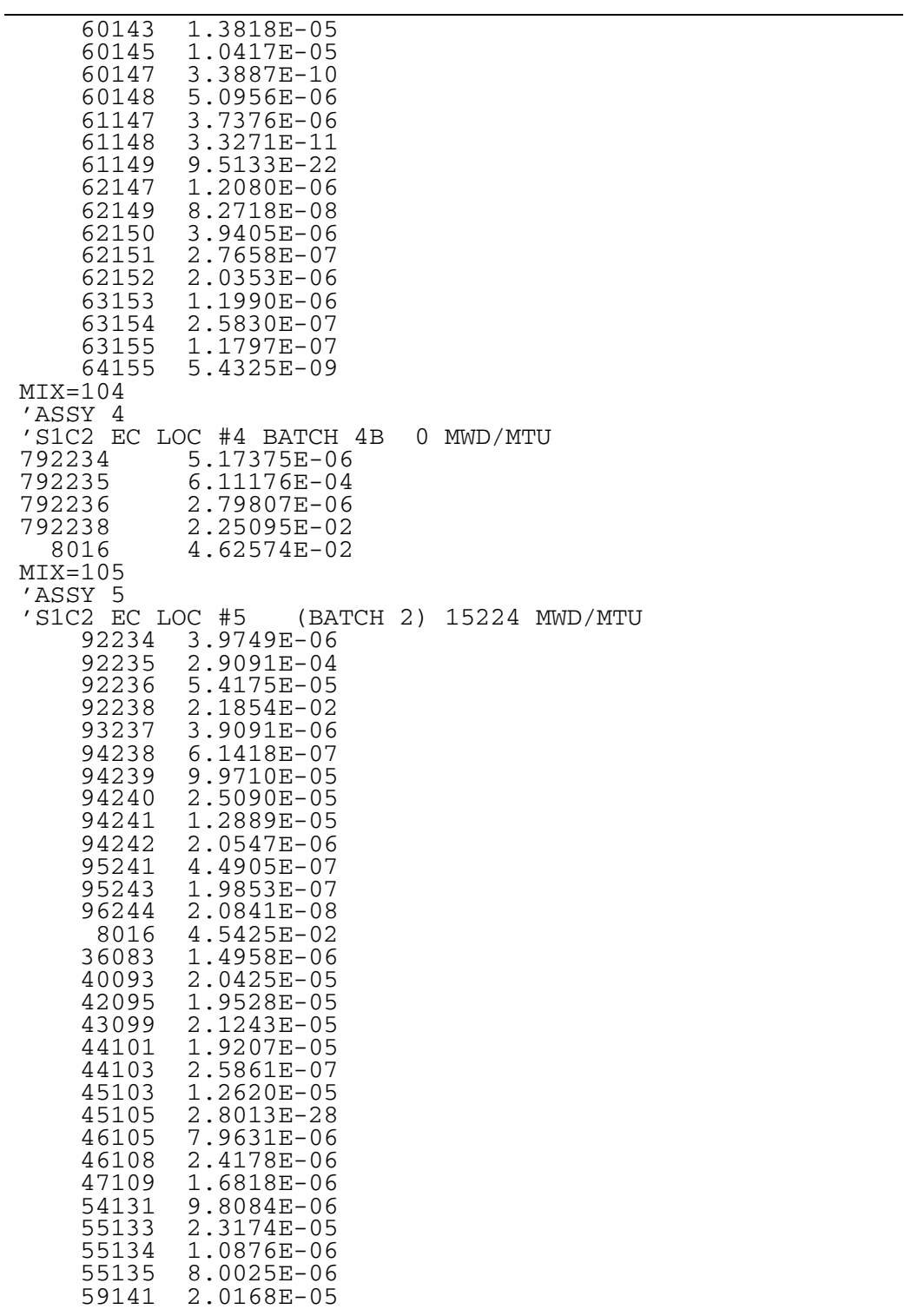


108

Table D.8. (continued)

\begin{tabular}{|c|c|}
\hline 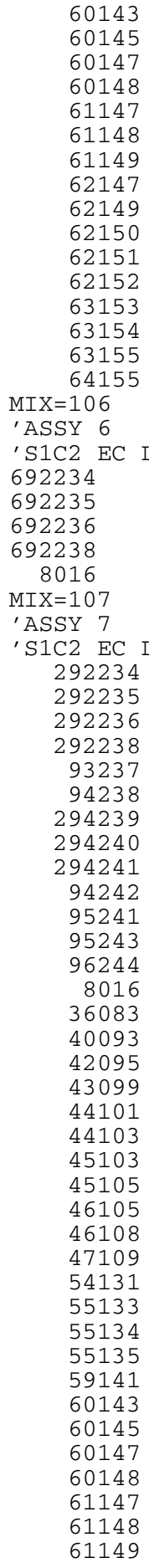 & 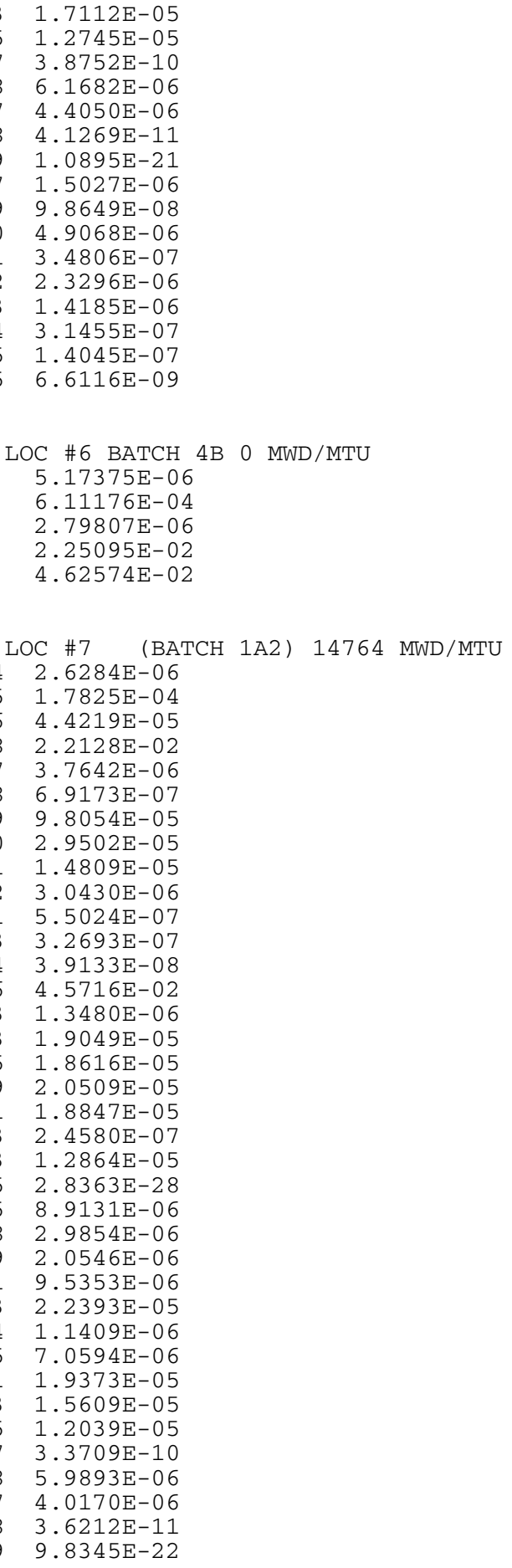 \\
\hline
\end{tabular}


109

Table D.8. (continued)

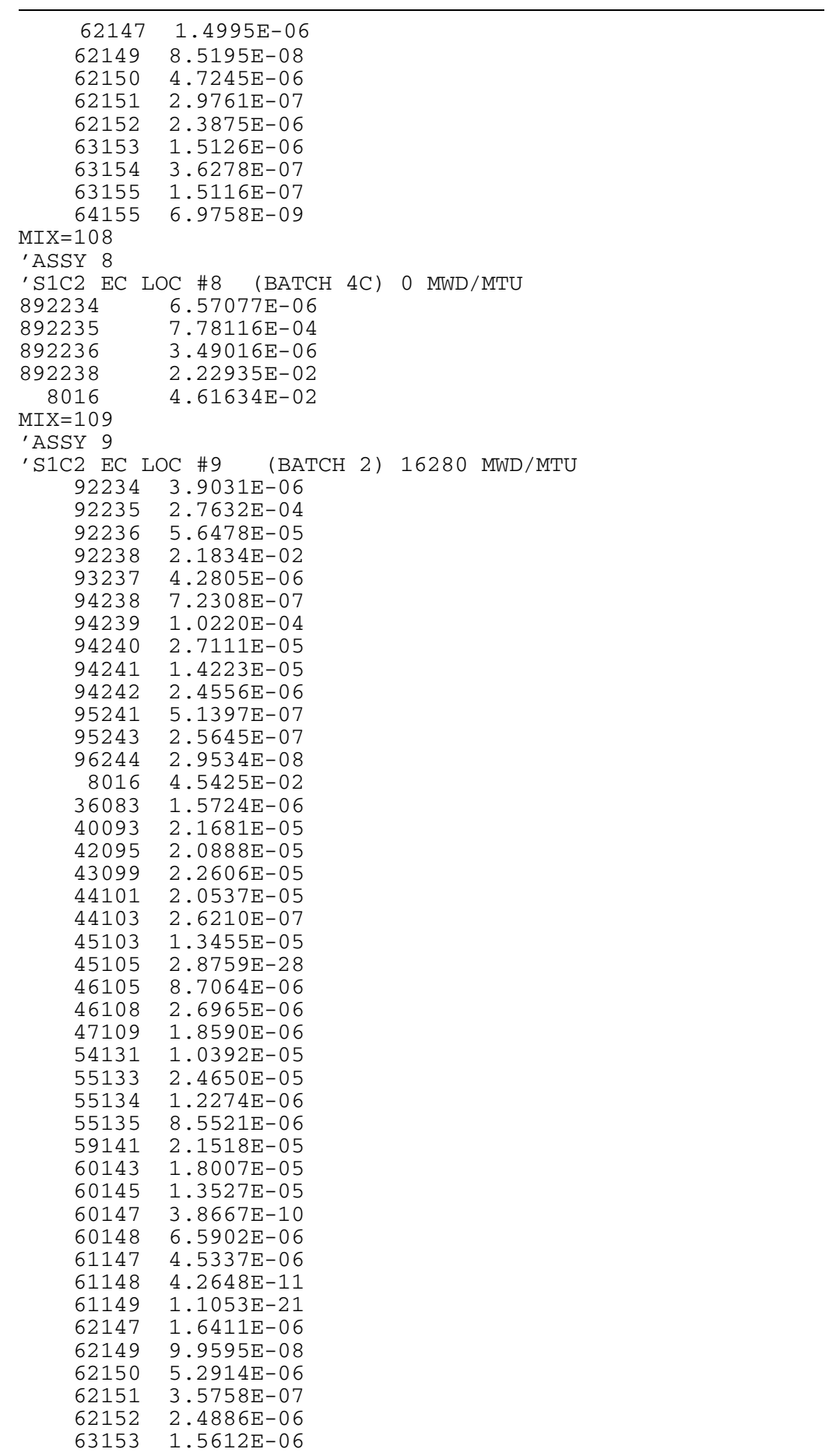


110

Table D.8. (continued)

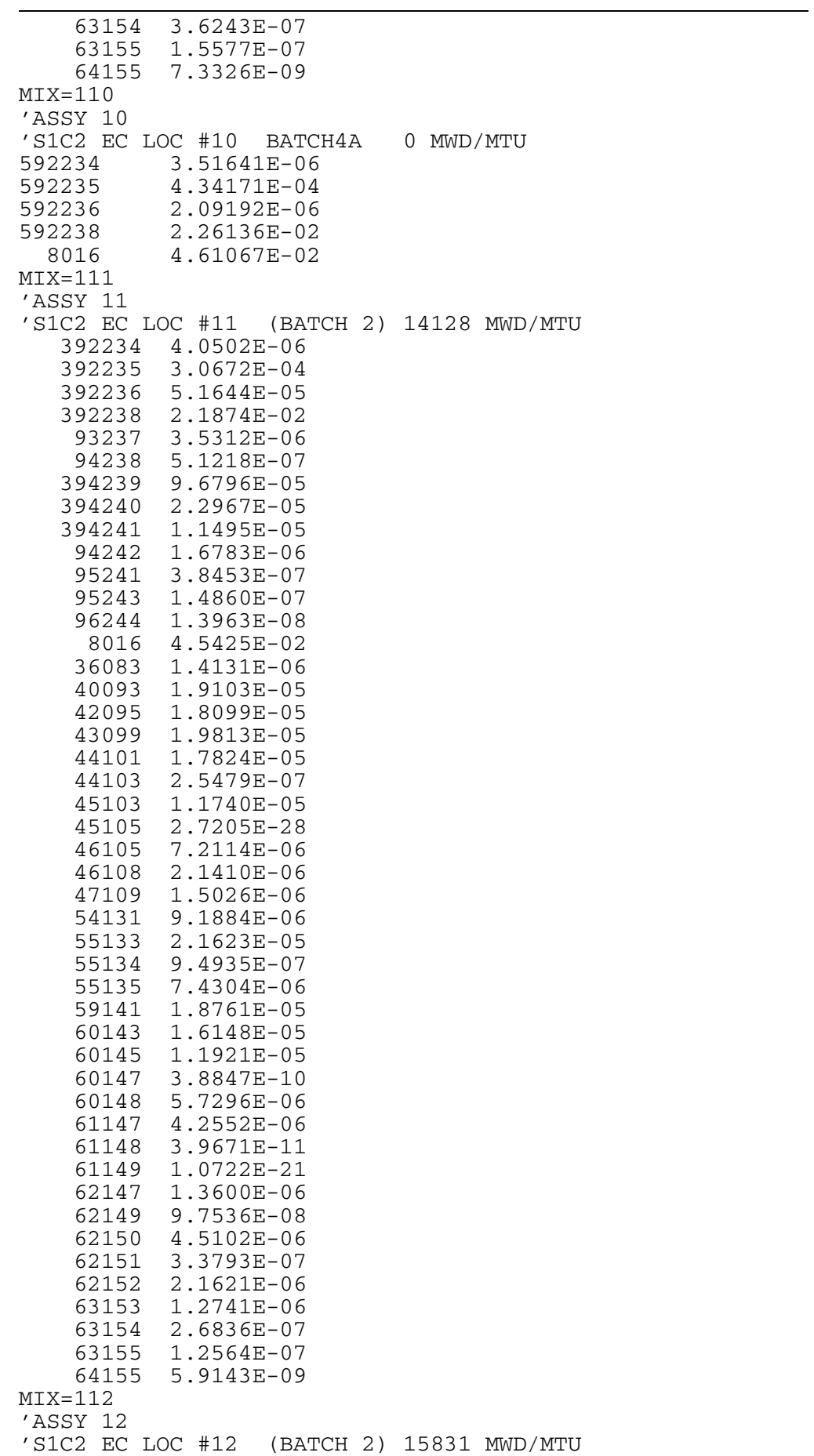


111

Table D.8. (continued)

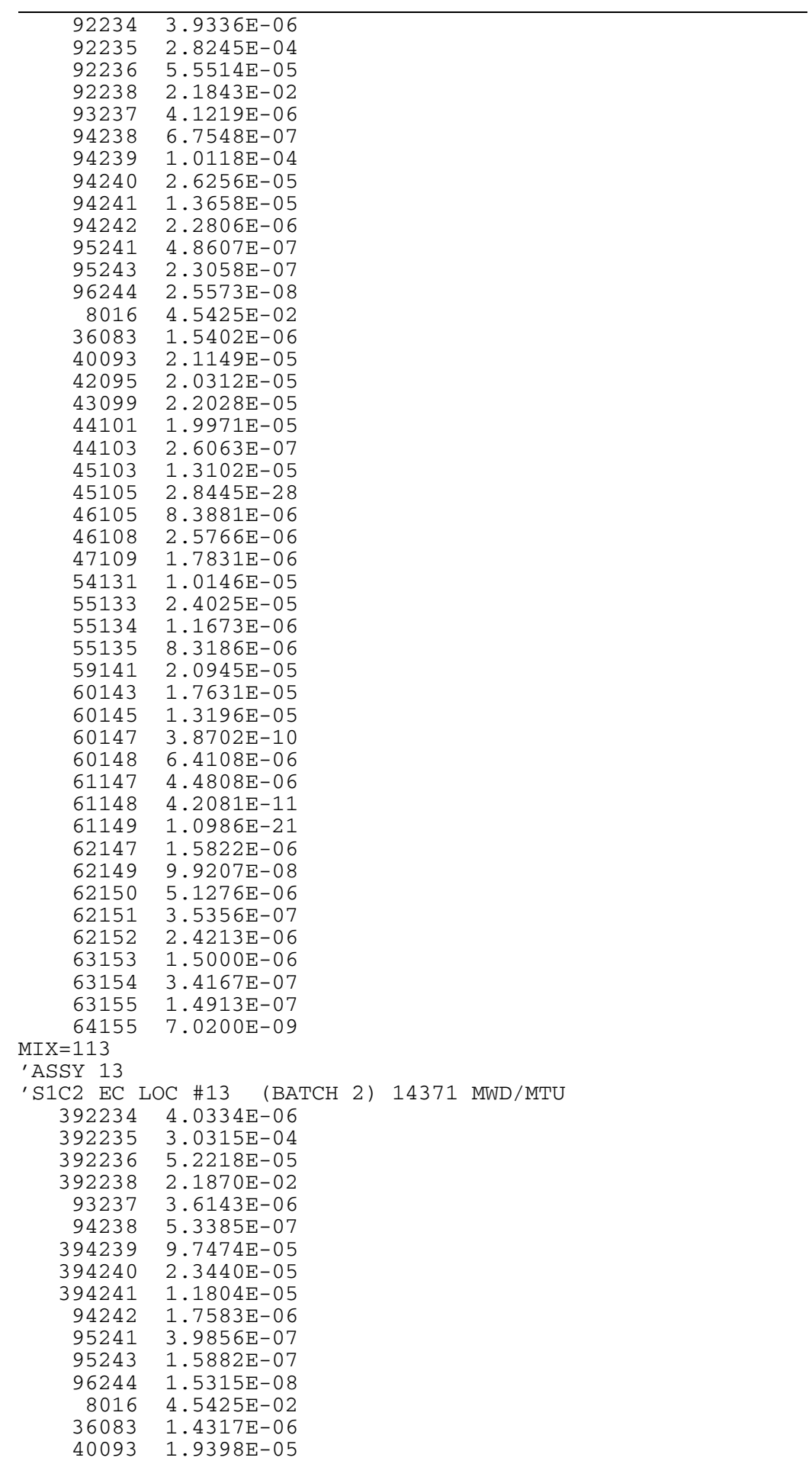


112

Table D.8. (continued)

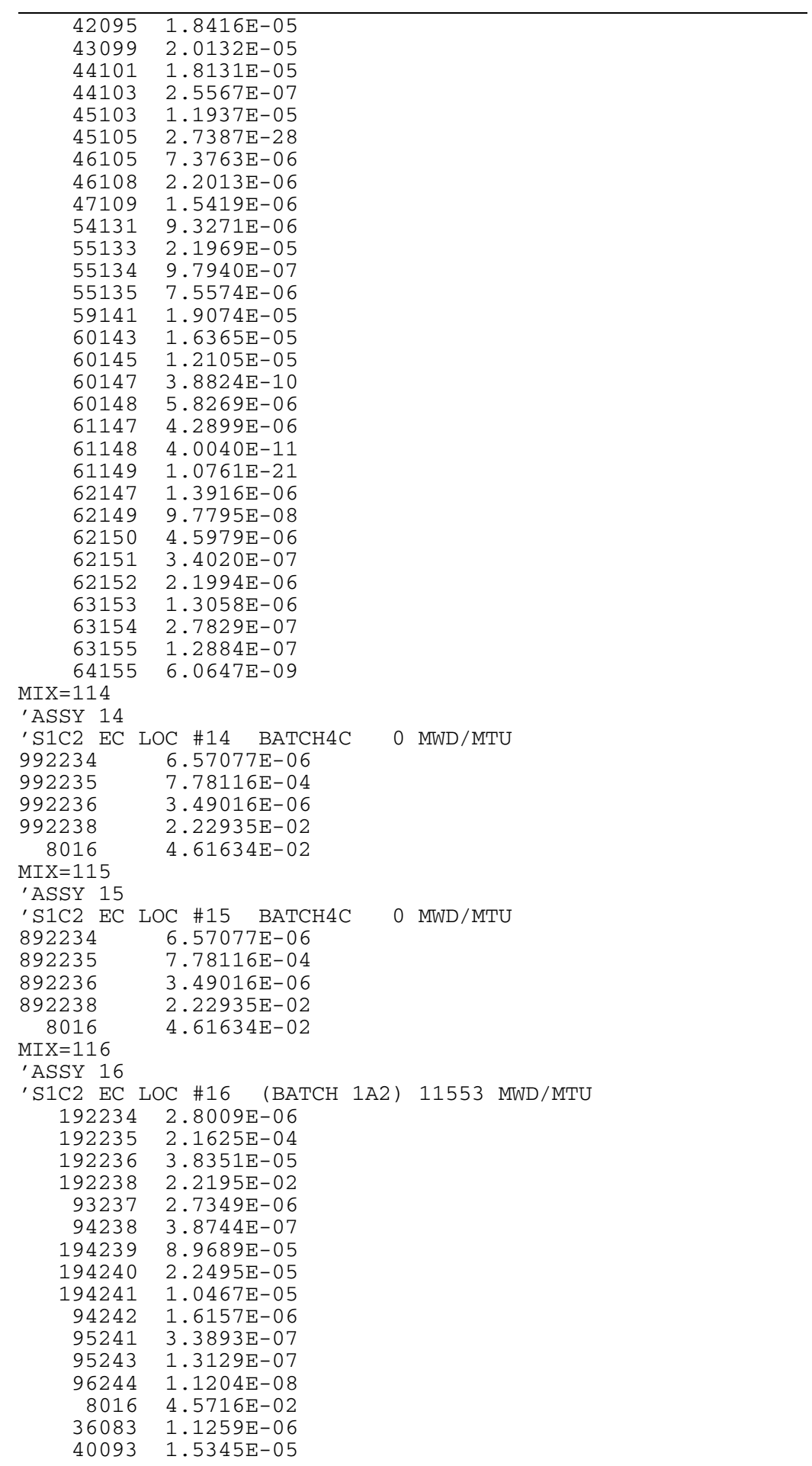


113

Table D.8. (continued)

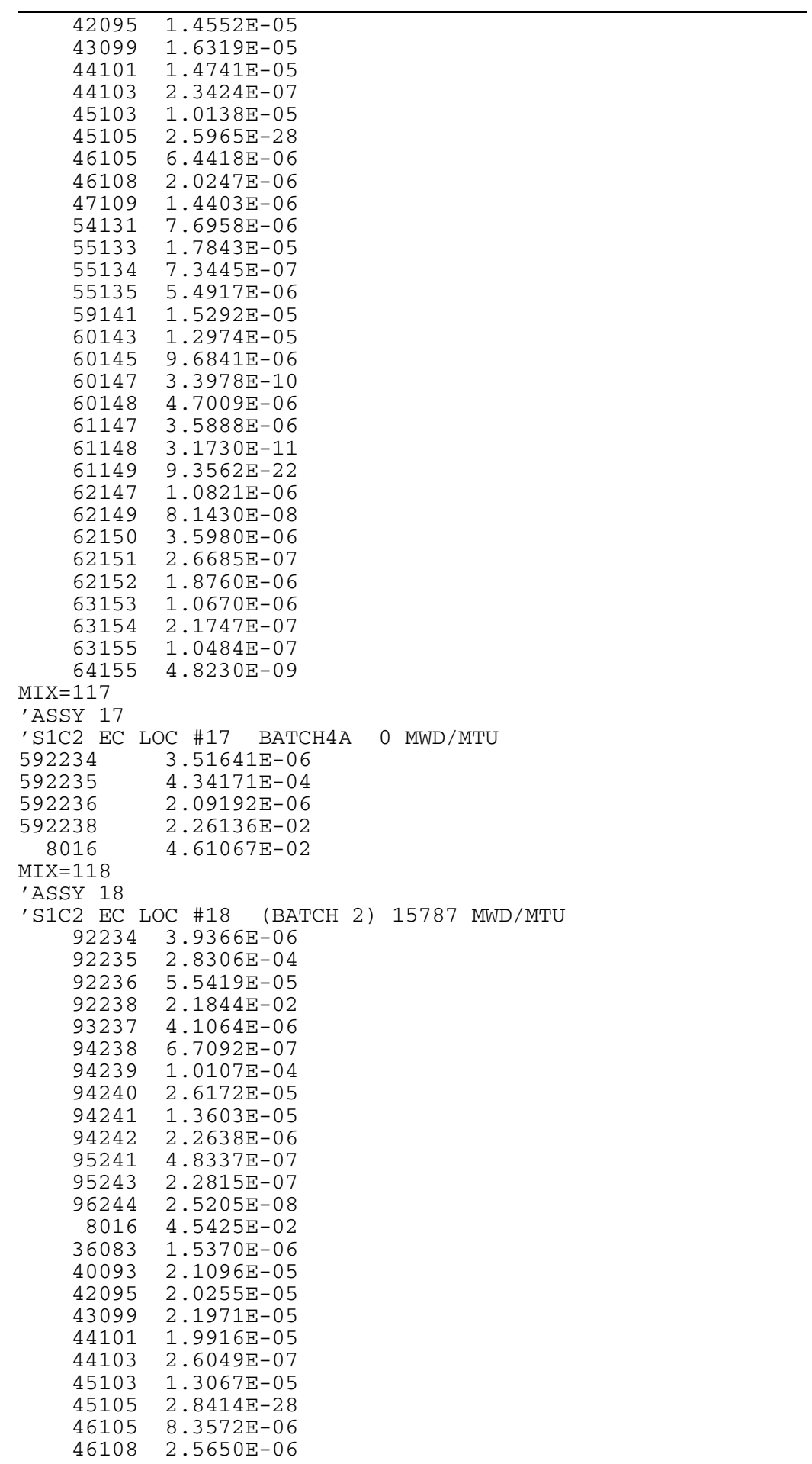




\section{4}

Table D.8. (continued)

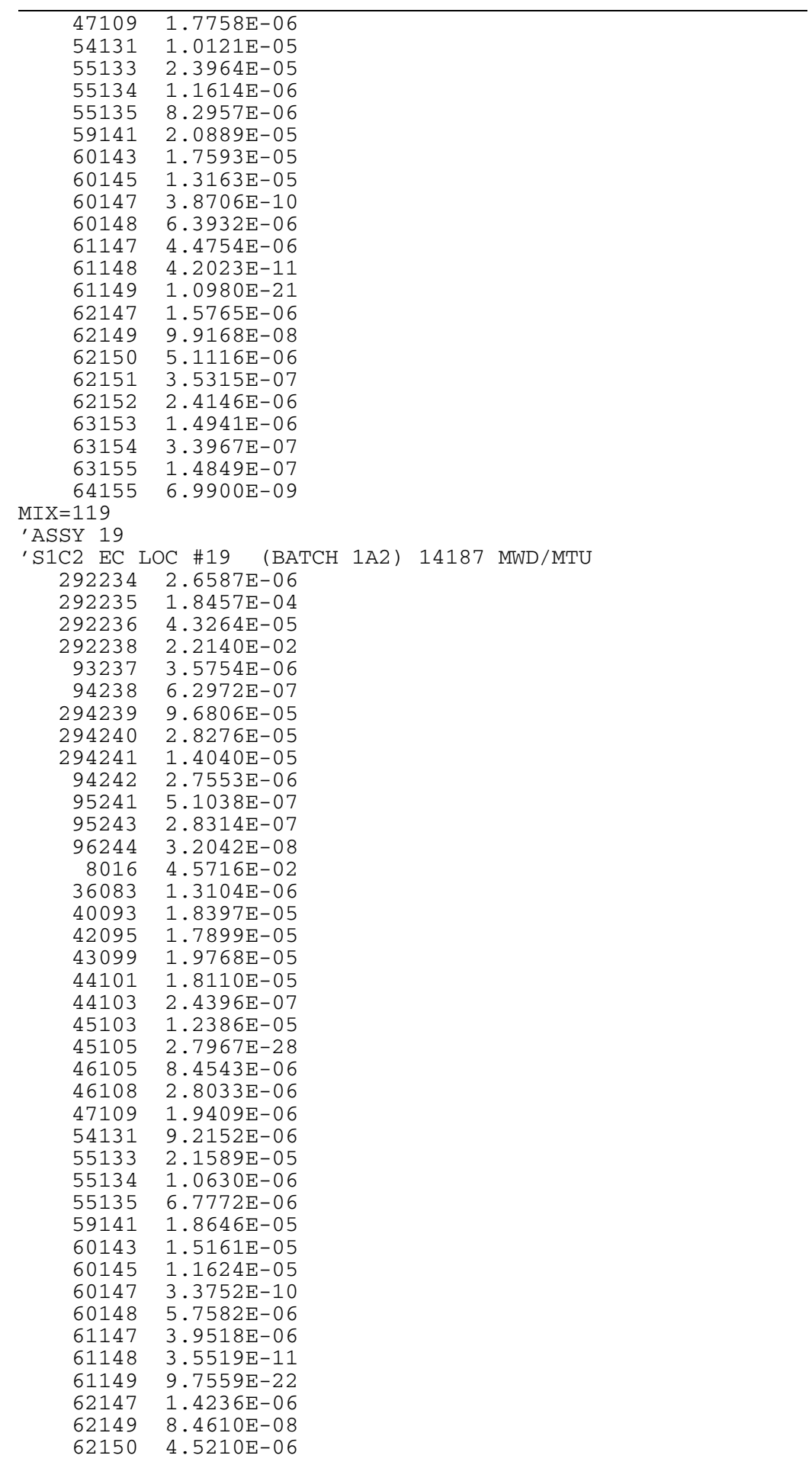


115

Table D.8. (continued)

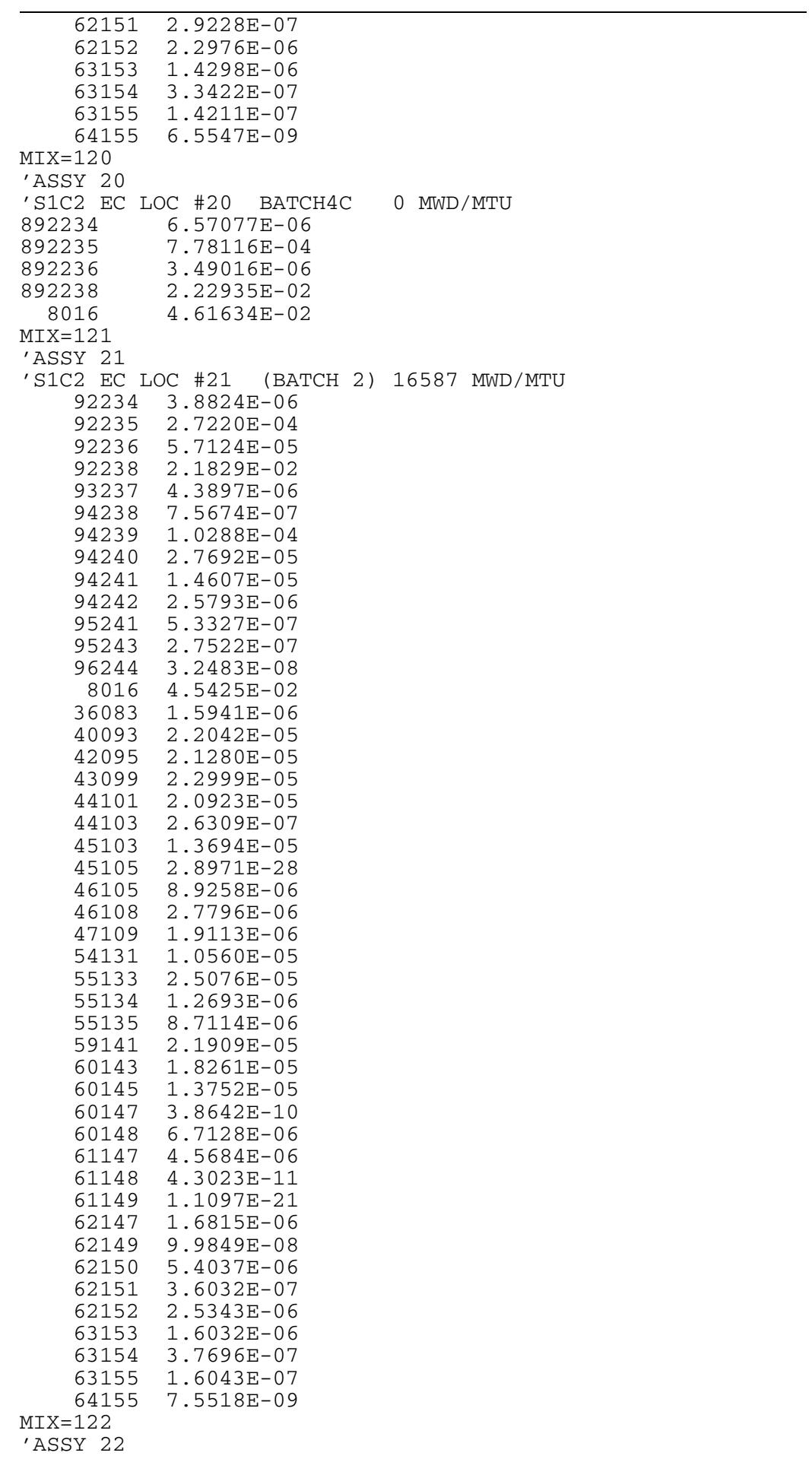


Table D.8. (continued)

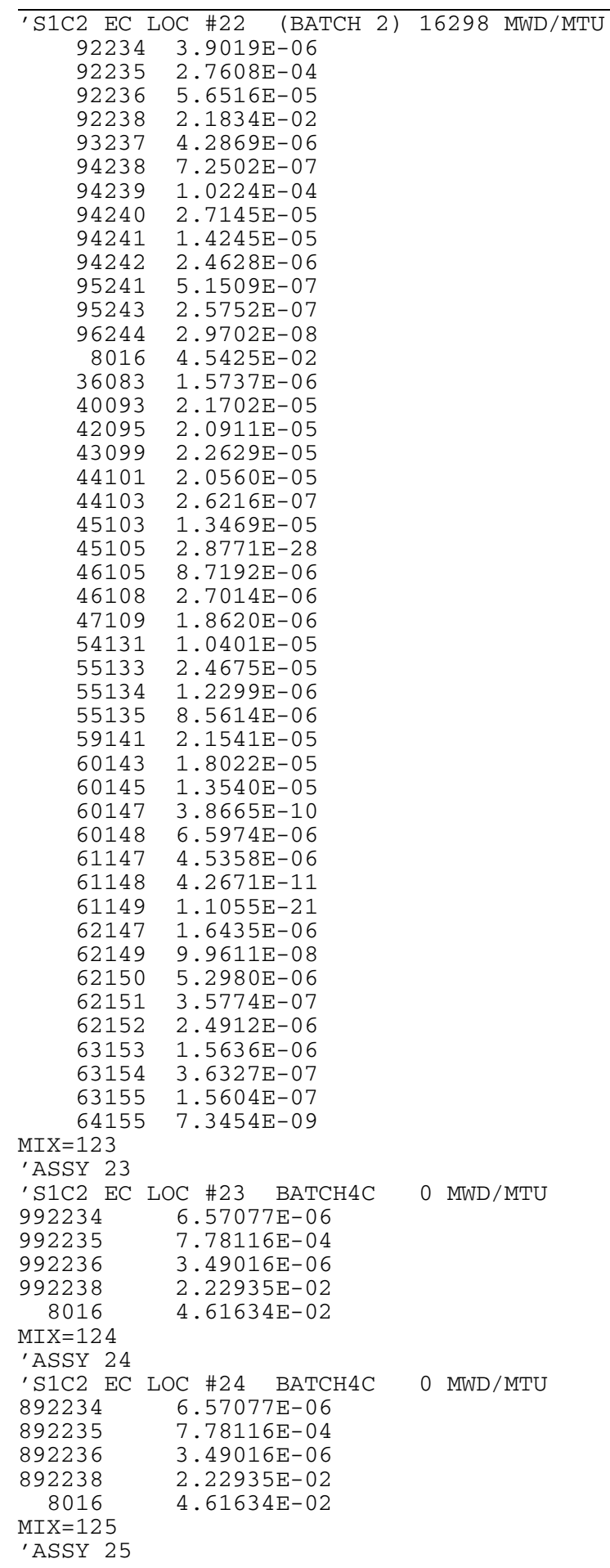


Table D.8. (continued)

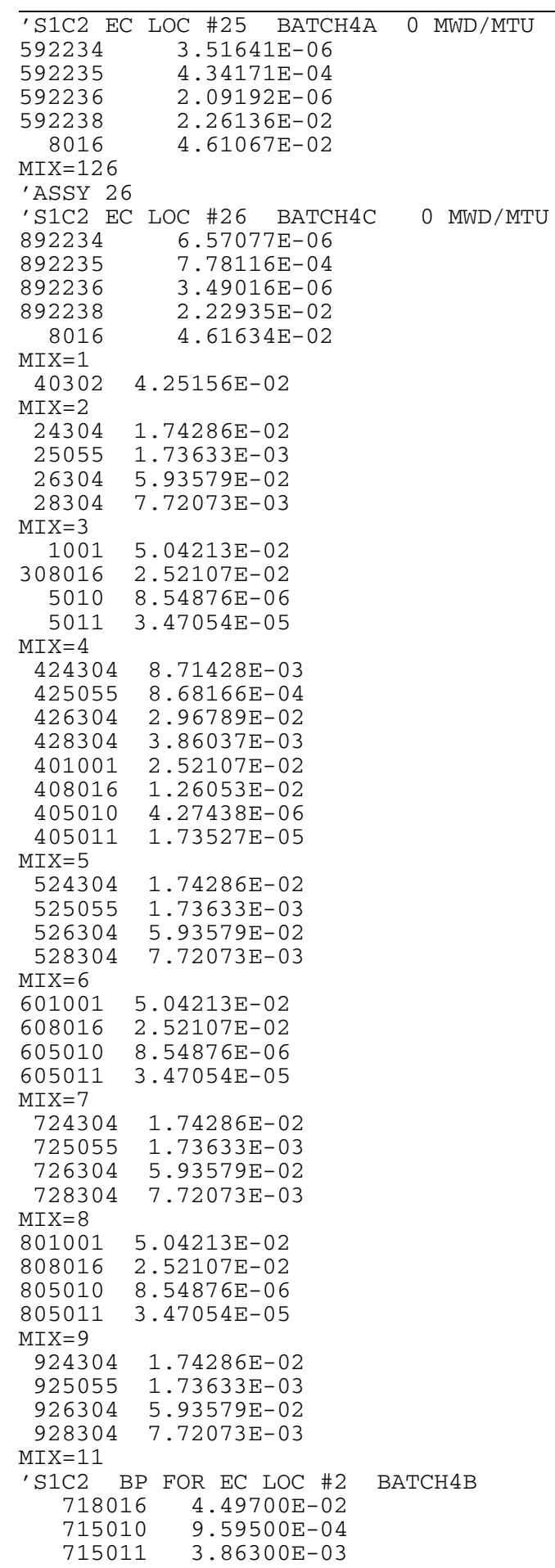


118

Table D.8. (continued)

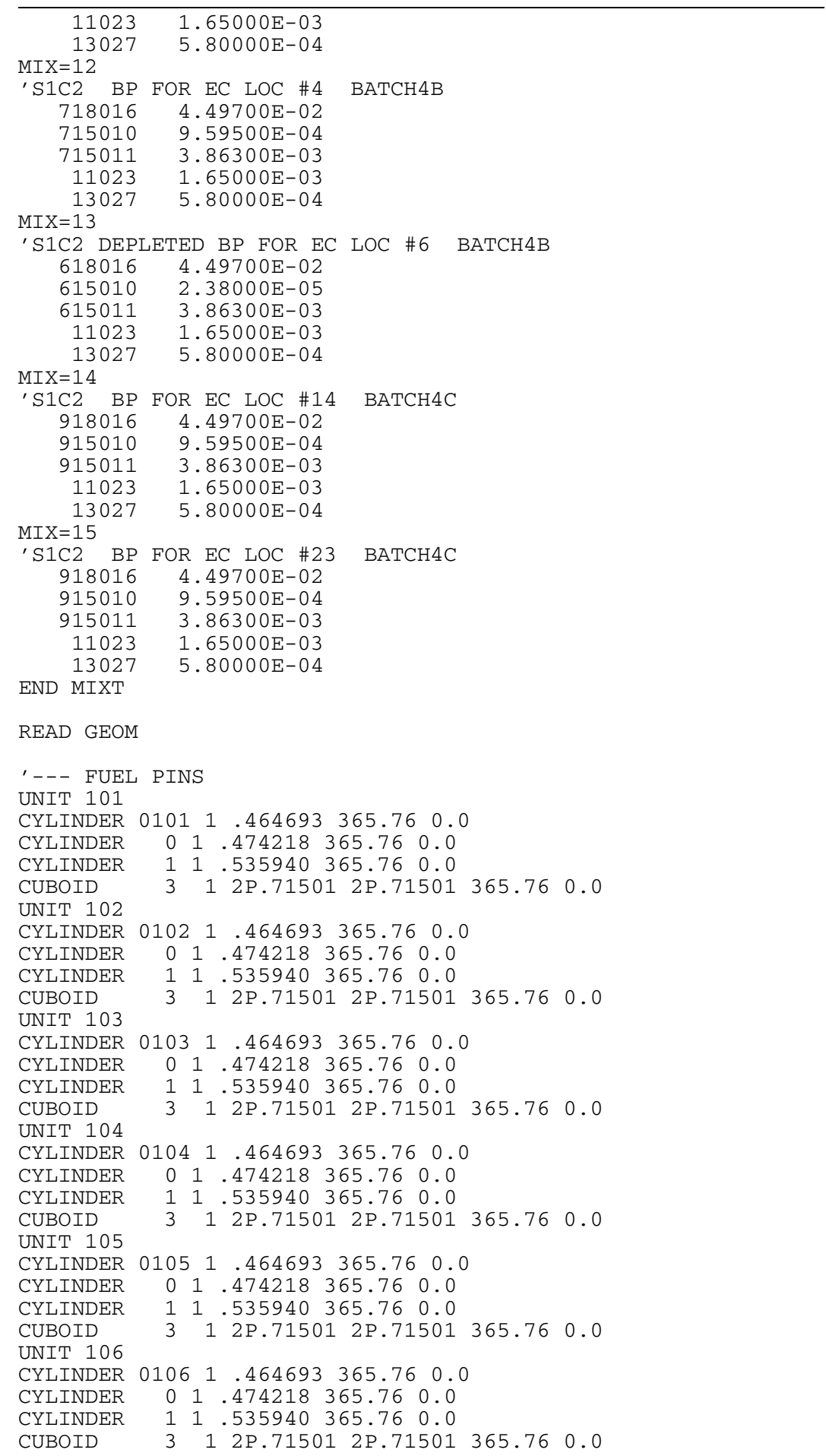


Table D.8. (continued)

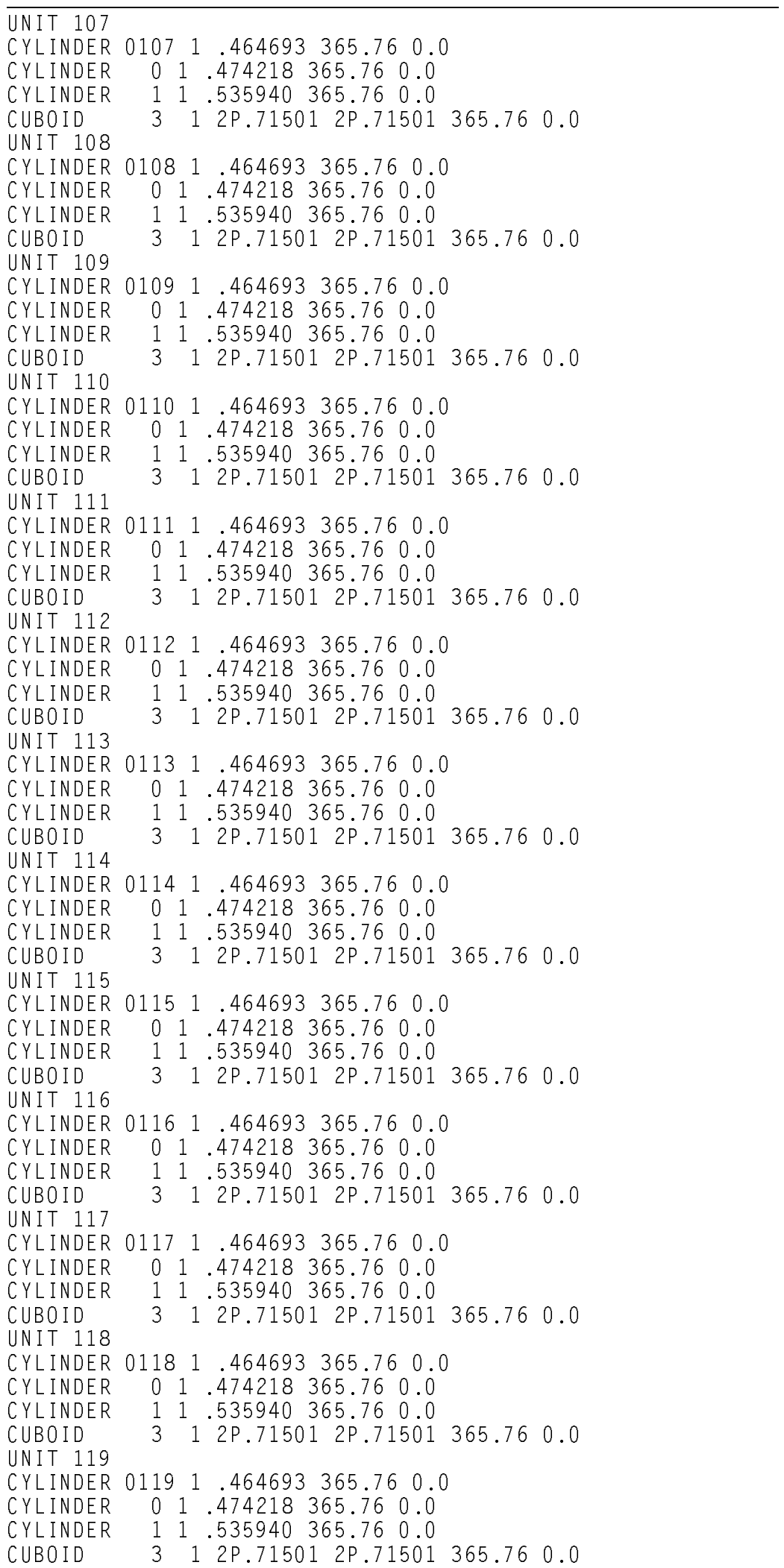


Table D.8. (continued)

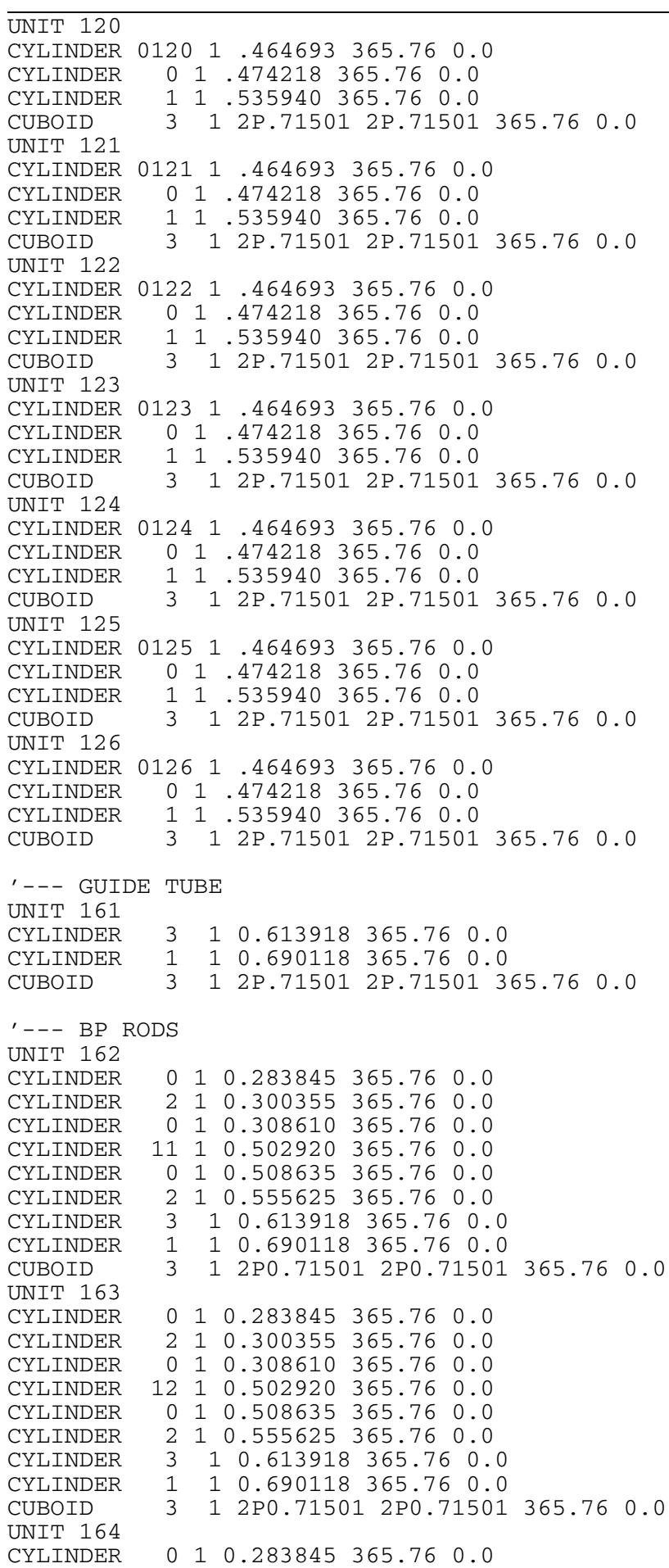


Table D.8. (continued)

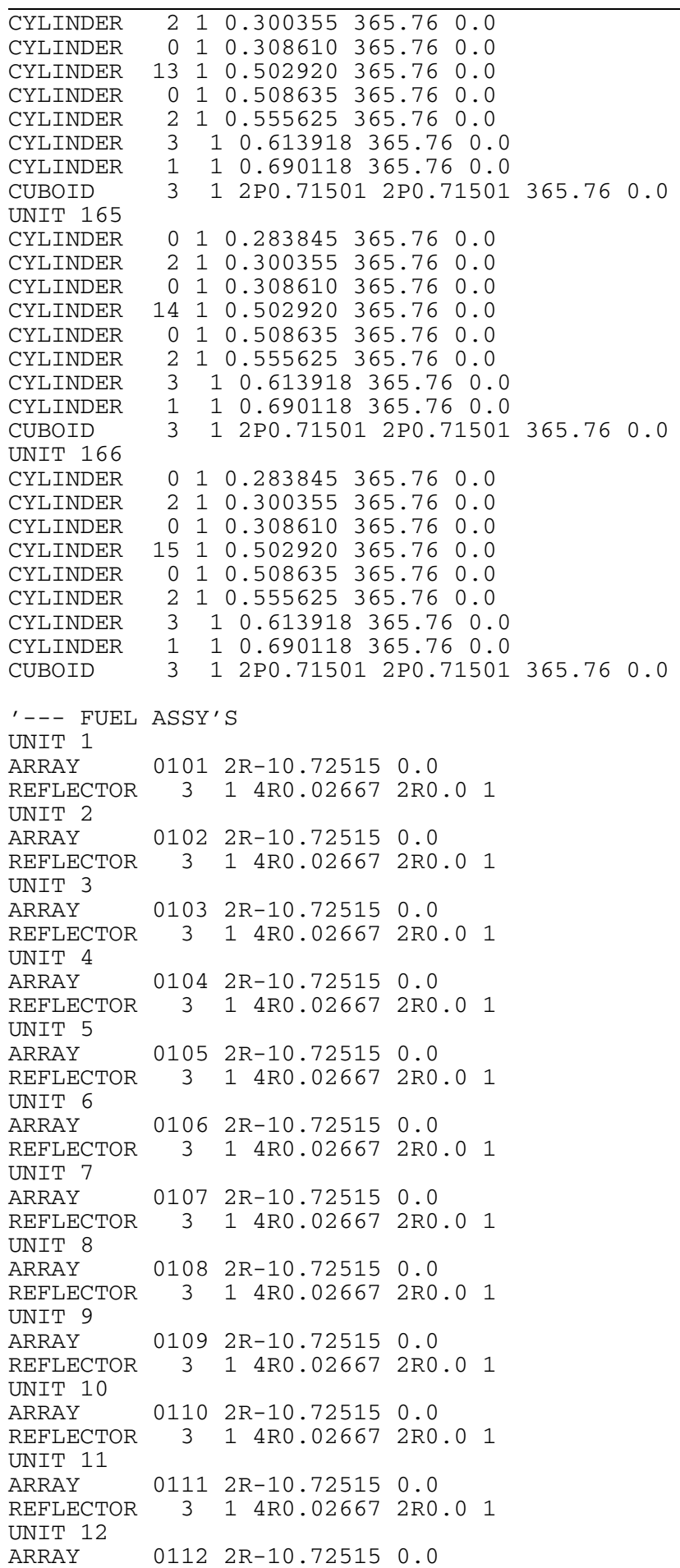


Table D.8. (continued)

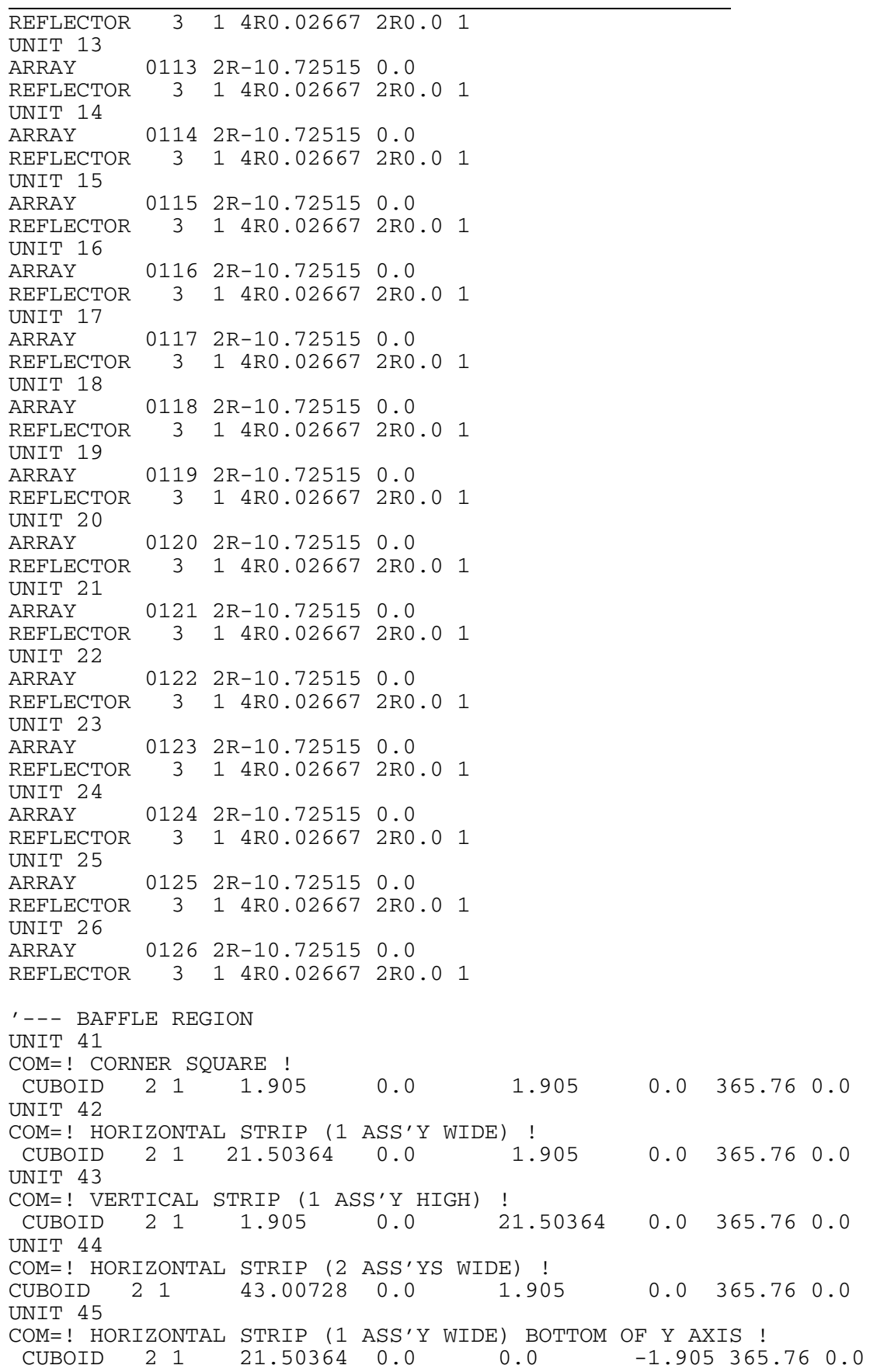


Table D.8. (continued)

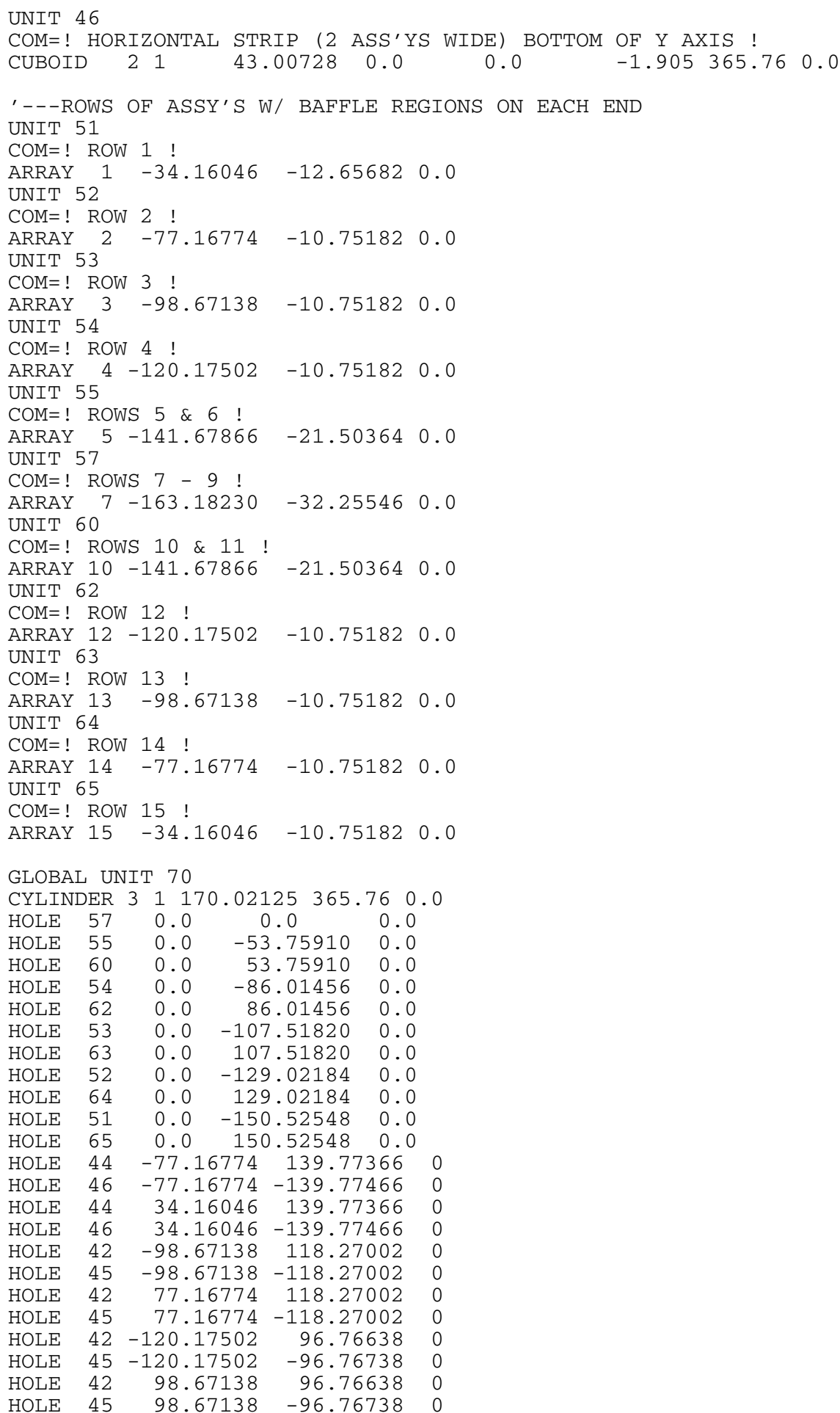


Table D.8. (continued)

\begin{tabular}{|c|c|c|c|c|c|c|c|c|c|}
\hline HOLE & 42 & -141.6786 & & .26274 & 0 & & & & \\
\hline HOLE & 45 & -141.6786 & -75 & .26274 & 0 & & & & \\
\hline HOLE & 42 & 120.1750 & & .26274 & 0 & & & & \\
\hline HOLE & 45 & 120.1750 & -75 & .26274 & 0 & & & & \\
\hline HOLE & 42 & -163.1823 & & .25546 & 0 & & & & \\
\hline HOLE & 45 & -163.1823 & -32 & .25546 & 0 & & & & \\
\hline HOLE & 42 & 141.6786 & & .25546 & 0 & & & & \\
\hline HOLE & 45 & 141.6786 & $66-32$ & .25546 & 50 & & & & \\
\hline CYLIND & DER 4 & 41170.0 & 021253 & 90.76 & -25 . & & & & \\
\hline REFLEC & CTOR & 515 . & .08 & 0.00. & 01 & & & & \\
\hline REFLEC & CTOR & 616. & .0325 & 0.00. & 01 & & & & \\
\hline REFLEC & CTOR & 716 & .82625 & 0.0 & 01 & & & & \\
\hline REFLEC & CTOR & 8111 & .43 & 0.00. & 01 & & & & \\
\hline REFLEC & CTOR & 9119. & .89582 & 0.00. & 01 & & & & \\
\hline CUBOID & D 0 & $12 \mathrm{P} 220$. & $0 \quad 2 \mathrm{P} 22$ & $0.0 \quad 39$ & 0.76 & -25.0 & & & \\
\hline END GE & $\mathrm{EOM}$ & & & & & & & & \\
\hline READ A & $A R R A Y$ & & & & & & & & \\
\hline$'---F$ & FUEL & ASSY'S & & & & & & & \\
\hline $\mathrm{ARA}=10$ & & $\mathrm{NUX}=15 \mathrm{~N}$ & $\mathrm{NUY}=15$ & $\mathrm{NUZ}=1$ & & FILL F10 & & & \\
\hline A33 & 161 & A3 6 & 161 & A40 & 161 & A43 & 161 & & \\
\hline A53 & 161 & A65 & 161 & A71 & 161 & A78 & 161 & & \\
\hline A88 & 161 & A109 & 161 & A113 & 161 & A117 & 161 & A138 & 161 \\
\hline A148 & 161 & A155 & 161 & A161 & 161 & A173 & 161 & & \\
\hline A183 & 161 & A186 & 161 & A190 & 161 & A193 & 161 & END & FILL \\
\hline $\mathrm{ARA}=10$ & & $\mathrm{NUX}=15 \mathrm{~N}$ & $N U Y=15$ & $N U Z=1$ & & & & & \\
\hline $\mathrm{COM}=/$ & AS & SSY 2 -- & 8 FRES & $\mathrm{SH} \mathrm{BP}$ & / & & & & \\
\hline A33 & $\begin{array}{l}161 \\
162\end{array}$ & A3 6 & 162 & A 40 & 162 & A43 & 161 & & \\
\hline A53 & 161 & A 65 & 161 & A71 & 161 & A78 & 162 & & \\
\hline A 88 & 162 & A109 & 161 & A113 & 161 & A117 & 161 & A138 & 162 \\
\hline A148 & 162 & A155 & 161 & A161 & 161 & A173 & 161 & & \\
\hline A183 & 161 & A186 & 162 & A190 & 162 & A193 & 161 & END & FILL \\
\hline$A R A=10$ & & $\mathrm{NUX}=15 \mathrm{~N}$ & $N U Y=15$ & $\mathrm{NUZ}=1$ & & FILL F10 & & & \\
\hline A33 & 161 & A3 6 & 161 & A4 0 & 161 & A 43 & 161 & & \\
\hline A53 & 161 & A65 & 161 & A71 & 161 & A78 & 161 & & \\
\hline A 88 & 161 & A109 & 161 & A113 & 161 & A117 & 161 & A138 & 161 \\
\hline A148 & 161 & A155 & 161 & A161 & 161 & A173 & 161 & & \\
\hline A183 & 161 & A186 & 161 & A190 & 161 & A193 & 161 & END & FILL \\
\hline $\mathrm{ARA}=10$ & & $\mathrm{NUX}=15 \mathrm{~N}$ & NUY=15 & $\mathrm{NUZ}=1$ & & & & & \\
\hline $\mathrm{COM}=/$ & AS & SSY $4--$ & 8 FRES & $\mathrm{SH} \quad \mathrm{BP}$ & / & & & & \\
\hline A33 & 161 & A3 6 & 163 & $\mathrm{~A} 40$ & 163 & A43 & 161 & & \\
\hline A5 3 & 161 & A65 & 161 & A71 & 161 & A78 & 163 & & \\
\hline A88 & 163 & A109 & 161 & A113 & 161 & A 117 & 161 & A138 & 163 \\
\hline A148 & 163 & A155 & 161 & A161 & 161 & A173 & 161 & & \\
\hline A183 & 161 & A186 & 163 & A190 & 163 & A193 & 161 & END & FILL \\
\hline $\mathrm{ARA}=10$ & & $N U X=15 \mathrm{~N}$ & $N U Y=15$ & $N U Z=1$ & & FILL F10 & & & \\
\hline A33 & 161 & A3 6 & 161 & A40 & 161 & A43 & 161 & & \\
\hline A53 & 161 & A65 & 161 & A71 & 161 & A78 & 161 & & \\
\hline A 88 & 161 & A109 & 161 & A113 & 161 & A117 & 161 & A138 & 161 \\
\hline A148 & 161 & A155 & 161 & A161 & 161 & A173 & 161 & & \\
\hline A183 & 161 & A186 & 161 & A190 & 161 & A193 & 161 & END & FILL \\
\hline $\mathrm{ARA}=10$ & & $\mathrm{NUX}=15 \mathrm{~N}$ & NUY=15 & $\mathrm{NUZ}=1$ & & & & & \\
\hline $\mathrm{COM}=/$ & AS & SSY $6--$ & $12 \mathrm{DEP}$ & PLETED & $\mathrm{BP}$ & / & & & \\
\hline $\begin{array}{c}\text { FILL F } \\
\text { A33 }\end{array}$ & 7106 & A 36 & 164 & A 40 & 164 & & & & \\
\hline A5 3 & 161 & A65 & 161 & A71 & 161 & $\begin{array}{l}\text { A43 } \\
\text { A78 }\end{array}$ & $\begin{array}{l}164 \\
164\end{array}$ & & \\
\hline A 88 & 164 & A109 & 161 & A113 & 161 & A11 7 & 161 & A138 & 164 \\
\hline A148 & 164 & A155 & 161 & A161 & 161 & A173 & 161 & & \\
\hline A183 & 164 & A186 & 164 & A190 & 164 & A193 & 164 & END & FILL \\
\hline $\mathrm{ARA}=10$ & & $\mathrm{NUX}=15 \mathrm{~N}$ & $\mathrm{NUY}=15$ & $N U Z=1$ & & FILL F10 & & & \\
\hline A33 & 161 & A3 6 & 161 & A4 0 & 161 & A43 & 161 & & \\
\hline A 53 & 161 & A 65 & 161 & A71 & 161 & A78 & 161 & & \\
\hline
\end{tabular}


Table D.8. (continued)

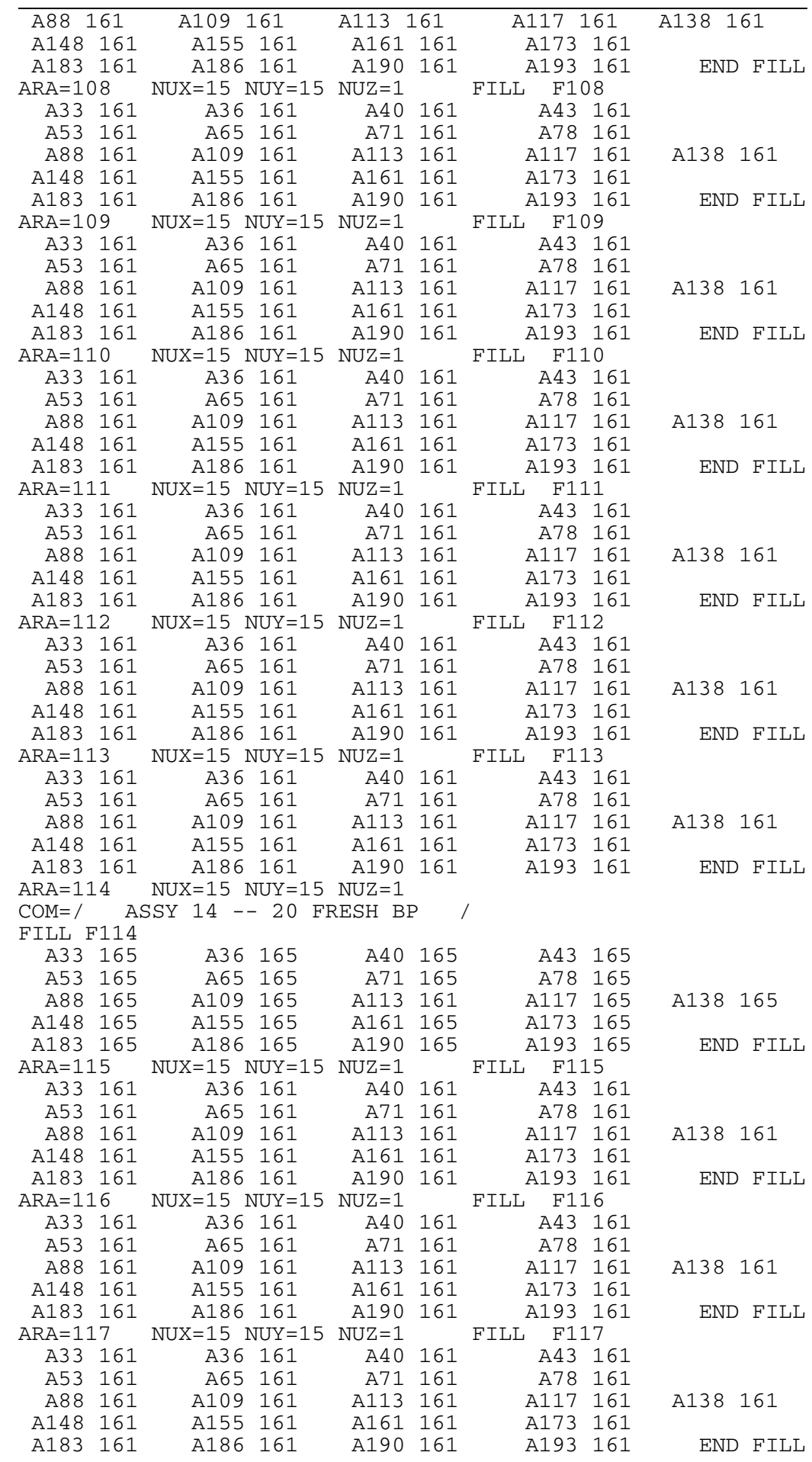


Table D.8. (continued)

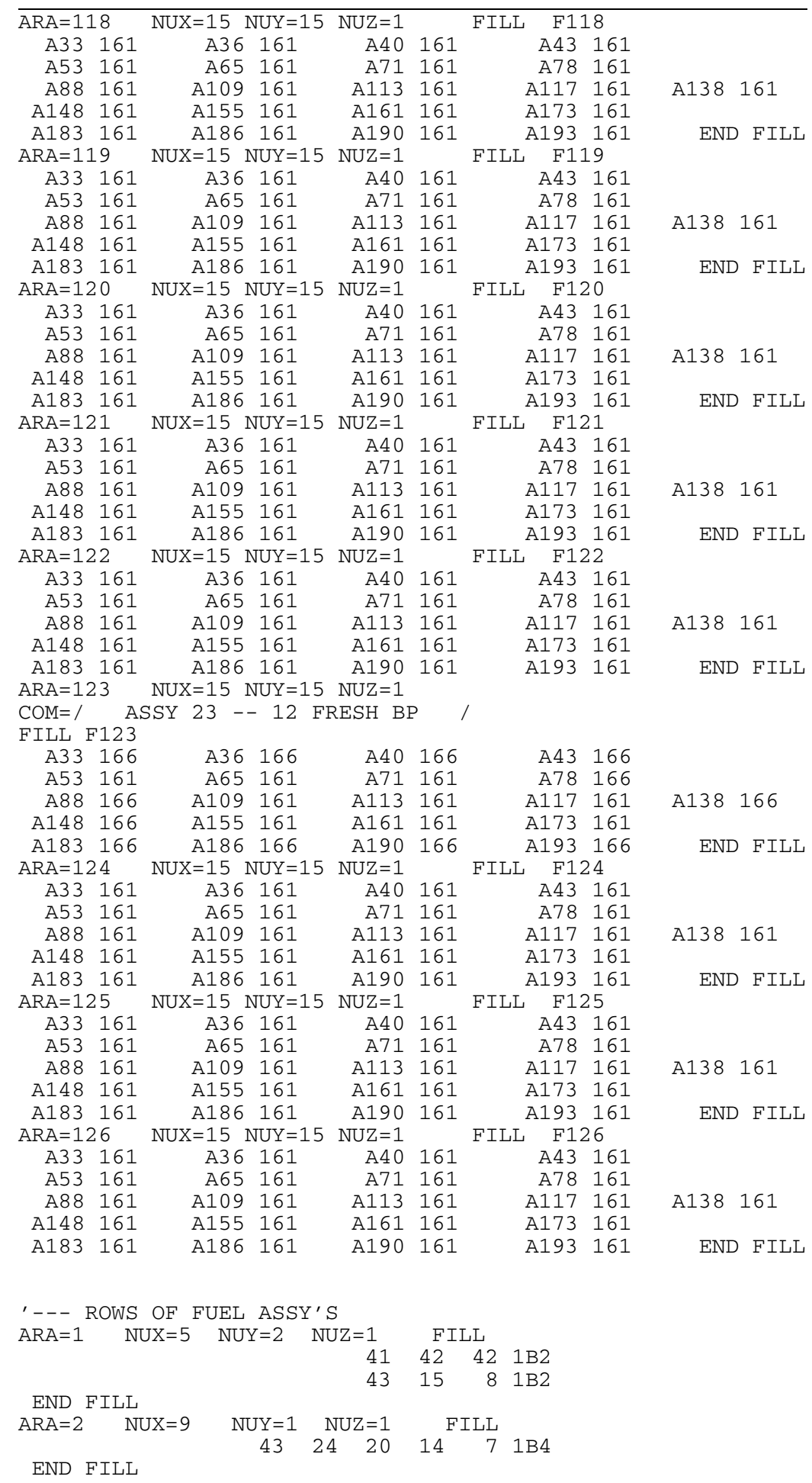


Table D.8. (continued)

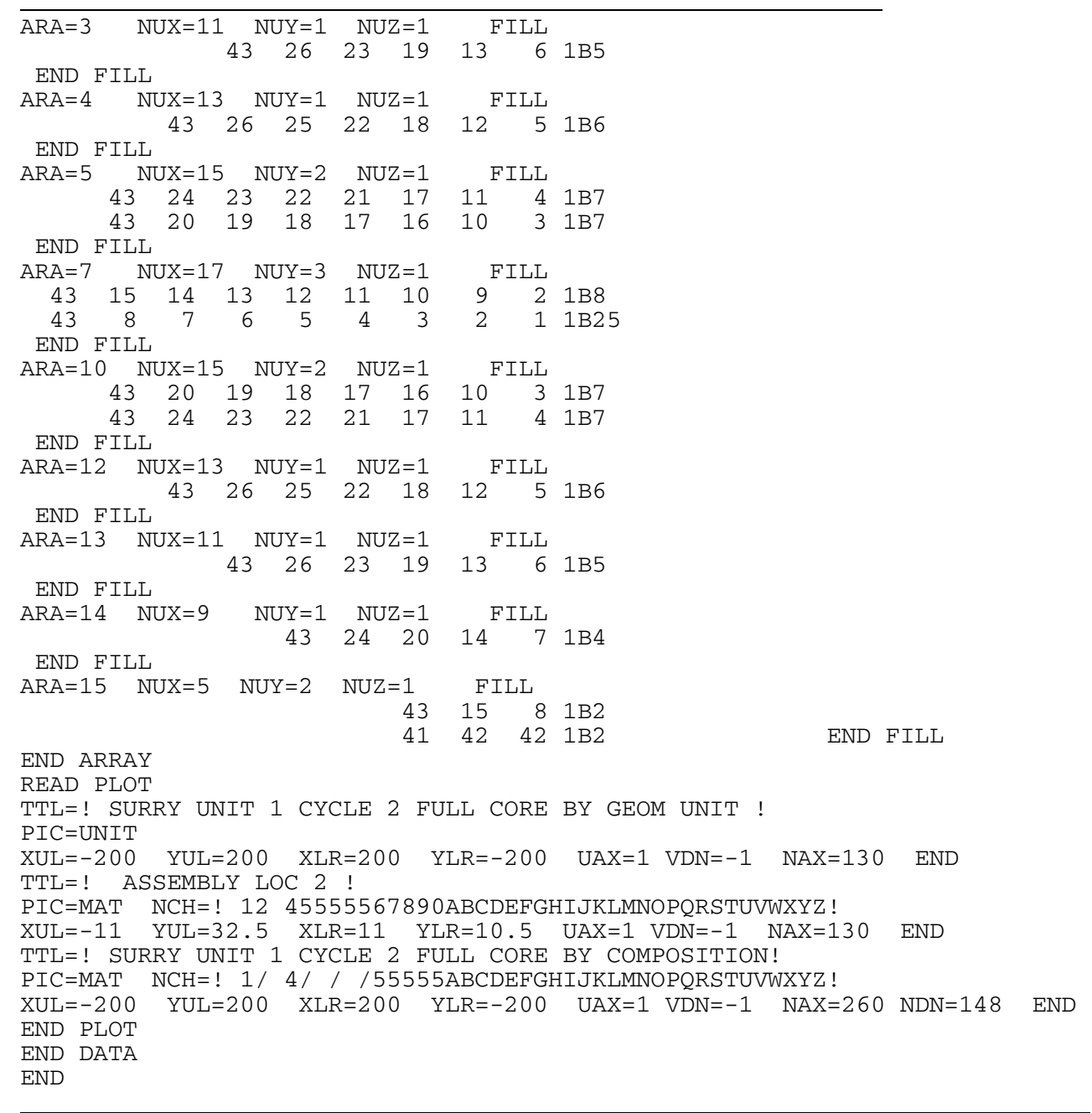




\section{APPENDIX E}

\section{KENO V.a EOC MODEL SETUP INPUT EXAMPLES}

This appendix gives examples of the input for the different calculational steps for setting up the Surry Unit 1 Cycle 2 KENO V.a models for EOC (HFP). 
Table E.1. SNIKR/ORIGEN-S input for fuel assembly isotopics

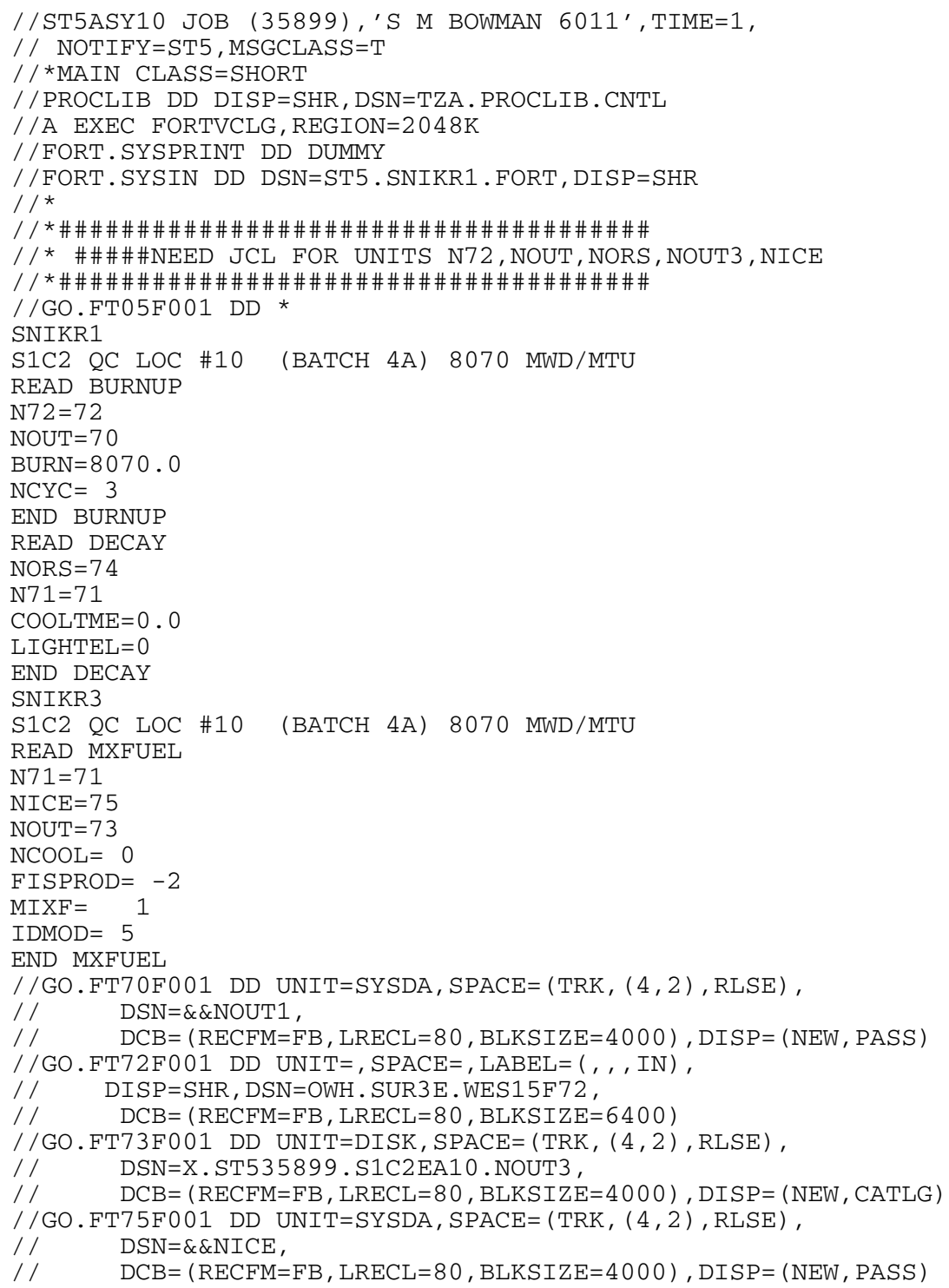


Table E.2. SNIKR/ORIGEN-S input for BP isotopics

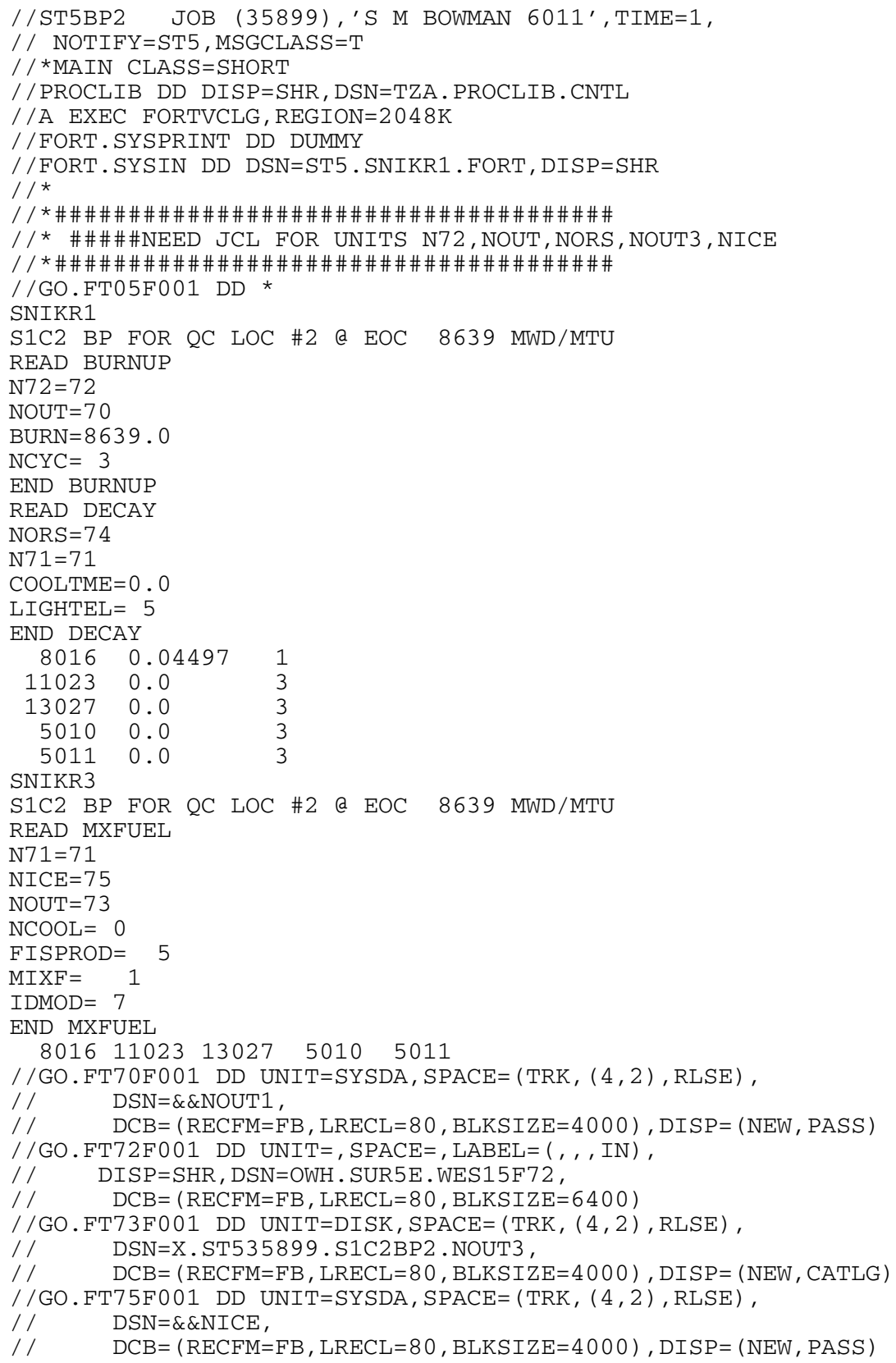


Table E.3. CSASN input for cross-section sets with important actinides only

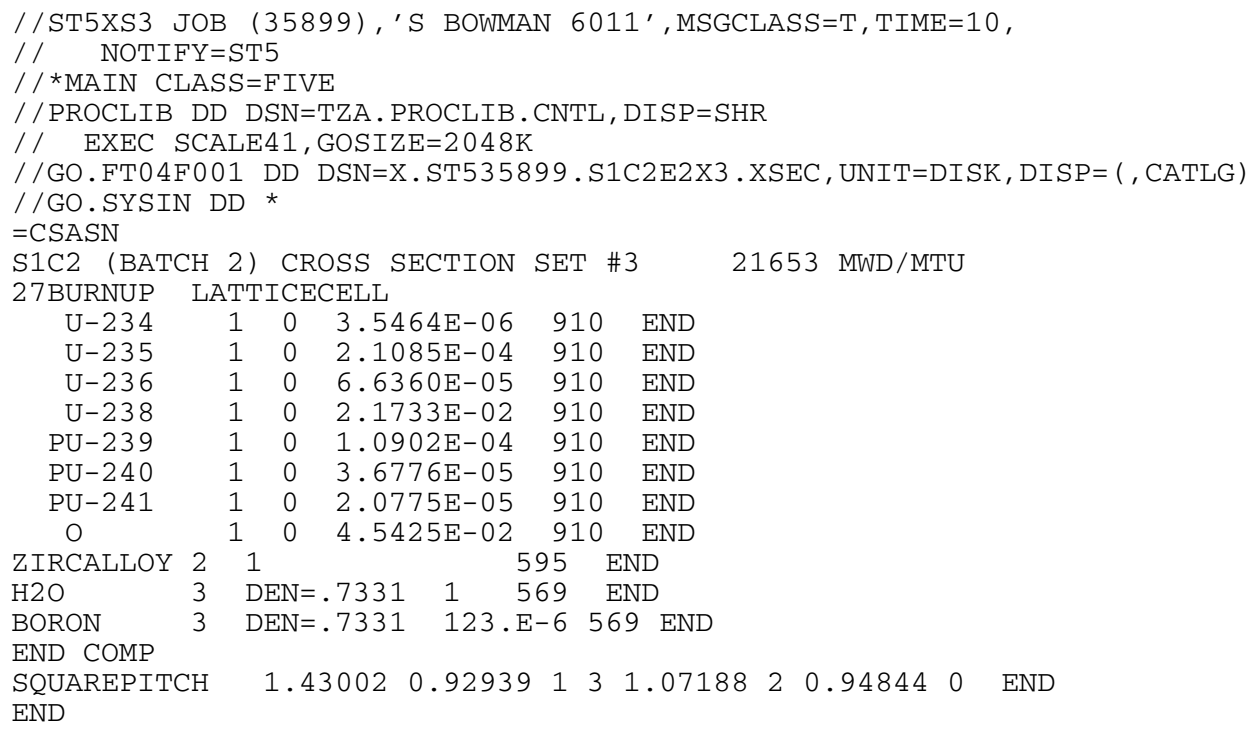


134

Table E.4. CSASN input for cross-section set 4

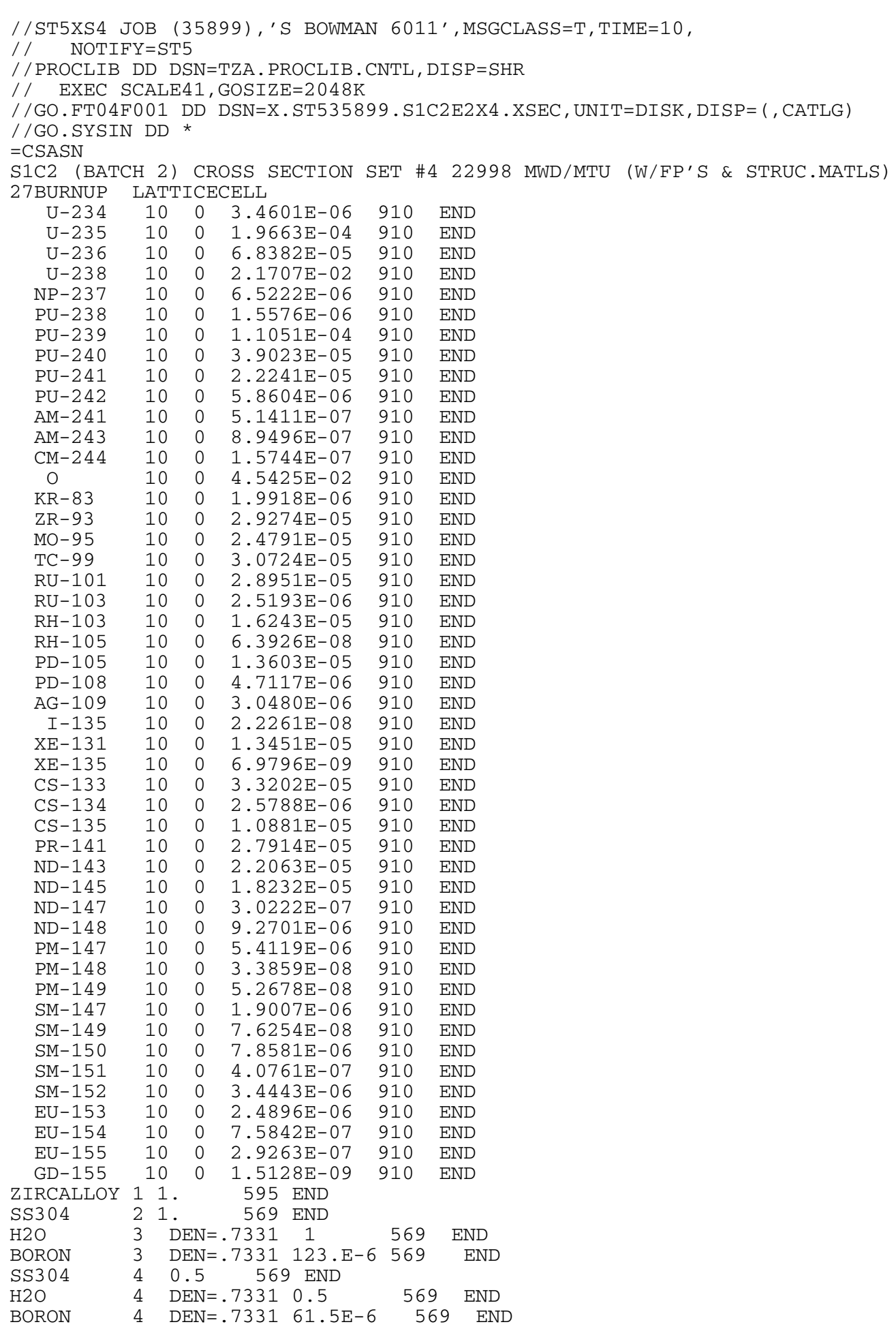


Table E.4. (continued)

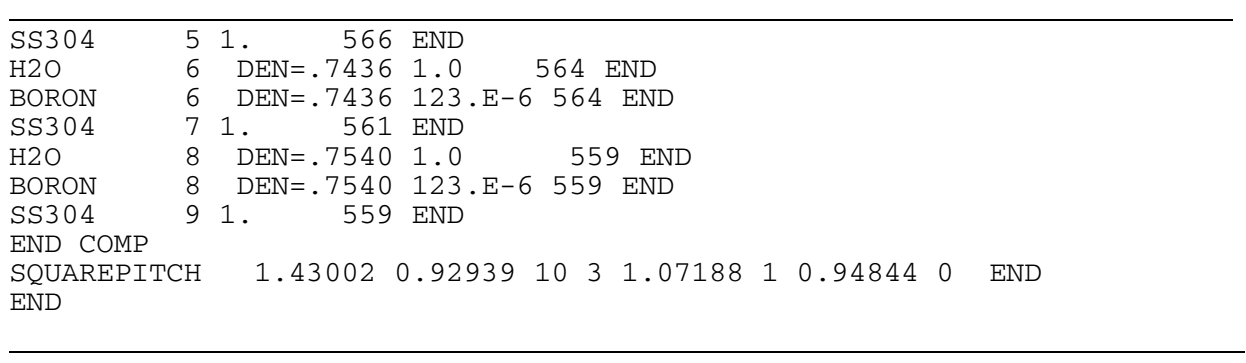


Table E.5. WAX input for cross-section library generation

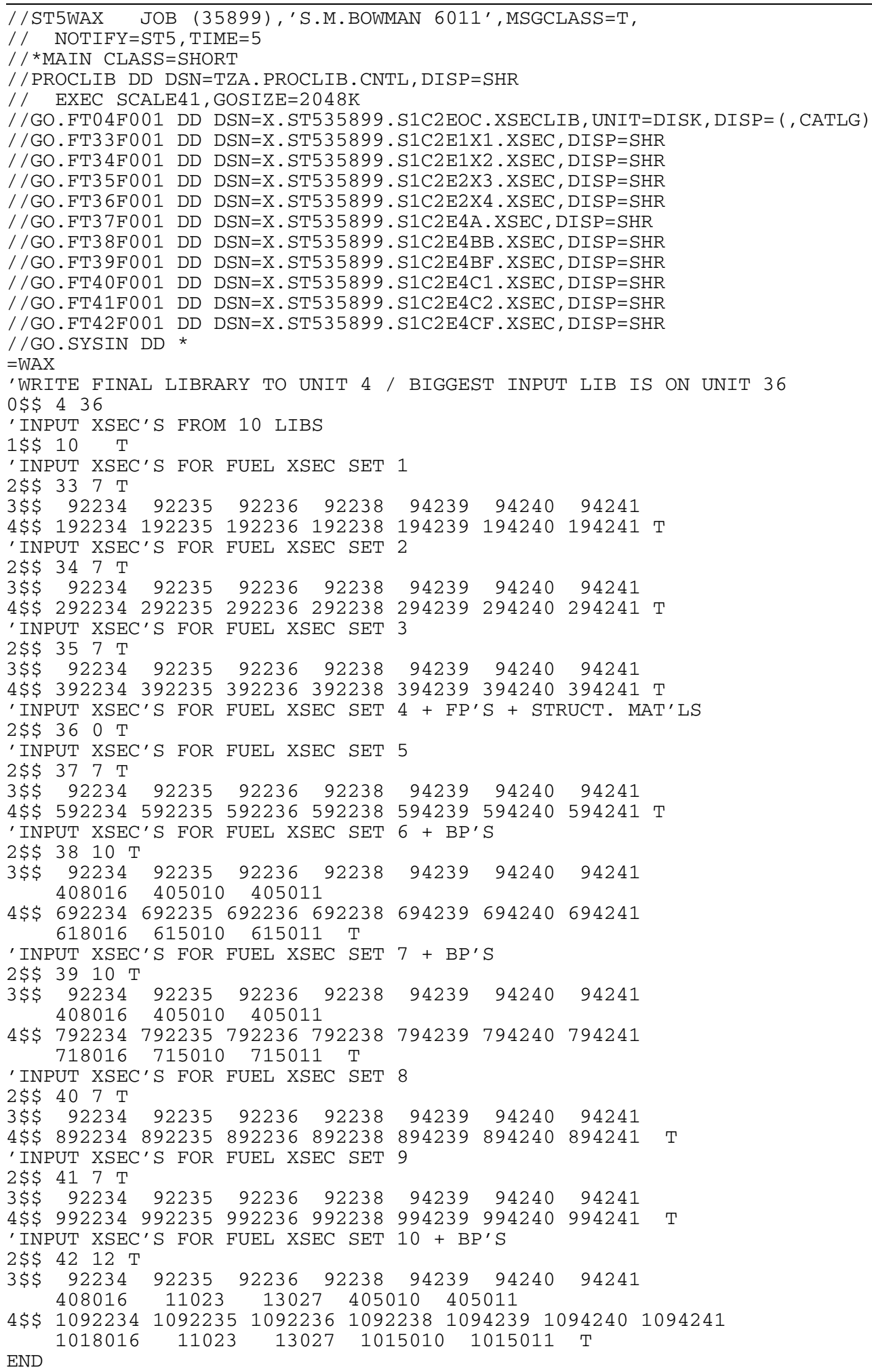


Table E.6. XSDRNPM input for eighth-core assembly location 9

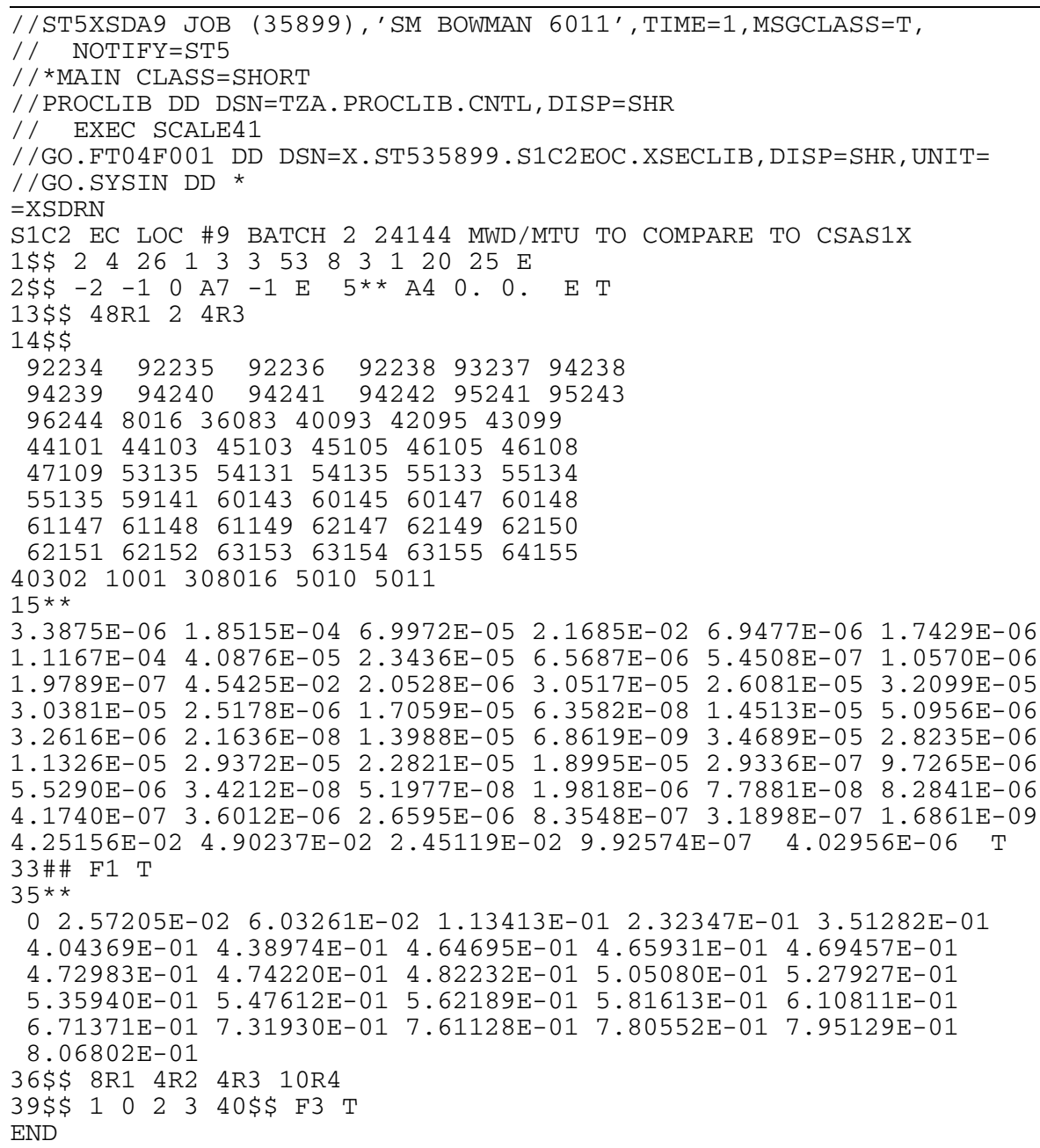


138

Table E.7. CSAS1X input for eighth-core assembly location 9

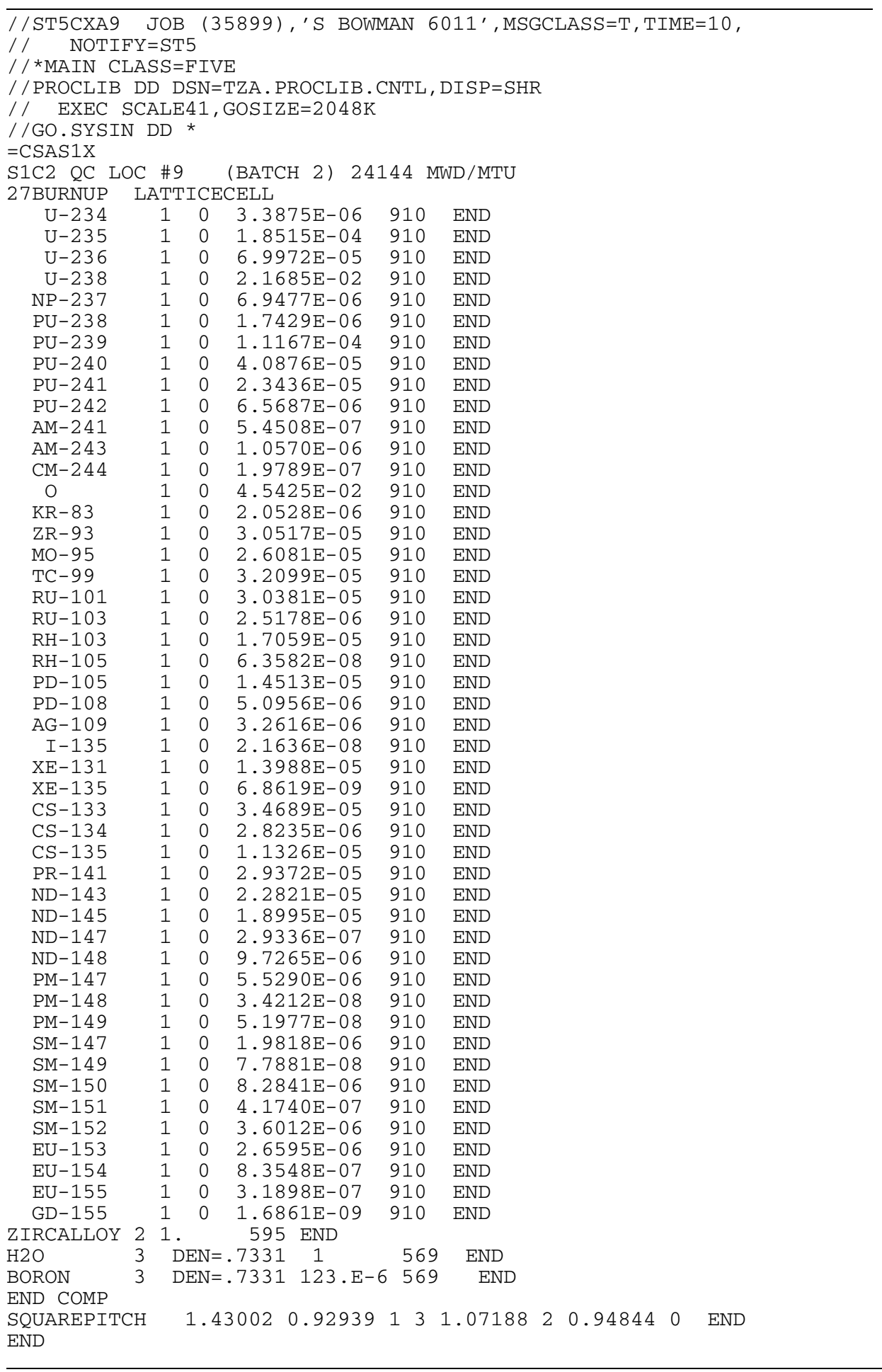


Table E.8. KENO V.a input file for EOC, HFP

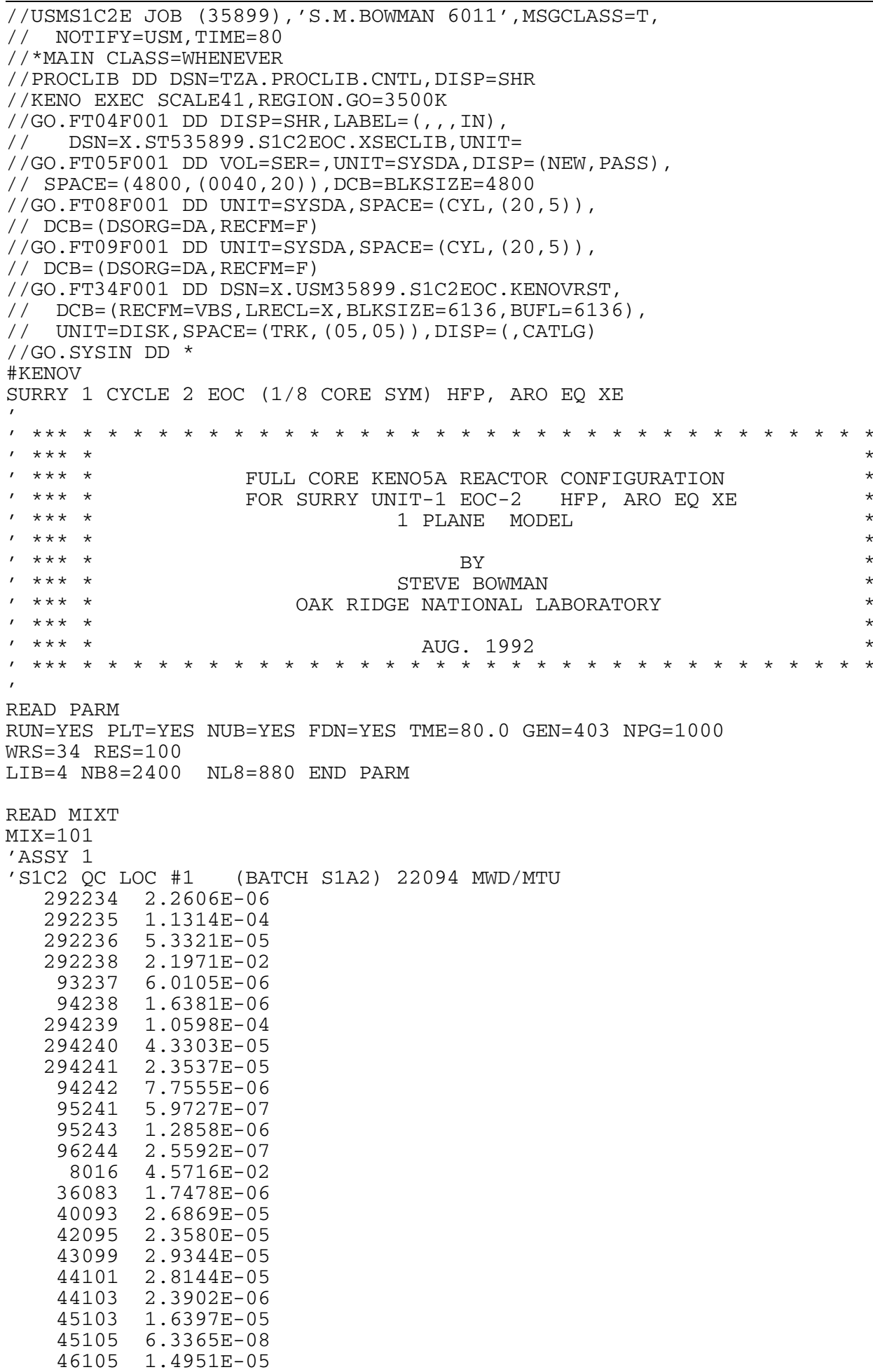


140

Table E.8. (continued)

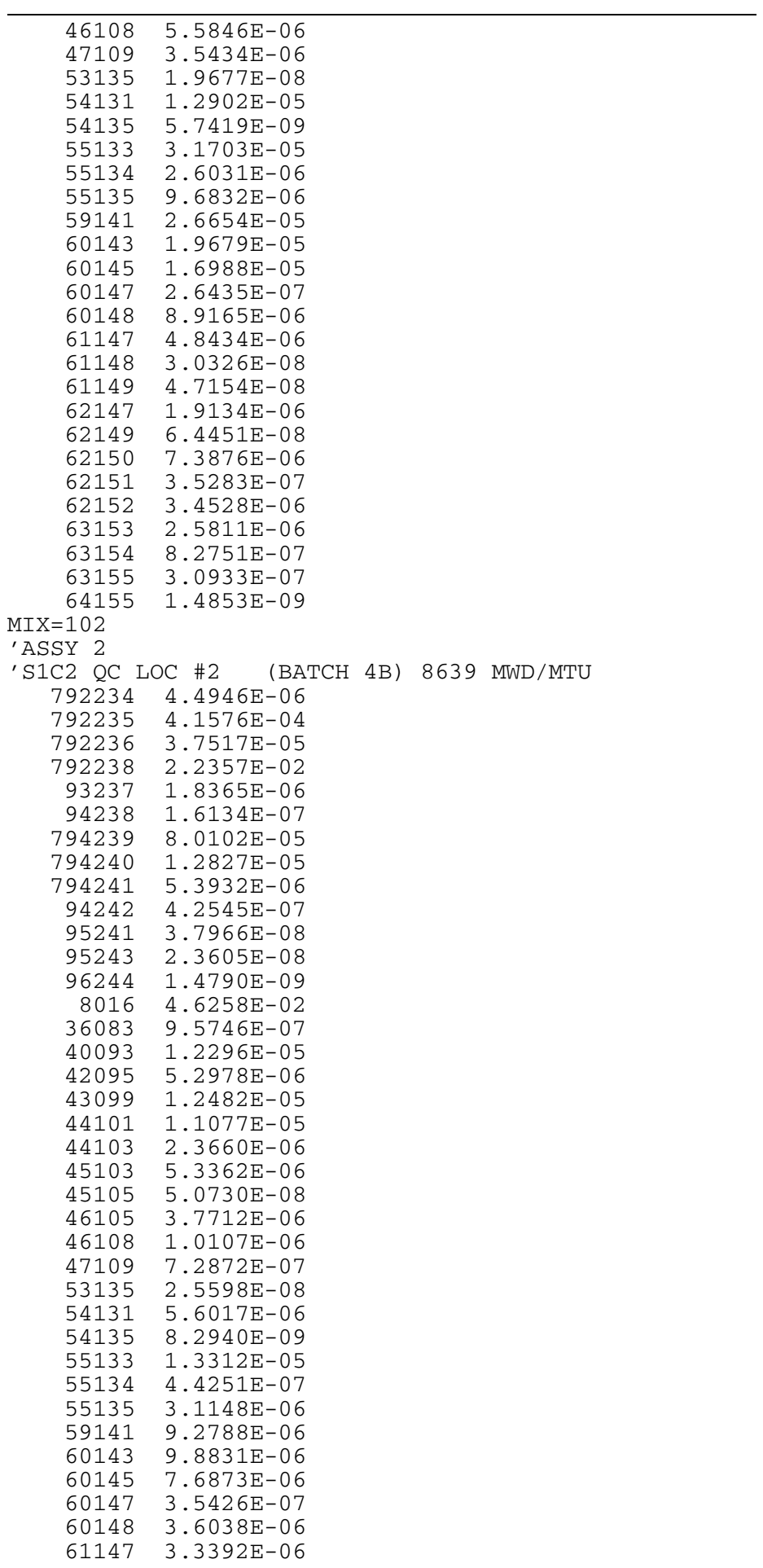


141

Table E.8. (continued)

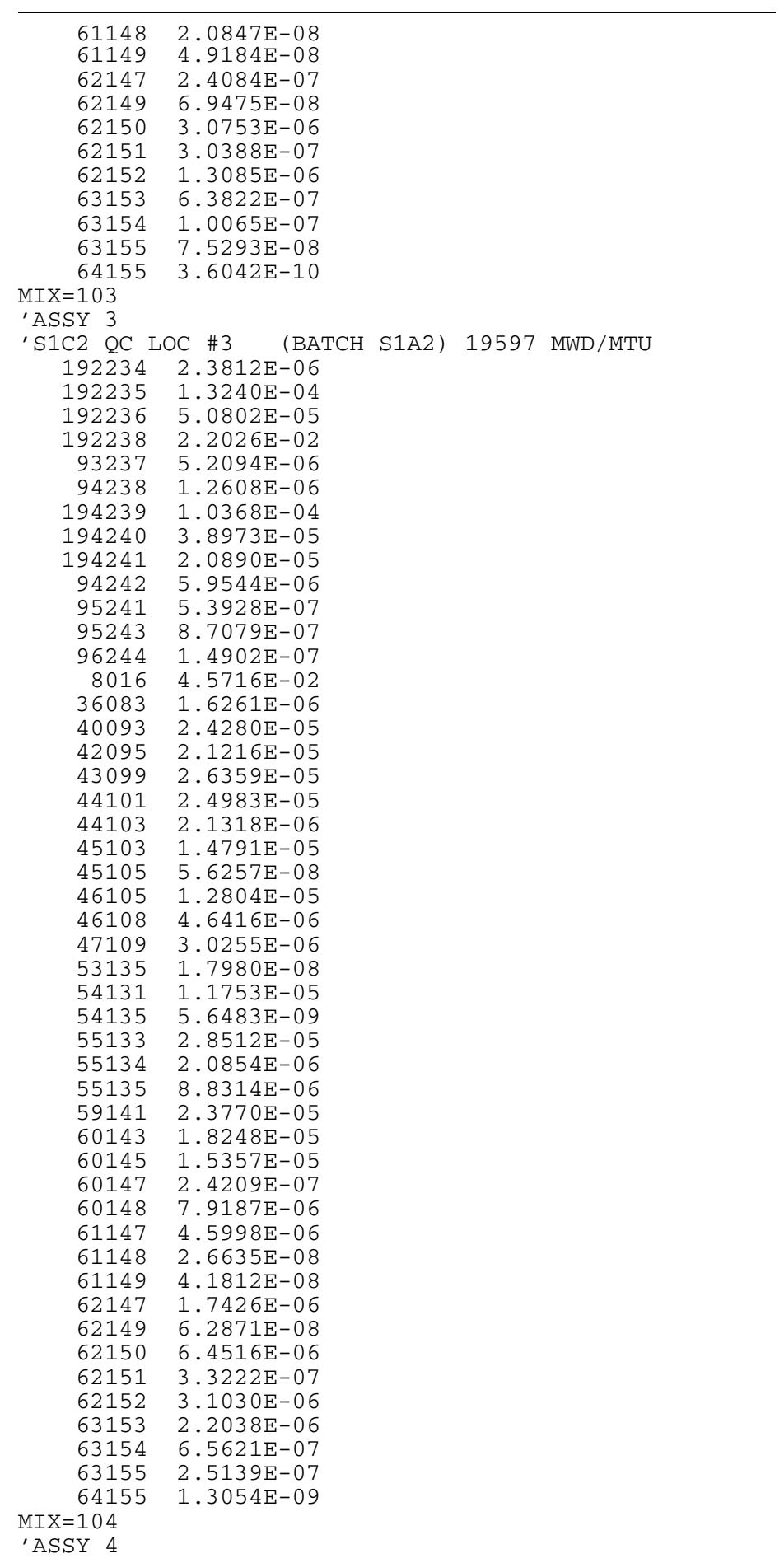


142

Table E.8. (continued)

\begin{tabular}{|c|c|c|c|}
\hline S1C2 QC & $\mathrm{HOC} \# 4 \quad(\mathrm{BATCH} \quad 4 \mathrm{~B})$ & 8373 & MWD /MTU \\
\hline 792234 & $4.5144 \mathrm{E}-06$ & & \\
\hline 792235 & $4.2076 \mathrm{E}-04$ & & \\
\hline 792236 & $3.6657 \mathrm{E}-05$ & & \\
\hline 792238 & $2.2361 \mathrm{E}-02$ & & \\
\hline 93237 & $1.7598 \mathrm{E}-06$ & & \\
\hline 94238 & $1.4976 \mathrm{E}-07$ & & \\
\hline 794239 & $7.8594 \mathrm{E}-05$ & & \\
\hline 794240 & $1.2304 \mathrm{E}-05$ & & \\
\hline 794241 & $5.0927 \mathrm{E}-06$ & & \\
\hline 94242 & $3.8563 \mathrm{E}-07$ & & \\
\hline 95241 & $3.4623 \mathrm{E}-08$ & & \\
\hline 95243 & $2.0351 \mathrm{E}-08$ & & \\
\hline 96244 & $1.2004 \mathrm{E}-09$ & & \\
\hline 8016 & $4.6258 \mathrm{E}-02$ & & \\
\hline 36083 & $9.3192 \mathrm{E}-07$ & & \\
\hline 40093 & $1.1941 \mathrm{E}-05$ & & \\
\hline 42095 & $5.0063 \mathrm{E}-06$ & & \\
\hline 43099 & 1. $2104 \mathrm{E}-05$ & & \\
\hline 44101 & $1.0734 \mathrm{E}-05$ & & \\
\hline 44103 & $2.3414 \mathrm{E}-06$ & & \\
\hline 45103 & $5.1205 E-06$ & & \\
\hline 45105 & $5.0154 \mathrm{E}-08$ & & \\
\hline 46105 & $3.6224 \mathrm{E}-06$ & & \\
\hline 46108 & $9.6170 \mathrm{E}-07$ & & \\
\hline 47109 & $6.9425 \mathrm{E}-07$ & & \\
\hline 53135 & $2.5605 E-08$ & & \\
\hline 54131 & $5.4287 \mathrm{E}-06$ & & \\
\hline 54135 & $8.2976 \mathrm{E}-09$ & & \\
\hline 55133 & 1.2900E-05 & & \\
\hline 55134 & $4.1622 \mathrm{E}-07$ & & \\
\hline 55135 & $3.0176 \mathrm{E}-06$ & & \\
\hline 59141 & $8.9260 \mathrm{E}-06$ & & \\
\hline 60143 & $9.5825 \mathrm{E}-06$ & & \\
\hline 60145 & $7.4652 \mathrm{E}-06$ & & \\
\hline 60147 & $3.5455 \mathrm{E}-07$ & & \\
\hline 60148 & $3.4936 \mathrm{E}-06$ & & \\
\hline 61147 & $3.2552 \mathrm{E}-06$ & & \\
\hline 61148 & $2.0286 \mathrm{E}-08$ & & \\
\hline 61149 & $4.8819 \mathrm{E}-08$ & & \\
\hline 62147 & $2.2717 \mathrm{E}-07$ & & \\
\hline 62149 & $6.8975 \mathrm{E}-08$ & & \\
\hline 62150 & $2.9643 \mathrm{E}-06$ & & \\
\hline 62151 & $2.9966 \mathrm{E}-07$ & & \\
\hline 62152 & $1.2636 \mathrm{E}-06$ & & \\
\hline 63153 & $6.1067 \mathrm{E}-07$ & & \\
\hline 63154 & $9.4074 \mathrm{E}-08$ & & \\
\hline 63155 & $7.2607 \mathrm{E}-08$ & & \\
\hline 64155 & $3.4711 \mathrm{E}-10$ & & \\
\hline $\mathrm{MIX}=105$ & & & \\
\hline ASSY 5 & & & \\
\hline S1C2 QC & SOC \#5 (BATCH 2) & 22670 & MWD / MTU \\
\hline 92234 & $3.4811 \mathrm{E}-06$ & & \\
\hline 92235 & $2.0002 \mathrm{E}-04$ & & \\
\hline 92236 & $6.7905 \mathrm{E}-05$ & & \\
\hline 92238 & $2.1714 \mathrm{E}-02$ & & \\
\hline 93237 & $6.4015 \mathrm{E}-06$ & & \\
\hline 94238 & $1.5066 \mathrm{E}-06$ & & \\
\hline 94239 & $1.1016 \mathrm{E}-04$ & & \\
\hline 94240 & $3.8482 \mathrm{E}-05$ & & \\
\hline 94241 & $2.1889 \mathrm{E}-05$ & & \\
\hline 94242 & $5.6639 \mathrm{E}-06$ & & \\
\hline 95241 & $5.0550 \mathrm{E}-07$ & & \\
\hline 95243 & $8.5159 \mathrm{E}-07$ & & \\
\hline
\end{tabular}


143

Table E.8. (continued)

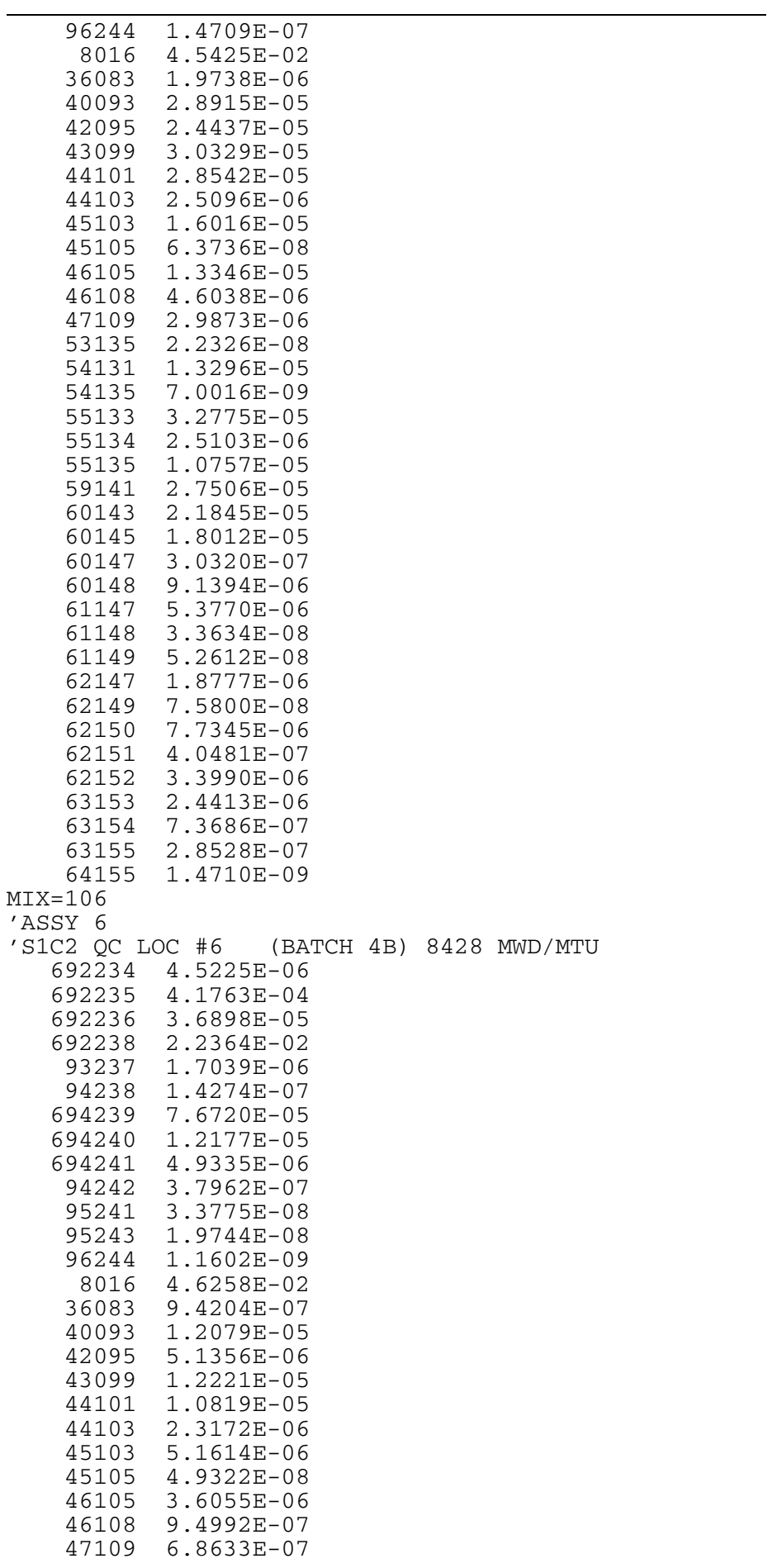


144

Table E.8. (continued)

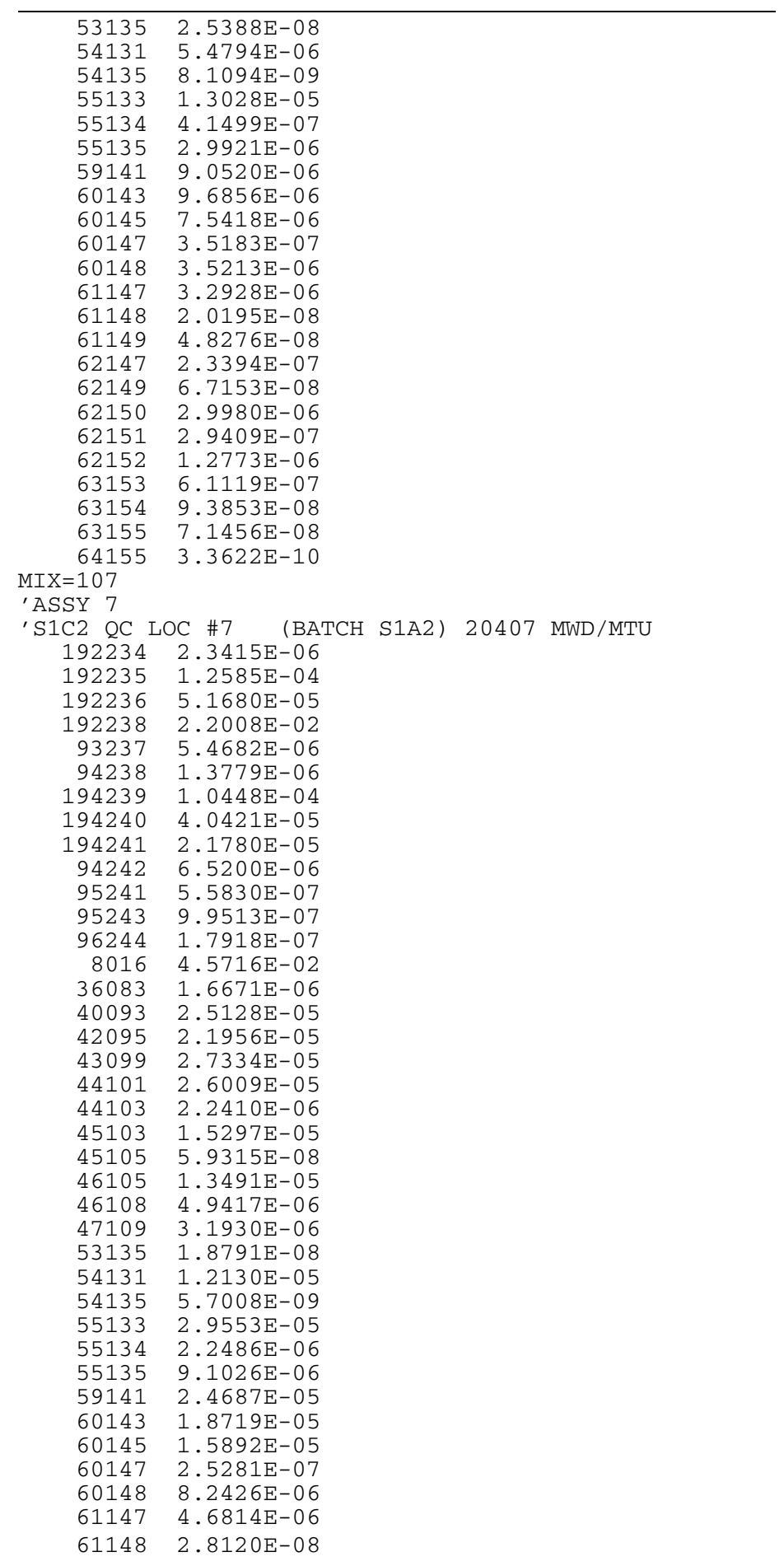


145

Table E.8. (continued)

\begin{tabular}{|c|c|c|}
\hline 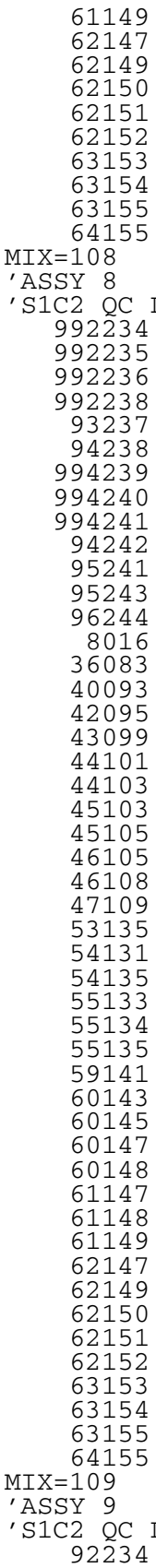 & 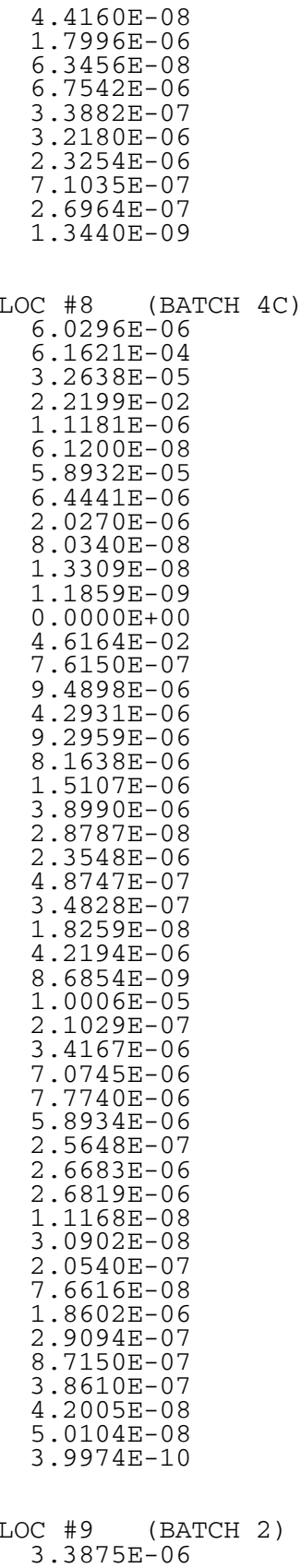 & 6398 MWD/MTU \\
\hline
\end{tabular}


146

Table E.8. (continued)

\begin{tabular}{|c|c|}
\hline $\begin{array}{c}92235 \\
92236 \\
92238 \\
93237 \\
94238 \\
94239 \\
94240 \\
94241 \\
94242 \\
95241 \\
95243 \\
96244 \\
8016 \\
36083 \\
40093 \\
42095 \\
43099 \\
44101 \\
44103 \\
45103 \\
45105 \\
46105 \\
46108 \\
47109 \\
53135 \\
54131 \\
54135 \\
55133 \\
55134 \\
55135 \\
59141 \\
60143 \\
60145 \\
60147 \\
60148 \\
61147 \\
61148 \\
61149 \\
62147 \\
62149 \\
62150 \\
62151 \\
62152 \\
63153 \\
63154 \\
63155 \\
64155 \\
\mathrm{~A} S \mathrm{~S} 110 \\
520 \\
592234 \\
592235 \\
592236 \\
592238 \\
93237 \\
94238 \\
594239 \\
594240 \\
594241 \\
94242 \\
95241 \\
95243 \\
96244 \\
8016\end{array}$ & 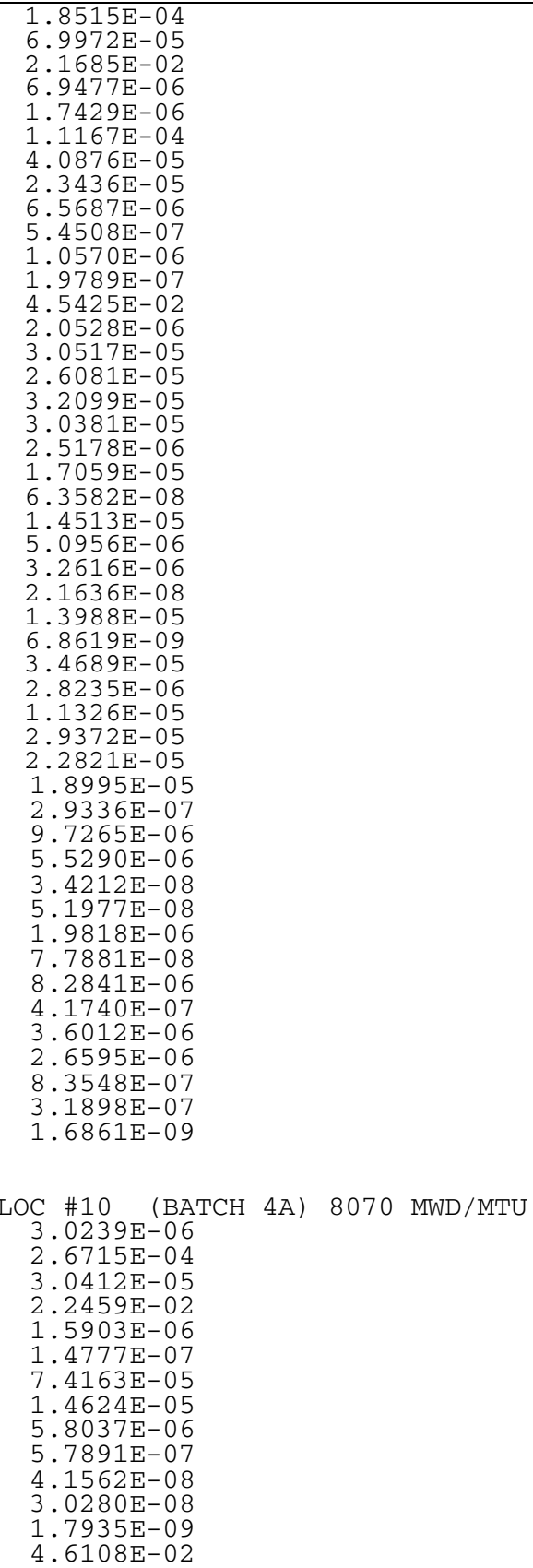 \\
\hline
\end{tabular}


147

Table E.8. (continued)

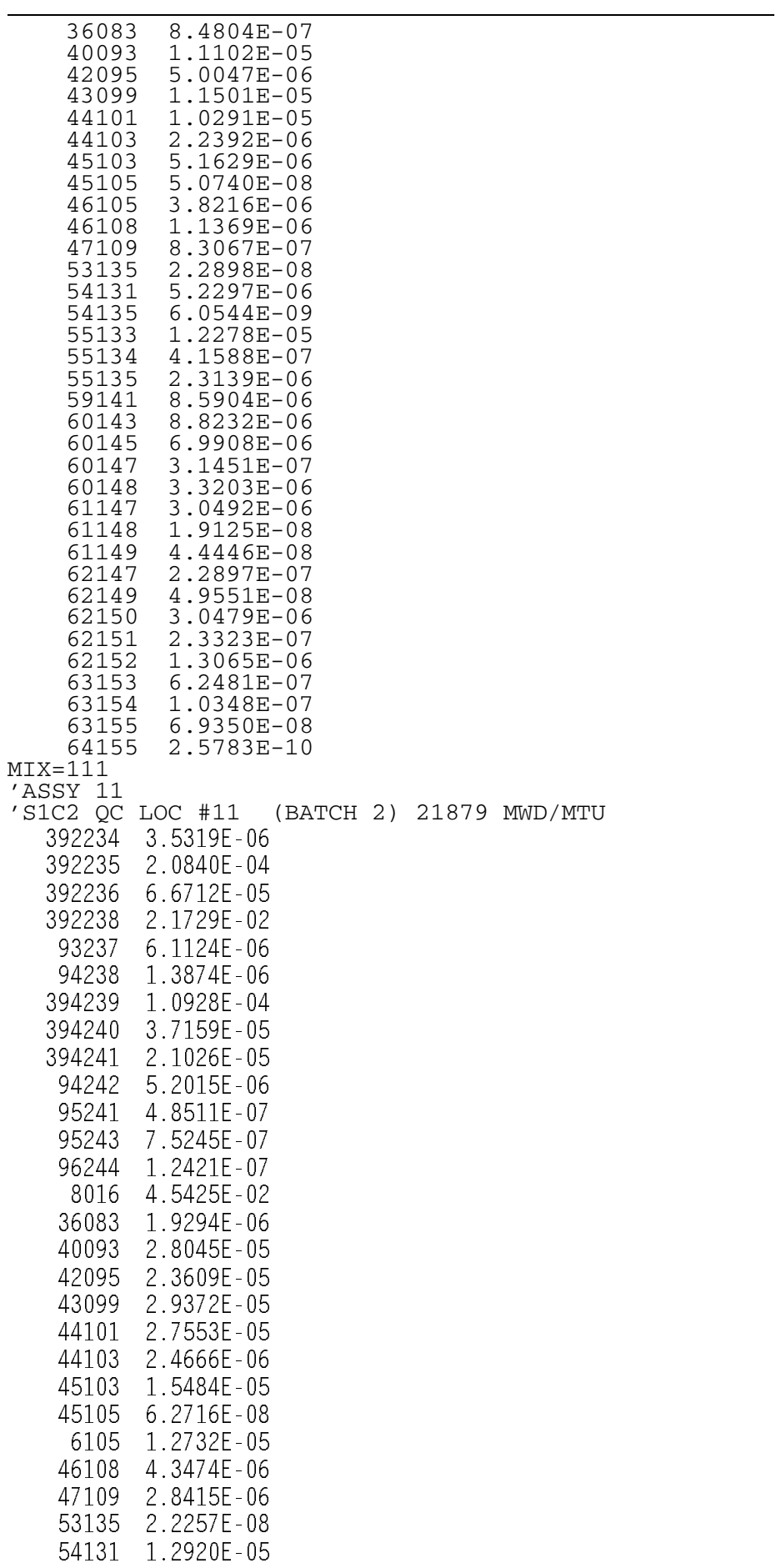


148

Table E.8. (continued)

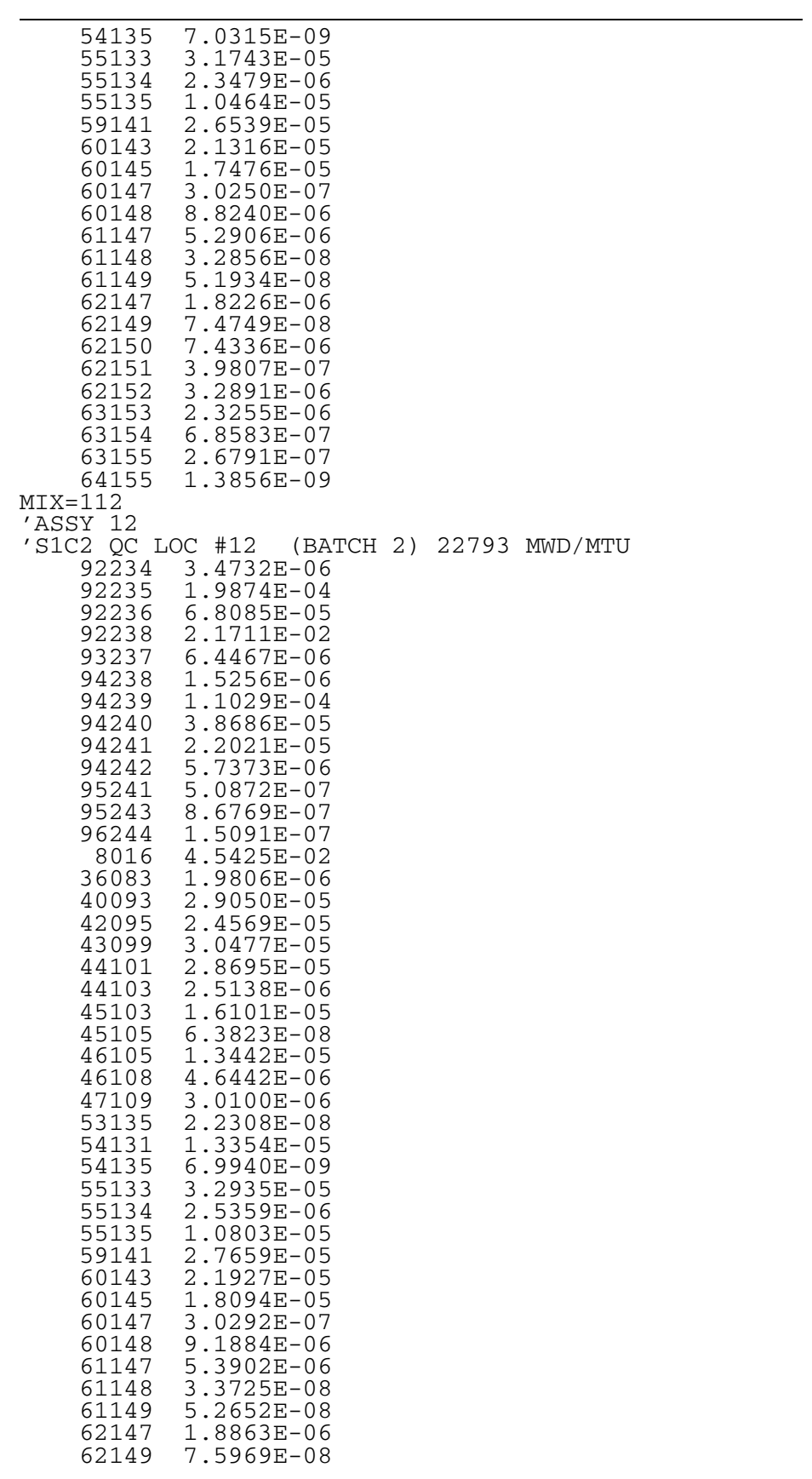


149

Table E.8. (continued)

\begin{tabular}{|c|c|c|}
\hline 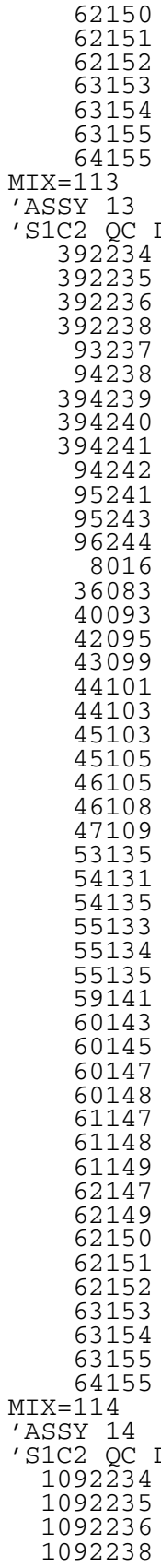 & $\begin{array}{l}7.7809 \mathrm{E}-06 \\
4.0586 \mathrm{E}-07 \\
3.4160 \mathrm{E}-06 \\
2.4594 \mathrm{E}-06 \\
7.4492 \mathrm{E}-07 \\
2.8803 \mathrm{E}-07 \\
1.4862 \mathrm{E}-09 \\
\\
\text { OC } \# 13 \quad(\mathrm{BATCH} \quad 2) \\
3.5611 \mathrm{E}-06 \\
2.1332 \mathrm{E}-04 \\
6.6004 \mathrm{E}-05 \\
2.1738 \mathrm{E}-02 \\
5.9487 \mathrm{E}-06 \\
1.3218 \mathrm{E}-06 \\
1.0875 \mathrm{E}-04 \\
3.6391 \mathrm{E}-05 \\
2.0523 \mathrm{E}-05 \\
4.9449 \mathrm{E}-06 \\
4.7364 \mathrm{E}-07 \\
6.9922 \mathrm{E}-07 \\
1.1240 \mathrm{E}-07 \\
4.5425 \mathrm{E}-02 \\
1.9034 \mathrm{E}-06 \\
2.7545 \mathrm{E}-05 \\
2.3152 \mathrm{E}-05 \\
2.8823 \mathrm{E}-05 \\
2.6987 \mathrm{E}-05 \\
2.4299 \mathrm{E}-06 \\
1.5188 \mathrm{E}-05 \\
6.1779 \mathrm{E}-08 \\
1.2385 \mathrm{E}-05 \\
4.2032 \mathrm{E}-06 \\
2.7588 \mathrm{E}-06 \\
2.2075 \mathrm{E}-08 \\
1.2705 \mathrm{E}-05 \\
7.0340 \mathrm{E}-09 \\
3.1151 \mathrm{E}-05 \\
2.2570 \mathrm{E}-06 \\
1.0300 \mathrm{E}-05 \\
2.5997 \mathrm{E}-05 \\
2.1012 \mathrm{E}-05 \\
1.7167 \mathrm{E}-05 \\
3.0016 \mathrm{E}-07 \\
8.6437 \mathrm{E}-06 \\
5.2399 \mathrm{E}-06 \\
3.2263 \mathrm{E}-08 \\
5.1219 \mathrm{E}-08 \\
1.7910 \mathrm{E}-06 \\
7.4186 \mathrm{E}-08 \\
7.2598 \mathrm{E}-06 \\
3.9423 \mathrm{E}-07 \\
3.2259 \mathrm{E}-06 \\
2.2598 \mathrm{E}-06 \\
6.5730 \mathrm{E}-07 \\
2.5822 \mathrm{E}-07 \\
1.3463 \mathrm{E}-09 \\
\\
\\
\text { OC } \# 14 \quad(\mathrm{BATCH} \quad 4 \mathrm{C}) \\
5.9717 \mathrm{E}-06 \\
6.1813 \mathrm{E}-04 \\
3.3318 \mathrm{E}-05 \\
2.2186 \mathrm{E}-02 \\
\end{array}$ & 21427 MWD/MTU \\
\hline
\end{tabular}


150

Table E.8. (continued)

\begin{tabular}{|c|c|}
\hline $\begin{array}{c}93237 \\
94238 \\
1094239 \\
1094240 \\
1094241 \\
94242 \\
95241 \\
95243 \\
96244 \\
8016 \\
36083 \\
40093 \\
42095 \\
43099 \\
44101 \\
44103 \\
45103 \\
45105 \\
46105 \\
46108 \\
47109 \\
53135 \\
54131 \\
54135 \\
55133 \\
55134 \\
55135 \\
59141 \\
60143 \\
60145 \\
60147 \\
60148 \\
61147 \\
61148 \\
61149 \\
62147 \\
62149 \\
62150 \\
62151 \\
62152 \\
63153 \\
63154 \\
63155 \\
64155 \\
\mathrm{M} I \mathrm{~A} S \mathrm{SY} \\
\mathrm{S} 115 \\
8920 \mathrm{1} \\
892 \mathrm{C} \\
892235 \\
892236 \\
892238 \\
93237 \\
94238 \\
894239 \\
894240 \\
894241 \\
94242 \\
95241 \\
95243 \\
96244 \\
8016 \\
36083 \\
40093 \\
42095 \\
43099\end{array}$ & $\begin{array}{l}1.3067 \mathrm{E}-06 \\
7.8765 \mathrm{E}-08 \\
6.7521 \mathrm{E}-05 \\
7.1809 \mathrm{E}-06 \\
2.5684 \mathrm{E}-06 \\
1.0245 \mathrm{E}-07 \\
1.5312 \mathrm{E}-08 \\
2.3148 \mathrm{E}-09 \\
0.0000 \mathrm{E}+00 \\
4.6164 \mathrm{E}-02 \\
7.6015 \mathrm{E}-07 \\
9.4814 \mathrm{E}-06 \\
3.8262 \mathrm{E}-06 \\
9.3228 \mathrm{E}-06 \\
8.2520 \mathrm{E}-06 \\
1.7426 \mathrm{E}-06 \\
3.8259 \mathrm{E}-06 \\
3.4810 \mathrm{E}-08 \\
2.4865 \mathrm{E}-06 \\
5.4447 \mathrm{E}-07 \\
3.8888 \mathrm{E}-07 \\
2.0965 \mathrm{E}-08 \\
4.2113 \mathrm{E}-06 \\
9.7820 \mathrm{E}-09 \\
1.0013 \mathrm{E}-05 \\
2.3956 \mathrm{E}-07 \\
3.3583 \mathrm{E}-06 \\
6.8743 \mathrm{E}-06 \\
7.6995 \mathrm{E}-06 \\
5.9055 \mathrm{E}-06 \\
2.9315 \mathrm{E}-07 \\
2.6996 \mathrm{E}-06 \\
2.6545 \mathrm{E}-06 \\
1.3416 \mathrm{E}-08 \\
3.6635 \mathrm{E}-08 \\
1.7682 \mathrm{E}-07 \\
8.6470 \mathrm{E}-08 \\
1.9258 \mathrm{E}-06 \\
3.1399 \mathrm{E}-07 \\
8.6999 \mathrm{E}-07 \\
4.0652 \mathrm{E}-07 \\
4.7572 \mathrm{E}-08 \\
5.5139 \mathrm{E}-08 \\
4.1977 \mathrm{E}-10 \\
\\
6\end{array}$ \\
\hline
\end{tabular}


151

Table E.8. (continued)

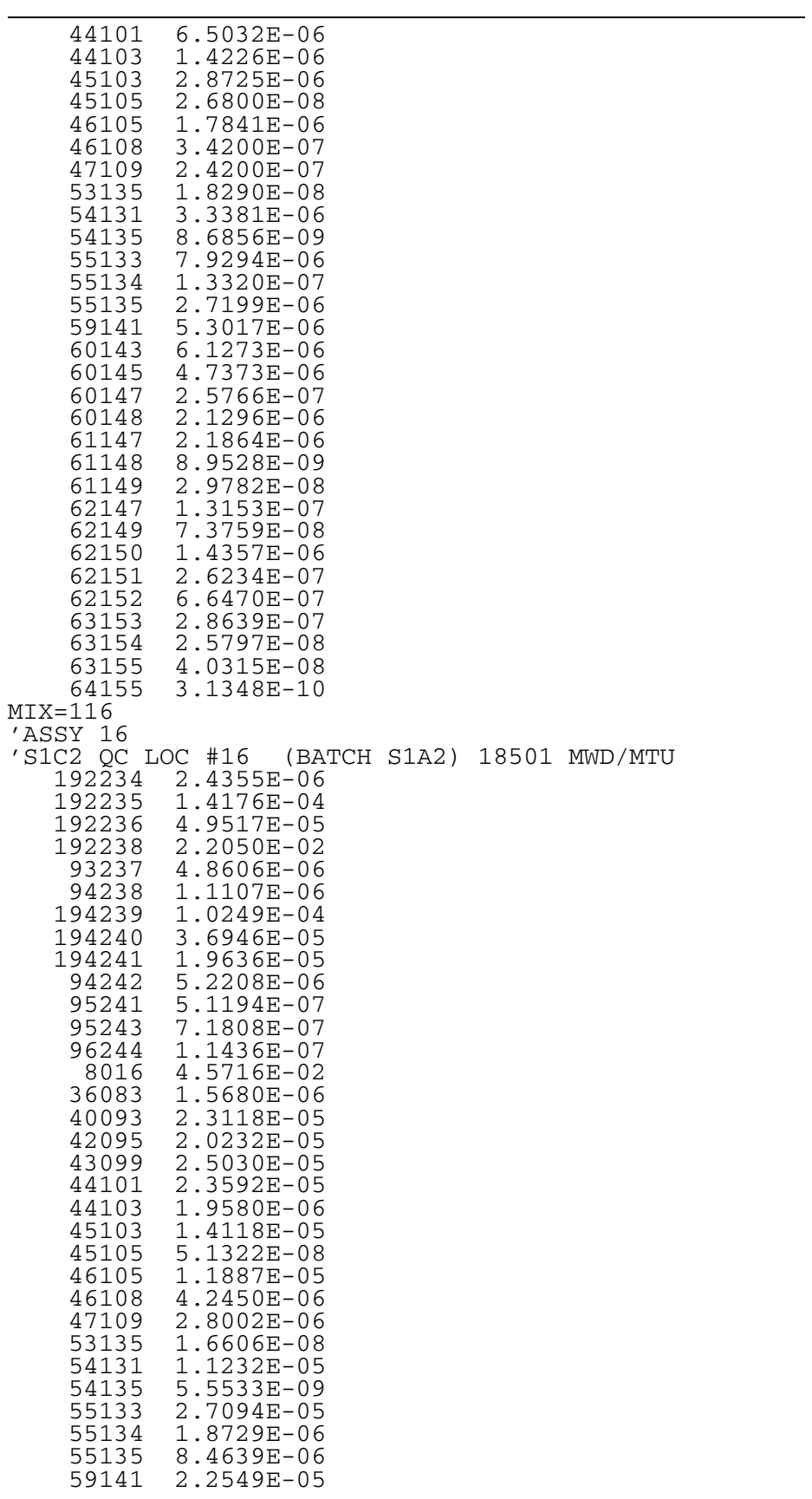


152

Table E.8. (continued)

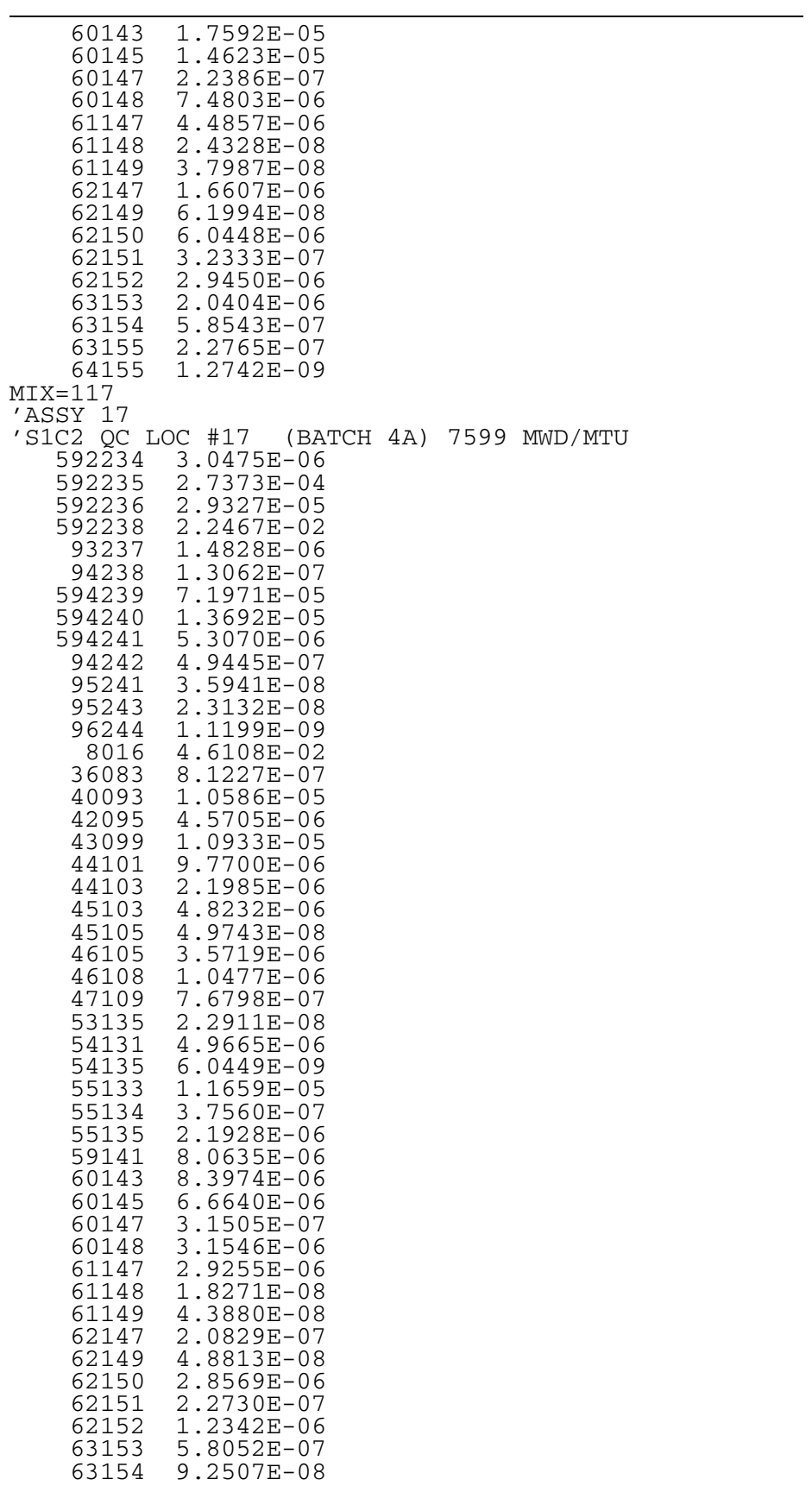


153

Table E.8. (continued)

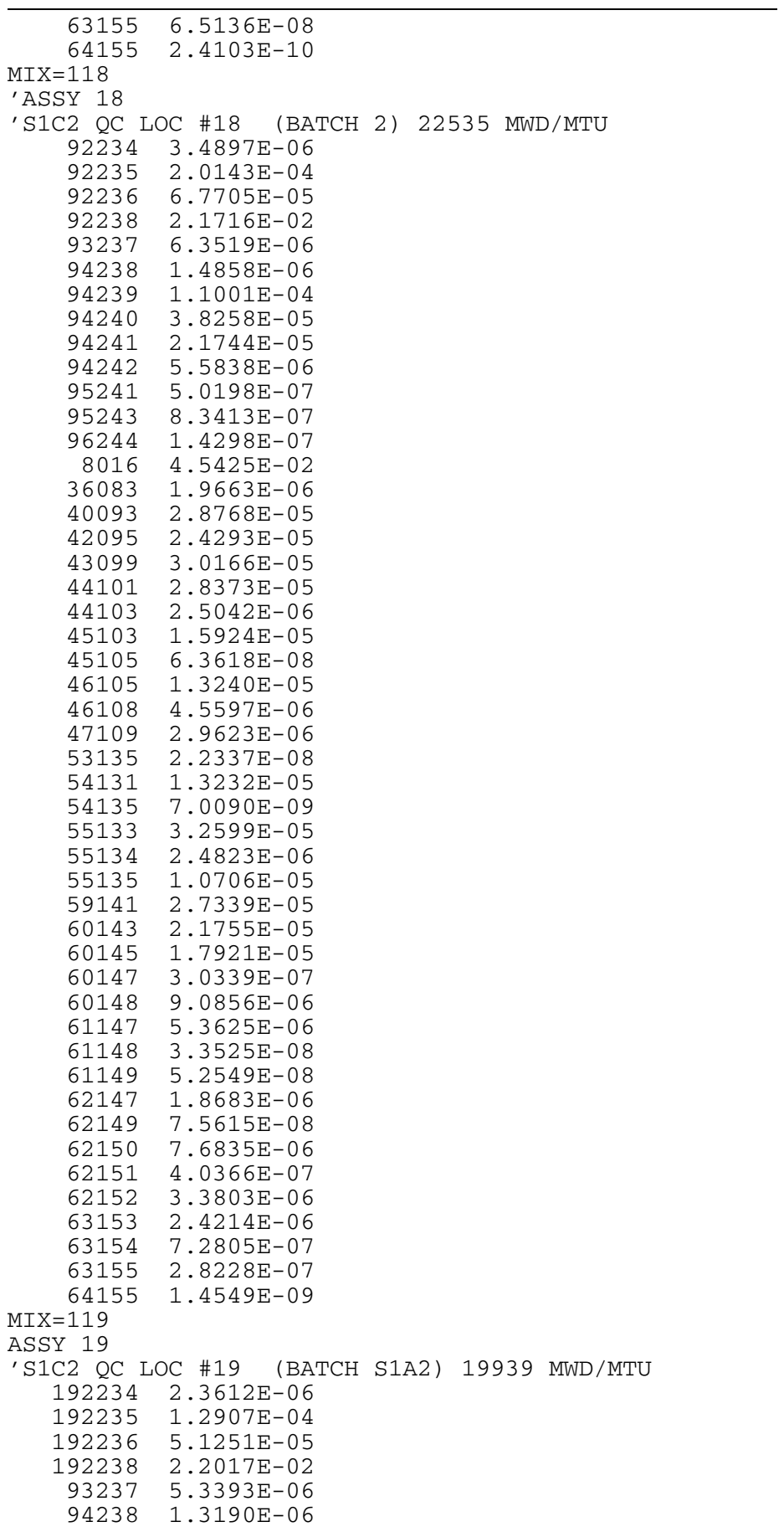




\section{4}

Table E.8. (continued)

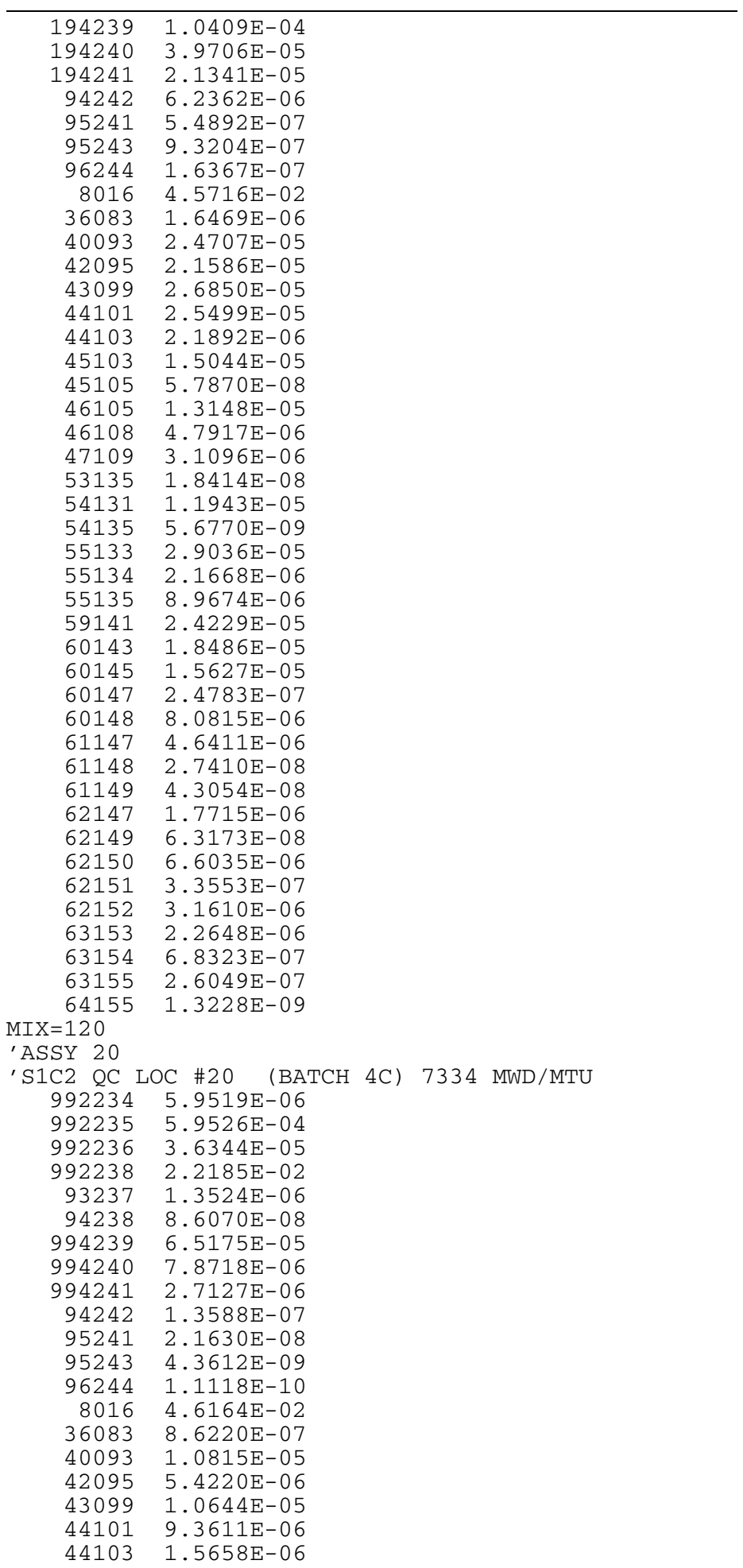


155

Table E.8. (continued)

\begin{tabular}{|c|c|}
\hline 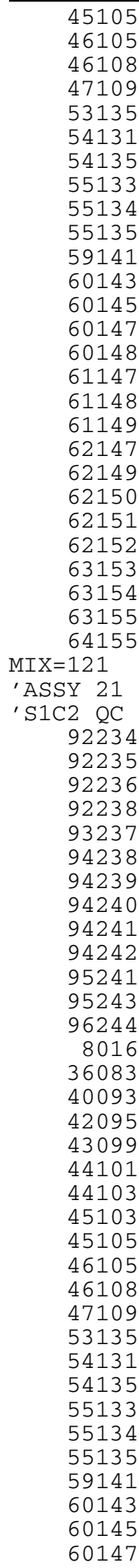 & 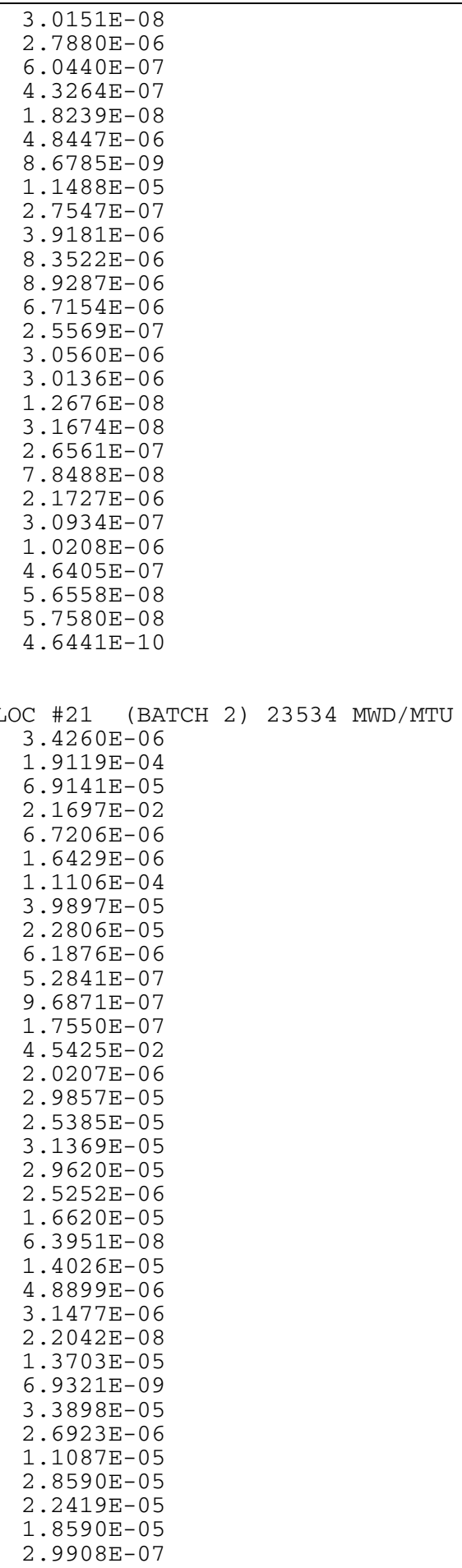 \\
\hline
\end{tabular}


156

Table E.8. (continued)

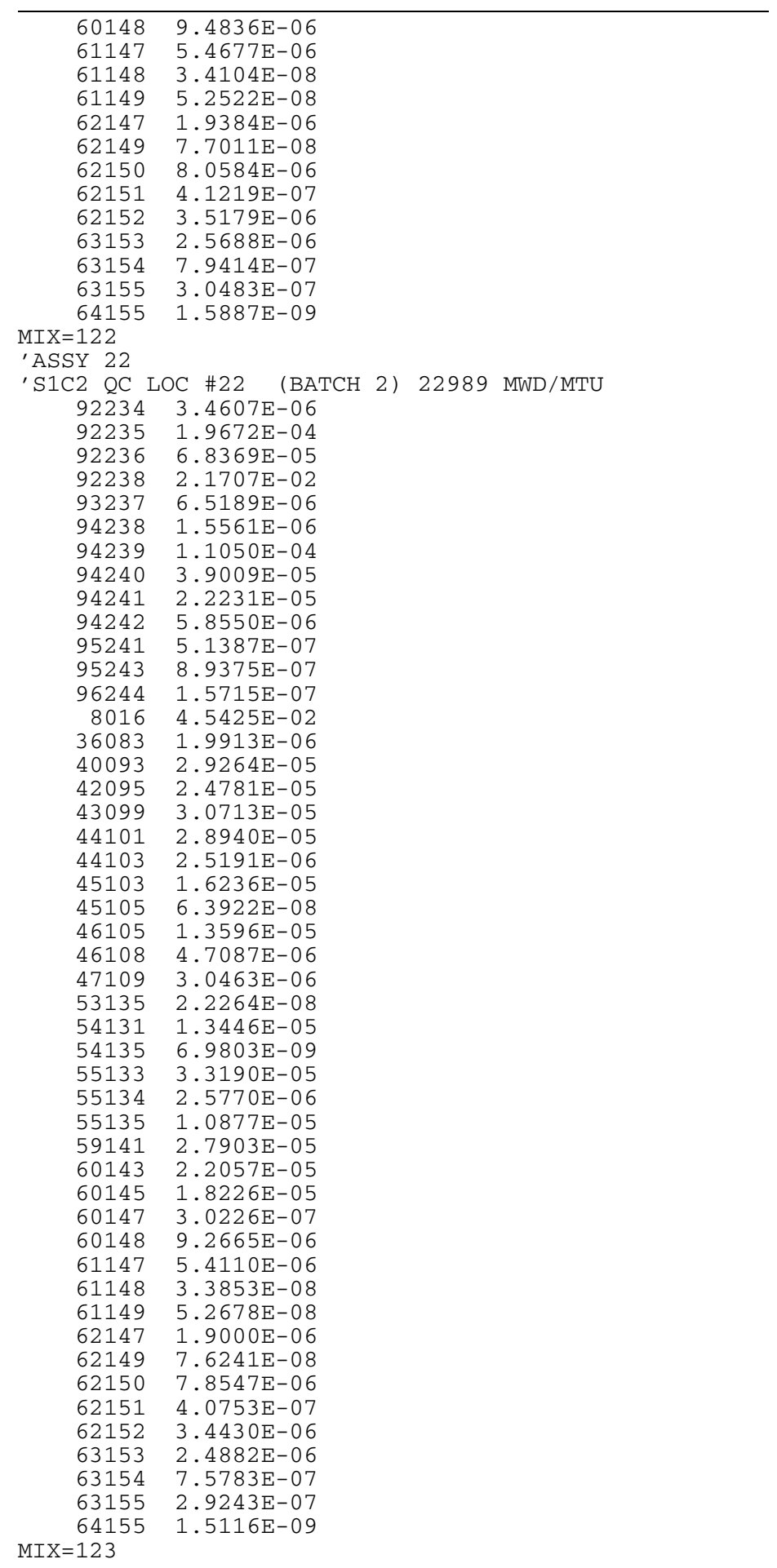


Table E.8. (continued)

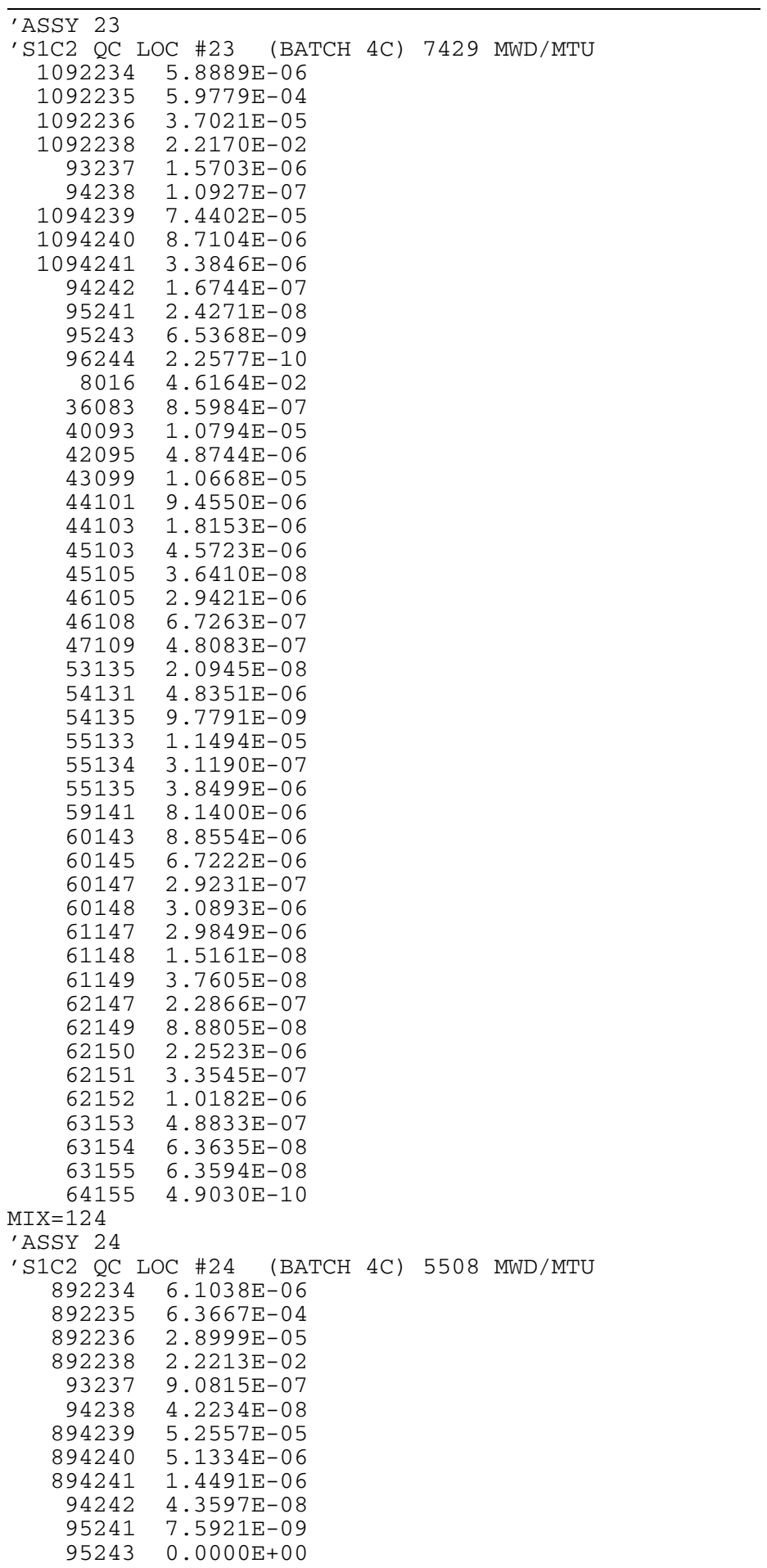


158

Table E.8. (continued)

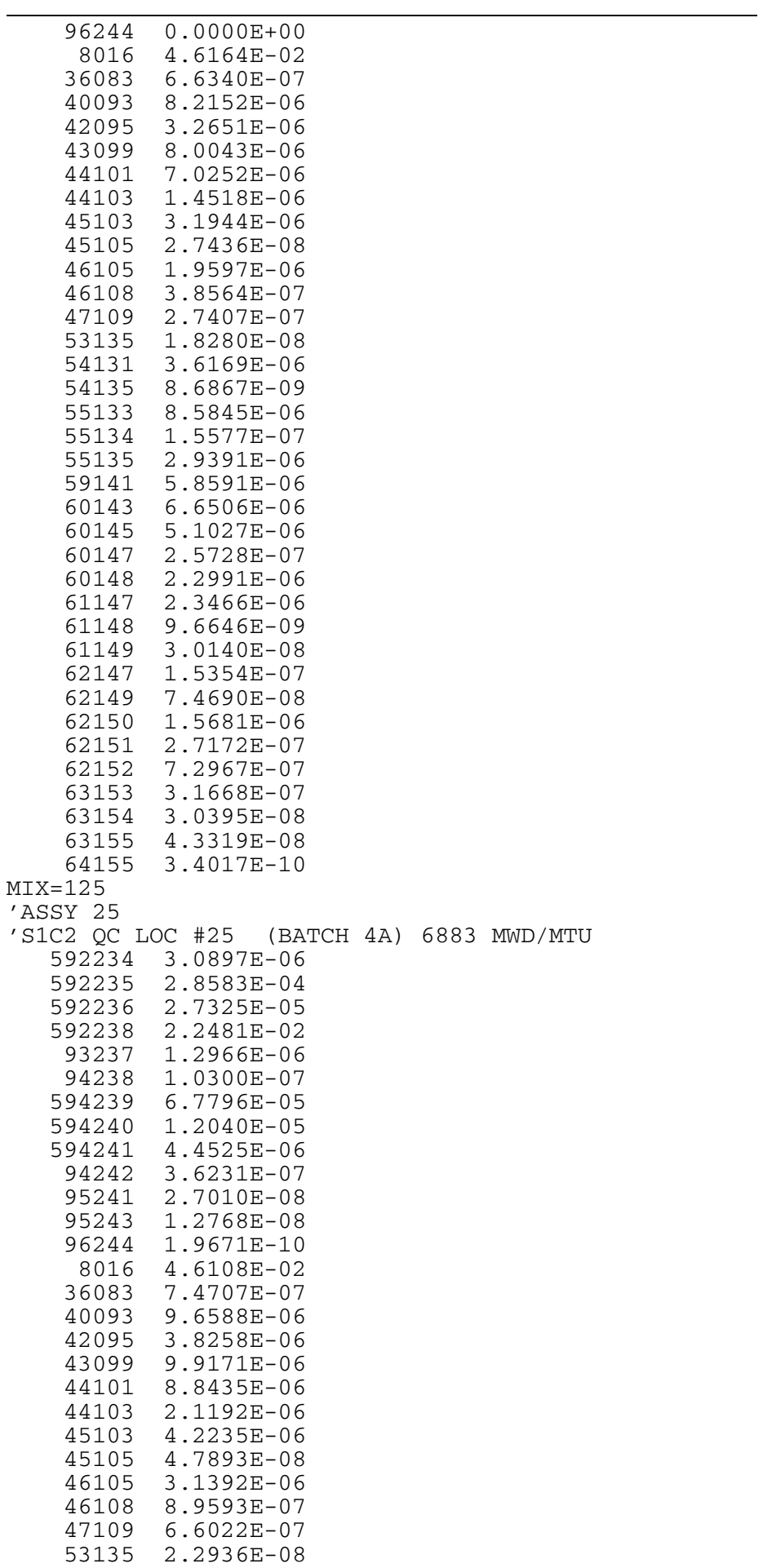


159

Table E.8. (continued)

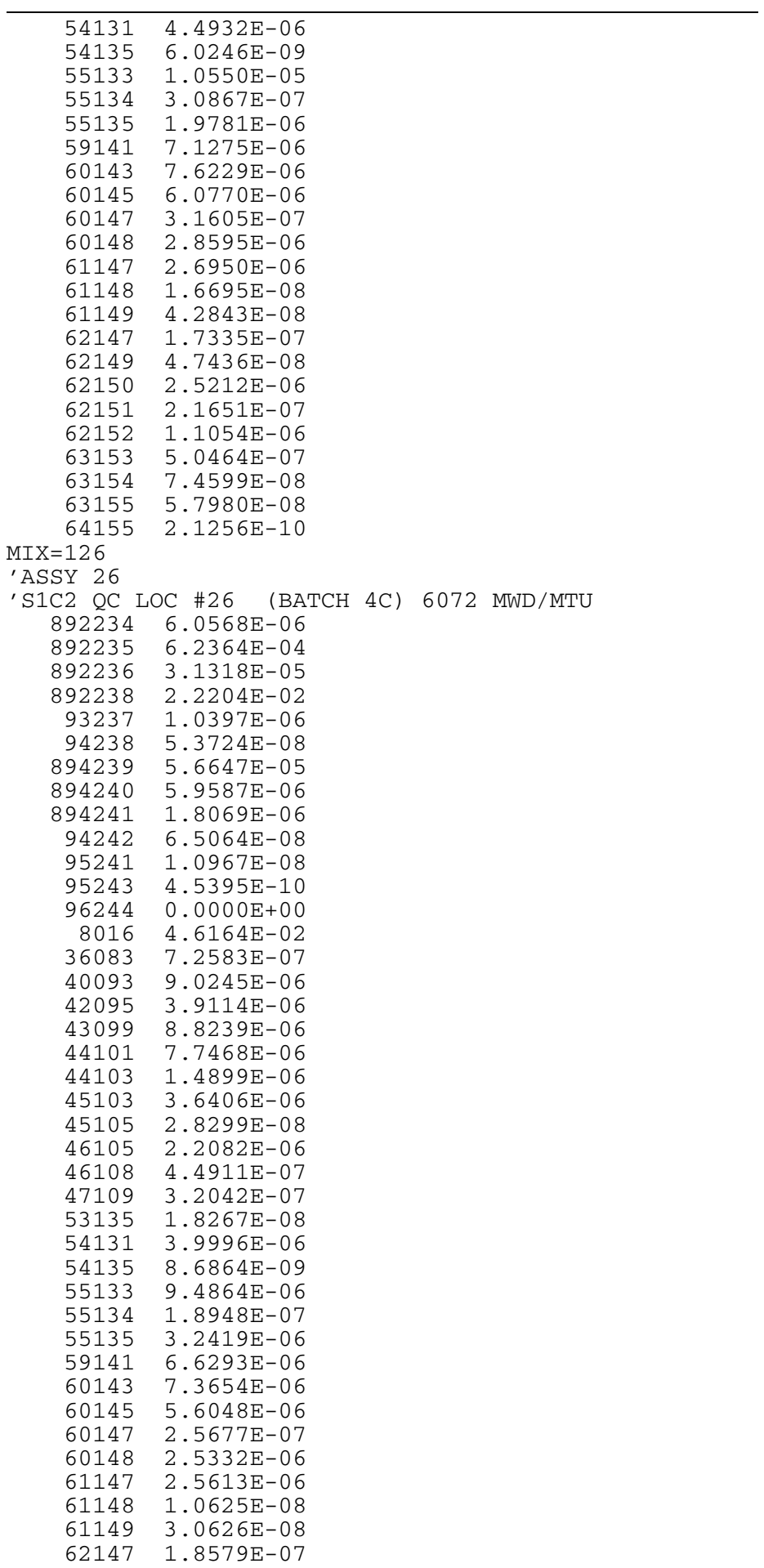


Table E.8. (continued)

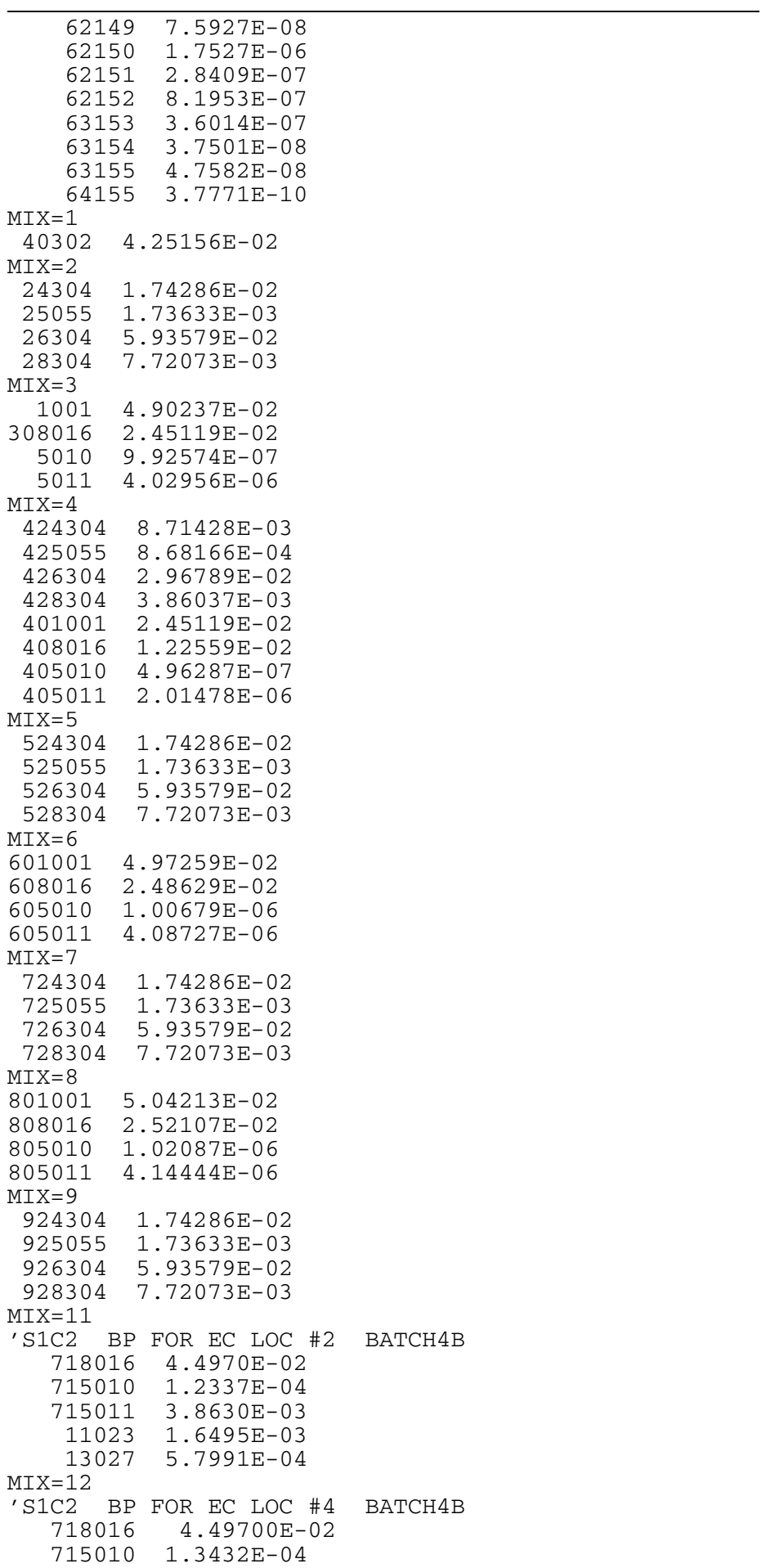


161

Table E.8. (continued)

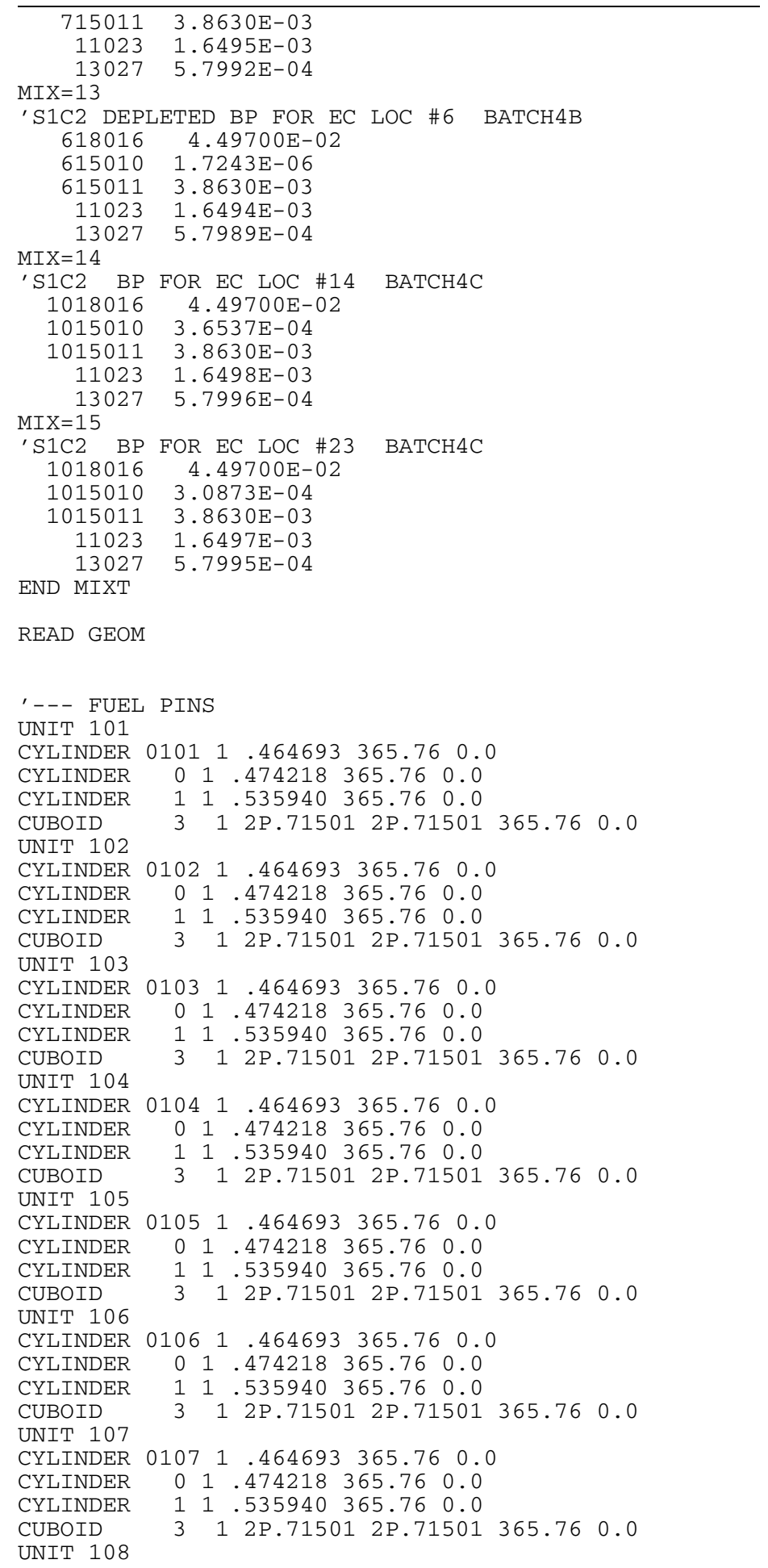


Table E.8. (continued)

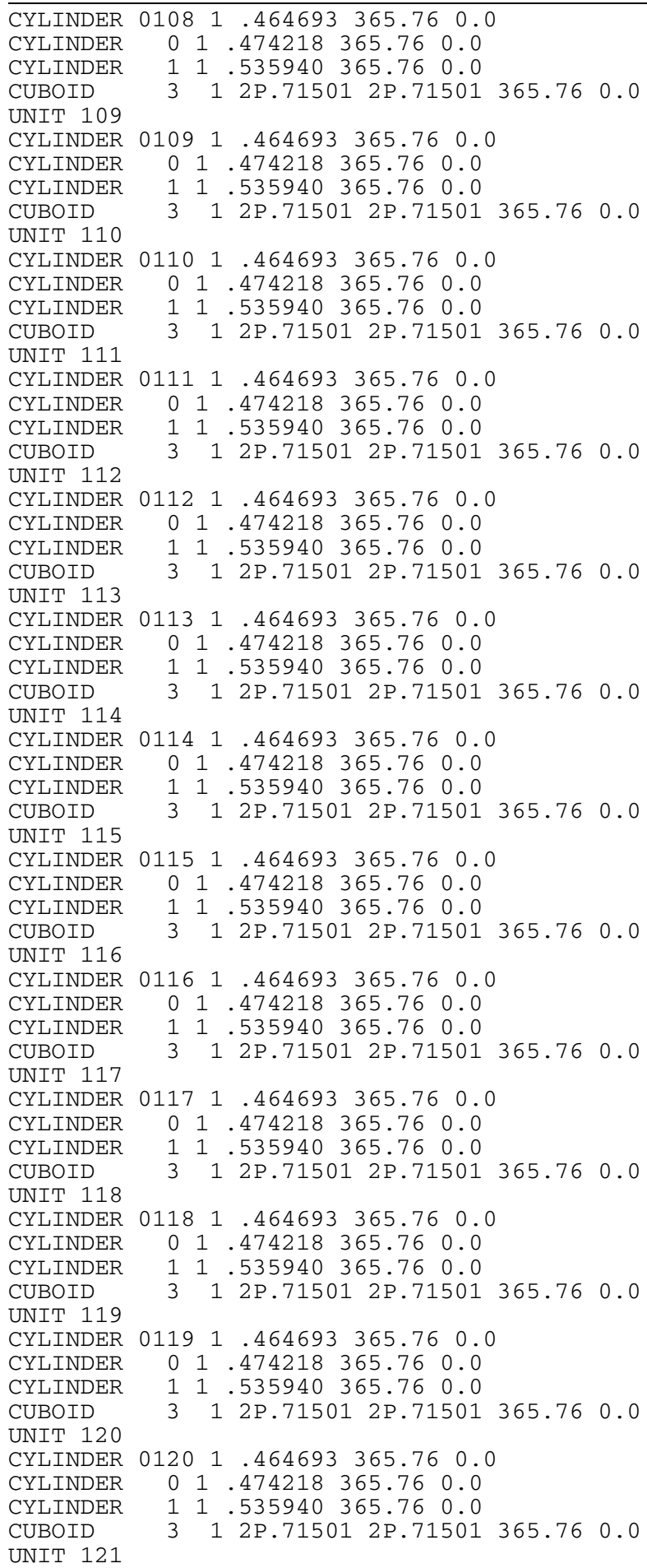


Table E.8. (continued)

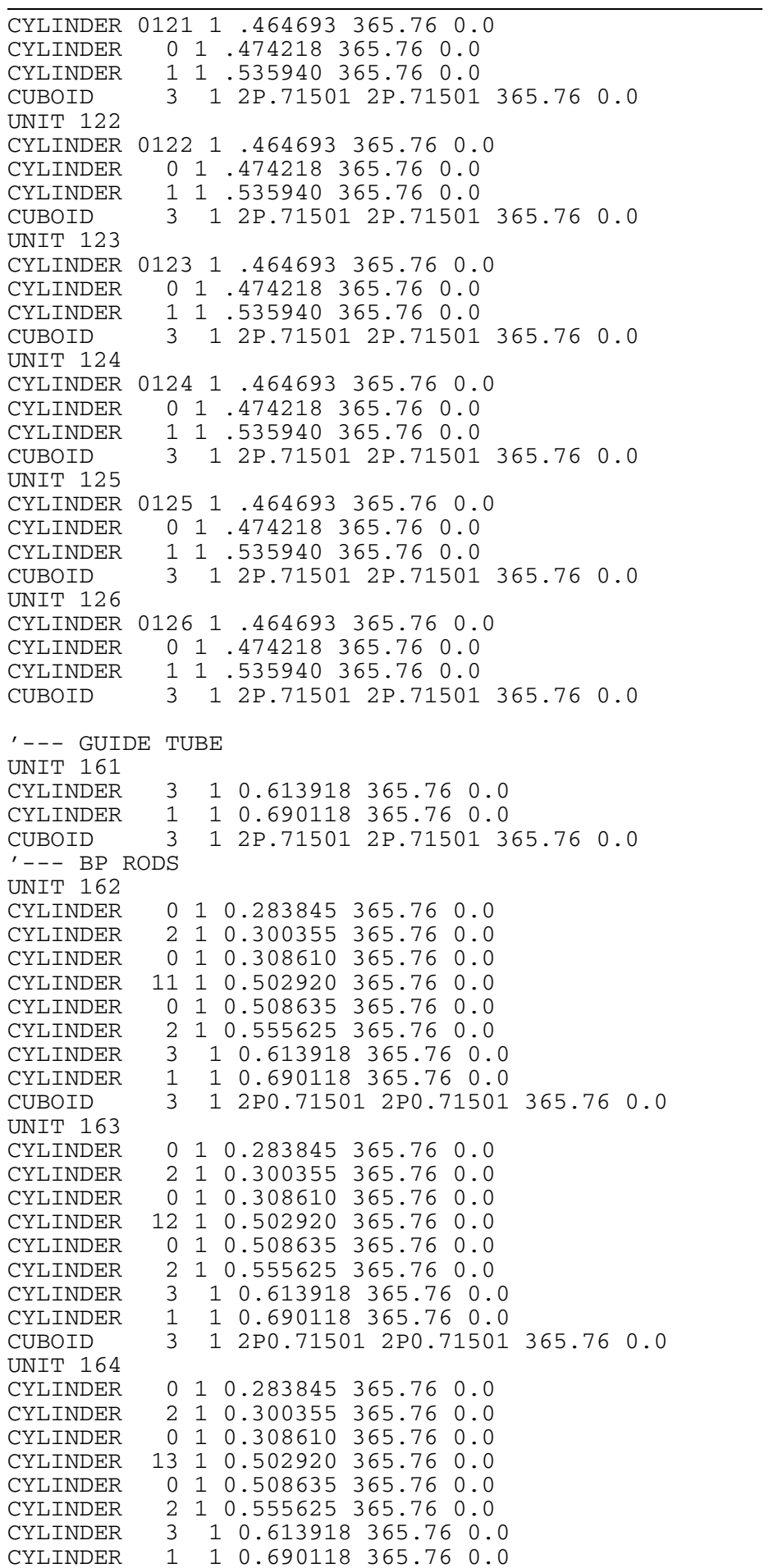


Table E.8. (continued)

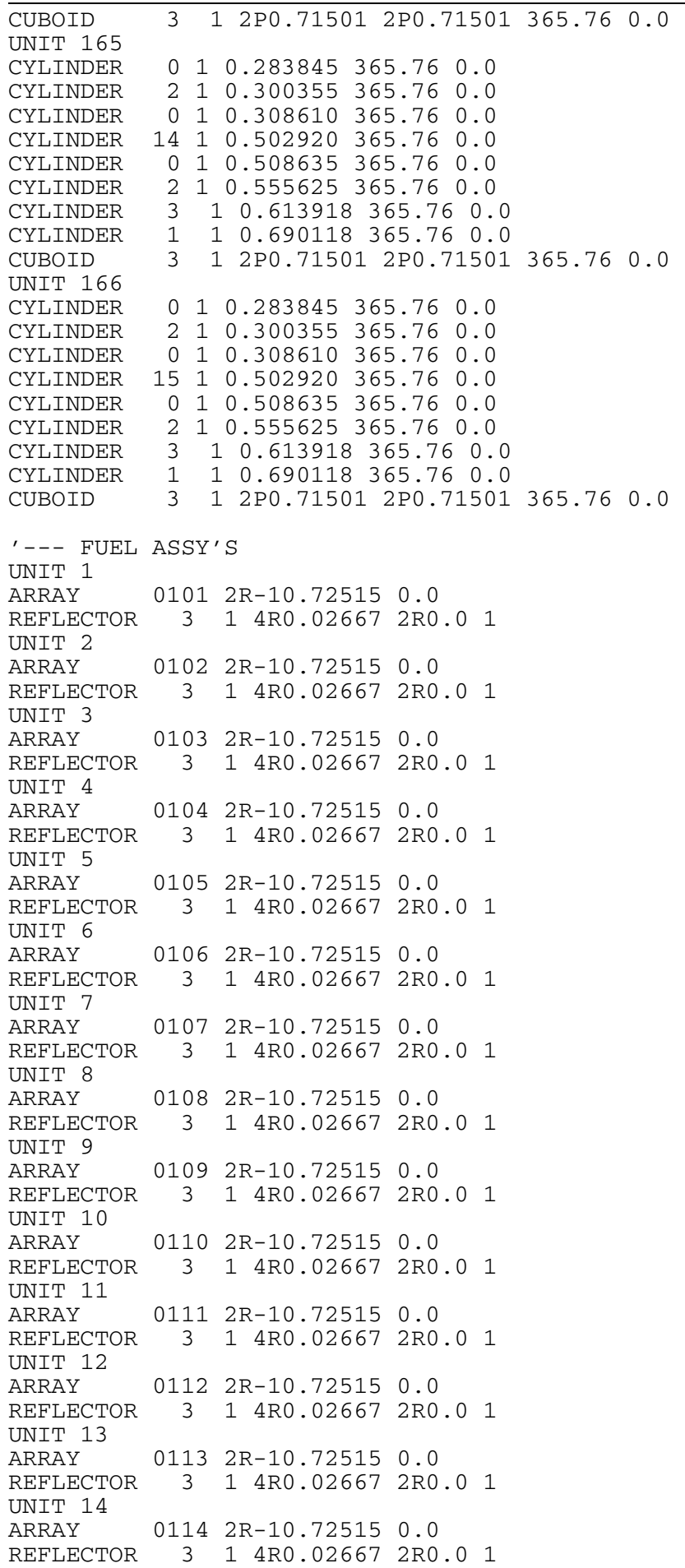


Table E.8. (continued)

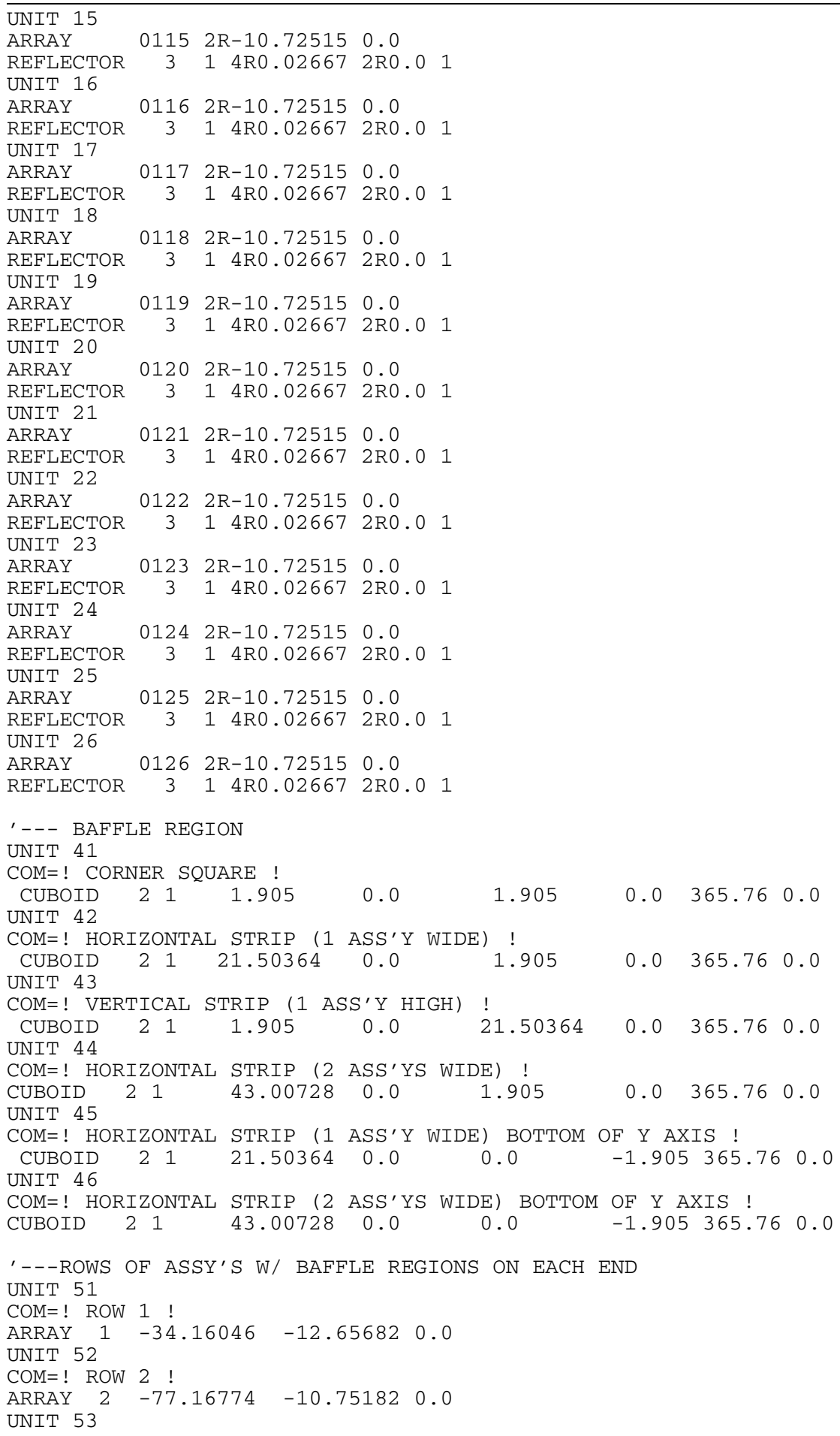


Table E.8. (continued)

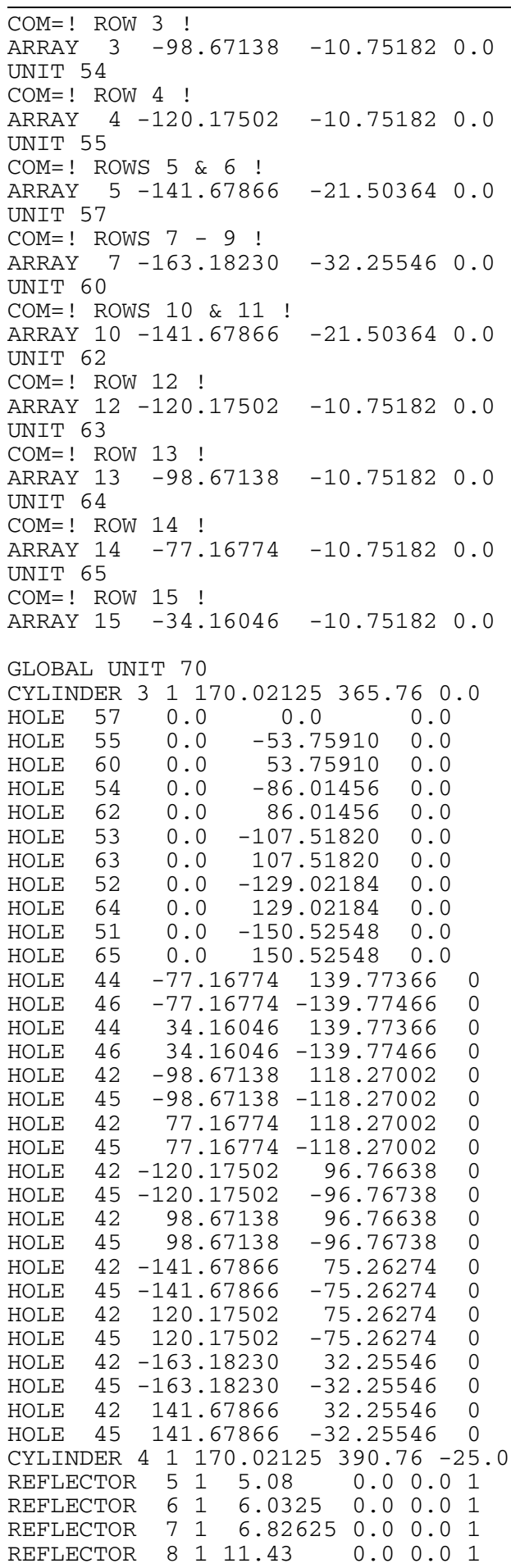


Table E.8. (continued)

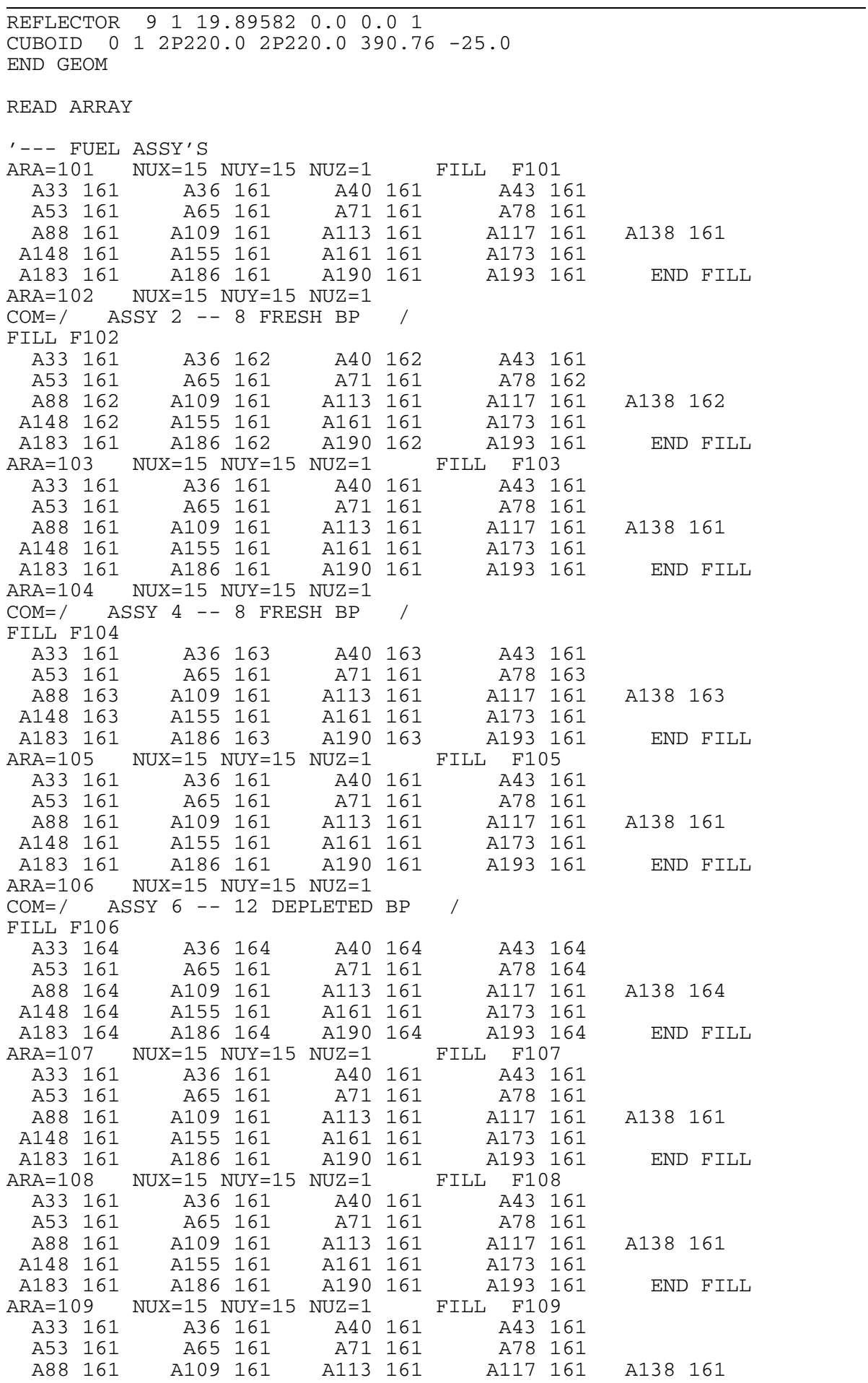


Table E.8. (continued)

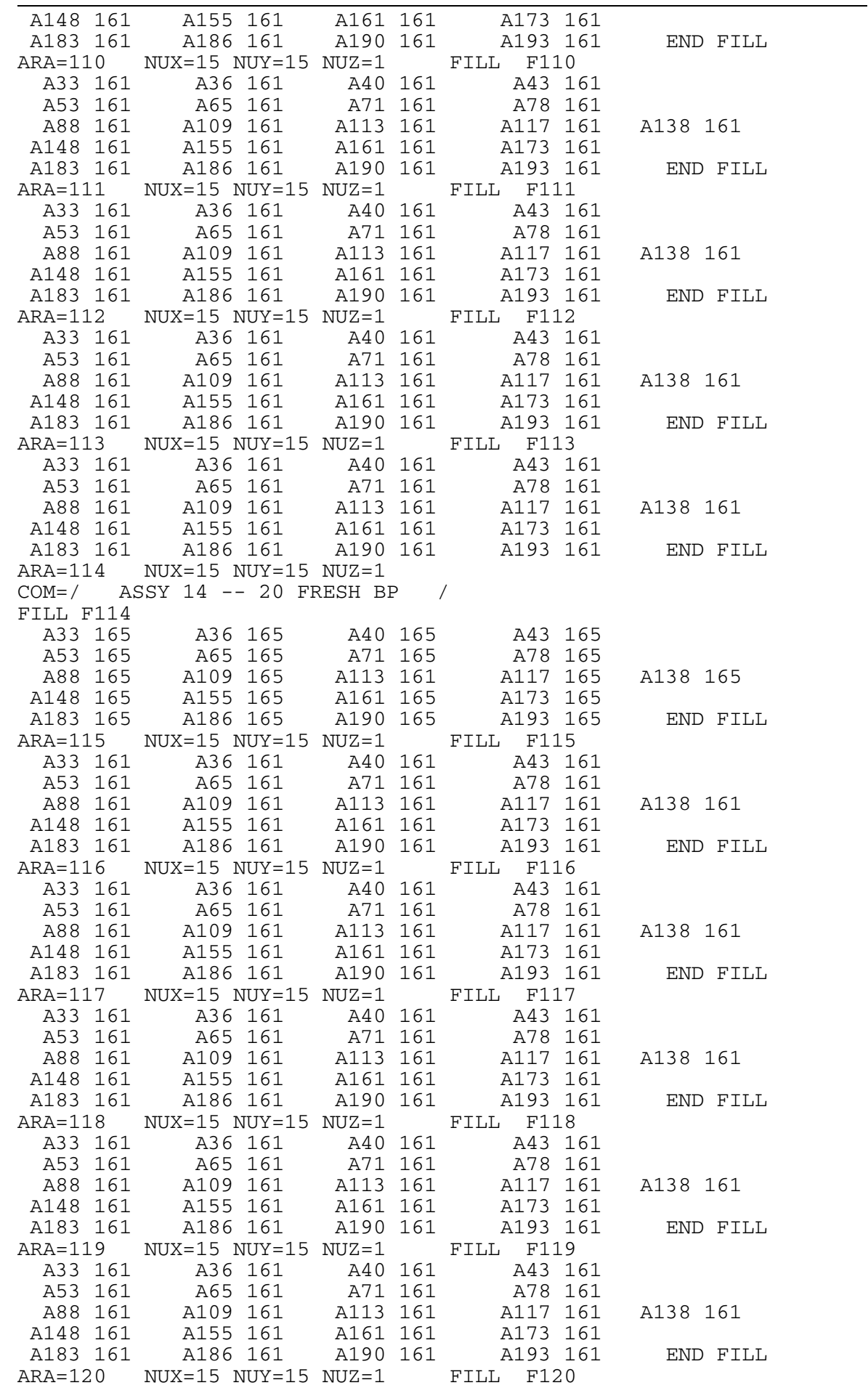


Table E.8. (continued)

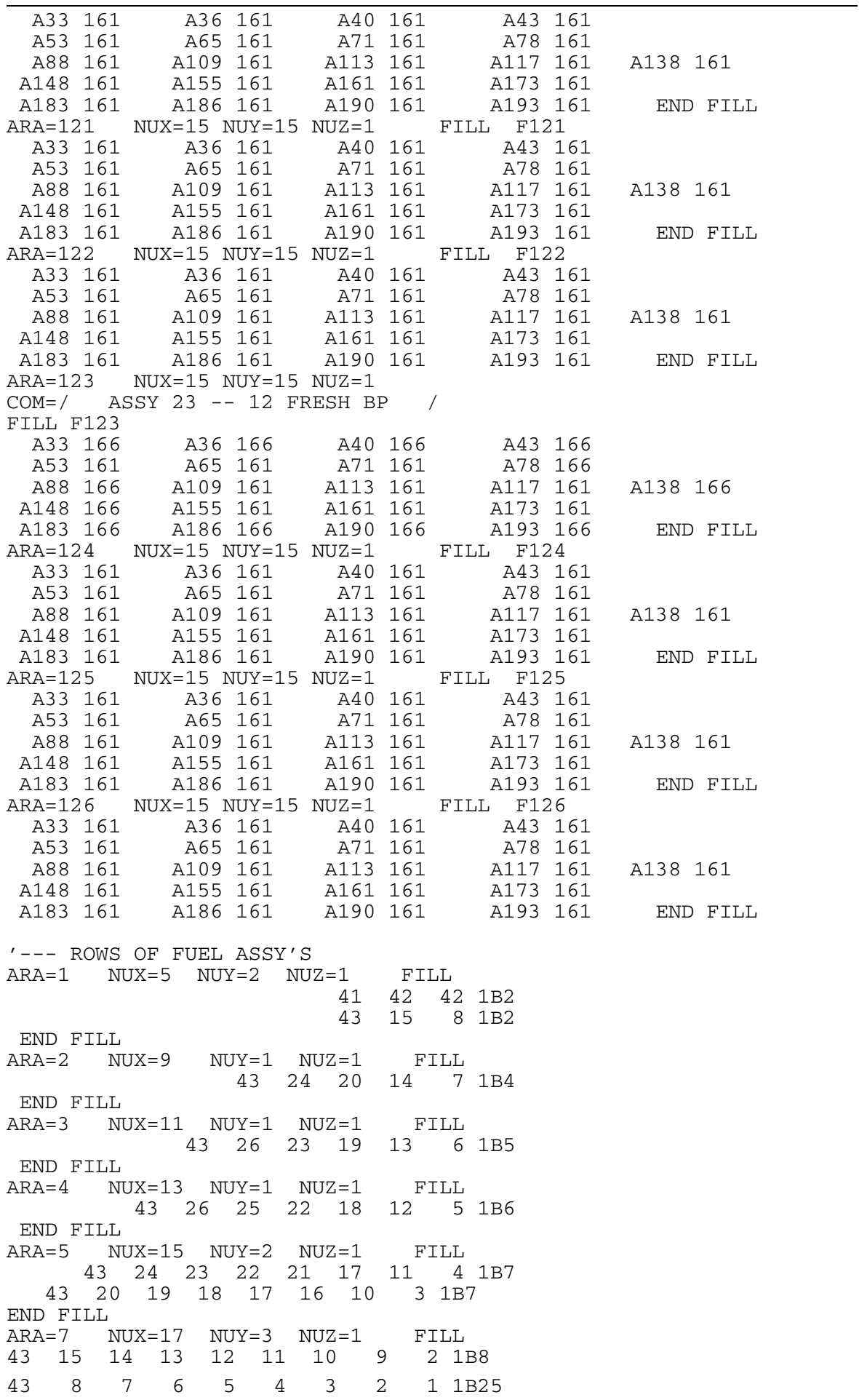


Table E.8. (continued)

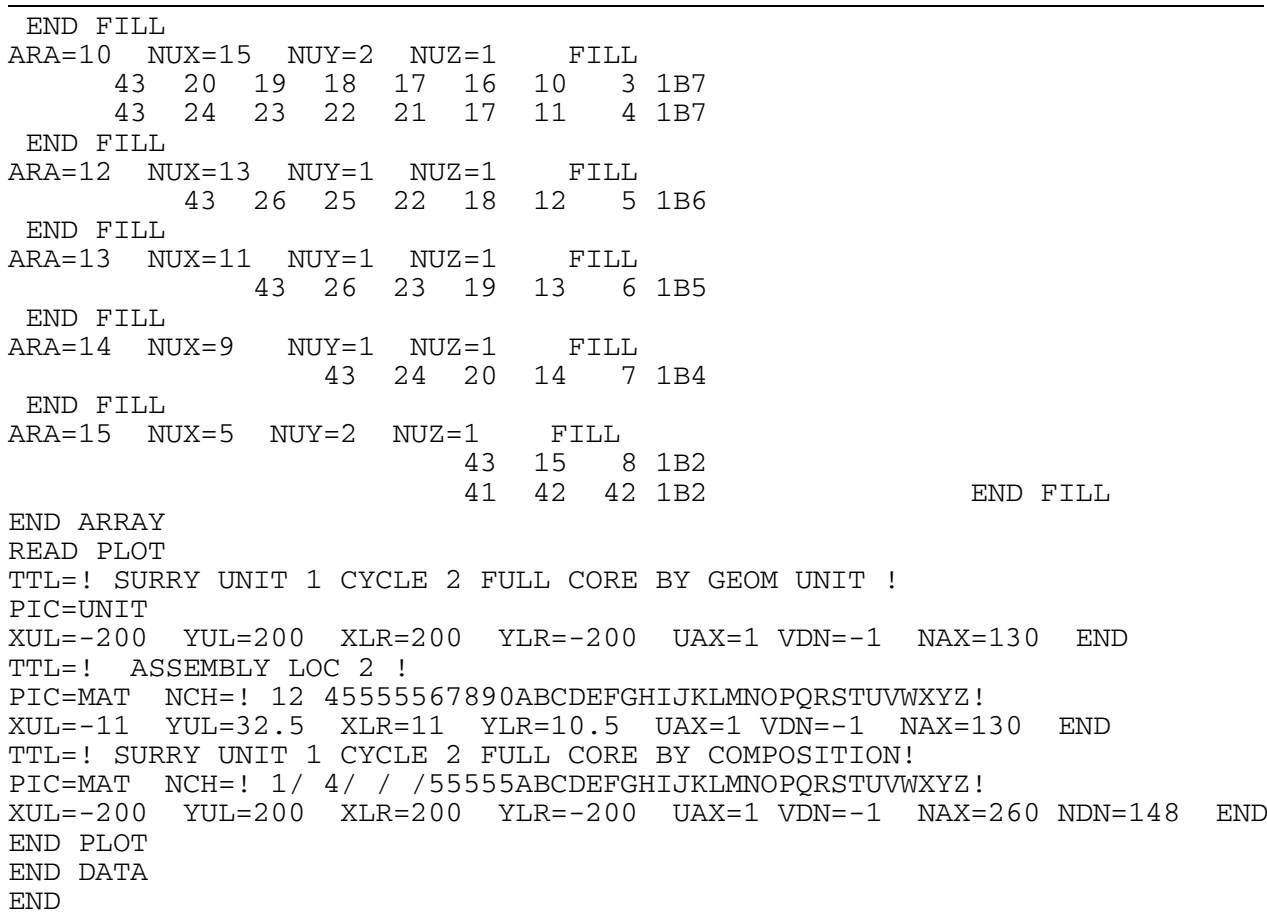


ORNL/TM-12294/V3

\section{INTERNAL DISTRIBUTION}

1. C. W. Alexander

2-3. S. M. Bowman

4. B. L. Broadhead

5. J. A. Bucholz

6. R. D. Dabbs

7-8. M. D. DeHart

9. M. B. Emmett

10. N. M. Greene

11. O. W. Hermann

12. M. Kuliasha

13. L. C. Leal

14. S. B. Ludwig

15. S. K. Martin

16. G. E. Michaels

17. B. D. Murphy

18-22. L. F. Norris

23. J. V. Pace
24-28. C. V. Parks
29. L. M. Petrie
30. R. T. Primm
31. J.-P. Renier
32. J. W. Roddy
33. R. W. Roussin
34. J. C. Ryman
35. C. H. Shappert
36. R. M. Westfall
37. B. A. Worley
38. R. Q. Wright
39-40. Laboratory Records Dept.
41. Laboratory Records, ORNL-RC
Document Reference Section
42. ORNL Y-12 Research Library
43. Central Research Library
44. ORNL Patent Section

\section{EXTERNAL DISTRIBUTION}

45. R. Anderson, General Nuclear Systems, Inc., 220 Stoneridge Dr., Columbia, SC 29210

46. M. G. Bailey, Office of Nuclear Material Safety \& Safeguards, U.S. Nuclear Regulatory Commission, MS TWFN 8F5, Washington, DC 20555

47. L. Barrett, Office of Civilian Radioactive Waste Management, RW-232 20545, U.S. Department of Energy, Washington, DC 20545

48. P. Baylor, Office of Civilian Radioactive Waste Management, RW-36, U.S. Department of Energy, Washington, DC 20545

49. C. J. Benson, Bettis Atomic Power Laboratory, P.O. Box 79, West Mifflin, PA 15122

50. J. Bickel, U.S. Department of Energy, Albuquerque Operations Office, P.O. Box 5400, Albuquerque, NM 87115

51. L. Blalock, U.S. Department of Energy, M-261 Quince Orchard, Washington, DC 20585-0002

52. J. Boshoven, GA Technologies, Inc., P.O. Box 85608, 10955 John J. Hopkins Dr., San Diego, CA 92121

53. M. C. Brady, Sandia National Laboratories, 101 Convention Center Drive, Suite 880, Las Vegas, NV 89109

54. P. Bunton, U.S. Department of Energy, RW-1, Washington, DC 20545

55. R. J. Cacciapouti, Yankee Atomic Electric Co., 1617 Worcester Rd., Framington, MA 01701

56. R. Carlson, Lawrence Livermore National Laboratory, P.O. Box 808, Livermore, CA 94550

57. C. R. Chappell, U.S. Nuclear Regulatory Commission, Office of Nuclear Materials Safety and Safeguards, TWFN 8F5, Washington, DC 20555

58. J. S. Choi, Lawrence Livermore National Laboratory, P.O. Box 808, Livermore, CA 94550

59. J. Clark, 2650 Park Tower Drive, Suite 800, Vienna, VA 22180

60. J. Conde, Consejo de Seguridad Nuclear, Justo Dorado, 11, 28040 Madrid, Spain 
61. D. R. Conners, Bettis Atomic Power Laboratory, P.O. Box 79, West Mifflin, PA 15122

62. M. Conroy, U.S. Department of Energy, M-261 Quince Orchard, Washington, DC 20585-0002

63. P. J. Cooper, Sandia National Laboratories, P.O. Box 5800, Albuquerque, NM 87185-0716

64. W. Davidson, Los Alamos National Laboratory, Group A4, MSF-611, Los Alamos, NM 87845

65-67. F. J. Davis, Sandia National Laboratories, P.O. Box 5800, Div. 6302, MS 1333, Albuquerque, NM 87185-0716

68. D. Dawson, Transnuclear, Inc., 2 Skyline Dr., Hawthorne, NY 10532-2120

69. T. W. Doering, TESS, B\&W Fuel Co., MS 423, Suite 527, P.O. Box 98608, 101 Convention Center Drive, Las Vegas, NV 89109

70. R. Doman, Nuclear Packaging, Inc., 1010 S. 336th St., Suite 220, Federal Way, WA 98003

71. E. Easton, U.S. Nuclear Regulatory Commission, Office of Nuclear Materials Safety and Safeguards, Washington, DC 20555

72. R. C. Ewing, Sandia National Laboratories, P.O. Box 5800, Div. 6643, MS 0716, Albuquerque, NM 87185-0716

73. C. Garcia, U.S. Department of Energy, Albuquerque Operations Office, P.O. Box 5400, Albuquerque, NM 87115

74. S. Hanauer, U.S. Department of Energy, RW-22, Washington, DC 20545

75. C. Haughney, U.S. Nuclear Regulatory Commission, Office of Nuclear Materials Safety and Safeguards, TWFN 8F5, Washington, DC 20555

76. L. Hassler, Babcock \& Wilcox, P.O. Box 10935, Lynchburg, VA 24506-0935

77. E. Johnson, E. R. Johnson Associates, Inc., 9302 Lee Hwy, Suite 200, Fairfax, VA 22031

78. R. Kelleher, International Atomic Energy Agency, Division of Publications, Wagramerstrasse 5, P.O. Box 100, Vienna, Austria A-1400

79. R. Kidman, Los Alamos National Laboratory, Group A4, MSF-611, Los Alamos, NM 87845

80. C. Kouts, Office of Civilian Radioactive Waste Management, RW-36, U.S. Department of Energy, Washington, DC 20545

81. S. Kraft, Nuclear Energy Institute, 1776 I Street, Suite 400, Washington, DC 20086

82. P. Krishna, TRW Environmental Safety Systems, 600 Maryland Ave. S.W., Suite 695, Washington, DC 20024

83. A. Kubo, 2650 Park Tower Drive, Suite 800, Vienna, VA 22180

84. W. H. Lake, Office of Civilian Radioactive Waste Management, U.S. Department of Energy, RW46, Washington, DC 20585

85-87. R. Lambert, Electric Power Research Institute, 3412 Hillview Ave., Palo Alto, CA 94304

88-90. D. Lancaster, 2650 Park Tower Drive, Suite 800, Vienna, VA 22180

91. D. Langstaff, U.S. Department of Energy, Richland Operations Office, P.O. Box 550, Richland, WA 99352

92. D. Lillian, U.S. Department of Energy, M-261 Quince Orchard, Washington, DC 20585-0002

93. C. Marotta, 1504 Columbia Ave., Rockville, MD 20850

94. M. Mason, Transnuclear, Two Skyline Drive, Hawthorne, NY 10532-2120

95. J. Massey, Sierra Nuclear Corporation, 5619 Scotts Valley Drive, Number 240, Scotts Valley, CA 95066

96. W. Mings, U.S. Department of Energy, Idaho Operations Office, 550 2nd St., Idaho Falls, ID 83401

97. A. Mobashevan, Roy F. Weston, Inc., 955 L'Enfant Plaza, SW, 8th Floor, Washington, DC 20024

98. R. Morgan, 2650 Park Tower Drive, Suite 800, Vienna, VA 22180

99. P. K. Nair, Manager, Engineered Barrier System, Center for Nuclear Waste Regulatory Analyses, Southwest Research Institute, 6220 Culebra Road, San Antonio, TX 78238-5166 
100. D. Napolitano, Nuclear Assurance Corp., 5720 Peachtree Parkway, Norcross, GA 30092

101. C. W. Nilsen, Office of Nuclear Material Safety and Safeguards, U.S. Nuclear Regulatory Commission, MS TWFN-9F29, Washington, DC 20555

102. D. J. Nolan, 2650 Park Tower Drive, Suite 800, Vienna, VA 22180

103-104. Office of Scientific and Technical Information, U.S. Department of Energy, P.O. Box 62, Oak Ridge, TN 37831

105. Office of the Assistant Manager for Energy Research and Development, Department of Energy Oak Ridge Operations (DOE-ORO), P.O. Box 2008, Oak Ridge, TN 37831

106. C. E. Olson, Sandia National Laboratories, P.O. Box 5800, Div. 6631, MS 0715, Albuquerque, NM 87185-0716

107. N. Osgood, U.S. Nuclear Regulatory Commission, Office of Nuclear Materials Safety and Safeguards, TWFN 8F5, Washington, DC 20555

108. O. Ozer, Electric Power Research Institute, 3412 Hillview Ave., Palo Alto, CA 94304

109. P. Pacquin, General Nuclear Systems, Inc., 220 Stoneridge Dr., Columbia, SC 29210

110. T. Parish, Department of Nuclear Engineering, Texas A \& M University, College Station, TX 77843-3313

111-113. M. Rahimi, 2650 Park Tower Drive, Suite 800, Vienna, VA 22180

114. B. Rasmussen, Duke Power Co., P.O. Box 33189, Charlotte, NC 28242

115. T. L. Sanders, Sandia National Laboratories, P.O. Box 5800, Div. 6609, MS 0720, Albuquerque, NM 87185-0716

116. K. D. Seager, Sandia National Laboratories, P.O. Box 5800, Div. 6643, MS 0716, Albuquerque, NM 87185-0716

117. M. Smith, U.S. Department of Energy, Yucca Mountain Project Office, 101 Convention Center Dr., Las Vegas, NV 89190

118. M. Smith, Virginia Power Co., P.O. Box 2666, Richmond, VA 23261

119. K. B. Sorenson, Sandia National Laboratories, P.O. Box 5800, Div. 6643, MS 0716, Albuquerque, NM 87185-0716

120. F. C. Sturz, Office of Nuclear Material Safety \& Safeguards, U.S. Nuclear Regulatory Commission, MS TWFN 8F5, Washington, DC 20555

121. J. Sun, Florida Power \& Light Co., P.O. Box 029100, Miami, FL 33102

122. T. Suto, Power Reactor and Nuclear Fuel Development Corp., 1-9-13, Akasaka, Minato-Ku,, Tokyo, Japan

123. R. J. Talbert, Battelle Pacific Northwest Laboratory, P.O. Box 999, Richland, WA 99352

124. T. Taylor, INEL, P.O. Box 4000, MS 3428, Idaho Falls, ID 83403

125. B. Thomas, VECTRA Technologies, Inc., 6203 San Ignacio Ave., Suite 100, San Jose, CA 95119

126. D. A. Thomas, B\&W Fuel Co., 101 Convention Center Drive, Suite 527, MS 423, Las Vegas, NV 89109

127. J. R. Thornton, TRW Enviornmental Safety Systems, 2650 Park Tower Dr., Suite 800, Vienna, VA 22180

128. G. Walden, Duke Power Co., P.O. Box 33189, Charlotte, NC 28242

129. M. E. Wangler, U.S. Department of Energy, EH-33.2, Washington, DC 20585-0002

130. R. Weller, U.S. Nuclear Regulatory Commission, TWFN 7J9, Washington, DC 20555

131. A. Wells, 2846 Peachtree Walk, Duluth, GA 30136

132. W. Weyer, Wissenschaftlich-Technische Ingenieurberatung GMBH, Mozartstrasse 13, 5177 TitzRodingen, Federal Republic of Germany

133. B. H. White, Office of Nuclear Material Safety \& Safeguards, U.S. Nuclear Regulatory Commission, MS TWFN 8F5, Washington, DC 20555

134. J. Williams, Office of Civilian Radioactive Waste Management, U.S. Department of Energy, RW46, Washington, DC 20545 
135. M. L. Williams, LSU Nuclear Science Center, Baton Rouge, LA 70803

136. C. J. Withee, Office of Nuclear Material Safety \& Safeguards, U.S. Nuclear Regulatory Commission, MS TWFN 8F5, Washington, DC 20555

137. R. Yang, Electric Power Research Institute, 3412 Hillview Ave., Palo Alto, CA 94304 